Conflicts over Natural Resources in the Global South - Conceptual Approaches 



\section{Conflicts over Natural Resources in the Global South - Conceptual Approaches}

\section{Maarten Bavinck}

Department of Geography, Planning and International Development Studies, University of Amsterdam, The Netherlands

\section{Lorenzo Pellegrini}

International Institute of Social Studies, Erasmus University Rotterdam, The Netherlands

\section{Erik Mostert}

Faculty of Civil Engineering \& Geosciences, Delft University of Technology, The Netherlands

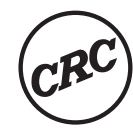


CRC Press/Balkema is an imprint of the Taylor \& Francis Group, an informa business (C) 2014 Taylor \& Francis Group, London, UK

Typeset by MPS Limited, Chennai, India Printed and Bound by CPI Group (UK) Ltd, Croydon, CRO 4YY

All rights reserved. No part of this publication or the information contained herein may be reproduced, stored in a retrieval system, or transmitted in any form or by any means, electronic, mechanical, by photocopying, recording or otherwise, without written prior permission from the publisher.

Although all care is taken to ensure integrity and the quality of this publication and the information herein, no responsibility is assumed by the publishers nor the author for any damage to the property or persons as a result of operation or use of this publication and/or the information contained herein.

Library of Congress Cataloging-in-Publication Data

Applied for

Published by: CRC Press/Balkema

P.O. Box I I320, 230 I EH Leiden, The Netherlands

e-mail:Pub.NL@taylorandfrancis.com

www.crcpress.com - www.taylorandfrancis.com

ISBN: 978- I-I 38-02040-5 (Hbk)

ISBN: 978-I-3I5-77846-4 (eBook PDF) 


\section{Table of contents}

Acknowledgements $\quad$ ix

List of Contributors $\quad$ xi

I Introduction I

MAARTEN BAVINCK, ERIK MOSTERT AND LORENZO PELLEGRINI

1.1 Preliminary remarks 1

1.2 The compendium of cases 2

1.3 Situating the cases 4

1.4 Taking action $\quad 8$

1.5 Ways forward 9

2 Conflict and cooperation on natural resources: Justifying the CoCooN programme

GEORG FRERKS, TON DIETZ AND PIETER VAN DER ZAAG

2.1 Introduction

2.2 Conflict and cooperation on natural resources: the academic debates

$\begin{array}{ll}2.2 .1 & \text { From old to new wars } \\ 2.2 .2 & 15\end{array}$

$\begin{array}{ll}\text { 2.2.2 Greed versus grievance } & 16\end{array}$

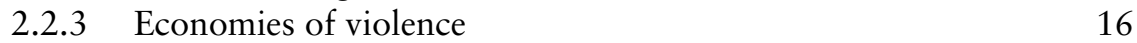

2.2.4 The present position: an emerging consensus 17

$\begin{array}{ll}\text { 2.2.5 Environmental peace building } & 19\end{array}$

$\begin{array}{ll}\text { 2.2.6 Livelihoods } & 20\end{array}$

$\begin{array}{ll}\text { 2.2.7 From scarcity to variability } & 21\end{array}$

$\begin{array}{lll}2.2 .8 & \text { Interdependence } & 21\end{array}$

2.3 Conflict and cooperation on natural resources: the policy perspective

2.3.1 International concerns $\quad 22$

$\begin{array}{ll}\text { 2.3.2 Dutch concerns } & 26\end{array}$

$\begin{array}{ll}\text { 2.3.3 Other approaches } & 27\end{array}$

2.4 Joining science and policy: The CoCooN initiative 28

2.4.1 CoCooN's understanding of conflict 28

2.4.2 Creating usable knowledge 29

$\begin{array}{lll}2.4 .3 \text { Objectives } & 29\end{array}$ 
3 New directions in conflict research from an economics perspective

SYED MANSOOB MURSHED

$\begin{array}{lll}3.1 & \text { Introduction } & 35\end{array}$

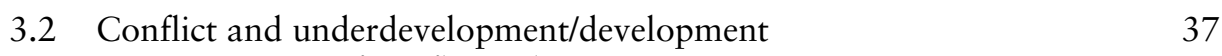

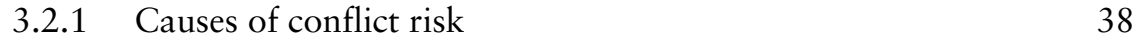

$\begin{array}{ll}3.2 .2 & \text { Social contract } \\ 3.2 .3 & 39\end{array}$

$\begin{array}{ll}\text { 3.2.3 Globalisation and conflict } & 40\end{array}$

$\begin{array}{lll}3.2 .4 & \text { Prosperity and violence } & 41\end{array}$

3.3 Natural resource endowments and civil war $\quad 42$

$\begin{array}{lll}3.4 & \text { Localised conflict } & 44\end{array}$

$\begin{array}{ll}3.5 & \text { Sectarian and civilisational conflict }\end{array}$

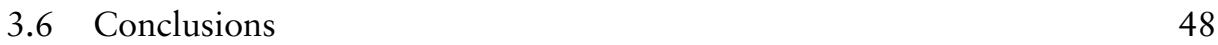

4 How natural is natural? Seeking conceptual clarity over natural resources and conflicts

MARCEL RUTTEN AND MOSES MWANGI

4.1 Introduction $\quad 51$

4.2 Lack of conceptual clarity 52

4.3 What are natural resources? a literature review 53

$\begin{array}{ll}4.4 & \text { What are conflicts? } \\ 48\end{array}$

4.5 African scholars and natural resource conflicts 58

4.6 Politics and natural resource conflicts: the EAPCC conflict case 63

4.7 The natural resources - conflicts framework 64

$\begin{array}{lll}4.8 & \text { Conclusion } & 68\end{array}$

5 Analysing the role of politics in groundwater management research in Ethiopia, Palestine and Yemen

EBEL SMIDT, TAYE ALEMAYEHU, ADEL AL WESHALI, KAREN ASSAF, ABDULLAH BABAQI, D. ABDEL GHAFOUR, ROZEMARIJN TER HORST, FRANK VAN STEENBERGEN, KIFLE WOLDEAREGAY AND OMAR ZAYED

$\begin{array}{lll}5.1 & \text { Introduction } & 72\end{array}$

5.2 Groundwater and management of commons $\quad 73$

5.3 Conflict and cooperation $\quad 75$

5.4 Case studies: groundwater management in Ethiopia, Palestine

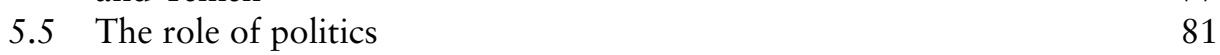

5.6 A typology of political states $\quad 82$

$\begin{array}{lll}5.7 & \text { Factors of change } & 83\end{array}$

5.8 Conclusion and discussion 86

6 Harms, crimes and natural resource exploitation: A green criminological and human rights perspective on land-use change

DAMIÁN ZAITCH, TIM BOEKHOUT VAN SOLINGE AND GUDRUN MÜLLER

$\begin{array}{lll}6.1 & \text { Introduction } & 91\end{array}$

6.2 Crime, harm and criminology 93

6.3 Green criminology 96 
6.4 The human rights-based perspective

6.5 The Colombian Cauca basin

101

6.6 The Brazilian Tapajós basin

102

6.7 Conclusion

104

7 Property rights, nationalisation and extractive industries in Bolivia and Ecuador

MURAT ARSEL, CARLOS MENA, LORENZO PELLEGRINI AND ISABELLA RADHUBER

7.1 Introduction

109

7.2 The left turn in Latin America

7.3 Nationalisation and property rights

7.4 Bolivia

114

7.4.1 Background

115

7.4.2 The current legal mining regime

116

7.4.3 A comparative analysis of legislations and legal decisions

7.4.4 Mines, ownership and the role of the state

7.5 Ecuador

7.5.1 A comparative analysis of the 2000 and 2009 mining acts

7.5.2 Mines and ownership

7.5.3 Mining and land ownership issues

7.6 Towards a theory of nationalisation and conflict in Bolivia and Ecuador

8 Engaging legal systems in small-scale gold mining conflicts in three South American countries

MARJO DE THEIJE, JUDITH KOLEN, MARIEKE HEEMSKERK, CELINE DUIJVES, MARIANA SARMIENTO, ALEXANDRA URÁN, INGRID LOZADA, HELCÍAS AYALA, JORGE PEREA AND ARMIN MATHIS

8.1 Introduction

8.2 Engaging legal systems

8.3 The case of Nieuw Koffiekamp (Suriname)

8.4 The case of Chocó (Colombia)

8.5 The case of Tapajós (Pará, Brazil)

8.6 Conclusion

9 Theorizing participatory governance in contexts of legal pluralism a conceptual reconnaissance of fishing conflicts and their resolution

MAARTEN BAVINCK, MERLE SOWMAN AND AJIT MENON

9.1 Introduction

9.2 A theoretical perspective on conflict and its resolution

9.3 Collective action and the origin of fishing law

9.4 Industrialisation, globalisation and the refashioning of governance

9.5 South Asia (Palk Bay)

9.6 South Africa

9.7 Comparative framework

9.8 Concluding remarks 
10 An analytical framework for assessing the impacts of Jatropha Curcas on Local Livelihoods

JOLEEN A. TIMKO

10.1 Introduction

173

$\begin{array}{ll}10.2 \text { The analytical framework } & 175\end{array}$

10.2.1 Local people are consulted about potential biofuel projects $\quad 178$

10.2.2 Impacts on local landholdings and land use are minimised 179

10.2.3 Household-level socio-economic impacts are addressed

10.3 What scope for reducing conflicts and enhancing cooperation on Jatropha-related projects?

\section{I Challenges in the design of a research and development} programme on conflict and cooperation over natural resources

JAN JOOST KESSLER, HAN VAN DIJK AND WIJNAND VAN IJSSEL

11.1 Introduction

11.2 Organisation, expectations and design principles

11.2.1 Organisation

11.2.2 Design of the programme

11.2.3 Definition of expectations and related design principles 


\section{Acknowledgements}

As in the case of all academic enterprises of this nature, we have incurred many debts while composing this volume. We are grateful first of all to The Netherlands Organisation for Scientific Research, Science for Global Development division (NWO/WOTRO), the Ministry of Foreign Affairs of The Netherlands and the CoCooN programme, which initiated seven projects in the field of conflict and cooperation over natural resources. The teams that are in charge of these research-cum-development projects have been our main source of inspiration and provided most of the contents of this volume.

The CoCooN Steering Committee and the International Programme Advisory Committee were enthusiastic about the idea of the volume from the very start and have made every effort to make it a reality. Kate Berry and Paul Hoebink deserve special mention for their help in reviewing the rough manuscript. The NWO Open Access Publication Fund contributed generously, thus affording readers in all continents access to the digital version of the book free of cost. Han van Dijk at NWO/WOTRO made the necessary arrangements for realising this publication, for which we are more than grateful.

We would like to thank our own departments - the Department of Human Geography, Planning and International Development Studies of the University of Amsterdam, the International Institute of Social Studies (ISS) of Erasmus University and the Department of Water Management of the Delft University of Technology - for affording us time to invest in the editorial process.

As an editorial team we are most grateful to our editorial assistant, Phil van der Krogt, who has done a magnificent job language-editing the various chapters and crafting a consistent whole. His contribution has been invaluable. And last but certainly not least, we would like to acknowledge Bart Schultz and Peter Stroo at UNESCOIHE, and Janjaap Blom and Lukas Goosen of CRC Press. They have done an excellent job in helping us finally get the book 'out there'.

Maarten Bavinck

Lorenzo Pellegrini

Erik Mostert 



\section{List of Contributors}

Taye Alemayehu is a $\mathrm{PhD}$ candidate at the Ethiopian Institute of Water Resources Addis Ababa University and serves as a consultant for Meta Meta. He has engaged in numbers of research activities and produced articles published by reputable journals. His key qualifications are in the areas of geological surveys and water resources.

Adel Al Weshali is Associated Professor and WEC Vice Director at Sana'a University Yemen. He teaches at the Faculty of Agriculture. His interest and specialization is in water technologies especially modern irrigation systems, water sustainable techniques and water resources management.

Karen Assaf works at the Arab Scientific Institute for Research and Transfer of Technology of Palestine. She has a Ph.D. in Environmental Science and Hydrology and has over three decades of experience in the water sector in Palestine, having worked at various universities, international and national non-governmental organizations, and within the Palestinian government. Her primary interest lies in the field of strategic planning and development.

Murat Arsel is Associate Professor of Environment and Development at the International Institute of Social Studies, Erasmus University Rotterdam. His areas of interest are the political ecology of environmental conflicts, state-society relations and development theory. In addition to his research on Latin America, he has worked extensively on environmental politics in Turkey.

Helcias Ayala is a Mining Engineer working in Chocó, Colombia on responsible mining. He participated in the formulation of ecological criteria and socio environmental programs such as Oro Verde. His interests encompass the ethnical dynamics and territorial organization of the black communities in Chocó and the Pacific.

Abdullah Babaqi is Professor of Chemistry at Sana'a University, Yemen, and has been the Director of the Water and Environment Center for several years. His major interest is water quality, pollution and Integrated Water Resources Management (IWRM).

Maarten Bavinck is co-founder and co-director of the Centre for Maritime Research (MARE), and has a long-time interest in fisheries governance issues. He has done extensive fieldwork on legal pluralism mainly in the fisheries of South Asia, and currently leads the REINCORPFISH project funded by CoCooN. He is author of the 
book Marine resource management - regulation and conflict in the fisheries of the Coromandel Coast, India, and co-editor of two books on fisheries governance. He now also serves as president of the Commission on Legal Pluralism.

Tim Boekhout van Solinge is assistant professor in criminology at the Willem Pompe Institute, Utrecht University. He has researched on drug use and policies in Europe, and since a few years he has moved into the field of green criminology, focusing on wildlife trade, and illegal timber trade in Indonesia and Brazil.

Ton Dietz is director of the African Studies Centre in Leiden and professor of African development at Leiden University. He is also guest professor human geography at the University of Amsterdam. His research interests are in political environmental geography, rural and agricultural development, impact of climate change, participatory evaluation of development and change, and land use change and conflicts. Ton Dietz chaired the NWO-WOTRO Steering Committee for CoCooN from its start until 2013.

Han van Dijk is a senior policy officer at WOTRO -Science for Global Development, which is a department of The Netherlands Organisation for Scientific Research (NWO). Building upon her socio-ecological background in science and development cooperation, she is presently responsible for funding programmes that link natural resources management with socio-economic development.

Celine Duijves is working in the fields of mining, community development and education. She obtained her MA degree in Cultural Anthropology in The Netherlands. She has been living in Suriname since 2008 and works as a consultant.

Georg Frerks holds a chair in Conflict Prevention and Conflict Management at Utrecht University and a chair in Disaster Studies at Wageningen University. Frerks served for nearly twenty years in the Dutch Foreign Service, both at headquarters and abroad. He also was head of the Conflict Research Unit of the Netherlands Institute of International Relations 'Clingendael'. As a sociologist and policy analyst he focuses on conflict and disaster-induced vulnerabilities and local responses as well as on policies and interventions implemented at international and national levels.

Abdel Ghafour is a principal hydrogeologist and water resources expert and researcher at the Palestinian Water Authority. He has more than 16 years of international experience in the field of water management. His interest is in the strategy development and practical implementation of water resource management plans. He is specialized in numerical models and water resource assessment and development.

Marieke Heemskerk is an anthropologist (PhD) with more than 15 years of experience conducting research in the small-scale mining sector, in Suriname and elsewhere. She is living and working as a consultant in Suriname.

Rozemarijn ter Horst is a consultant in water sector governance and project management operating for Ter H2orst: Water Projects. She specialises in the relation between (inter)national governance and local situations. Her focus is on conflict situations and water in the Middle East and (North) Africa. She also works on youth participation. 
Wijnand van IJssel studied tropical forestry. He spent 20 years living and working in countries in Africa, Asia and Latin America in the field of forestry, biodiversity conservation, environmental management and rural development. Since 2006 he works in the Netherlands at Foreign Affairs, responsible for the development of the knowledge and research agenda on food security and related private sector development.

Jan Joost Kessler received his $\mathrm{PhD}$ on the subject of integrating environmental issues into policy planning processes. He spent several years in countries in Africa and Asia and since then has been a consultant working with the not-for profit foundation Aidenvironment. His expertise is to support development agencies in policy and strategy development, evaluations and reviews in the themes of sustainable development and management of natural resources.

Judith Kolen works as a researcher at the Centre of Latin American Studies in Amsterdam, the Netherlands. She is a Cultural Anthropologist with research interests encompassing small-scale gold mining, identity, conflict, health and religion. She has done research in Suriname, Brazil and Ireland.

Ingrid Lozada is the Executive Director of Fundación Amigos del Chocó, Colombia. She is a Process Engineer with emphasis on industrial process. She has many years of experience in the development of entrepreneurial initiatives based on the alternative use of natural resources, as well as product differentiation schemes such as organic certifications, bio trate and fair trade.

Armin Mathis is professor at UFPA/NAEA Center for Advanced Amazon Studies at the Federal University of Pará, Belém, Brazil. He has a PhD in Political Science from the Free University of Berlin. His main areas of research involve the social organization of small-scale miners, working processes and public policy for small-scale mining.

Carlos F. Mena is professor in the School of Biological and Environmental Sciences at the Universidad San Francisco de Quito, Ecuador. He splits his research between the Ecuadorian Amazon, where he studies the impacts of oil and the drivers of land use change, and the Galapagos Islands, where he serves as the co-Director of the Galapagos Science Center.

Ajit Menon is a political scientist by training and interested primarily in the political economy of natural resource conflict. He is a co-author of the book Communitybased Natural Resource Management: Issues and Cases from South Asia. His current research includes work on identity and environmental politics in the Western Ghats of South India and conflict and cooperation in the Palk Bay fisheries of South Asia.

Erik Mostert is lecturer at the Department of Water Resources Management of the Delft University of Technology. His research focuses on transboundary water management, institutions for water management, and collaboration processes. Amongst others, he has advised the Dutch government on the collaboration structure for the Scheldt river and for the smaller German-Dutch boundary rivers.

Gudrun Müller is coordinator of FIAN International/Netherlands, based in Amasterdam. FIAN is an international human rights organization campaigning for 
the realization of the right to food. She is senior manager of different projects on land and water grabbing and their impact on economic, social and cultural human rights.

Syed Mansoob Murshed is Professor of the Economics of Conflict and Peace at the Institute of Social Studies in the Netherlands and is also Professor of Economics at Coventry University in the UK. He was the first holder of the rotating Prince Claus Chair in Development and Equity in 2003. He is the author of seven books and over 130 refereed journal papers and book chapters.

Moses Mwangi is a water engineer who has worked in many development projects and research programmes in eastern Africa, particularly in support of people in arid and semi-arid lands since the 1980s. His research interests include integrated water resource management and innovative water development and conflict mitigation. $\mathrm{He}$ lectures at South Eastern Kenya University, Kitui, Kenya.

Lorenzo Pellegrini is associate professor of environment and development economics at the Institute of Social Studies of Erasmus University Rotterdam. His research focuses on extractive industries, forest management, land reform and the issue of corruption. He has published on developing countries in general and on Latin America and Asia in particular.

Isabella M. Radhuber is a post-doctoral fellow at the Institute of Social Studies and Universidad San Francisco de Quito. She works on state transformation, plurinationality, political economy and natural resources mainly in Latin American countries, she has published widely on these topics.

Marcel Rutten is a geographer and has conducted longitudinal research on land, water, politics and food security in semi-arid Africa since the 1980s. On-going research is on natural resource conflicts, land acquisitions, and water innovation. Among his key publications are Selling Wealth to Buy Poverty (1992), Out for the Count (2001), Inside Poverty and Development in Africa (2008).

Mariana Sarmiento is a Colombian specialist in environmental policy analysis and design. Mariana holds a Masters in Environmental Management from Yale University, and a bachelor's degree from Tulane University in Environmental Studies and Political Science.

Ebel Smidt is a professional mediator and groundwater advisor and researcher at Delft University of Technology with thirty years of international experience. His interest is the interaction between science, policy development and practical implementation of water resources management. He is specialized in the resolution and prevention of conflicts in the water sector.

Merle Sowman has a $\mathrm{PhD}$ in integrated coastal management and is director of the Environmental Evaluation Unit at the University of Cape Town. Her key areas of interest are mainstreaming environmental sustainability issues into sector planning and decision-making processes, governance of coastal and small-scale fisheries systems, and facilititating community-university partnerships. Her recent publications include a co-edited volume entitled Governance for Justice and Environmental Sustainability Lessons Across Natural Resource Sectors in Sub-Saharan Africa. 
Frank van Steenbergen has worked in water management in different capacities from implementation to policy development (and back). He manages MetaMeta, a P3 company working, among others, on groundwater management.

Marjo de Theije is a Cultural Anthropologist $(\mathrm{PhD})$ working at the VU University and Centre for Latin American Research and Documentation (CEDLA) in The Netherlands, with many years of research experience on small-scale gold mining in the Amazon. She is the director of the GOMIAM research project on conflict and cooperation around small scale gold mining in the Amazon region.

Joleen Timko has been working in the field of forestry and studying forest-based livelihoods for over 15 years. She uses social science research methods to address local people's concerns over forest issues, primarily in Africa and with Canada's First Nations people.

Alexandra Uran is professor at the Anthropology Department of the University of Antioquia in Medellín, Colombia. She holds degrees in Mining Engineering and Environmental Anthropology and did her PhD in Sociology and Social Sciences in Germany, at Kassel Universität.

Kifle Woldearegay is a senior academic researcher at Mekelle University, Ethiopia. He is an engineering geologist with over twenty years of experience in site investigations for different engineering works including major surface and groundwater development projects for irrigation in Ethiopia. He has experience in the conjunctive use of surface and groundwater, and in evaluating hydrological effects of catchment based watershed management.

Pieter van der Zaag is professor of water resources management at the UNESCO-IHE Institute for Water Education, and at Delft University of Technology. He has special interests in agricultural water management, in water allocation issues in catchment areas and in the management of transboundary river basins, on which he has published widely. Pieter is fascinated by the dynamic relationship between biophysical and social processes when managing water, and in understanding patterns of cooperation over water.

Damián Zaitch is associate professor in criminology at the Willem Pompe Institute, Utrecht University. He has worked and published on organised crime, drug trafficking and drug policies in the Netherlands and Latin America. He is currently interested in new forms of cross-border transnational organised crime and on state-corporate crimes against the environment.

Omar Zayed is a principal geologist and hydrogeologist and water resources expert and researcher at the Palestinian Water Authority with international experience of 17 years. His interest lies in water resource monitoring and evaluation, and practical implementation of water resources management plans. He is specialized in monitoring and water resources assessment and development. 



\title{
Introduction
}

\author{
Maarten Bavinck, Erik Mostert \& Lorenzo Pellegrini
}

\begin{abstract}
This chapter provides an introduction to the volume on conflicts over natural resources in the Global South and situates the various contributions made. The authors note that such conflicts frequently involve poor, mainly rural people who are struggling to maintain access to the resources on which they depend for a living. The volume is concerned mainly with conceptual approaches to the issue of conflict. Given the diversity of conflict and cooperation dynamics and their relation with natural resources, the authors argue that general causal theories are problematic. Rather than aiming for grand explanations, the volume therefore is aimed to realise what Merton (1949) has termed 'middle-range theory'.
\end{abstract}

Keywords Natural resources, conflict, cooperation, Global South, poverty, governance.

\section{I.I PRELIMINARY REMARKS}

This book is primarily about the conflicts that often characterise the exploitation of natural resources. The focus is on poor, mainly rural, people and their struggles to maintain access to the resources on which they depend for a living, such as water, land, agriculture, fisheries and minerals. It is about the troubles that prevail and the ways in which people cooperate to resolve them, for better or worse.

Although poverty is a universal phenomenon, not limited to specific parts of the world (CIESIN 2006), it is the defining feature of the region known as the Global South. The countries that belong to the Global South are mostly located in Africa, Asia and Latin America, and a large part of their populations live in rural areas and is engaged in the primary sector. This means that they rely directly on the natural environment for their livelihood.

The effects of human development on the natural environment have been analysed globally in the Millennium Ecosystem Assessment (MEA) (2005). This report points to the human reliance on manifold ecosystem services. The present volume concentrates

\footnotetext{
${ }^{1}$ Department of Geography, Planning and International Development Studies, University of Amsterdam (Corresponding author: J.M.Bavinck@uva.nl)

${ }^{2}$ Faculty of Civil Engineering \& Geosciences, Delft University of Technology, Netherlands

${ }^{3}$ International Institute of Social Studies, Erasmus University Rotterdam, Netherlands
} 
on a particular kind of services, known as provisioning: services that provide people with goods essential for their livelihoods. The MEA notes that many of these services are degrading globally and therefore becoming increasingly scarce. This not only puts pressure on present but also on future generations and their opportunities for wellbeing.

Climate change adds a new dimension to the discourse on ecosystem services. Resilience and adaptation are the new buzzwords, drawing attention to the need for preparing societies for important changes in their climatological and physical surroundings. Importantly, attention is also being paid to the differential impact of climate change. As Adger et al. (2009: 11) point out, the debate is now also about "how adaptation must happen for the common good, coupled with assisting the most vulnerable." It is clear that resilience and adaptation processes are not necessarily conflict-free, and that, here again, some people are more likely to be side-lined than others.

The present volume finds its origin in an innovative research programme initiated by the Netherlands Organisation for Scientific Research (NWO/WOTRO) in collaboration with the Ministry of Foreign Affairs of the Netherlands. This programme, entitled 'Conflict and Cooperation over Natural Resources' (CoCooN), has three objectives: 1) to generate new knowledge, high quality research and innovation in the field of conflict and cooperation over natural resources; 2) to support policy development and practice in developing countries; and 3) to build up capacity at different levels. The seven projects that have been funded during the CoCooN programme (2010-2016) all follow a case study approach; they cover different geographical regions as well as a broad range of resources and resource issues. The project teams consist of academics and practitioners, and have a multi-disciplinary composition. More details on the rationale of the programme and how it was developed can be found in Kessler et al.'s concluding chapter, "Challenges in the design of a research and development programme on Conflict and Cooperation over Natural Resources" (Chapter 11).

The aim of this volume is to present the various conceptual approaches adhered to by each of the CoCooN projects. It therefore has a theoretical, rather than a practical ambit. The volume consists of three parts: theoretical overviews (Part 1), case studies (Part 2) and policy perspectives (Part 3). This chapter introduces the diverse contributions and situates them in the debate over natural resources and conflict. First, we describe the case study chapters, which constitute the core of the volume. Secondly, we turn to the theme of conflict and cooperation over natural resources, highlighting the debate as brought forth in the more general contributions to this volume. Thirdly, we discuss the action potential of the CoCooN programme.

\section{I.2 THE COMPENDIUM OF CASES}

The cases included in this volume capture a range of natural resources, geographical contexts, and conflict dynamics. The geographical scope is wide-ranging: three projects focus on Latin America, one on Asia, one on the Middle East, and two on Africa (with one project bridging two continents). The majority of cases are of a comparative nature, exploring experiences in multiple regions. The natural resources, on which the cases ultimately hinge, vary from land to minerals (oil, gold, marble and gypsum), biofuels (Jatropha) and fish. 
Chapter 4 by Rutten and Mwangi is rooted in a project on the reconciliation of competing claims in Kenya's dry land regions. Noting that concepts such as 'natural resources' and 'conflict' are frequently ill-defined, they consider the manner in which scholars, particularly in Africa, have addressed them. The assessment framework they formulate to understand the origins of conflict is rooted in historical analysis and political economy (cf. Peluso and Watts 2001; Sikor and Lund 2009). The framework is illustrated with an animated case study on conflicts over the mining of marble and gypsum (which is used for fabricating fertiliser and plaster) that involves representatives of various ethnic groups. The chapter shows that conflicts that seem straightforward are in fact intricately multi-layered and have a complex historical nature, in which power and various notions of justice are at play.

Chapter 5 by Smidt et al. focuses on the issue of groundwater exploitation as it plays out in three unique cases, the Palestinian Territories and Yemen in the MiddleEast and Ethiopia in the Horn of Africa. Both regions suffer from water scarcity as well as social strife, all of which increase the importance of the political domain for realising adequate water usage arrangements. The main aim of this particular chapter is to analyse, in a comparative perspective, the workings of the 'political black box' in a collection of state formations: democratic states, autocratic states, exclusive states (in which certain groups are systematically marginalised), and fragile states. The authors emphasise that conflict and cooperation are not mutually exclusive concepts, but that cooperation on minor issues can occur in a context of overarching conflict.

Chapter 6 by Zaitch et al. takes a green criminological perspective and applies this to the issue of land-use transformations in Colombia and Brazil. These include deforestation, the conversion of land to agro-fuel monocultures, the construction of mega-dams, and large-scale commercial mining. The authors argue that criminology offers inroads into understanding three interrelated issues. First, it allows for analysis of who the perpetrators are, how illegal mechanisms are constituted, and why illegal practices take place. Second, it reveals the victims and the social and environmental harms created by large-scale land-use transformations. Finally, it highlights the violation of 'rights', and the initiatives to guarantee, defend and enforce them. Events in the Tapajos Basin in Brazil and the Cauca Basin in Colombia provide illustrations of the approach, and of manners in which a reduction of harm can be realised. Overall, the criminological approach permits an analysis of the actors and the mechanisms at play when natural resources are (mis-)appropriated in manners that violate the de jure framework.

Chapter 7 by Arsel et al. concentrates on minerals in Bolivia and Ecuador and the impact of the nationalisation of extractive industries on the conflicts that mark the sector. The authors use a property rights framework to explore the changes that are taking place and highlight contradictions that exist in the regulatory framework. In both Bolivia and Ecuador change follows from the radical demands of indigenous communities and other groups. The authors argue that a theory of nationalisation needs to highlight continuities as well as breakages in the historical pattern. Moreover, nationalisation must be situated in the much broader political economy dynamics of the so-called Left Turn. The state is in this context not only the instigator of nationalisation, but is itself transformed in the process.

Like that of Arsel et al. (Chapter 7), De Theije et al.'s study (Chapter 8) is also situated in Latin America. De Theije et al., however, instead focus on one specific 
activity: small-scale gold mining in Surinam, Colombia and Brazil. Realising that state influence over these activities is frequently marginal and often distorted, and that parallel arrangements are frequently in place, the authors make use of a legal pluralism framework. The argument here is that the analysis of the interplay between legal systems in a given context contributes to knowledge on how conflicts develop over time. This framework also allows for the development of more appropriate policies that are relevant to and reflect the realities of the sector. The authors also highlight how an apparent situation of regulatory void, when analysed in depth, consists of numerous regulatory frameworks, each with a different degree of formalisation. When staking their claims over resources, the actors refer strategically to the various frameworks in view of current contingencies and with the purpose of furthering their own interests.

In chapter 9, Bavinck, Sowman and Menon shift attention from the land to the sea. They study fishing conflicts in two contrasting geographical regions: South Africa and South Asia. Although the parties to these conflicts and their historical precedents differ substantially, the authors argue that they can be analysed in a similar fashion. This chapter provides a framework for analysing governance processes 'from the bottom up' - that is, starting from the perspective of small-scale fishers. Here again the legal pluralism perspective provides good service. Over a time period of one hundred years, the fisheries in both regions have been impacted by the introduction of new technologies, globalisation and the fragmentation of law. Legal pluralism has complicated the fisheries picture and contributed to the exacerbation of conflict. In fact, 'new' regulatory regimes introduced by the state have failed to replace customary law, which maintains significant influence. The authors hold, however, that co-management and participatory governance provides opportunities for resolving conflicts over fisheries.

The final chapter in the case study section, authored by Timko (chapter 10), discusses the development of biofuel cropping in Ghana and Ethiopia and the conflicts that have since arisen. The sustainable livelihoods approach (Scoones 2009) constitutes her main source of inspiration, and the chapter's aim is to develop a framework by which local people can establish the potential impact of Jatropha cultivation, production and usage. Timko discusses three criteria that have been established through preliminary fieldwork as well as from the literature. The first criterion is whether local people are consulted and adequately informed about potential biofuel projects in their vicinity. Secondly, the impact on local landholdings and land use needs to be minimised. Thirdly, local livelihoods must benefit to the greatest extent possible from Jatropha cultivation. The author concludes that there is ample scope for reducing conflicts around Jatropha-related projects in ways that enhance local livelihoods, including those of women.

\section{I.3 SITUATING THE CASES}

Reasoned scrutiny (Sen 2009) starts with defining the concepts in question and most contributors to this volume would probably agree with Bavinck et al.'s (Chapter 9) minimal definition of conflict as "confrontations between groups or categories of people" regarding a resource activity and its management. Conflict in this sense may be positioned on a continuum ranging from mild tension to outright violence. Usually, however, the term is reserved for the more serious cases that preclude mutually 
beneficial cooperation, involve violence, or have a high potential of developing into such cases (Smidt et al., Chapter 5).

Conflicts in the sense of confrontations are related to, but differ from conflicts in the sense of conflicting interests. Conflicting interests may or may not lead to confrontations. For instance, if there is water scarcity, not all demands can be met and the different water users will have a conflict of interests. However, effective institutions may be in place that regulate and limit water use and facilitate peaceful relations. If problems nonetheless occur, formal or informal conflict resolution procedures may be used for resolving or containing the conflict and preventing escalation. Below we shall note that while institutions can help to contain conflict, they can also provoke it.

The word 'cooperation' derives from the Latin cooperatio, which means working together. Authors often add a qualification, working together "towards a common goal." Actors, however, may also work together if they have different goals (Gray 1989; Huxham and Vangen 2005). Cooperation is often seen as the opposite of conflict: the more cooperation there is, the less conflict there will be, and vice versa. Yet, conflicting interests do not exclude cooperation, and cooperation does not exclude conflicting relations. Basing themselves on Zeitoun (e.g. Zeitoun and Mirumachi 2008; Zeitoun, Mirumachi et al. 2010), Smidt et al. (Chapter 5) argue that formal agreements on relatively minor issues may be concluded without the root causes of the problem being addressed; hence the underlying conflict may actually persist.

It must be noted that we do not take a normative stance on conflict and acknowledge the functions that conflict can serve. After all, if the root causes of a problem are not addressed, cooperation may actually facilitate the perpetuation of injustice and legitimise the status quo. An overt conflict may be necessary to deal with these root causes. Kessler et al. (Chapter 11) refer to this as the 'positive functions' of conflict. Yet, as Georgescu Roegen (1975) has already noted, drawn out conflict is also a very wasteful process. While cooperation may benefit some more than others, conflict is generally costly for all parties concerned, especially for those who possess less power and fewer resources. Moreover, the outcomes of overt conflict are very uncertain. Considerations such as these may explain why some inhabitants of the Palestinian Territories are willing to cooperate on environmental matters with Israelis while others are not. Cooperation may, for example, result in short-term environmental and economic benefits, but it may also be seen as a 'normalisation' of the Israeli occupation of the West bank and Gaza strip. To complicate matters, within the Palestinian Territories, political opponents are often accused of being 'normalisers', in order to effectively discredit them. Thus the political costs of cooperation are increased (Abu Sarah 2011).

The contributions to this book make reference to a large number of potential causes of conflicts. These can be grouped under three headings: causes related to the resources themselves, causes having an origin in social tensions, and causes that follow from the failings of institutional frameworks. These categories are not mutually exclusive.

Frerks et al. (Chapter 2) highlight the fierce debate that surrounded the relationship between natural resources and conflict in the 1990s. This debate centred on the question of whether it was the scarcity or rather the abundance of natural resources that was the main origin of strife. The former thesis, ventured by authors such as Homer-Dixon (1999), gained relevance from concerns over environmental degradation as well as population growth. The latter thesis - one that focused entirely on 
high-value goods such as oil and minerals - highlighted the workings of 'honey pots' (de Soysa 2002) and 'resource curses' (cf. Watts 2004).

Connected to the notions of scarcity and abundance are the factors of greed and grievance, as highlighted by Murshed (Chapter 3 ). The greed argument is closely linked to the abundance-of-resources thesis: different parties may try to gain control over valuable resources for financial gain. The proceeds may be used to finance the conflict that they are involved in, and in this way the conflict may perpetuate itself. In the end, it may impossible to tell whether the conflict is about political power in order to obtain natural resources, or about natural resources in order to obtain political power.

In short, the grievance argument runs as follows: relative deprivation of countries, regions or groups causes grievance, which in turn fuels intra- or international conflict. Grievance is very likely in so-called "exclusive states" (Smidt et al, Chapter 5), in which certain groups are systematically excluded or marginalised, such as South Africa under the Apartheid regime or the situation in the West Bank and the Gaza strip. More generally, grievance is closely related to power imbalance. Not only does power imbalance often lead to relative deprivation of some countries, regions or groups, it may also be resented for its own sake and stand in the way of conflict resolution because the deprived parties may doubt the possibility of a fair outcome (cf. Gray 1989). In practice, greed and grievance may reinforce each other: conflicts that start with the greed of one group may result in relative deprivation of other group and in grievance, and grievance may develop into greed.

The next category of conflict origins, to which we have in fact already shifted, lies in the social realm. Frerks et al. (Chapter 2), for example, refer to the workings of 'identity politics' (cf. Watts 2004). These can have ramifications for our topic when particular groups claim territories and natural resources as their own, to the exclusion of others. However, 'identity' is not necessarily the cause, but can also be the result of political struggles. Ethnic and other differences between groups can be invoked to form and strengthen collective identities. This in turn may serve several political purposes: to claim natural resources for one's own group; to construct a common enemy and rally support for the ruling elite; to exclude contestants for power with a different 'ethnical background'; to marginalise more moderate contestants from one's own group; and to defend against other groups playing the ethnic card (Fearon and Laitin 2000; Caselli and Coleman 2013).

The final category of causes is institutional in nature. Arsel et al. (Chapter 7), focus on nationalisation processes in Bolivia and Ecuador, processes that are interpreted as integral parts of historical trajectories of conflict over extractive industries. The understanding of the dynamics at play requires transcending the issue of ownership to include an analysis of coinciding state transformations. It is argued that in the process of instigating nationalisation and acquiring some form of ownership of natural resources, the state is itself transformed by increasing its remit and powers. Rutten et al. (Chapter 4) further emphasise the importance of institutional and historical origins of conflict. The authors show how multi-layered competing claims can arise from the history of property rights associated with changing administrative boundaries.

Law, taken in a broad, sociological sense (Zaitch et al., Chapter 6), plays an important role in various contributions to the volume. Zaitch et al. explicitly refer to formal environmental law and its repeated transgression. Their perspective is one of green criminology. Other authors make use of a legal pluralism framework, which 
recognises the existence of various cognitive and normative orders in a social field (Benda-Beckmann 2002; Tamanaha et al. 2012). De Theije et al. (Chapter 8), for example, discuss the various patterns of law in three Latin American countries, and their roles in the creation and perpetuation of conflict. Bavinck et al. (Chapter 9) carries out a similar exercise, comparing the role of law in fishing conflicts in two parts of the world. The fact that multiple parties refer to different legal systems creates confusion, but also contributes to strife. As industrial fishers and governments do not recognise customary law and the rights it promotes, small-scale fishers in Sri Lanka and South Africa have no alternative than to protest. As De Theije et al. (Chapter 8) point out: legal pluralism is firmly embedded in power relations. This makes the question of which order prevails a very political one.

Having reviewed the history of the debate on conflict over natural resources, Frerks et al. (Chapter 2) plead strongly against mono-causal explanations, noting that, where tensions about access and use of natural resources exist, these generally prove to have multiple sources. Their reading of the contemporary literature is that: "At present, scholarship tends to promote a multi-causal, multi-level and multi-actor perspective in which the role of environmental factors is mediated through or combined with other factors, often of a socio-political nature" (Frerks et al., Chapter 2). The contributors to this volume would probably all agree with this nuanced and cautious perspective, which contrasts starkly with the polarising debate that took place on the topic in the not so distant past.

In this volume, the causes of and mechanisms toward cooperation receive less explicit attention than those of conflict. However, as the two concepts are to some extent mirror images of one another, much of what is said about one also applies to the other. Accordingly, the causes of cooperation can partly be assumed to be the opposite of the causes of conflict.

Embedded in the different literatures are hints that allude to the mechanisms for realising cooperation. Governance literature addresses the need to 'steer' society by means of collaboration between parties belonging to state, market and civil society (Kooiman 2003). Torfing et al. (2012: 54) point out that "governance arenas are ridden with political conflicts and power struggles," and that cooperation between parties is not necessarily forthcoming. Whether governance results in an appropriate and fair use of natural resources is another question altogether - there are enough examples of 'bad governance' in the world to demonstrate that this is not an obvious outcome. It is in this context that the concept of 'good enough governance' (Grindle 2004) has relevance; good enough, perhaps, to sense the possibility of unwanted conflict, and also to sow the seeds of cooperation. Yet it remains likely that even in this case governance will need to be based on principles and vision for conflict to be avoided (Kooiman and Jentoft 2009). Collaborative governance aims to engage people across divides for "a public purpose that could not otherwise be accomplished" (Emerson et al. 2012: 2).

In her classic work on inter-organisational cooperation, Gray (1989) developed a process model of cooperation, consisting of three phases: 1) problem setting, including the identification of key stakeholders; 2) direction setting, including reaching agreement; and 3) implementation. She emphasised, among others, the importance (and difficulty) of bringing the key stakeholders around the table, of identifying overlapping concerns when setting the agenda, of involving constituencies that have to approve or implement agreements, and of so-called 'reference organisations' that may 
oversee implementation. According to her, parties may be willing to cooperate if they a) consider the present situation to be unsatisfactory, and b) believe there is a chance of a better outcome that will actually be implemented and is also fair. Other authors on inter-organisational cooperation have identified a number of 'themes' to be addressed, such as organising for cooperation (networks, commissions, etc.), the issue of developing trust and goal setting (Huxham and Vangen 2005).

Still other literature that is highly relevant for understanding cooperation include the literature on negotiation and mediation, such as the classic Getting to Yes by Fisher and Ury (1981), which emphasises the importance of 'principled negotiation' and of exploring more than two options. Other classics include Robert Axelrod's book, The Evolution of Cooperation (Axelrod 1984) and Elinor Ostrom's work on collective action with regard to common pool resources (Ostrom 1990). Finally, many case studies and meta-analyses have been published in the past three decades on wholly or partly successful cases of cooperation, for instance in the field of transboundary water resources (Mostert 2003). Important lessons from these case studies include the importance of opportunities to interact, for instance in river basin commissions; the role of package deals and issue linkage; and the importance of developing good relations as a basis for mutually profitable exchanges.

\section{I.4 TAKING ACTION}

Although the projects that comprise the CoCooN programme all possess a strong action component, in this volume we have chosen to highlight their academic perspectives. Whereas many academics aim to further knowledge, policy is about the practical measures needed to address an issue directly.

There are two chapters in this volume, however, that do take a more explicit action perspective. The first is Chapter 10 (Timko, Chapter 10), which, as discussed in the previous section, focuses on the biofuel issue and its impact on livelihoods. The second action-oriented chapter by Kessler et al. (Chapter 11) hones in on the CoCooN programme itself. It describes how this programme, which is innovative in its explicit linking of research and policy goals, was designed and structured. This chapter connects with the discussion that Frerks et al. (Chapter 2) devote to the policy concerning conflict and cooperation over natural resources, both in the Netherlands and abroad, and the manner in which key agents have addressed the nexus between environmental issues and conflict.

Researchers deciding to engage with practice face a number of complications, similar to those of so-called action research (Masters 1995). First of all, there is the choice of what to work for and whom to work with (Mostert and Raadgever 2008). Although these choices follow partly from the topic of study and the possibility of identifying suitable action partners, there clearly is a normative element involved. In the CoCooN programme, more so than in conventional research, researchers collaborate with action partners on work that they consider important from a normative, societal viewpoint. Being interested in the situation of those that are excluded, and therefore marginalised and poor, they strive to contribute to a governance process that provides more equal benefits. As such, researchers become part of the governing process they are studying. 
The choice for specific goals and action partners may of course have consequences for the relations of researchers with other parties in the societal field. After all, their research is also a political activity that may be distrusted/opposed by other - more dominant - parties. One of the challenges posed by the CoCooN programme is how to manoeuvre in this potential minefield. Future publications from the programme will hopefully pay attention to how this question is being handled.

Finally, conflict resolution usually takes more time than is available during individual projects, and cannot necessarily be planned in advance. In the case of transboundary water resources, the time to resolve conflicts and develop real cooperation has been estimated to be between ten and a hundred years (Mostert 2003). Contrast this with the duration of a normal research project: four to five years. It may already take one year to make the necessary connections and gain enough trust. Moreover, unforeseen development can always occur, such as revolutions, natural disasters, changing policies and personnel changes. These make it difficult to develop a strict working plan in advance, and then stick to it throughout the project's implementation. Yet, this is what most funders require.

\section{I.5 WAYS FORWARD}

The picture of conflict and cooperation over natural resources presented in this book is necessarily complex and multi-dimensional. Conflicts prove to involve very different parties located in different parts of the world, at different geographical levels, and with or without a transboundary dimension. They can be open or hidden under the guise of cooperation, and based on greed, grievance or other circumstances, such as identity. Finally, conflicts are to be seen within their broader environmental, social and political contexts: whereas sometimes the environmental dimension predominates, in other cases it is the social or political realm that provides the main drivers. Cooperation has equally diverse forms. Significantly we noted that conflicting interests do not necessarily exclude cooperation.

Given the diversity of conflict and cooperation dynamics and their relation with natural resources, general causal theories are problematic. Rather than aiming for grand explanations, the researchers involved in the CoCooN programme strive to realise what Merton ([1949] 1967) has termed 'middle-range theory'. Their methods are comparative case study research and thick, data-rich analyses. Moving beyond the confines of analytical science into what Aristotle called phronesis, they also contribute to society's practical rationality "in elucidating where we are, where we want to go, and what is desirable according to diverse sets of values and interests" (Flyvbjerg 2001: 167).

Overall, given pending questions on the relationships between resource extraction, conflict and cooperation, in combination with the ever-increasing resource demands of the global economy, the issues dealt with in this book will likely remain prominent in academic and policy debates. Progress with regard to both knowledge and practice will depend on the willingness of academics, policy makers, practitioners and communities to engage with each other and make hard choices. The end results will be borne primarily by those who depend on natural resources for a living. Although books generally do not change the world, we hope that this volume will make a contribution 
to understanding the processes that lead to the marginalisation of poor, rural people, who are fighting for what they see as their rights over natural resources.

\section{REFERENCES}

Adger, W.N., I. Lorenzoni and K.L. O’Brien 2009. Adapting to climate change - thresholds, values, governance. Cambridge: Cambridge University Press.

Abu Sarah, A. 2011. What is normal about normalization?. Retrieved 8 October, 2012, from http://972mag.com/what-is-normal-about-normalization/31262/.

Axelrod, R. M. 1984. The evolution of cooperation. New York: Basic Books.

Benda-Beckmann, F. von 2002. 'Who's Afraid of Legal Pluralism?', Journal of Legal Pluralism 47: 37-82.

Caselli, F. and W. J. Coleman. 2013. On the Theory of Ethnic Conflict. Journal of the European Economic Association 11, no. s1: 161-192.

CIESIN (Center for International Earth Science Information Network) 2006. Where the Poor Are: An Atlas of Poverty. Palisades, NY: Columbia University. Available at: http://www.ciesin.columbia.edu/povmap/. (accessed November 24, 2013).

Emerson, K., T. Nabatchi, and S. Balogh 2012. An integrative framework for collaborative governance. Journal of Public Administration Research and Theory 22: 1-29.

Fearon, J. D. and D. D. Laitin. 2000. Violence and the social construction of ethnic identity. International Organization 54, no. 4: 845-877.

Fisher, R. and W. Ury. 1981. Getting to yes: negotiating agreement without giving in. Boston, Houghton Mifflin.

Flyvbjerg, B. 2001. Making Social Science Matter: Why Social Inquiry Fails and How it Can Succeed Again. Cambridge: Cambridge University Press.

Georgescu Roegen, N. 1975. Energy and Economic Myths. Southern Economic Journal 41, no. 3: 347-381.

Gray, B. 1989. Collaborating : finding common ground for multiparty problems. San Francisco: Jossey-Bass.

Grindle, M.S. 2004. Good Enough Governance: Poverty Reduction and Reform in Developing Countries. Governance 17 (4): 525-548.

Homer-Dixon, Th. 1999. Environment, Scarcity and Violence. Princeton: Princeton University Press.

Huxham, C. and S. Vangen. 2005. Managing to Collaborate: The Theory and Practice of Collaborative Advantage. London: Routledge.

Kooiman J. 2003. Governing as governance. London: Sage

Kooiman J. and Jentoft S. 2009. Meta governance, values, norms and principles, and the making of hard choices. Public Administration 87 (4): 818-836

Masters, J. 1995. The History of Action Research. In Action Research Electronic Reader, ed. I. Hughes. The University of Sydney, on-line http://www.behs.cchs.usyd.edu.au/arow/Reader/ rmasters.htm (accessed November 24, 2013).

Merton R.K. (1949) 1968. On theoretical sociology - five essays, old and new. New York: The Free Press.

Millennium Ecosystem Assessment 2005. Ecosystems and human well-being. Synthesis. Island Press, Washington, DC.

Mostert, E. 2003. Conflict and co-operation in international freshwater management; A global review. Journal of River Basin Management 1, no. 3: 1-12.

Mostert, E. and G. T. Raadgever. 2008. Seven rules for hydrologists and other researchers wanting to contribute to the water management practice. Hydrology and Earth System Sciences 12: 1087-1096. 
Ostrom, E. 1990. Governing the commons: the evolution of institutions for collective action. Cambridge: Cambridge University Press.

Peluso, N.L. and M. Watts (eds.). 2001. Violent environments. Ithaca, NY: Cornell University Press.

Scoones, I. 2009. Livelihoods perspectives and rural development. The Journal of Peasant Studies 36 (1): 171-196.

Sen, A. 2009. The idea of justice. Cambridge (MA): Harvard University Press.

Sikor, T. and C. Lund. 2009. Access and property: a question of power and authority. Development and Change 40, no. 1: 1-22.

Soysa de, I. 2002. Ecoviolence: Shrinking Pie, or Honey Pot?, Global Environmental Politics 2 (4): $1-34$

Tamanaha, B.Z., C. Sage and M. Woolcock 2012. Legal pluralism and development : scholars and practitioners in dialogue. Cambridge: Cambridge University Press.

Torfing, J., B.G. Peters, J. Pierre and E. Sørensen 2012. Interactive governance: advancing the paradigm. Oxford: Oxford University Press.

Watts, M. 2004. Resource curse? Governmentality, Oil and Power in the Niger Delta, Nigeria. Geopolitics 9, no. 1: 50-80.

Zeitoun, M. and N. Mirumachi. 2008. Transboundary water interaction I: reconsidering conflict and cooperation. International Environmental Agreements: Politics, Law and Economics 8, no. 4: 297-316.

Zeitoun, M. et al. 2010. Transboundary water interaction II: the influence of 'soft'power. International Environmental Agreements: Politics, Law and Economics: 1-20. 



\title{
Conflict and cooperation on natural resources: Justifying the CoCooN programme
}

\author{
Georg Frerks' ${ }^{\prime}$ Ton Dietz ${ }^{2}$ \& Pieter van der Zaag ${ }^{3}$
}

\begin{abstract}
This chapter provides an overview of the recent academic debates about the link between natural resources and conflict, and the policy initiatives in the field of resource governance that have formed the background of the collaborative knowledge, research and innovation programme on Conflict and Cooperation over Natural Resources in Developing Countries (CoCooN). It aims to highlight the contrasting viewpoints and debates on the nexus between conflict and resources, while simultaneously demonstrating that a level of convergence between those views has been developing over the last decade. Moreover, it demonstrates that several initiatives have been developed in the international and Dutch policy domains that attempt to contain or prevent resource-related conflicts. The chapter also outlines how the CoCooN programme has come into being and how it tries to respond to those debates and policy initiatives.
\end{abstract}

Keywords Natural resources, environmental conflict, environmental peace building, resource governance regimes, transparency, commodity tracking.

\section{I INTRODUCTION}

The last two decades have seen a rise in debates about the relationship between natural resources, conflict and peace-building in the fields of conflict studies, development studies, political science, political ecology/geography, environment and climate change. In the late 1990s, the nexus between natural resources and conflict centred on the issue of resource scarcity, and was three-cornered: a neo-Malthusian approach linking resource scarcity directly with social breakdown and conflict; a neoclassical economist approach focusing on institutions and innovation to conserve natural resources and thus preventing conflict; and a distributionist approach that highlights the

\footnotetext{
${ }^{1}$ Professor of Disaster Studies at Wageningen University and Conflict Prevention and Management at Utrecht University, Netherlands (Corresponding author: g.frerks@uu.nl).

${ }^{2}$ Director of the African Studies Center and Professor of African Development at Leiden University, Netherlands.

${ }^{3}$ Professor of Water Resource Management at UNESCO-IHE Institute for Water Education and Delft University of Technology, Netherlands.
} 
maldistribution of resources and wealth as key factors for conflict, and that perceives conflict and poverty as causes of resource depletion rather than consequences (HomerDixon 1995; 1999). Contrary to the focus on resource scarcity, the idea of resource abundance as a conflict factor emerged in the form of the so-called 'resource curse' - a concept that evolved from an economic interpretation connecting negative economic growth with natural resource wealth (e.g. Auty 1993; 1995) and extending it towards an idea that approaches resource abundance and dependency as central factors to the economics of conflict and civil war (e.g. Collier and Hoeffler 1998; Ross 1999; De Soysa 2000).

These binary positions, however, no longer dominate the debate. The present position is the recognition that natural resource degradation and scarcity may play a role in the rise of conflicts, but that conflicts can rarely be characterised as purely resource-driven. Where tensions about access and use of natural resources do exist, these depend on a variety of factors - the outcomes of which may sometimes cascade from tension into violent conflict, but certainly not always: they may also lead to cooperative solutions (Noorduyn 2005). More often than not, natural resource degradation is a result of conflict rather than a cause. The emergence of conflicts is now often seen as related to the management of natural resources or more widely to the nature of resource governance regimes (Adano et al. 2012). It is even argued that, when managed properly, resource issues may help to foster a culture of environmental cooperation and peace-building. In other words, proper resource governance could not only help resolve resource conflicts, but also prevent them and lead to peaceful mutual relations.

Instead of over-arching theories, there is presently a need for contextualised knowledge, and complexity needs to be explicitly acknowledged. It is for this reason that the Dutch Department of Development Cooperation (DGIS) and the Netherlands Organisation for Scientific Research (NWO) initiated a collaborative knowledge, research and innovation programme on Conflict and Cooperation over Natural Resources in Developing Countries (CoCooN) that is both focused on science and impact.

This chapter is structured as follows. After the introduction we attempt to review and summarise the debates in academia. Then we provide the policy perspective by referring to major initiatives and actions of a variety of supranational organisations, governments, the private sector, and non-governmental organisations. We then describe the CoCooN programme that attempts to fuse science and policy into one research agenda.

\subsection{CONFLICT AND COOPERATION ON NATURAL RESOURCES: THE ACADEMIC DEBATES}

In academia and policy circles there have been vivid and sometimes fierce debates on the nexus of environment and conflict. These discussions have taken different points of departure and have also revolved around diverging issues (see Hough 2008). This is in part explained by the different underlying (conflict) theories and associated paradigms, and the centrality of different key concepts. For some analysts, the degradation of the environment was a key explanatory factor of conflict at macro or micro-levels. Others took a different perspective, focusing instead on resource scarcity or distribution as 
the key issue, often concentrating on one particular resource or mineral. A third group elaborated the problem by adopting a broader livelihood approach, while a fourth group introduced the so-called economies-of-violence - the relation of natural resource extraction (Watts 2004a; 2004b) and 'greed' oriented approaches. In this framework the idea of resource abundance as a conflict factor (Billon 2001) also emerged: the so-called 'resource curse' (Collier 2000). More recently, debates have focused on the possible role of climate and climate change in promoting conflict in the future. Further, there has been a whole range of publications and viewpoints where environment is not seen so much as a conflict factor, but rather as a shared interest between conflict protagonists and, hence, as a window for peace building. This view builds on the idea of environmental security as part of a broader notion of human security, as promoted in the framework of the United Nations (UNDP 1994) and more recently scrutinised by Sheehan (2006) in his review of scholarly positions on international security. Finally, there are observers who feel that the 'securitisation' of the environment is a deficient approach, as it runs counter to the need for a broader, global environmental approach when dealing with these problems, something that a realist and nationalist approach is unable to deliver.

To understand these different debates properly, it is not only necessary to review their arguments and empirical bases, but also to position them within the wider discourse on development, security and conflict (Frerks 2007). It is, of course, hardly possible to aptly summarise the rich, diverse and sometimes intense debate on the nexus of environment, peace and conflict in a few lines. The summary overview below is hence unavoidably incomplete, selective and subjective to a certain degree (for more details on the debate see Klem (2003), who gives a good overview of the different 'schools' and trends in the 1990s, Gleditsch $(1998 ; 2001)$ and Sheehan (2006: 99114) for a critical analysis, and Schubert et al. (2008) for an up-to-date overview of the state of security and environment research and of the known conflict impacts of environmental change). A brief historical sketch of the major trends in contemporary discourse and an outline of some emerging issues will be given below.

\subsection{From old to new wars}

In conflict studies at large we have seen a shift from what has been called classical or 'modern' conflict to contemporary conflict, or as Mary Kaldor coins it, a shift from 'old' to 'new wars' (Kaldor 1999). Though the latter distinction is not absolute and in fact ideal-typical in nature, there are certainly salient differences in both the discourse and reality of old wars in comparison to new wars (see Richards 2005 for a critical review of the explanations of 'new wars'). Key differences include the focus on state versus human security respectively (see Commission on Human Security 2003; Frerks and Klein Goldewijk 2007a and 2007b), and the attention paid to military-strategic versus broader political, socio-economic and environmental factors (see Renner 2005; Worldwatch Institute 2005). This also implies a revision of the earlier realist and statecentred understanding of conflict and security, leading to the involvement of a whole set of non-state actors that deal with the lack of security, namely NGOs at intermediate levels and community-based organisations (CBOs) at the grassroots level (for literature on non-state governance and insecurity, see for example Menkhaus 2006, Lund 2006, Raeymaeckers 2012). 


\subsubsection{Greed versus grievance}

Reframing conflict as such led to an emphasis on non-traditional (i.e. non-military) conflict factors, including poverty, resource scarcity, identity, religion and the role of the environment. How those 'new wars' were funded and managed to perpetuate was also questioned, in particular by looking into resource exploitation and control. This brought into focus the role of non-state actors and the functioning of economies of violence, where wars were fought for the enrichment of state and non-state elites. In his early study of the 'benefits of war', David Keen (1998) argued that wars were not 'irrational', but instead pursued in a calculated attempt to derive economic benefits from them. Wars were not to be seen as 'politics by other means', as once observed by Clausewitz, but as 'economics by other means'. In the emerging greed-versus-grievance debate, analysts disagreed on the relative importance of politico-ideological factors (grievance) in comparison to economic factors (greed). Closely tied to the greed argument is Paul Collier (2000), the former Director of the Development Research Group at the World Bank. Collier and his team contended that, apart from income and growth levels, conflicts were related to proxies for greed (economies based on primary commodities and large numbers of poorly educated young men) rather than proxies for grievance (inequality, lack of political rights etc.). He submitted that rebel groups only adopted grievance discourses in an attempt to raise their legitimacy, but that grievances per se were not driving the conflict. According to Collier (2000), the possibilities for predation and for 'doing well out of war' were the real drivers of conflict. Political and ethnographic work showed that many wars in the so-called (neo-) patrimonial states in Africa and Asia were fought by elites in order to enrich themselves and their immediate entourage (Allen 1999; Chabal and Daloz 1999). However, it has also been suggested that greed often motivated elites rather than followers, or may only have become dominant in a later stage of the war when resources became necessary for the continuation of the war and replaced original ideological motives. The latter has often been argued in the case of the Colombian guerrilla movement FARC.

\subsubsection{Economies of violence}

Whatever the reason for starting a rebellion, Bannon and Collier maintain that rebel movements need to raise income to fund their wars. After all, without it they would 'wither away': "Where rural areas produce primary commodities with high economic rents, generally for export, it is a relatively simple matter for rebel groups to run an extortion racket, levying protection charges on producers or carrying out some of the trade themselves" (2003: 4). Recent fieldwork in the Ituri District in the DRC showed that both remnant rebel movements as well as the Congolese army resorted to such practices on a wide scale (Frerks and Douma 2007). Comparative case studies have also highlighted the role of economies of violence in particular war-torn countries (Douma 2005; Cilliers and Dietrich 2000). In those countries, it is 'resource abundance' rather than scarcity that creates the conflict. In effect, this notion conveys that concentrations of easily loot-able resources tend to attract violence rather than resources that are scarce. Examples mentioned include the resource wealth of countries like DRC, Sierra Leone, Liberia and Angola, though it remains a fact that these locally and abundantly available resources are obviously scarce at a global scale. 
Due to the linkages of these economies of violence with the larger world markets, the role of international trade and business came under closer scrutiny for being complicit in some of the wars in the 1990s and 2000s (Brown et al. 2007). In connection with this, some experts have called for the promotion of markets for conflict-free goods, the promotion of conflict-sensitive business as part of a larger emphasis on social corporate responsibility, and careful scrutiny of the revenues (and origin) derived from natural resources. Some major policy initiatives in this domain will be mentioned below. Another strand of critical analysts has suggested that the western world has been complicit in creating or permitting the existence of chaotic 'borderlands', so that conditions legitimised interventions - in the form of both armed invasions or peace-building - aimed at creating or installing a neo-liberal world order (Duffield 2005). Globalisation is additionally critically examined in this body of literature.

In all these attempts to rethink warfare in the post-Cold War era, environmental issues took on a new relevance. Apart from playing their usual role in the classical, but waning debates on sustainable development, they now acquired a new significance as factors causing or explaining contemporary conflict. Some analysts even suggested that this was nothing more than a cynical attempt by environmentalists to grab the government's attention and spending related to security (see Sheehan 2006: 99). Whatever the case, a plethora of studies, documents, seminars and policy statements emerged that promoted the idea of environmental conflict and even put it centre stage (Homer-Dixon 1999, Klare 2001). Among them were the more alarmist publications and scenarios that prophesied full-blown oil, water and resource wars. Though these early studies were instrumental in putting the idea of environmental conflict on the international academic and policy agenda, they tended to overstate the issue. Several leading scholars have questioned the definitional clarity, theoretical foundation, (causal) analysis and empirical basis of these earlier studies (Gleditsch 1998; 2001). The work by Collier and his colleagues at the World Bank was, for example, heavily criticised on substantive as well as methodological grounds (see Klem 2003 for details).

\subsubsection{The present position: an emerging consensus}

Insights are currently evolving into a more nuanced and qualified direction. At present, scholarship tends to promote a multi-causal, multi-level and multi-actor perspective in which the role of environmental factors is mediated through or combined with other factors, often of a socio-political nature (Gleditsch 2001). Mono-causal approaches highlighting the environment as the reason for war in the 21 st century have given way to a more modest approach in which environmental factors are certainly not discarded as a conflict factor, but positioned into a broader and more complex framework (see Allen 1999; Goodhand and Hulme 1999).

The present position is characterised by the recognition that the environment and associated factors like environmental degradation, resource scarcity and more recently climate change, do or may play a role in the rise and continuation of conflict, but are seldom the only or most important factor (see e.g. Trombetta 2008; Adano et al. 2012). Environmental issues must become politicised before they can lead to violent 
mobilisation. As observed by Karen Ballentine of the EACW project: "The correlation between natural resource dependency and conflict risk is not direct: variations in the state's governance are critical intervening factors" (2004: 4). Here, we see the interplay of political and socio-economic factors, often mobilised by conflict entrepreneurs through identity-politics that serve to arouse feelings of mutual distrust and hate. Identity politics works by emphasising the differences between different identity groups, such as race, ethnicity, religion, language or other characteristics, whether they are real or imagined. A straightforward land conflict, for example, can become much more difficult and protracted when an identity or ethnic factor is implicated. Watts (2004b:4) describes such identity-politics as 'governable spaces', where natural resources "generate differing sorts of governable spaces in which identity, territory and rule are in play."

This qualified position amounts to a debunking of simple (neo-)malthusian approaches that emphasise mono-causal or reductionist environmentalist explanations, where scarcity directly leads to conflict. As properly observed by Paul Richards (2005: 6-8), there is no "Malthus with guns." Following Gleditsch (2001: 64), environmental degradation may more appropriately be "seen as an intervening variable between poverty and poor governance on the one hand and conflict on the other. In this sense, environmental degradation may be seen more as a symptom that something has gone wrong than a cause of the world's ills."

We may conclude at this stage that the alarmist predictions of resource wars that received a level of prominence in the 1990s were not proven or substantiated. Scholarship at present stresses the complex and nuanced interplay between environmental and other factors. Linkages between environment and conflict have been found to be indirect at best. Analysis has moved from absolute to relative scarcity and to a focus on distributional issues among different identity groups. At subnational or local levels, smaller conflicts may indeed occur due to resource scarcity or mal-distribution. While there are occasionally instances of violence and incidental casualties, these fights are often not systematically organised and rarely endure. As such, they would not normally be classified as violent conflict or low-intensity warfare. Yet, there is a possibility that these local 'green-wars' escalate into more prominent national violence or even spill over to neighbouring countries. They must therefore be positioned and monitored in terms of declining rural livelihoods and related patterns of resource plunder, predation, overexploitation and depletion. At present it seems that rural livelihoods are allowed to deteriorate further in many countries, thereby increasing the chances that these types of conflict will emerge. The role of government (development) policy or mismanagement in forging or exacerbating socio-economic differentiation among different identity groups warrants further study. It appears that such processes are in fact often based on ill-informed or misdirected government processes, involving patron-client relations and corruption. We also see that many conflict contexts are characterised by so-called state failure or weak statehood - e.g. the 'predatory state' - and therefore lack the institutional mechanisms, will or capacity to prevent conflict from emerging or deal with conflict once it escalates towards violence. As mentioned, such state-centred perspectives have likewise come under scrutiny by research that focuses on informal institutions, non-state governance frameworks and traditional authorities that affect mechanisms of resource distribution. 


\subsubsection{Environmental peace building}

The whole idea of immanent resource conflict has glossed over the societal capacity to reach solutions. Wolf et al. (2005), for example, have convincingly shown that there have been very few 'water wars', while an impressive database of treaties and agreements demonstrates a tendency towards cooperation and what has been called 'institutional resilience', the capacity of institutions to cope with tensions about water and water scarcity. Similarly, Ohlsson (1999) has argued that resource scarcity is offset by adaptive capacity.

In response to the often-stressed conflictive aspect of the environment, it also has been presented as a conflict resolution and peace building opportunity, especially with regard to so-called renewable natural resources (such as water, fishing resources, forests, etc.). After listing a number of changes in the nature of current water disputes, Wolf et al. (2005: 94-95) argue that:

On the other hand, water is a productive pathway for confidence building, cooperation and arguably conflict prevention, even in particularly contentious basins. In some cases, water offers one of the few paths for dialogue to navigate an otherwise heated bilateral conflict. In politically unsettled regions, water is often essential to regional development negotiations that serve as de facto conflict prevention strategies. Environmental cooperation - especially cooperation in water resources management - has been identified as a potential catalyst for peace making.

Conca et al. (2005: 149) elaborate on this notion of environmental cooperation. They assert that: "As a peace building tool, the environment offers some useful, perhaps even unique qualities that lend themselves to building peace and transforming conflict." In particular, they pinpoint the fact that "environmental challenges ignore political boundaries, require a long-term perspective, encourage local and non-governmental participation, and extend community building beyond polarizing economic linkages." Ecological and other types of interdependency strengthen this potential for collaboration.

Carius (2007: 61) distinguishes between three partly overlapping categories of ecological peace initiatives: activities to prevent conflicts directly related to the environment; attempts to initiate and sustain a dialogue on trans-boundary environmental cooperation between parties to a conflict; and initiatives that seek a lasting peace by promoting conditions for sustainable development. The first category is usually dealt with by reducing the pressure on the resources and institutional mechanisms, the second by starting dialogues and establishing cooperation on shared environmental challenges, and the third one by reaching long-term sustainable solutions and management regimes (Carius 2007: 61-63). Carius elaborates on the complexities of such initiatives and the need to embed them in larger economic, political and institutional frameworks. He maintains that we lack sufficient knowledge and appropriate conditions to discuss their impact, and recommends a systematic and comparative analysis of previous case studies in order to engage in a constructive dialogue with policymakers to make environmental peacemaking more effective (2007: 72). Examples of environmental cooperation include trans-boundary reserves or trans-frontier parks and shared river basin initiatives. Van de Giessen (2005) describes the experiences in 
the tri-national Virunga Volcanoes region, home to the last remaining 380 mountain gorillas; while Büscher has done the same for the Maloti-Drakensberg Transfrontier area in Southern Africa (Büscher 2009). Apart from international or trans-boundary work, environmental peace building also includes cross-ethnic or cross-identity-group initiatives at the sub-national level. Frerks et al. (2006), for example, discuss how ethnic identity groups in the conflict-ridden context of Sri Lanka collaborate in a Dutch funded peace and development programme that was organised around shared interests, both environmental and cultural. Gaasbeek (2010) examines the collaborative inter-ethnic interaction of Tamil, Muslim and Sinhalese communities in the midst of war in the Sri Lankan Allai extension scheme, where the interest in joint water management and the shared feeling of all being farmers were able to resist divisive ethnic sentiments stirred up by outside forces for a long time.

\subsubsection{Livelihoods}

In this broader framework of analysis, Leiff Ohlsson's work on livelihood conflicts is especially relevant. His basic premise is that a common denominator of many conflicts, if not most conflicts in Africa, South Asia and Latin America, is poverty resulting from loss of livelihood that is in turn caused or exacerbated by environmental degradation. While poverty and environmental factors per se only have weak links with the occurrence of conflict, (agricultural or pastoral) livelihoods constitute a missing link in the explanations. Ohlsson (2000: 4) argues:

Great and growing scarcity of healthy, productive eco-systems in the world today seems to co-exist with an equally great and unused asset made up of all those women and men who lost their livelihood due to environmental destruction or unsustainable agriculture. A combination of these two aspects offers the potential for conflict prevention, poverty elimination and environmental reconstruction.

This may require refocusing on issues such as resource governance and management, and shifting from so-called failing states to the required earth system governance, as proposed for example by Biermann (2007). This connection between long-term changes in livelihoods and the institutional roles of conflict and cooperation in enhancing or destroying livelihoods deserves a relatively extensive historical analysis approach, as stated in the foundation literature of political ecology (e.g. Blaikie and Brookfield 1987). It requires an emphasis on the dynamics in the 'entitlements to natural resources' (Dietz 1996), an integration of aspects of power, ideology and violence that affect access to and control over 'livelihood assets' (Jackson 2006), as well as empirical attempts to connect histories of relative abundance and scarcity with histories of conflict (as in Witsenburg and Adano 2007; Adano and Witsenburg 2008). Highly efficient resource use systems have often developed under conditions of resource scarcity. In more popular terms, tension and conflict may also be seen as a source of innovation and creativity to adapt land-use and governance systems. In a broader setting it may link up with Boserup's theory in opposition to Malthusian thinking that looks at population pressure and scarcity as a requirement for technological innovation (e.g. Burger and Zaal 2009). 


\subsubsection{From scarcity to variability}

Research on ecological change and dynamics in more densely populated zones and semi-arid areas in East and West Africa has seriously challenged the idea of increasing scarcity (Tiffen et al. 1994; Scoones 1995; Mazzucato and Niemeijer 2000). African environments display much more variability than commonly assumed. Likewise, processes of environmental change are much more complex and varied than usually portrayed (Fairhead and Leach 1996). This variability has resulted in complex systems of property and access rights to natural resources. Even in situations of ecological pressure, scarcity is not an unequivocal phenomenon, but varies considerably in time and space and among households, genders and individuals. Catching this variability and its differential effects on people's vulnerability in analysis and policy practice is of the essence. Additionally, various layers of customary, religious and state law interact in natural resource management, leading to considerable ambiguity on the ground and, hence, space for compromise and negotiation. Social and political relations between the parties involved largely determine the outcomes of such localised conflicts. Based on status, specific groups of people may be denied access to resources or can be increasingly marginalised (De Bruijn and Van Dijk 2003). Answers to these questions must be sought in local ethnic and political relations, institutional strength, governance structures, and patterns and processes of group identification (Schlee 2004).

The Cochabamba and El Alto 'water riots' that took place in Bolivia in 2000 and 2005 are cases in point. Neither riot was about the scarcity of water, but instead about the privatisation of customary water rights (Assies 2003; Boesen and Ravnborg 2004). This gave rise to another kind of water wars thesis, predicting violent protest against injustice due to unreflective privatisation and globalisation (Shiva 2002). The same debate is now emerging with regard to the potentially violent outcomes of the implementation of climate change mitigation and adaptation policies, where it is not climate change or the effects of climate variability that cause major social unrest and violence, but instead climate change policies that interfere with existing institutions or undermine existing social arrangements.

\subsubsection{Interdependence}

The idea that water interdependence may lead to cooperation and benefit sharing rather than competition and conflict has currently taken hold of debates surrounding water rights. UNESCO's ongoing From Potential Conflict to Cooperation Potential Project ${ }^{4}$ reflects this focus on co-operation, while Allan (2001) has argued that international food trade eases the stress on water-scarce regions such as the Middle East, as cheap food imports ensure that water stressed countries save water that would otherwise be depleted in the production of food (virtual water). Still, while the pessimists have thus far been proved wrong, the London Water Research Group that has emerged around Allan warns that there is scant reason for optimism about international cooperation. The expectation of 'water peace' is undermined by many examples of non-implementation of international water treaties, hegemonic power play and unresolved structural conflict (Zeitoun and Warner 2006). It appears that conflict

\footnotetext{
${ }^{4}$ See: www.unesco.org/water/wwap/pccp/
} 
and cooperation go in tandem and should be analysed simultaneously (Zeitoun and Mirumachi 2008; see also Van der Zaag and Carmo Vaz 2003).

A focus on interstate water relations alone is insufficient, because the multi-level nature of water security must be taken into consideration. Sub-state actors see their insecurity increased as a result of violent acts, interstate collusion in hydraulic development (Furlong 2006) and war. It is therefore important to focus one's analysis on how violence (war), development (peace), water and 'virtual water' flows between states impact on the security of affected groups, and on relations within and between communities and regions at the sub-national level.

\subsection{CONFLICT AND COOPERATION ON NATURAL RESOURCES: THE POLICY PERSPECTIVE}

\subsection{International concerns}

Though the environment has been an important thematic domain within global development cooperation since the 1980s and conflict too entered the arena in the latter part of the 1990s, the nexus between environment and conflict was relatively underexposed in international policy debates. Despite vehement discussions of the topic in the late 1990s in academia (mainly with regard to the causation of conflict), this debate did not reverberate in policy circles to such a degree that it impacted policy design and implementation. The debates at that point in time were still insufficiently couched in operational terms, and it was therefore difficult for policy makers to conceive initiatives that could be translated into 'bankable projects'.

There was probably also a need to first collect more evidence-based material and carry out case studies to inform policy. One can, however, observe a recent change and the nexus environment and conflict has clearly entered into the policy debates in a number of prominent institutions, while programmes are being defined or implemented that deal with the issue in practice. For a historical overview of (inter)national initiatives on environment, conflict, peace and security, see Conca et al. (2005: 146149). Additionally, there are an increasing number of case and thematic studies focused on pertinent aspects of the problem. A report by DFID (2007), for example, described in detail the trade flows of natural resources and other commodities out of the Democratic Republic of the Congo (DRC) through the Great Lakes region and East Africa. The goal of this project was to enhance the sustainable and equitable use of the DRC's natural resources in the interest of poverty reduction in the country and stability in the region by way of building a robust evidence base for policy. The purpose was to provide a regional dimension to the analysis and understanding of natural resource exploitation in the DRC. Apart from the exploitation and trans-boundary trade in natural resources, the report stresses the importance of local livelihoods and governance. This study is exemplary of many others that underlie a wide range of policy initiatives undertaken over the last couple of years.

Below we offer a selection of some major policy initiatives in this regard. These are presented with the purpose of illustrating the recent trend by focusing on a limited number of institutions of different types rather than to suggest any representative or exhaustive overview. 


\section{The United Nations and the United Nations Security Council}

The United Nations (UN) and the UN Security Council (SC) have been aware of the link between natural resources and conflict for many years. In response, the SC has passed sanctions, set up committees and groups of experts, and authorised several peacekeeping operations to assist in monitoring and implementing sanction regimes. In 1993 the SC already passed an oil embargo against UNITA in Angola. In 1997 and 2000 it imposed oil and diamond sanctions on Sierra Leone, and in 1998 it instituted diamond embargoes against UNITA. Liberia faced diamond and timber embargoes in 2001 and 2003 respectively, and Côte d'Ivoire faced similar diamond sanctions in 2005, when the so-called Pretoria Agreement showed the first signs of disintegration. In the UNMIL, UNOCI and MONUC peace missions, special cells or units have been established to both study and, where appropriate, deal with the control and management of natural resources or with the embargoes when these were still in place. At the 2005 World Summit the SC adopted resolution 1625 that reaffirmed "its determination to take action against illegal exploitation and trafficking of natural resources and high-value commodities in areas where it contributes to the outbreak, escalation or continuation of armed conflict."

In an open debate in 2007 (Belgian Presidency 2007), the Security Council reiterated the importance of cooperation among source, transit and destination countries in preventing and combating trafficking, illicit trade and illegal exploitation of natural resources, and referred to the important contribution of commodity monitoring and certification schemes such as the Kimberley Process. It also recognised the role of voluntary initiatives aimed at improving revenue transparency, such as the Extractive Industries Transparency Initiative (see below). The Council also noted the important contribution of voluntary principles and standards in encouraging the private sector in general and multinational enterprises in particular to adopt a responsible business conduct.

More generally, the Council emphasised that the lawful, transparent and sustainable management of natural resources is a critical factor in maintaining stability and in preventing a relapse into conflict (Security Council SC/9060). With regard to all those topics, important developments have occurred over the last years. Yet, the question in all of these debates revolves around the degree to which the SC should deal with those issues itself, rely on the initiative of other UN mechanisms (such as the General Assembly or the new Peace-building Commission), or encourage initiatives outside the UN framework and regional approaches. In this regard, a regional perspective seems to be logical, as the issue of natural resources has an important cross-border dimension.

\section{World Bank}

The World Bank's Development Research Group has provided an important impetus to the formulation of insights and policies on the nexus of natural resources and conflict, by carrying out a research project on the economics of civil war, crime and violence. In 2011, the World Bank even devoted its annual World Development Report to the topic of 'Conflict, Security and Development' (World Bank 2011). In an attempt to forge practical approaches and policies for the international community, the World Bank's Conflict Prevention and Reconstruction Unit and the Development Research Group further set up the Governance of Natural Resources Project in 2002. The edited volume 
by Bannon and Collier (2003) outlines the insights and policy recommendations that have emerged from this project. They recommend general measures promoting global development, believing development in general to reduce conflict. With regard to the governance of natural resources specifically, they discuss a whole series of measures: increased transparency of natural resource revenues; certification of origin; checking of finance of illicit commodities; scrutiny of illicit payments; and attracting reputable companies to risky environments.

\section{Extractive Industries Transparency Initiative (EITI)}

The lack of transparency and accountability of the payments that companies make to governments and the revenues that governments receive from those companies compounds effective ameliorative international action. The Extractive Industries Transparency Initiative (EITI) launched by British Prime Minister Tony Blair on the World Summit for Sustainable Development in September 2002, seeks to ensure that transparency and accountability. EITI is a voluntary initiative supported by a coalition of companies, governments, investors and civil society organisations that follow the so-called EITI Principles adopted in 2003. In 2005 a set of criteria for the implementation of the EITI was formulated and actions to be taken by governments and industries were compiled in a source book. Through the EITI, citizens can hold governments and industries accountable for the origin and use of the revenues resulting from extractive industries (Extractive Industries Transparency Initiative 2005).

\section{International and governmental transparency initiatives}

EITI is closely linked to a number of similar initiatives. The G8 countries, for example, issued a Declaration on Fighting Corruption and Improving Transparency at Evian in 2003. The IMF has promoted fiscal transparency in member countries via the voluntary Code of Good Practices on Fiscal Transparency and the associated manual. Implementation of the code is monitored through the production of Reports on the Observance of Standards and Codes (ROSCs). Both the IMF and the World Bank promote more effective resource revenue management through policy advice, policy-based and project lending, and technical assistance. The OECD has developed Best Practices for Budget Transparency and a Due Diligence Guidence for Responsible Supply Chains of Minerals from Conflict-Affected and High-Risk Areas. A sectoral example is The Forest Law Enforcement and Governance (FLEG) Ministerial Process focusing on East Asia, which aims "to increase the amount of forest-related rent that accrues to the government and to prevent the illegal appropriation of such rent, including via illegal logging” (Swanson et al. 2003: 62). In 2005, the European Union adopted a Voluntary Partnership Agreement mechanism under FLEG, with (in 2012) implementation agreements in Cameroon, Ghana (Beeko and Arts 2010) and the Republic of Congo, and new initiatives in other African and Asian countries. ${ }^{5}$ Section 1502 of the Dodd-Frank Act - passed by the US Congress in July 2010 - foresees a disclosure requirement that calls on companies to determine whether their products contain conflict minerals, which some fear will put a de facto embargo on minerals from the DRC, forcing many artisanal miners to seek alternative livelihoods.

\footnotetext{
${ }^{5}$ See: http://ec.europa.eu/environment/forests/flegt.htm
} 
Many of the initiatives mentioned here are relatively new and implementation is still in its infancy, having yet to be properly reviewed. Swanson et al. (2003) argue that reporting by host governments in the developing world is rudimentary and often consciously evaded, as they themselves are often involved in commodity rackets and hence have no incentive whatsoever to divulge reality. Countries have also created 'offbudget funds', 'trust funds' or 'stabilisation', 'savings' or other 'special funds' outside the normal budget systems and oversight procedures. Ascher (1999: 259) observes that the "apparently weak enforcement 'capacity' is as much a choice as a 'given,' and lack of enforcement capacity is often part of the strategy of resource manoeuvres." In some countries, Indonesia and Chile being notorious examples, the military was highly involved in natural resource exploitation through off-budget accounts that were secret. In such situations, transparency initiatives are highly problematic and often actively undermined.

\section{Non-governmental transparency initiatives}

There are many NGO-led campaigns that aim at promoting transparency. One wellknown example is the Publish What You Pay campaign spearheaded by Global Witness and George Soros. These types of initiatives usually focus on the issue of corporate social responsibility and the respective companies' reputations. The European Coalition on Oil in Sudan (ECOS) - coordinated by IKV Pax Christi Netherlands - focuses on oil companies active in that country, arguing that the income from oil is fuelling the war (Frerks 2008). Similarly, the Caspian Revenue Watch was started by the Open Society Institute (part of the Soros Foundation) and focuses on the investment of revenues from natural resources. These three examples are only an illustration of the existing wide variety of non-governmental actions.

\section{Transparency initiatives at company level}

In this section we give only a few salient examples to illustrate the initatives focused on the corporate world and often initatied by them as well. The OECD Guidelines for Multinational Enterprises agreed to by 33 OECD governments and several non-OECD governments are non-binding recommendations for companies based or operating in their jurisdictions. The guidelines form part of the OECD Declaration on International Investment and Multinational Enterprises. The Global Reporting Initiative provides guidelines for companies (and other entities) to report their economic, environmental and social performance.

Swanson et al. (2003: 49, 72) report that the mining groups under the Mining, Minerals, and Sustainable Development (MMSD) Project have worked with Transparency International to increase the transparency of agreements between mining companies and governments. Nine of the world's largest mining companies initiated the project through the World Business Council for Sustainable Development. The MMSD Project focuses on research, a process of stakeholder engagement and a program of information exchange.

A final example is the UN Global Compact. This is a voluntary code of conduct first proposed by UN Secretary General Kofi Annan in a speech to the Davos Economic Forum in 1999. The nine principles of the Global Compact cover the areas of human rights, labour, and the environment and are based on international agreements, notably 
the United Nations Universal Declaration of Human Rights, the International Labour Organisation Fundamental Principles on Rights at Work, and the (UN) Rio Principles on Environment and Development. The main requirement for participation is that companies provide a brief report once a year on concrete actions they have taken as well as any lessons they have learned from doing so.

\section{Commodity tracking systems}

For a whole range of commodities, specific control or tracking systems have been developed. These have been designed for a variety of goals, including the protection of endangered species, environmental concerns, ethical concerns (child labour) or security-related issues. Crossin et al. (2003: 97-159) provide an extensive discussion and overview of commodity tracking systems (CTRs). These authors distinguish between five essential elements of CTRs: common definitions and reporting requirements, effective reporting structures and information exchange, commodity labelling and audited chain-of-custody arrangements, compliance and enforcement measures, and capacity building. In a table, they describe eleven major tracking regimes and their governing institutions. Some more well-known examples of CTRs include the Kimberley certification process scheme for diamonds, the Convention on International Trade in Endangered Species of Flora and Fauna (CITES), the Cartagena Protocol on Biosafety, The Basel and Rotterdam Conventions of hazardous waste and chemicals, and the Forest Stewardship Council for timber. It goes beyond the scope of this chapter to review all details of such systems, but there is generally some optimism with regard to their potential impact. However, the weaknesses and lack of enforcement mentioned above by Swanson and Ascher with regard to transparency initiatives generally apply to CTRs as well.

\subsubsection{Dutch concerns}

The Dutch government was among the first to put the issue of intrastate conflict on the policy agenda. In the early 1990s, the Dutch development cooperation minister Jan Pronk linked the domains of development and conflict, and of development cooperation and defence (Ministerie van Buitenlandse Zaken 1993). This was further reflected in Dutch policy practice, which endeavoured to resolve or mitigate the effects of conflict through diplomatic, humanitarian and development initiatives in a variety of conflict and post-conflict situations. These developments were supported by a conscientious policy research effort, involving different agencies, as well as a particularly important role for non-governmental agencies (e.g., the co-financing agencies, IKV Pax Christi). Many development cooperation initiatives took place in conflict-prone areas. An integrated approach was promoted that combined instruments of diplomacy, defence and development (the so-called 3-D approach or whole-of-government approach) to deal with a series of interrelated problems in weak states and conflict areas. In Dutch global policies, conflict prevention and conflict management, as well as stabilisation and reconstruction were mentioned as important policy goals. The importance of good governance and the proper management of natural resources were emphasised. Resource scarcity and mal-distribution compounded by patterns of patronage were deemed to be among the causes of Africa's multiple conflicts. 
In 'Een zaak van iedereen' (Everyone's Concern) (Ministerie van Buitenlandse Zaken 2007), the policy paper on development cooperation written by then minister Bert Koenders, much attention was paid to the subject of conflicts. The paper clearly demonstrated the global and political dimensions of natural resources and conflict. It highlighted the close relations between energy resources such as oil and gas, and conflicts that hamper human development in many countries worldwide. Involved are factors of unequal access to energy resources, interests of industrial countries to secure energy sources, and powerful political elites in countries where governance is poor. For other countries, reference was made to other valuable resources, such as timber (e.g. DRC), diamonds (Liberia) or drugs (Colombia, Afghanistan), as a major source of conflict hindering development and poverty reduction. The policy paper introduced the subject of so-called fragile states, which were characterised by a high level of instability and intra-state conflict. Such states were considered to be a global risk, e.g. because of large numbers of refugees and the threat of terrorism. Lastly, the subject of climate change was highlighted, leading to shortages in water resources and food, health problems, migration and conflict over natural resources that the poor suffer from in the first place.

The (then) Department of Environment and Water (DMW) of the Dutch Ministry of Foreign Affairs also wrote a policy paper about Environment, Water and Poverty Reduction (Ministerie van Buitenlandse Zaken 2006). The objective of this strategy was "to promote innovation in policies and programmes in the field of environment and water that will contribute to poverty reduction and to the achievement of the Millennium Development Goals; and to strengthen institutional capacity to this end in developing countries." The document pinpointed the organisation of knowledge management and the allocation of resources to key research(able) problems as central issues to be addressed. Core themes were: (a) environment and land rights, land management and agriculture in landscape systems under pressure; (b) environment (e.g. cross-border parks) and water (e.g. international rivers and lakes) in relation to conflict generation and conflict resolution; (c) environment, conflict and the role of illegal trade.

\subsubsection{Other approaches}

In addition to to the international and Dutch concerns that mainly referred to 'high politics', there are many other initiatives that deal with environmental conflict. Examples include track-2 and track-3 diplomacy to resolve existing or escalating conflicts. Even more importantly, however, are initiatives taken to set up institutional arrangements to deal with conflict in, among others, shared river-basins, water management schemes, conservation and nature parks, ecological zones, and areas of resource exploitation. These take a variety of shapes from the international to the very local level and include international river commissions, multi-stakeholder platforms, irrigation, farmers' and users' committees, and trans-boundary commissions, to name but a few. It would require a separate study to observe in detail the ways in which such institional arrangements work and another to examine their effectiveness, but three aspects are of importance here. In the first place, they focus on one particular aspect within a larger conflict context and in this way make the approach more feasible; secondly, they enable face-to-face contacts on the basis of a joint interest, possibly leading to a 
humanising and de-escalating position; thirdly, they almost always involve local stakeholders, but also have the possibility of engaging higher level actors. Such specific institutions may have their roots in existing (traditional) forms of rule and governance and are therefore less susceptible to institutional deficiencies in fragile state settings. We would encourage a detailed study of the strengths and weaknesses of these types of institutions, as they may form a crucial missing link in the governance regimes that most of the authors reviewed above have deemed so crucial.

\subsection{JOINING SCIENCE AND POLICY:THE CoCooN INITIATIVE}

The developments above form the backdrop against which the research programme on Conflict and Cooperation over Natural Resources (CoCooN) was developed in 2008.

\subsection{CoCooN's understanding of conflict}

When the first discussions within the CoCooN team started, it was immediately accepted that conflict should not only be seen as something negative or destructive. Here the CoCooN team, comprised of researchers and policy makers with a long personal history in 'development and environment' connected seamlessly with researchers in the Conflict research programme that had been initiated by the Netherlands Organisation for Scientific Research NWO two years earlier (NWO 2006). The following were major considerations in formulating the CoCooN programme. Conflict has detrimental, negative and destructive powers, but it can also be a key driver of change. Conflict brings creative potential that helps families, organisations and states to (re)define themselves, to innovate and to create. There is a need to not only look at conflict as an agent of negative impacts, but also as an agent of positive change. It was thus recognised that tension and conflict may also be seen as a source of innovation and creativity in the adaptation of land-use and governance systems. This was also recognised in the preceding academic discussion of the peace-building potential of environmental tensions and conflicts, the need to cooperate in trans-boundary settings, and the emphasis of institutional resilience of water conflicts, as highlighted by Wolf et al. (2005).

Of further importance is the need to understand protracted conflict situations in some so-called 'failed' or 'fragile' states in Africa, Asia and Latin America. The continuation of conflict may be in the interest of some involved parties, and a longitudinal research orientation to conflict will yield a better understanding of these processes. For instance, in the case of economies of war with heavy investments in arms and drugs trade, or vested interests in oil, diamond and timber, multiple parties seem to benefit from prolonged rather than resolved conflict. The question is then, under what conditions would the parties involved be more interested in collaboration and peace processes than conflict. This issue was also mentioned in section 2 , where the greed versus grievance debate was noted, as well as in section 3 where a variety of initiatives were discussed that could help contain the greed of power-holders and companies by a range of coercive and non-coercive measures.

Without a doubt, the scale of the problem of potentially violent conflicts has increased, and so too have the interests at stake. Recently, debates have focused on the possible role of climate change in causing conflict in the future (e.g. Welzer 2008). The 
growing demand for biofuels has given rise to increasing competition with local food security and competing claims over land and water resources, giving rise to many new research initiatives. Global markets and trade patterns create tensions when markets rapidly expand or shrink. With respect to marine resources, there are growing pressures on declining fish stocks and as a result tensions between artisanal and industrial fishing fleets have intensified. A range of factors including environmental governance issues, processes of empowerment and social action determine whether tensions evolve into conflict or may induce cooperation. Understanding these dynamics is critical for the livelihoods of millions of people who directly depend on natural resources for their day-to-day living. It is here that the complexity of environmental conflict needs to be taken into account. The political factors and wider livelihood dynamics that together with environmental factors co-produce tension and conflict need to be unravelled and understood if ameliorative action is to be undertaken. The centrality of well-functioning natural resource governance regimes can hardly be overstated in this regard.

Considering the above, CoCooN has identified four key features that need to be taken into account when conducting research on conflict and natural resources: multicausality, the multifaceted functions of conflict, the dynamic and longitudinal nature of conflict, and cross-level influences. In our prior academic and policy analyses, the relevance of those issues became crystal clear. Though at first sight this may add to the overall complexity of both analysis and policy practice, it does not have to lead to paralysis; issues can be dealt with through a targeted and sequentialist approach that does not address everything at once, but instead tackles the issues bit by bit.

\subsubsection{Creating usable knowledge}

Another major consideration was that knowledge and innovation were seen as essential to the development process. The focus was no longer on discovering new technological and institutional principles as much as it was on how to make better use of the existing stock of knowledge and ensure this was translated into effective governance mechanisms. Knowledge sharing is an important source of creating innovation, but inequalities in the capacities for accessing and using knowledge continue to pose a constraint to development in many countries. Moreover, the study of conflict and cooperation over natural resources spans several levels of analysis and bridges many disciplines. At the same time, the current speed of change in response to the interplay of various global factors requires new forms of linking existing bodies of knowledge with innovative research and experimentation.

\subsubsection{Objectives}

In view of those challenges, the CoCooN programme first aims to conduct high quality research and enhance innovation in the field of natural resources and conflict. Secondly, it hopes to contribute to positive change by providing contributions to evidence-based policy development and practice in this area. Thirdly, it intends to make the knowledge gained available, and this volume is one of the means in achieving this, in addition to a range of other publications, seminars and conferences. 
The CoCooN programme has put local demand articulation and ownership at the forefront of the research in order to effectively provide knowledge for development and bring about positive change in the interface between natural resources and conflict. CoCooN's focus on a positive contribution to development implies that its knowledge and research activities are strongly embedded in the wider development context and are part of an innovation system. It requires active interaction with key stakeholders in demand articulation, design and execution of concrete research projects. This has enhanced the societal relevance and incorporation of results in policy and practice. As discussed in section 3, the active involvement of NGOs and beneficiaries in the diverse tracking systems, monitoring and advocacy initiatives can assist in fostering a more effective approach in reality, where the goals, approaches, outcomes and impacts are shared among the stakeholders involved and may also serve as examples for others, thereby replicating itself in other areas and domains.

\section{REFERENCES}

Adano, W. R. and K.Witsenburg. 2008. Pastoral Sedentarisation, natural resource management, and livelihood diversification in Marsabit District, Northern Kenya. Two volumes. Lampeter: Edwin Mellen Press.

Adano, W. R., T. Dietz, K. Witsenburg and F. Zaal. 2012. Climate Change, Violent Conflict and Local Institutions in Kenya's drylands. Journal of Peace Research Special Issue (ed. N. P. Gleditsch) 49, no. 1 (January): 65-80.

Allan, J. A. 2001. The Middle East Water Question, Hydropolitics and the Global Economy. London: I.B. Tauris.

Allen, C. 1999. Warfare, Endemic Violence and State Collapse in Africa. Review of African Political Economy 81: 376-384.

Ascher, W. 1999. Why Governments Waste Natural Resources: Policy Failures in Developing Countries. Baltimore: Johns Hopkins University Press.

Assies, W. 2003. David versus Goliath in Cochabamba. Water rights, neoliberalism and the revival of social protest in Bolivia. Latin American Perspectives 30, no. 3: 14-36.

Auty, R.M. 1993. Sustaining Development in Mineral Economies: The Resource Curse Thesis. London: Routledge.

Auty, R.M. 1995. Industrial Policy, Sectoral Maturation, and Postwar Economic Growth in Brazil: The Resource Curse Thesis. Economic Geography 71, no. 3: 257-272.

Ballentine, K. 2004. Program on Economic Agendas in Civil War: Principal Research Findings and Policy Recommendations. New York: International Peace Academy.

Bannon, I. and P. Collier (eds.). 2003. Natural Resources and Violent Conflict, Options and Actions. Washington DC: World Bank.

Beeko, C. and B. Arts. 2010. The EU-Ghana VPA: a Comprehensive Policy Analysis of its Design. International Forestry Review 12, no. 3: 221-230.

Belgium Presidency of the Security Council. 2007. Maintenance of International Peace and Security: Natural resources and conflict. Concept paper for the Security Council Open Debate.

Biermann, F. 2007. Knowledge for the Sustainability Transition: Earth System Governance as a Crosscutting Theme of Global Change Research. In Human Security and International Insecurity, ed. G. Frerks and B. Klein Goldewijk, 197-217. Wageningen: Wageningen Academic Publishers.

Blaikie P. and H. Brookfield (eds). 1987. Land degradation and society. London: Methuen. 
Boesen, J. and H. M. Ravnborg (eds.). 2004. From Water 'Wars' to Water 'Riots'? - Lessons from Transboundary Water Management; Proceedings of the International Conference, December 2003, DIIS, Copenhagen. Copenhagen: Danish Institute for International Studies.

Brown, O., M. Halle, S. Peña Moreno and S. Winkler (eds.). 2007. Trade, Aid and Security, An Agenda for Peace and Development. London: Earthscan.

Bruijn M.E. de and H. Van Dijk. 2003. Risk Position and Local Politics in a Sahelian Society. The Fulbe of the Hayre in Central Mali. In African Environment and Development: Rhetoric, Programs, Realities, ed. B. Moseley and B. Ikubolajeh, 140-158. London: Ashgate Publishing.

Burger, K. and F. Zaal. 2009. Sustainable Land Management in the Tropics. Explaining the Miracle. Farnham: Ashgate

Büscher, B. 2009. Struggles over consensus, anti-politics and marketing. Neoliberalism and transfrontier conservation and development in Southern Africa. Phd diss., Amsterdam VU University.

Carius, A. 2007. Environmental Peacebuilding: Conditions for Success, Special Report. Environmental Change and Security Program Report, Issue 12, 2006-2007, 59-75. Washington DC: ECSP.

Chabal P. and J. P. Daloz. 1999. Africa Works: Disorder as Political Instrument. Oxford: James Currey.

Cilliers, J. and C. Dietrich (eds.). 2000. Angola's War Economy. The Role of Oil and Diamonds. Pretoria: Institute for Security Studies.

Collier P. and A. Hoeffler. 1998. On Economic Causes of Civil War. Oxford: Oxford Economic Papers 50.

Collier, P. 2000. Doing Well out of War: An Economic Perspective. In Greed and Grievance: Economic Agendas in Civil Wars, ed. M. Berdal and D. M. Malone, 91-112. Boulder: Lynne Rienner Publishers.

Commission on Human Security. 2003. Human Security Now. New York: Commission on Human Security.

Conca, K., A. Carius and G.D. Dabelko. 2005. Building Peace Through Environmental Cooperation. in The State of the World 2005: Redefining Global Security, Worldwatch Institute, 144-155. New York/London: W.W. Norton \& Company.

Crossin, C., G. Hayman and S. Taylor. 2003. Where Did It Come From? Commodity Tracking Systems. In Natural Resources and Violent Conflict, Options and Actions, ed. I. Bannon and P. Collier, 97-157. Washington DC: World Bank.

Department for International Development. 2007. Trading for Peace - Discussion Paper. London: DFID.

Dietz, T. 1996. Entitlements to natural resources. Contours of political environmental geography. Utrecht: International Books.

Douma, P.S. 2005. The Political Economy of Internal Conflict. A comparative Analysis of Angola, Colombia, Sierra Leone and Sri Lanka. The Hague: The Netherlands Institute of International Relations 'Clingendael'.

Duffield, M. 2005. Human Security: Development, Containment and Re-territorialization. The Globalization of Security. ISP/NSC Briefing Paper, ESRC, 2: 3-5.

EITI (Extractive Industries Transparency Initiative). 2005. Extractive Industries Transparency Initiative Sourcebook. London: EITI Secretariat DFID.

Fairhead, J. and M. Leach. 1996. Misreading the African Landscape: Society and Ecology in a Forest Savanna Land. Cambridge: Cambridge University Press.

Frerks, G. 2007. Conflict, Development and Discourse. In Human Security and International Insecurity, ed. G. Frerks and B. Klein Goldewijk, 45-63. Wageningen: Wageningen Academic Publishers.

Frerks, G. 2008. The European Coalition on Oil in Sudan, 2001-2007, IKV Pax Christi Best Practice Study no. 3, July 2008. Wageningen: Wageningen University, IKV Pax Christi, ECOS, $1-55$. 
Frerks, G. and P. Douma. 2007. Local Peace Initiatives in Ituri, DRC, 2003-2007, IKV Pax Christi Best Practice Study no. 2. Wageningen: Wageningen University, Disaster Studies.

Frerks, G. and B. Klein Goldewijk (eds.). 2007a. Human Security and International Insecurity. Wageningen: Wageningen Academic Publishers.

Frerks, G. and B. Klein Goldewijk. 2007b. Human Security: Mapping the Challenges. In Human Security and International Insecurity, ed. G. Frerks \& B. Klein Goldewijk, 21-44. Wageningen: Wageningen Academic Publishers.

Frerks, G, Klem, B and H. de Mel. 2006. Evaluation of Peace and Development Programme, Report on the Second Phase of the Programme. Utrecht/The Hague: Centre for Conflict Studies, Utrecht University/Clingendael Institute.

Furlong, K. 2006. Hidden theories, troubled waters: International relations, the 'territorial trap', and the Southern African Development Community's trans-boundary waters. Political Geography. xx: 1-21.

Gaasbeek, T. 2010. Bridging Troubled Waters? Everyday inter-ethnic interaction in a context of violent conflict in Kottiyar Pattu, Trincomalee, Sri Lanka. PhD. diss., Wageningen University.

Giessen, E. van de. 2005. Natural Resources: source of violence, source of peace, a study on the role of natural resources in violence and peace in the African Great Lakes region with special attention to the tri-national Virunga Volcanoes region. MSc. diss., Utrecht University.

Gleditsch, N.P. 1998. Armed Conflict and the Environment: A Critique of the Literature. Journal of Peace Research 35, no. 3: 381-400.

Gleditsch, N.P. 2001. Environmental Change, Security and Conflict. In Turbulent Peace, the Challenge of Managing International Conflict, ed. C.A. Crocker et al., 53-68. Washington: United States Institute of Peace.

Goodhand, J. and D. Hulme. 1999. From Wars to Complex Political Emergencies: Understanding Conflict and Peacebuilding in the New World Disorder. Third World Quarterly 20, no. 1: $13-26$.

Homer-Dixon, Th. 1995. The Ingenuity Gap: Can Poor Countries Adapt to Resource Scarcity? Population and Development Review 21, no. 3: 587-612.

Homer-Dixon, Th. 1999. Environment, Scarcity and Violence. Princeton: Princeton University Press.

Hough, P. 2008. Understanding Global Security. London: Routledge.

Jackson, P. 2006. Protecting Livelihoods in Violent Economies. In Profiting from Peace Managing the Resource Dimension of Civil War, ed. Ballentine and Nitzschke, 153-184. London: Lynne Rienner Publishers.

Kaldor, M. 1999. New and Old Wars: Organized Violence in a Global Era. Stanford Ca.: Stanford University Press.

Keen, D. 1998. The Economic Functions of Violence in Civil Wars, Adelphi Paper 320. London: Institute for Strategic Studies.

Klare, M.T. 2001. The new geography of conflict. Foreign Affairs 80, no. 3: $49 \mathrm{ff}$.

Klem, B. 2003. Dealing with Scarcity and Violent Conflict. Working Paper Series, Working Paper no. 24. The Hague: Netherlands Institute of International Relations 'Clingendael' and National Institute of Public health and Environment (RIVM).

Le Billon, P. 2001. The Political Ecology of War: Natural Resources and Armed Conflict. Political Geography 20, no. 5: 561-584.

Lund, C. 2006. Twilight Institutions: Public Authority and Local Politics in Africa. Development and Change 37, no. 4: 685-705.

Mazzucato, V. and D. Niemeijer. 2000. The Cultural Economy of Soil and Water Conservation: Market Principles and Social Networks in Eastern Burkina Faso. Development and Change 31: 831-855.

Menkhaus, K. 2006. Governance without Government in Somalia: Spoilers, State Building, and the Politics of Coping. International Security 31, no. 3: 74-106. 
Ministry of Foreign Affairs. 1993. Een Wereld in Geschil. De grenzen van de Ontwikkelingsamenwerking Verkend. The Hague: Ministry of Foreign Affairs.

Ministry of Foreign Affairs. 2006. Knowledge, Innovation and Research Strategy (KOS), Environment, Water and Poverty Reduction. The Hague: Ministry of Foreign Affairs.

Ministry of Foreign Affairs. 2007. Een Zaak van Iedereen. Investeren in ontwikkeling in een veranderende wereld. The Hague: Ministry of Foreign Affairs.

Noorduyn, R. 2005. The assertion of rights to agro-pastoral land in North Cameroon: a cascade to violence? Leiden: African Studies Centre Research Report 76.

Netherlands Organisation for Scientific Research (NWO). 2006. 'Conflict and Security' Theme: Conflict: Functions, Dynamics, and Cross-Level Influences. Proposal for NWO Strategic Theme 2007-2011. The Hague: NWO.

Ohlsson, L. 1999. Environment, Scarcity, and Conflict: A Study of Malthusian Concerns. Göteborg: Göteborg University.

Ohlsson, L. 2000. Livelihood Conflicts: Linking Poverty and Environment as Causes of Conflict. Stockholm: SIDA.

Raeymaeckers, T. 2012. Reshaping the State in its Margins: The State, the Market and the Subaltern on a Central African Frontier. Critique of Anthropology 32, no. 3: 334-350.

Renner, M. 2005. Security Redefined. In The State of the World 2005: Redefining Global Security, Worldwatch Institute, 3-19. London: W.W. Norton \& Company.

Richards, P. 2005. New War, An Ethnographic Approach. In No Peace No War, An Anthropology of Contemporary Armed Conflict, ed. P. Richards, 1-21. Athens/Oxford: Ohio University Press/James Currey.

Ross, M.L. 1999. The political economy of the resource curse. World Politics 51: 297-322.

Schlee, G. 2004. Taking Sides and Constructing Identities: Reflections on Conflict Theory. Journal of the Royal Anthropological Institute (N.S.) 10: 135-156.

Schubert, R. et al. 2008. Climate Change as a Security Risk. London: Earthscan for German Advisory Council on Global Change (WBGU).

Scoones, I. (ed.). 1995. Living with Uncertainty. New Directions in Pastoral Development on Africa. London: Intermediate Technology Publications.

Security Council. 2007. Presidential Statement S/PRST/2007/22. New York: Department of Public Information SC/9060.

Sheehan, M. 2006. International Security, An Analytical Survey. New Dehli: Viva Books Private Limited.

Shiva, V. 2002. Water Wars. London: Pluto Press.

Soysa, I. De. 2000. The resource curse: are civil wars driven by rapacity or paucity? In Greed and Grievance: Economic Agendas in Civil Wars, ed. M. Berdal and D.M. Malone. Boulder: Lynne Rienner.

Swanson, P., M. Oldgard and L. Lunde. 2003. Who Gets the Money? Reporting Resource Revenues. In Natural Resources and Violent Conflict, Options and Actions, ed. I. Bannon and P. Collier, 43-96. Washington DC: World Bank.

Tiffen M., M. Mortimore and F. Gichuki. 1994. More People, Less Erosion. Environmental Recovery in Kenya. Chicester: John Wiley.

Trombetta, M.J. 2008. Environmental Security and Climate Change: Analysing the Discourse. Cambridge Review of International Affairs 21, no. 4 (December): 585-602.

United Nations Development Programme (UNDP). 1994. Human Development Report 1994. New York/Oxford: Oxford University Press.

Watts, M. 2004a. Resource curse? Governmentality, Oil and Power in the Niger Delta, Nigeria. Geopolitics 9, no. 1: 50-80.

Watts, M. 2004b. The Sinister Political Life of Community: Economies of Violence and Governable Spaces in the Niger Delta, Nigeria. Working Paper 3. Berkeley, CA: Institute of International Studies, University of California. 
Welzer, H. 2008. Klimakriege. Wofür im 21.Jahrhundert getötet wird. Frankfurt am Main: Fischer Verlag.

Witsenburg, K. and Adano W. R. 2007. The Use and Management of Water Sources in Kenya's Drylands. Is there a Link between Scarcity and Violent Conflicts? In Conflicts Over Land and Water in Africa, ed. B. Derman, R. Odgaard and E. Sjaastad, 215-238. Oxford: James Currey. Wolf, A. T., A. Kramer, A. Carius and G. D. Dabelko. 2005. Managing Water Conflict and Cooperation. In The State of the World 2005: Redefining Global Security, Worldwatch Institute, 80-95. London: W.W. Norton \& Company.

World Bank. 2011. Conflict, Security and Development. World Development Report 2011. Washington: World Bank.

Worldwatch Institute. 2005. The State of the World 2005: Redefining Global Security. London: W.W. Norton \& Company.

Van der Zaag, P. and A. Carmo Vaz. 2003. Sharing the Incomati waters; cooperation and competition in the balance. Water Policy 5: 349-368.

Zeitoun, M. and J. Warner. 2006. Hydro-Hegemony: A Framework for Analysis of Transboundary Water Conflicts. Water Policy 8: 435-460.

Zeitoun, M. and N. Mirumachi. 2008. Transboundary water interaction I: reconsidering conflict and cooperation. International Environmental Agreements 8: 297-316. 


\title{
New directions in conflict research \\ from an economics perspective
}

\author{
Syed Mansoob Murshed'
}

\begin{abstract}
This chapter begins by looking at the causes of internal conflict in developing countries, reviewing the rational choice debate between greed and grievance as a cause of conflict. It argues that these explanations may be complementary, and the breakdown of the institutions behind conflict resolution, or the social contract, may explain why large scale internal conflict breaks out. It looks at the relationship between globalisation and conflict, bearing in mind that civil war is only one form of violent organised internal conflict, and the fact that the relationship between economic progress, and the risk of conflict may be non-linear, with both growth and the absence of growth producing conflict risk. It then closely examines the relationship between natural resource endowment and conflict risk, arguing that economic dependence on certain types of resources and its associated weak institutions are more likely to produce conflict. The growing prevalence of sectarian and civilisational conflict is also outlined, along with the argument for a need for studying conflict at a more local, sub-national level of analysis.
\end{abstract}

Keywords Internal conflict, civil war, social contract, globalisation and conflict, natural resources and conflict.

\section{I INTRODUCTION}

Even an idealist philosopher like Immanuel Kant (1795) considered war to be the natural state of man. In that respect, he shared the perspective of the English philosopher Thomas Hobbes (1651). According to Hobbes, the state of nature was characterised by anarchy akin to perpetual war. Life was "solitary, poor, nasty, brutish and short" (Hobbes 1651: 84). Consequently, self-interest dictated that individuals should relinquish their personal freedom to an absolute ruler who could ensure personal security and rule based interactions in society. Kant was concerned more with the prevention of war between nations. That would require the simultaneous adoption of a republican constitution by all nations, which inter alia would check the war-like tendencies of both monarchs and the citizenry; the cosmopolitanism that would emerge among the

\footnotetext{
${ }^{1}$ Professor of Economics of Sustainable Development at the International Institute of Social Studies (ISS), Erasmus University, Rotterdam Netherlands, and Coventry University, UK (Corresponding author: murshed@iss.nl).
} 
comity of nations would preclude war, implying a confederation amongst such nation states (foedus pacificum). Kant's notion of cosmopolitanism is also applicable within nation states. Both thinkers were concerned with mechanisms that would engender peace. In other words, peace has to be achieved through deliberate design; this is what Galtung (1964) described as the negative peace (the absence of war).

Within nation states, civil war is only one manifestation of large-scale violent conflict. It is important to emphasise that civil 'war' involves the direct participation of the state and military style confrontations. Since the end of the cold war, conflict research has been dominated by the study of civil war in developing countries and in the former Soviet bloc. One of the factors that contribute to the gestation of many of these civil wars is natural resources, an issue that becomes central to the causation of civil wars in a variety of guises. These include the violent contestation of valuable natural resource rents, normally restricted to minerals, fuels and narcotic substances. The loss of local control over resource rents and resource use (to central government and the forces of globalisation) is often an important source of the grievances that breed conflict. Also, population growth and climate change can induce neo-Malthusian factors leading to the scarcity of land, forests and water resources for agriculture, forestry or pastoral activities may ignite internal conflict (Homer-Dixon 1999).

The discourse on the nature of civil war has gradually evolved into a discussion of development or state failure, depending upon the disciplinary or political stance of the interlocutors. Coinciding with this, there has been a growing proclivity on the part of Western governments and international organisations to become directly involved in conflict affected developing countries after the demise of the cold war, and the associated undermining of Westphalian state sovereignty.

The number of armed conflicts peaked in 1991, when 52 wars occurred in 38 countries. By 2007, however, this number had declined to 34 wars in 25 countries (Gleditsch 2008). Likewise, associated conflict fatalities are also declining. There is one caveat, the number of Muslim countries experiencing civil war as a proportion of all countries in civil war is rising. Civil (and inter-state) war incidence is on the wane, but other forms of violent conflict may be rising, and these do not always involve the state as a direct participant.

For example, violence associated with democratic transitions in many parts of the developing world is still rife. It has been found that the risk of conflict is higher during transitions from an autocratic to a democratic system and vice versa than in longstanding and established autocracies or democracies (Hegre et al. 2001). Although there has been a marked shift towards democracy in most developing countries since the end of the cold war, and most have adopted the multi-party electoral system to form governments, they still lack adequate constraints on the executive and their electoral systems are fraught with imperfections. We might, therefore, better describe these states as anocracies as opposed to democracies. An anocracy has characteristics of both democracy and autocracy; most developing countries fall into this category, raising conflict risk, as will be seen from the discussion below.

Secondly, the losers of increased globalisation, which widens the gulf between the 'haves and have nots', sometimes transform their protests into violent insurgencies. Rapid globalisation, especially in the form of increased international trade and inward foreign investment has increased income differences between skilled and unskilled workers all over the world (Mamoon and Murshed 2008), and income inequality 
generally (Milanovic 2011). In many developing societies, rural hinterlands have been particularly disadvantaged; where it is combined with ethnic differences with the majority of the state's population, this relative backwardness can constitute a recipe for violent (Maoist style) insurgencies. Recent increases in food and fuel prices, coupled with real resources devoted to debt servicing present new vulnerabilities. The important point is that such relative deprivation can take place even when the nation's aggregate economic performance is impressive and growth is both positive and buoyant. Thirdly, there are ethnic or communal conflicts where groups compete over dwindling resources, such as those utilised in agriculture (Homer-Dixon 1999) or other contestable endowments like land. Many of these ethnic conflicts do not include the state as a direct participant.

Contemporary violent internal conflict does not always take the form of civil war; it can be associated with both developmental success and failure, the more acute form of the latter is often referred to as state failure. Mass protest and communal strife are becoming increasingly important forms of internal conflicts in developing countries. Thus, even in successful developing countries and emerging market economies such as India, globalisation and growth can lead to new forms of conflict. Furthermore, democracy does not serve as a panacea for conflict prevention.

This chapter summarises the state of the art on the origins of violent internal conflict in developing countries, highlighting the connection with natural resources. The rest of this work is organised as follows. Section 2 contains an outline of new forms of vulnerability and an integrated theory of conflict and development. Section 3 presents a sketch of the relationships between natural resources and conflict or cooperation. The salience of the local nature of new types of conflict is described in section 4, while section 5 outlines issues in sectarian (communal) conflict based on ethnic difference. Finally, section 6 is by way of conclusion, pointing to certain lacunae in conflict research.

\subsection{CONFLICT AND UNDERDEVELOPMENT/DEVELOPMENT}

Nowadays, organised large-scale conflict in developing countries is almost universally regarded as a source of human development failure, the perpetuation of poverty and human insecurity, all of which enhance the risk of failed states. Equally, endemic poverty and state failure enhance the risk of civil war and conflict. Therefore, the developmental goal of poverty reduction requires conflict prevention. Conflict (even in distant lands) further undermines international security, and thus conflict prevention, abatement and resolution are paramount if the costs of dealing with state failure are to be avoided. Following on, both developmental and security considerations necessitate conflict prevention via human development and poverty reduction. In practice, however, it is difficult to separate the development and security agendas. In 1941, during the Second World War, President Franklin Delano Roosevelt proclaimed four fundamental freedoms. Among these were the freedom from want and the freedom from fear. The former may be regarded as akin to human development. When we combine it with the freedom from fear it helps shape our notion of human security. Once again, these two freedoms are inextricably intertwined, because without security, ensuring livelihoods is meaningless. Likewise, the converse is equally true. In policy 
terms, for example, the reduction of absolute poverty, connected with the millennium development goals (MDGs), yields a double dividend by simultaneously addressing security and developmental concerns.

In the past three decades, and particularly since the end of the cold war, there appears to be a greater incidence of developmental failure and, in the extreme form, state failure, which sometimes leads to violent conflict. Related to these phenomena are the functions of the state. Is the state benevolent or predatory? A great deal has been written on this, but what is salient is that we are increasingly regarding the innate nature of the state in developing countries as factional or predatory. We seem to have left behind the idea that the state should be a functionary agent of society. Even within the predatory category, there are shades of grey associated with good, moderate or bad governance. In many ways, these distinctions among states mirror Olson's (1996) stationary and roving bandit dichotomy. A stationary bandit (state) nurtures the tax base (society) so that more can be extracted in the future, while a roving bandit is only bent on what can be extorted here and now.

\subsection{Causes of conflict risk}

One robust result in the empirical cross-country civil war literature is that per-capita income and conflict risk are significantly and negatively correlated. Although this finding may disguise the mechanisms that truly underlie the statistical association, conflict risk is heavily associated with developmental and state failure. My contention is that both development failure and rapid development (or growth) enhance conflict risk. Additionally, factors external to the nation state can also enhance conflict risk.

Within the rational choice literature on conflict, two broad factors, greed and grievance, have been closely linked to the recent (post-cold war) onset of civil war (see Chapters 3 and 5 in Murshed 2010 for a lengthier elaboration of the arguments that follow in this sub-section). If we were to summarise the greed argument in Collier and Hoeffler (2004), conflict reflects elite competition over valuable natural resource rents, often concealed under the fig leaf of collective grievance. Economic, political and social inequalities play an insignificant role in this process, as these types of grievances are omnipresent in any society. Rather, it is the opportunity afforded by natural resource rents as a ready source of finance for war that is crucial to these forms of violent disputation. There is also a poverty trap in this connection: poverty makes soldiering a less unattractive livelihood strategy, lowering the opportunity cost of war in poor nations. In turn, conflict serves to perpetuate poverty, because of war's destructiveness and a vicious cycle of poverty-conflict-poverty ensues (see, for example, Paul Collier and associates for the World Bank 2003). Fearon and Laitin (2003) assert that civil war risk is mainly associated with diminished state capacity to either deter violent challenges to the state or assuage underlying grievances through transfers and government expenditure. This finding, taken together with Paul Collier's work, has a simple intuitive appeal: civil wars occur in poverty stricken, failed states characterised by venal, corrupt and inept regimes, where the dynamics of war are sustained by a motivation akin to banditry. It also provides the intellectual basis for direct, colonial style intervention in collapsed or failing states.

Against this is a long-standing view that relative deprivation (Gurr 1970) and the grievance that it produces fuels internal violence, although the original argument of 
Ted Gurr pertained more to individual motivation rather than group dynamics. Identity is also crucial to intra-state conflict. Group dynamics require the resolution of the collective action problem, as discussed in Olson (1965). In order to mobilise large groups to undertake collective action and fight other groups, intra-group mistrust, monitoring difficulties and the free-rider problems have to be overcome. Ethnic identities, whether based on race, language, religion, tribal affiliation or regional differences, may serve as a more effective amalgam for the purposes of group formation compared to other forms of difference based on individual inequality such as socioeconomic class. No conflict can proceed without the presence of palpably perceived group differences or grievances, which may have historical dimensions. Frances Stewart (2000) coined the phrase horizontal inequality, the inequality between groups, rather than individual inequality within otherwise homogenous populations (vertical inequality). Crucial here are the more enduring (or hard to change) dimensions of inequality (Tilly 1998), and inequality of opportunity, compared to relatively more transient causes of inequality (like current income), such as the manner in which certain groups are discriminated against, simply because of their ethnic characteristics, as opposed to other personal attributes.

\subsubsection{Social contract}

Ultimately, the greed and grievance motivations for conflict may actually be inseparable. Even if one theory is better at motivating the start of conflict, the other phenomenon is sure to follow. Thus, it is not uncommon for a conflict linked to palpable grievances, for example, to mutate into a situation where the rebels become greedy, and both greed and grievance can be seen to co-exist. It appears that the greed explanation for conflict duration and secessionist wars performs well, in terms of statistical significance, in cross-country studies, but has to make way for grievance-based arguments in country-case studies, even in quantitative analyses. Grievances and horizontal inequalities may, after all, be better at explaining why conflicts begin, but not necessarily why they persist because conflicts require finance, and without internal mechanisms of war finance conflicts may be quickly ended by external intervention (unless the external intervention backs one side in a civil war). Although the presence of either greed or grievance is necessary for the outbreak of violent conflict, they are not sufficient. This requires institutional breakdown for peaceful conflict resolution, which may be described as the failure of the social contract (Murshed 2010). The remainder of this sub-section summarises the arguments therein.

The social contract refers to the mechanisms within society that resolve conflict without outright violence. It contains a moral, economic and political component both at national and local levels. It also implies a functional view of the state: governments exist to serve a purpose, and rule is by consent. Contemporary civil wars are more often related to the breakdown of explicit or implicit mechanisms to share power and resources, rather than the complete absence of an agreement to govern these. This is true even in the most extreme cases of so called state failure, such as in Somalia. Cold war rivalries and the interventions of external powers in the domestic affairs of other countries may also undermine an existing social contract. Among the various factors, two domestic reasons leading to the decline of the social contract deserve special mention. 
The first point refers to the resource sharing agreements. In a well ordered society, some understanding usually exists about sharing revenues and/or expenditure between those in power and others not in power; the breakdown of these arrangements or the undermining of the credibility of existing commitments to resource sharing can produce greed and/or grievance. There are many examples of conflicts that emerge out of fiscal disputes, something that can be exacerbated in the context of economic decline. Disputes over the apportionment of revenues from natural resources are especially common and, as in Nigeria and Indonesia, these often take on ethnic and regional dimensions. Additionally, the social contract is less likely to hold when ruling regimes prefer repression to making transfers that assuage rebellion.

Secondly, there is the political system. Hegre et al. (2001) point out that the risk of conflict is lower in both well-established democracies and autocracies. This suggests that conflict risk is at its greatest during transitions to and away from democracy, when state capacity is weak, and also in fledgling and imperfect democracies (anocracies). State capacity (its ability to both police citizens and provide public goods) is greater in established autocratic or democratic societies, rather than in those somewhere in the middle. Thus, there may be an inverted u-shaped relation between democracy and internal conflict: increased democracy is first associated with rising violence, after a critical point in democratic achievement, conflict and violence diminish. In other words, democratic transitions may induce a greater risk of violence, unless managed well via systems of power sharing and constraints on the executive.

The activities of the state are important in maintaining the cohesiveness of society, which relates to a functioning social contract. In addition to a Weberian monopoly over violence, a functioning state must be able to enforce laws, secure property rights and enforce contracts, as well as possess the fiscal capacity to raise revenues and provide public goods. If it does not, a contradiction emerges between the de jure and de facto functions of the state, which Ghani and Lockhart (2008) label the sovereignty gap. A modern state must also be able to provide a wider range of public goods (health and education for example), in addition to a capacity to regulate and manage markets. The list grows longer with economic progress - more affluent nations tend to have bigger governments (measured by the share of government consumption in national income), as well as greater capacity to tax (see data in World Bank 2010). Economic decline in failing states severely undermines the state's fiscal capacity, something that makes the state heavily development assistance dependent, which further diminishes state capacity. Furthermore, a 'failing' state's ability to guarantee personal security, property rights and laws is often limited, leading to the privatisation of violence between predatory and defensive elements within society. All these factors combine to produce a degenerating social contract, where individuals rely on kinship based groups and local warlords for security and the provision public goods, heightening civil war risk as society descends towards an anarchical, Hobbesian state of nature.

\subsubsection{Globalisation and conflict}

In developing countries deemed to be successes in terms of achieving economic growth and their participation in the globalised economy, economic progress can bring about its own conflictive tendencies even when the state is not fundamentally threatened by outright civil war. Some of these conflicts take the form of highly localised revolts in 
small pockets of the nation state, and may even escape serious international scrutiny, as the country as a whole is deemed to be making progress. Countries that are growth or human development successes on aggregate may still contain regions where extreme disadvantages and deprivation persist.

Some of the world's economic success stories, in terms of growth, are highly globalised in terms of their participation in international trade and financial flows. These countries, mainly in East Asia (and also India), have done well, but the cost has been greater inequality, particularly the widening gap between skilled and unskilled workers (Mamoon and Murshed 2008), and the increased marginalisation of informal sector workers and landless labourers. The Heckscher-Ohlin-Samuelson (HOS) theory of trade informs us that after an expansion of trade, the factors of production engaged more intensively in the exportable sector will witness a rise in their remuneration. This is because the exportable sectors of the economy expand after increased international trade, while the import-competing sectors contract. If there are factors of production, say certain types of workers, specific to the contracting sectors, many of these individuals will become part of the unemployed unless they can re-equip themselves into newer occupations. It is immediately apparent that globalisation produces winners and losers, and in many instances the losers of increased trade or globalisation demand protection. The absence of these counteracting policies can encourage revolt, including violent protest that undermines development, even if it is not a serious challenge to the state of the type that produces what is commonly understood to be state 'failure'. For example, the commercial extraction of forestry and mineral resources in India, along with the historical marginalisation of certain ethnicities, have fuelled Maoist insurgencies in that country.

Rodrik (1998) pointed out that more open economies generally tend to have bigger governments. The larger size of government relative to national income is predicated on the need for the state to provide a form of insurance or social safety net against the temporary adverse economic shocks that tend to strike these more open economies with greater frequency, some of which are purely external to the country. For example, the rise in global food and essential fuel prices sparked off revolts in many parts of the world, especially in food and fuel importing developing countries. Shifts in food and fuel prices may also have even been partially responsible for the Arab Spring protests in 2011. By contrast, the Chinese government's fiscal boost following the growth slowdown in the wake of the 2008 recession may have staved off social unrest. Similarly, the achievement of macroeconomic stability may produce conflict. For example, international financial markets require the smooth servicing of a country's external debt, but debt servicing may require belt tightening in terms of competitive devaluation (which raises the cost of imported food and fuel), as well as government spending cuts. This can lead to mass protest and riots. There is thus a trade-off between macroeconomic and political stability (Boyce 2007).

\subsubsection{Prosperity and violence}

More generally, historical accounts suggest that violence and increasing prosperity initially go hand in hand in the early stages of development, but decline thereafter (Bates 2001). Traditional societies may have rules and norms that manage violent behaviour, even making peaceful dispute settlement self-enforcing. An increase in prosperity may 
encourage predatory behaviour in the form of private violence by the less fortunate, or group violence if the collective action problem is resolved. Once growth progresses further, violence must decline to sustain the security of investment, and the state has to perform regulatory and security provisioning functions. Increasing violence may be symptomatic of the return of privatised social violence, precipitated by frustration spawned by greater awareness in the midst of the lack of commensurate individual (rather than national) progress. Gurr's (1970) notion of relative deprivation argues that when people perceive that they have less than their just deserts, they will revolt. This is more likely to occur when the general or average level of prosperity is increasing, but some groups are left behind, as is often the case following globalisation led growth.

Another issue that may produce violence in developing countries, but has received scant attention, is the growing inequality between the richer and poorer nations of the world. Milanovic (2011) demonstrates that the growth effort required for poor countries to catch up, including that for fast growing emerging economies like India, is much greater than expected. Secondly, individual positions in a global income distribution are much more determined by domicile (the country where you work) rather than socioeconomic class or occupation. For example, the income inequality between two similarly qualified doctors working in Britain and Zimbabwe may be greater than the measured inequalities that exist within a single nation state. In an era of widespread informational dissemination about more affluent life styles, disparities between nations may encourage people disaffected by this global inequality of opportunity to revolt against their government's failure to deliver a higher and fairer standard of living. The draconian restrictions on international migration do not help to resolve these tensions.

\subsection{NATURAL RESOURCE ENDOWMENTS AND CIVIL WAR}

The scarcity of resources such as land or water for agriculture or pastoralism may produce conflict. During the last decade, however, the fact that economic dependence on primary goods exports enhances conflict risk became an oft-cited finding in the rational choice literature in conflict studies. Collier and Hoeffler (2004) thus argue that the abundance of natural resource rents is said to lead to the greed motivation for conflict, the idea being that it is easier to purloin profits or rents associated with the production of natural resource based commodities. This result has been subjected to a great deal of scrutiny, and as a consequence has not emerged unscathed. The fact that this simple assertion, based on a non-robust statistical association, needs to be nuanced is now widely accepted; see Murshed, 2010, chapter 3 for a detailed review.

A major concern with the Collier and Hoeffler (2004) econometric work was that it conflated all primary goods exports (the independent variable was primary goods exports as a share of national income) with key lootable or obstructable resources, and excluded illegal substances. To be a source of conflict a natural resource based product needs to be contestable (Ross 2003); prime examples of these are oil, gas, alluvial diamonds and narcotics bases (coca and poppy). Furthermore, there is a measurement issue: do we take into account the total stock of resources in our measurement of conflict risk rather than flows (indicated by production or exports). Additionally, when we differentiate between on-shore and off-shore oil, alluvial and deep mine diamonds, the conflict risks are greater with both on-shore oil and alluvial diamonds (both are 
more obstructable or lootable). Finally, there are issues with sample size and averaging, rendering the econometric findings of Collier and Hoeffler non-robust to variations in coverage.

The availability of lootable and obstructable resource rents may be a better explanation for the longer duration of civil war rather than its actual onset. Natural resource rents can, in and of themselves, also become a source of grievance leading to war and insurgency if local populations feel that they are not getting their fair share of the proceeds of resource rents. Such is the case in the Niger Delta region of Nigeria. It can also cause secessionist tendencies among relatively rich regions that no longer want to share their wealth with their fellow countrymen, as in the case of Aceh in Indonesia.

The greed motivation for conflict discussed thus far is by no means the only explanation. Aptly titled, the resource curse provides another explanation for conflict. The resource curse argues that the presence of substantial natural resource rents retards development through political economy channels. This has a bearing on resource rents as a potential driver of civil war, as civil war is one (violent) form of competition over the right to control resource rents. In a nutshell, the negative effects of resource rents from a political economy perspective arise when it leads to rent seeking and corruption, both of which have a destructive effect on normal productive investment and hence growth. The key mechanism in the middle which transforms resource wealth and rents to a problematic political economy is institutional quality. Kleptocratic motivations may also lead to the deliberate undermining of the institutions that sustain the social contract mentioned above. The important point is that institutional quality is partially historically determined, but they are equally determined by (or endogenous to) natural resource abundance or dependence.

A related question is what do we precisely mean by institutions. In the literature under review here, institutions pertain to the measured quality of governance, and sometimes to the nature of the political system (democracy, autocracy, anocracy, presidential/prime ministerial systems, constraints on the executive). All of these phenomena are numerically measured in various data sets that code and rank institutional quality. Mavrotas, Murshed and Torres (2011) demonstrate that both point-source (mainly mineral and fuels) and a diffuse (agricultural) type natural resource dependence retard the development of democracy and good governance, which in turn hampers economic growth. In this connection good governance may be more salient for economic growth relative to the quality of democracy.

Auty and Gelb (2001) argue cogently that an abundance of natural resource wealth can make the state and society less benevolent and more extractive compared to developmental states that nurture an internationally competitive manufacturing sector, as in North-East Asia. An abundance of resource rents, especially oil and gas rents, can also retard state capacity, especially fiscal capacity. This is because the state is less reliant on taxes as a source of revenue, depending to some extent on royalties associated with oil and gas. This may have a negative impact on democratic development (Ross 2001), as lower levels of taxation imply less accountable government.

Is it natural resource abundance or dependence which is at issue here? A country may be abundant in natural resources, but may not depend as much on these if it has a diversified economy, compared to undiversified resource dependent economies (referred to as the staple trap by Auty and Gelb, 2001). For example, the United States is abundant in many types of natural resources, but is less dependent on them 
compared to say, Nigeria. The former country mainly exports software based products and services within a global value chain, whereas the latter mainly relies on oil exports. Brunnschweiler and Bulte (2009) reject previous arguments that regard natural resource wealth or dependence as the principal culprit for civil war. They speculate that resource dependence (a reliance on primary goods exports rather than simply having a lot of natural resources) may be a manifestation of the failure to grow and diversify as a consequence of conflict, but it does not contribute directly to conflict.

Both the simple minded greed theories based on purely criminal motivations and naive institutional fundamentalism in relation to natural resource rents and conflict risk need a great deal of nuancing to the individual case under scrutiny, so that the mechanisms that contribute to natural resource rents becoming conflict risk enhancing are properly understood. Among the many factors to be considered are the type of natural resource, measurements of their abundance and the economy's dependence on them, variation in the quality of political institutions, the incentives of rulers and the ruling class, and whether rulers deliberately undermine existing institutions to facilitate their kleptocratic ends.

An important dimension missing from the literature on natural resources and conflict is the individual's motivation to participate or refrain from joining rebellion or violent contests over resource rents. This problem is usually brushed under the carpet, even by those constructing theoretical (mathematical) models of resource driven conflict, by stating that the conflict entrepreneur must satisfy the participation constraints of his soldiers (usually by allowing them to loot). Indeed, many studies have indicated that participation in violence is motivated by the lack of alternative employment opportunities and the lack of human capital (education) with which to make a living. In addition to these extrinsic or pecuniary motivations, individuals are also driven by intrinsic motivations, particularly group grievances. As previously indicated, group identity may be salient to revolt and rebellion. An individual's utility may be related to his group identity, specifically the relative position of the group he identifies himself with in the social pecking order; see Akerlof and Kranton (2000). An individual may derive utility from certain normative forms of behaviour appropriate to his identity but considered deviant by other groups, and may even face sanctions from like-minded group members if he/she deviates from them. Memories of historical injustices can play an important part in forming the group identity. This type of behavioural paradigm may be related to solving the collective action problems alluded to earlier, without which organised large-scale violence is impossible.

\subsection{LOCALISED CONFLICT}

In conflict studies at present there is a need to go beyond the results that emerge from 'averaging' across the world's conflicts typical of cross-national studies, where the cases are extremely heterogeneous because conflicts in different parts of the world are lumped together in a single cross-country econometric exercise, to the analysis of conflict at the more homogenous sub-regional and sub-national levels. The study of local conflicts is very much within the mode of the case study approach. The heterogeneous effects of conflict may extend to different areas of the same country, including rural and urban areas. Therefore, more studies of the drivers and consequences of conflict at a more 
local level within nation states are required. Average results that are determined from a cross-section of countries in various parts of the world, combining Latin America, Africa and Asia, may disguise what is salient to an individual conflict in a region within a country. It is also often misleading, leading to one-size-fits-all types of policy prescriptions that can backfire. For example, environmental conflict between different groups over land, access to water and other natural resource based production inputs yield different results when studied locally or in a large N-country cross-sectional analysis. Environmental factors as a source of conflict are found more significant in local case studies, whereas its importance diminishes when examined through the prism of a cross-country analysis. Moreover, in many large developing countries, systematic internal conflict is highly localised and confined to a few small geographical regions. These do not necessarily seriously undermine the central authority of the state, but continue to retard human development in various pockets, even when the nation as a whole is making progress. The various Maoist insurgencies in India are a case in point.

A variety of methodologies can be employed to study local conflicts. One such technique is based on the analysis of household surveys. These are standard nowadays, and among other things are used to gauge information on household consumption, living standards and other socio-economic information, including questions about identity. They are particularly useful in post-conflict settings in order to garner information on household coping strategies, livelihood investment decisions, as well as the salience of group identity based grievances in provoking future conflict. There have been calls for a more microeconomic approach to the study of conflict (for example, Verwimp, Justino and Brück 2009), and this essentially implies studying conflict in particular localities. Another technique, used in geography, involves GIS mapping of conflict flashpoints and the exact location of contested natural resource endowments. For example, Cederman, Weidmann and Gleditsch (2011) find that group differences in per-capita income along with political exclusion help to explain conflict.

Local level household surveys permit the gathering of information on aspects of cognitive psychology involving trauma and some of the tenets of behavioural economics in situations where there has been violence and conflict. This is important, because household preferences may not be exogenous but endogenous to previous experiences, including the trauma of conflict. For rural households and self-employed informal sector workers, consumption and production decisions are inseparable because production and consumption are closely related. Therefore, these households are used to risky decisions and outlays. The presence of armed conflict can add new dimensions into these risks and uncertainties, depending on the duration and intensity of the conflict, as well as perceptions about conflict re-emerging if it has stopped. Here prospect theory rather than expected utility may be more relevant following the traumas of war (Kahnemann and Tversky 1979). Observed behaviour suggests that an uncertain prospect is often judged by the overall prospect of loss or gain rather than its strict pecuniary expected value; risk taking (rather than risk aversion) may be a more common psychological response from positions of loss.

Prospect theory represents a departure from expected utility in that it is a twostage process, and risky ventures are weighted not just by (subjective) probability of the different risky states, but by a more complicated 'decision weighting' process. The first stage of the decision involves an editing phase where a reference point is chosen to evaluate the likely effect of the actual risky investment and framed in terms of specific 
aspects of the highly valued prospect or outcome by the decision maker. In the second stage of evaluation, when the household decides on its type of investments, it may take more risks if the risky project has a high enough decision weight in comparison to the less risky alternative. Decision weighting is related to the probability of an uncertain project bearing fruition, but it also includes the subjective desirability of the outcome, a property that alters less readily in the mind than the more objective probability of success. The point being that taking on more risks is understandable if there is a substantial chance that such investments will lead to the recuperation of particular erstwhile losses. Consequently, a strong desire to retrieve a valued past state as a primary response to trauma and loss may occasionally lead to increased risk taking after experiences of violence. Clearly, there will be some heterogeneity in individual responses to violence; not all traumatised individuals will become risk takers. Subjective perceptions regarding violence are endogenous to the lingering effect of actual past experiences. In decision-making involving the future, these perceptions may impact more on current individual preferences and choice. Individual households may not just be passively coping with the events around them, but can actively react to these events in order to re-shape their future.

The points enumerated thus far in this section pertain to individuals and households. For the study of local conflict, however, the knowledge of local conditions also matters, and these will differ from national level averages and institutions. Local institutions that are of importance are not the national quality of governance and democratic functioning, but instead local politics and social capital, especially the extent of bridging social capital (if any) between antagonists. Furthermore, local economic conditions are crucial to the conflict, and these include group inequalities, poverty profiles, and the abundance or scarcity of agricultural inputs (resources). Above all, what is salient to a local conflict is whether different ethnicities compete over the same resource, or whether they participate in complementary economic activities. For example, conflict risk is much greater when different ethnicities are engaged in the same activity, say agriculture, than when one group are principally farmers and the other retail traders.

Another point of interest in the analysis of local conflict is decentralised governance, particularly fiscal federalism (Murshed 2010). Fiscal federalism devolves government expenditure decisions and/or revenue raising powers to sub-national entities. The revenue aspect may be important, particularly for regions with natural resources as is the case in Indonesia or Nigeria, because it appeases local discontent about regionally generated revenues being siphoned off to central government. Other regional governments may be better able to raise local revenues or even conduct their own borrowing. Decentralisation may also increase the utility of regions able to make their own decisions about local public expenditure. It is therefore important to distinguish between the revenue and expenditure side of fiscal decentralisation and its relation to conflict.

On the expenditure side, a citizen is normally indifferent to which layer of government provides public goods, as long as provision is adequate. Citizens may care about the type of provision in some instances, say about what languages are taught in school, which might vary over different education authorities. Thus, expenditure priorities are subject to political processes. Consequently, it may matter which executive authority (regional or national) or what legislature (regional or national) legislates on spending 
priorities. Related to this is the theory of club goods. As the name suggests, club goods are excludable and voluntary. Only members can benefit from the club good. As with a public good, members of a club share, so the rule for the optimal provision for public goods also applies. The important point here is that many government services are closer to the characteristics of club goods as opposed to pure public goods, particularly at the local level. Furthermore, an outcome closer to the club goods optimum may be achieved with greater local control over public expenditure. Since this implies volition, it may be conflict reducing.

Poorly conceived fiscal federalism or the failure to adapt federalist rules to new and emerging situations (such as natural resource discoveries or debt burdens) can exacerbate latent conflictual tendencies in federations. In countries where minorities are geographically dispersed, other forms of functional federalism or power dividing mechanisms are necessary in addition to fiscal federalism. Fiscal decentralisation might work better in middle income countries with greater revenues to spend on public goods, and in countries where resource rich regions demand financial autonomy. Indeed, Tranchant (2008) empirically demonstrates that fiscal federalism is more successful at reducing conflict risk in countries with superior institutions using the international country risk guide (ICRG) data, implying that better institutional quality means the country has superior governance and more durable political institutions. In particular, nations with malfunctioning institutions often have weak central governments, which encourages violent challenges to it, as well as scenarios in which fiscal decentralisation fails to mollify potential rebels.

\subsection{SECTARIAN AND CIVILISATIONAL CONFLICT}

Rational choice approaches to conflict mainly focus on the material (economic, political) basis for conflict, as well as its material effects on society. There is relatively less on intrinsic and identity-based motivations for conflict - a group cause based on identity that individuals identify with and can fight for. One reason for this is that rational choice approaches often ignore history, concentrating on more immediate circumstances. Secondly, there is relatively less literature originating from the economics discipline on two forms of low intensity violence: civilisational or cultural conflict and sectarian violence. This is perhaps because neither truly undermines the existence of the state. In sectarian conflict the focus should be on individual choices to join or refrain from violence, rather than collective or group choices, as these modes of sectarian conflict are relatively less pre-meditated.

Sectarian violence between religious groups characterises several developing countries: Hindu-Muslim violence in India, and Christian-Muslim violence in Indonesia and Nigeria. These outbreaks are highly localised - confined to certain regions of large countries - and do not fundamentally undermine the state. The state itself is not a target of the violence, unlike in the case of civil war; only localised state functionaries are found to be actors in this form of violence. India has a longer history than either Nigeria or Indonesia in this regard. Brass (2003) points out that Hindu-Muslim sectarian violence, known as communal rioting in India, is not as spontaneous as we are led to believe, but is very much a part of the political process in India - particularly during the rise of Hindu fundamental parties in the post-Nehru era. He also contends that, since 
Muslims are a regular target of such attacks, the attacks should be more appropriately termed as pogroms rather than spontaneous rioting. The easing of sectarian conflict in developing countries requires poverty reduction and the stemming of the inequalities produced by economic globalisation. Declining poverty raises the attractiveness of peaceful income, rather than the earnings related to loot and violence. The inequality produced by globalisation produces richer sectarian individuals who fund communal causes, leaving it to their poorer brethren to enact the violence. Hence, social safety nets and the public provision of health and education that combat poverty and lower inequality are essential. Localised institutional functioning also needs addressing. This includes the often virulently sectarian outlook of local governments, such as the government of the Indian state of Gujarat. Furthermore, getting to know the "other" by way of increasing the bridging social capital between communities is also important in building peace, as are the advantages of peaceful income to individuals.

\subsection{CONCLUSIONS}

In the last decade, our understanding of the processes underlying mass violent internal conflict has progressed to incorporate a greater variety of economic, political and social factors, as well as institutions of conflict management. Methodological differences remain, but analysts of conflict have achieved a degree of consensus that violent internal conflict is mainly brought about by relative deprivation and/or the competition over resources. These tendencies, however, can either be mitigated by good institutional structures of governance or exacerbated by malfunctioning and degenerating institutions (the social contract). Indeed, one of the more robust statistical findings regarding conflict risk is that low per-capita income increases the likelihood of war. This is because lower per-capita income implies greater poverty, along with a greater probability of institutional malfunctioning.

A well functioning social contract manages potential conflict and discourages violent challenges to the state by non-state actors. There are also well known quantitative studies that cover all countries in the world and regard the determinants of internal conflict. The general propositions that emerge are informative, stressing on the one hand the presence of opportunity and feasibility in forming rebel movements, as well as the failure of state capacity to restrain these tendencies. On the other hand, it has long been recognised that deprivation produces rebellion. This relates to the differences between what people have in terms of tangible socio-economic indicators (income, assets including land, access to common property resources, access to public services, education and health), and what they think are their just deserts. If they have less, they may be inclined to rebel. Furthermore, in the absence of corrective policies, this is more likely to cause conflict in more ethnically fragmented societies. The moot point here is whether we are more concerned with individual relative deprivation or ethnically based group relative deprivation as a source of conflict risk.

Yet a variety of lacunae remain in conflict studies. First and foremost is the complex relationship between development and economic progress and conflict risk. Both severe underdevelopment and rapid economic progress can produce conflict risk. The former is associated more with the risk of civil war, while the latter usually associated with mass violent protest and localised rebellion that does not fundamentally 
undermine the position of the state. Attention has to be focused on the distributional consequences of growth. New sources of tension arise in our globalised world because of rising food and fuel prices that intensify existing grievances against the state, burdens of servicing international debt, and through the relative deprivation felt because of the ever-widening gap in living standards between rich and poor countries. Secondly, we have the non-linear impact of increased democratisation on conflict risk. Mature democracies are usually more peaceful, but democratic transitions enhance the chances of violent conflict. This means we have to have a nuanced take on the role of institutions, eschewing the naïve institutional fundamentalism that pervades the contemporary mainstream thinking about long-term development. Thirdly, greater emphasis has to be put on detailed case studies of local conflict. This means a deeper understanding of local economic conditions and social capital. Household surveys, if intelligently designed, can also yield deeper psychological insights on how the trauma of violence affects economic behaviour, as well as gauging the contribution of group identity and group grievances to any future conflict risk. The role of intrinsic motivation in joining movements, particularly the part played by an individual's identification with the cause of a disadvantaged group that he belongs to, deserves much more than the scant and passing attention that it has hitherto received in the rational choice literature on conflict. The study of sectarian (or communal) conflicts in countries such as India, Indonesia and Nigeria deserves more sophisticated study.

In the ultimate analysis, conflict resolution has ubiquitously required justice, and not just the justice that is in the interest of the stronger. In this connection a few words about the new liberal imperialism, which for example favours regime change by direct action, are in order. Just as in the 19th century, the excuse of civilizing the backward is being increasingly used to justify direct intervention in developing country conflicts. Despite the rhetoric, there is a great danger that these actions are much more in tune with the old imperialist objective of controlling the non-European world to the advantage of Europe (the present West), or at the very least in the spirit of colonialism's misplaced 'white man's burden' aim of civilizing the uncivilised; something that has been historically such a resounding failure.

\section{REFERENCES}

Akerlof, G. and R. E. Kranton. 2000. Economics and Identity. Quarterly Journal of Economics 115, no. 3: 715-753.

Auty, R. M. and A. G. Gelb. 2001. Political Economy of Resource Abundant States. In Resource Abundance and Economic Development, ed. R. M. Auty, 126-44. Oxford: University Press.

Bates, R. H. 2001. Prosperity and Violence. New York: Norton.

Boyce, J. 2007. Public Finance, Aid and Post-Conflict Recovery. Working Paper 2007-09, University of Massachusetts-Amherst.

Brass, P.R. 2003. The Production of Hindu-Muslim Violence in Contemporary India. Seattle: University of Washington Press.

Brunnschweiler, C. N. and E. H. Bulte. 2009. Natural Resources and Violent Conflict: Resource Abundance, Dependence and the Onset of Civil Wars. Oxford Economic Papers 61, no. 4: 651-674.

Cederman, L.-E., N. Weidmann and K.-S. Gleditsch. 2011. Horizontal Inequalities and Ethnonationalist Civil War: A Global Comparison. American Political Science Review 105, no. 3: $478-495$. 
Collier, P. and A. Hoeffler. 2004. Greed and Grievance in Civil Wars. Oxford Economic Papers 56, no. 4: 563-595.

Collier, P., L. Elliot, H. Hegre, A. Hoeffler, M. Reynal-Querol and N. Sambanis. 2003. Breaking the Conflict Trap: Civil War and Development Policy. Oxford: Oxford University Press.

Fearon, J. and D. Laitin. 2003. Ethnicity, Insurgency and Civil War. American Political Science Review 97, 1: 75-90.

Galtung, J. 1964. An Editorial. Journal of Peace Research 1, 1: 1-4.

Ghani, A. and C. Lockhart. 2008. Fixing Failed States. Oxford: University Press.

Gleditsch, N. P. 2008. The Liberal Moment Fifteen Years On. International Studies Quarterly 15, no. 4: 691-712.

Gurr, T. R. 1970. Why Men Rebel. Princeton: Princeton University Press.

Hegre, H., T. Ellingsen, S. Gates and N. P. Gleditsch. 2001. Towards a Democratic Civil Peace? Democracy, Civil Change, and Civil War 1816-1992. American Political Science Review 95, no. 1: 17-33.

Hobbes, T. 1651. Leviathan. Reprinted 1998, Oxford: World Classics.

Homer-Dixon, T. F. 1999. Environment, Scarcity, and Violence. Princeton: University Press.

Kahneman, D. and A. Tversky. 1979. Prospect Theory: An Analysis of Decision under Risk. Econometrica 47, no. 2: 263-292.

Kant, I. 1795. Perpetual Peace and Other Essays on Politics, History and Morals. Reprinted 1983, Indianapolis: Hackett Publishing.

Mamoon, D. and S. M. Murshed. 2008. Unequal Skill Premiums and Trade Liberalization: Is Education the Missing Link? Economics Letters 100, no. 2: 262-266.

Mavrotas, G., S. M. Murshed and S. Torres. 2011. Natural Resource Dependence and Economic Performance in the 1970-2000 Period. Review of Development Economics 15, no. 1: 124-38.

Milanovic, B. 2011. The Haves and the Have Nots. New York: Basic Books.

Murshed, S. M. 2008. A Note on the Interaction between Identity Based Fear and Hatred. Peace Economics, Peace Science and Public Policy 14, no. 1, article no. 5.

Murshed, S. M. 2010. Explaining Civil War: A Rational Choice Approach. Cheltenham: Edward Elgar.

Olson, M. 1965. The Logic of Collective Action. Cambridge MA: Harvard University Press.

Olson, M. 1996. Big Bills Left on the Sidewalk: Why Some Nations are Rich, and Others Poor. Journal of Economic Perspectives 10, no. 1: 3-24.

Rodrik, D. 1998. Why do More Open Countries Have Bigger Government. Journal of Political Economy 106, no. 5: 997-1032.

Ross, M. 2001. Does Oil Hinder Democracy. World Politics 53, no. 3: 325-61.

Ross, M. L. 2003. Oil, Drugs and Diamonds: The Varying Role of Natural Resources in Civil Wars. In The Political Economy of Armed Conflict: Beyond Greed and Grievance, ed. K. Ballentine and J. Sherman, 47-70. Boulder, CO: Lynne Rienner.

Sen, A. K. 2008. Violence, Identity and Poverty. Journal of Peace Research 45, no. 1: 5-15.

Stewart, F. 2000. Crisis Prevention: Tackling Horizontal Inequalities. Oxford Development Studies 28, no. 3: 245-62.

Tilly, C. 1998. Durable Inequality. Berkeley: University of California Press.

Tranchant, J.-P. 2008. Fiscal Decentralization, Institutional Quality and Ethnic Conflict: A Panel Data Analysis, 1985-2001, mimeo.

Verwimp, P., P. Justino and T. Brück. 2009. The Analysis of Conflict: A Micro-Level Perspective. Journal of Peace Research 46, no. 3: 307-314.

World Bank. 2010. Financial Structure and Economic Development Database. 


\title{
How natural is natural? Seeking conceptual clarity over natural resources and conflicts
}

\author{
Marcel Rutten' \& Moses Mwangi ${ }^{2,3}$
}

\begin{abstract}
Several schools of thought across scientific disciplines have dealt with the phenomenon of conflicts over natural resources. This has enriched the debate but likewise has also blurred the discussion especially as a result of the generic use of some concepts such as natural resources. This chapter seeks insights in some of these conceptual misunderstandings especially towards the use of the word natural in resources. Examples are given how these varying understandings impact the way different scholars include or exclude certain kinds of natural resources. Furthermore, attention is devoted to work conducted by environmental scientists, having experienced similar problems within their own discipline, in building a model that aimed to set a standard in their field. This framework is elaborated upon by the authors following a political economy angle in an attempt to widen it to the conflict context. The result is an analytical model that underlines attention for history and different geographical scales of analysis. The importance of the role of politics and a globalised world in understanding natural resource conflicts is also stressed. An example from Kenya shows that, among others, political aspects, at some time in the course of development of the conflict are likely to come into play and should be included in any thorough understanding of conflicts over natural resources.
\end{abstract}

Keywords Natural resources, conceptual definition, conflict analysis model, role of politics, Kenya.

\section{I INTRODUCTION}

Researchers use conceptual models to simplify complexity and seek causality between variables. Conceptual clarity is a prerequisite for unravelling complex situations. In this chapter, attention will be devoted to the two concepts all of the contributors to this

\footnotetext{
${ }^{1}$ Senior Researcher at the African Studies Centre. Leiden and Radboud University, Nijmegen, Netherlands (Corresponding author: m.rutten@fo.nl)

${ }^{2}$ South Eastern Kenya University College (SEKU), School of Water Resources and Science and Technology, Kitui, Kenya.

${ }^{3}$ The authors want to thank Halakhe Waqo, Roel Slootweg, Peter Kuyan and the editors for information and comments.
} 
book deal with: natural resources and conflict. This chapter will first present how different schools of thought and groups of researchers differ in the operationalisation of these concepts. It is argued that these varied approaches impact upon theory building and possess varying explanatory strengths. Examples will be drawn from pastoralist societies and from insights as they are developing in the CoCooN-funded research project on competing claims over natural resources in East Africa's drylands. ${ }^{4}$ Subsequently, this chapter suggests an alternative and more appropriate framework for conflict analysis over natural resources.

Finally, a case study is presented that discusses a conflict over the exploitation of gypsum (a soft sulphate mineral used for fertilizers) and marble mining. On the surface, this example seems to be simple and straightforward. However, upon delving deeper, the case shows a high degree of complexity and intricate variety of causes. It underlines the need for those studying natural resource conflicts to apply a historical analysis while taking into account the political economy of the specific context.

It is hoped that this contribution will assist in overcoming some of the distorting effects of ambiguous conceptual use. The ultimate aim is to advance the debate on conflicts and natural resources.

\subsection{LACK OF CONCEPTUAL CLARITY}

In 2010, a special issue of the African Journal on Conflict Resolution was published by the African Centre for the Constructive Resolution of Dispute (ACCORD). The issue focuses on environmental conflicts (Bob and Bronkhorst 2010), and identifies the following types:

1 Biodiversity conflicts - conflicts between people about wildlife or other aspects of biodiversity. This includes conflicts relating to conservation of protected areas and indigenous knowledge linked to natural resources.

2 Coastal zone conflicts - conflicts in these geographical zones could develop from a combination of other types of conflicts.

3 Conflicts disproportionately affecting women - e.g., conflicts over land are thought to hit women in particular.

4 Conflicts about air quality and noxious pollutants - considered to be a key type of environmental conflict characterised by both legal and violent battles.

The list above presents a rather puzzling categorisation of environmental conflicts. It lumps a specific natural resource together with particular characteristics of a conflict, such as the geographical location (coastal zones) or the most affected stakeholders (women). It also differentiates land and water from the environment and, as a consequence, distinguishes environmental conflicts from conflicts over land and water.

A broader review of existing academic and non-academic literature on natural resources and conflicts highlights a generally ambiguous and confusing application of

\footnotetext{
${ }^{4}$ The full title of the project is 'Land grab and dwindling water resources: reconciling competing claims and conflicts over natural resources in Africa's dry lands, specifically Kenya.
} 
these concepts and suggests the need to search for more conceptual clarity. ${ }^{5}$ The various paradigms used within and between disciplines partly explain this ambiguity concerning the conflict-resources nexus. Contributing to the confusion is the phrasing used by non-academic parties, including governmental and non-governmental institutions.

For a thorough understanding of the conflict-natural resources nexus, we need to append adjectives to these terms - e.g., renewable, biotic and removable for natural resources, and latent, manifest, local, and cross-boundary, among others, for conflicts. A next step is to establish the trends in either abundance or scarcity of a specific natural resource that stand at the centre of a conflict. We consider a historical perspective and political economy analysis to be the most rewarding, especially if we apply a process-oriented perspective of natural resource analysis. Barrow (1999: 5) indicates that environmental management is an "approach that goes beyond natural resource management to encompass the political and social as well as the natural environment. It is addressed with questions of value and distribution, with interpersonal, geographic and intergenerational equity." Before we elaborate this line of thought in more detail, let us first scrutinise the concept of natural resources as it has been used in recent academic and non-academic publications. In the last section we will summarise our approach schematically in a conflict-resources framework.

\subsection{WHAT ARE NATURAL RESOURCES? A LITERATURE REVIEW}

The term natural resource, like environment, is mostly used in a generic way. We are all supposed to understand what is meant by it and the concept is seldom specified. A clear example of this is the book, World Resources - The Wealth of the Poor: Managing ecosystems to fight poverty published by The World Resources Institute (2005). In this book of almost 300 pages, the meaning of community-based natural resource management, resource access and resource degradation is explained, but no definition of natural resource is ever provided. Likewise, the recently established "Natural Resource Charter" (also see www.naturalresourcecharter.org), a Paul Collier-led Oxford University initiative backed by policy makers, leaves us in the dark when it comes to defining a natural resource. The Charter has been devised with the intention of being used as an international tool to foster the sustainable implementation of the transformation of poor economies exploiting their natural resources. It defines 12 precepts to guide the governments and societies of resource rich countries in the generation of economic growth that promotes the welfare of the population in an environmentally sustainable way (NRC 2010: 1). Although the term 'natural resource' is mentioned 34 times, the Charter provides no precise definition. Reading in between the lines of the Charter, it seems that it is limited to non-renewable extractive resources such as oil, gas, other minerals and metals, thus leaving aside resources such as forests, pastures and water, among others (NRC 2010).

The 1999 discussion paper entitled, Exploring understandings of institutions and uncertainty: new directions in natural resource management, is yet another publication that fails to define the term natural resources. The paper, produced by the IDS -Sussex

\footnotetext{
${ }^{5}$ Frerks (2007) sketched some of the building blocks in the resources-conflict knowledge framework and the accompanying complexity, see also Chapter 2 of this volume for an update.
} 
environment group, points to the poorly researched role of institutions in natural resources management (see Mehta et al. 1999), and focuses on a handful of case studies: (grazing) land, water, trees. Following these discussions, the paper concludes that natural resources have both a material and a symbolic dimension. ${ }^{6}$ As noted, we are again not offered a precise or concise definition of natural resources. The IDS scholars do, however, rightly stress that resources have various and often conflicting uses and meanings for different stakeholders (Mehta et al. 1999: 33-34).

Without a clear definition of natural resources in the scholarly material, let us turn instead to a dictionary and encyclopaedia for assistance. The Oxford Dictionary (2013a) describes natural resources as follows: "materials or substances occurring in nature which can be exploited for economic gain." This explanation is a rather limited view that denies the symbolic dimension of natural resources pointed out by the IDS group. Wikipedia, on the other hand, provides a more elaborate definition:

[n]atural resources are materials and components (something that can be used) that can be found within the environment. Every man-made product is composed of natural resources (at its fundamental level). A natural resource may exist as a separate entity such as fresh water, and air, as well as a living organism such as a fish, or it may exist in an alternate form which must be processed to obtain the resource such as metal ores, oil, and most forms of energy.

This definition seems straightforward. However, do academics and policy makers follow a clear and unified categorisation of natural resources or are they engaged in another 'Tower of Babylon-like' conversation when discussing natural resources? Let us inspect some of the key publications that deal specifically with natural resources (and conflicts) in Africa and beyond.

In Nature Wealth and Power - Emerging Best Practice for Revitalizing Rural Africa, a study commissioned by USAID (2002), a group of scholars presents lessons learned from 20 years of experience in natural resource-based development. They state that while natural resources are a major source of wealth and power in Africa, they are also a key to rural development and good governance. Natural resources - land, minerals, forests, wildlife and water - are central to the livelihoods of $70 \%$ of the population and dominate some African economies. It is interesting that this author group restricts living organisms to wild animals only.

In Entitlements to natural resources - contours of political environmental geography, Dietz (1996: 33) provides a short and simple definition: "Nature becomes a natural resource whenever people relate to nature, so it is a resource by social definition. It is not their mere availability or their potential use that makes these elements of nature a resource, it is their actual use by and impact on humanity." He continues by summarising a list of natural resources: land (including soil resources, but also solid wastes), minerals, water, air, energy, flora and fauna (including the domesticated animals and plants). Note that unlike the USAID study, Dietz (1996) includes domesticated animals as a natural resource. Dietz (1996) acknowledges the difficulty in

\footnotetext{
${ }^{6}$ Rutten (2010) also stresses this non-physical dimension of land when pointing at the view among several African communities that land is a resource that is inherited from the older generation and has to be passed on to the younger generation.
} 
drawing lines. As we will show later, this ambiguity is an important pitfall in theorising natural resource conflicts.

In Conflicts over land \& water in Africa, Derman et al. (2007) highlight two natural resources: land and water. In addition, they attempt to define natural resources and, in doing so, highlight their theoretical process. They state:

natural resources are [..] generally provided by nature rather than produced by humans. Some are renewable, and can be maintained at different stocking levels depending on management and use. [..] Broadly speaking, however, natural resources are in absolute limited supply, constrained by available areas and volumes of land, water and air and they will tend to become scarcer through time as global population increases (Derman et al. 2007: 3).

The above thinking places Derman et al. in the neo-Malthusian school of thought. Natural resources are limited and a growing demand when population numbers increase will result in scarcity. ${ }^{7}$ Like many before them, the definition of what natural resources really are remains somewhat ambiguous, hampering any attempt at firm classification. Furthermore, like Montani (1987), they define natural resources as commodities that are useful, scarce and not produced by labour. Montani (1987) seems to follow Marx's view on the usefulness of resources as one disentangled from the scarcity concept. The symbolic element of natural resources is also not part of this school of thought.

Some scholars argue that Marx hardly dealt with natural resources. This claim is challenged by Perelman (1975), who refers to Marx's labour theory of value. Marx's model begins with a period of rapid depletion of resources, followed by a period of investment in developing resources in which technical advances increase the efficiency of producing natural resources. In other words, a natural resource might retain its quality, albeit with requisite human and capital interference.

Mazor (2009) has attempted to define natural resources from a liberal perspective. Referring to liberal thinkers such as Locke and Mill, he aims to construct a theory of natural resource property rights starting from the principles of equity, neutrality and freedom. He diverts, however, from a more general right-libertarian argument. Instead of holding that natural resources are useless without some form of human labour, Mazor (2009) contends that some portion of the value of natural resources can be attributed to the presence of the natural object itself. Mazor (2009: 40) calls a resource natural if it has not been created or significantly altered by human beings. Land, water and oil in pristine condition are all examples of natural resources. Wild animals (e.g. fish in the sea) are also natural resources, but human bodies and any parts thereof are not. Mazor (2009) acknowledges grey areas such as primates and intelligent mammals like dolphins, but stresses that human beings routinely cultivate, harvest, mine and otherwise transform natural resources in ways that increase their value. The resulting goods, such as irrigated land and captured fish, are not seen as natural resources, but rather as composite goods that require natural resources as inputs along with labour.

\footnotetext{
${ }^{7}$ See also Frerks et al (Chapter 2) where this approach is presented as one of three main schools of thought for explaining the occurrence of conflicts. The other two schools they identify are the neoclassical economist approach stressing the role of institutions and innovation; and a distributionist approach that highlights the maldistribution of resources and wealth.
} 
He refers to composite goods for which natural resources constitute a significant input as developed natural resources. Moreover, because human activity might also decrease the value of natural resources - e.g. pollution can cause a reduction in the value of otherwise pristine land, water and air - Mazor (2009) labels resources with values reduced by human activity as degraded natural resources.

So there we are: composite goods and degraded natural resources are the terms to be used the moment labour or human activities take away the virginity of the natural resource. Using an instrumentalist approach, natural resources of interest are those that are valuable or 'useful for the attainment of human goals'. Having significantly reduced the number of 'pure' natural resources, Mazor (2009: 41) proceeds by defining a resource as "anything that is useful for the attainment of human goals." That means that he excludes the so-called inherent value of a natural resource, at least for some of the natural resources - e.g. animals and landscapes. This leaves only a limited number of resources that can be considered useful as well as natural - e.g., oil in the Arctic seabed.

Interesting in Mazor's approach is the centrality of the issue of property rights in developed and degraded natural resources. He questions, "Who (if anyone) was justly entitled to develop and degrade them in the first place. The answer to this question may have important consequences for how we view current property rights in developed natural resources" (Mazor 2009: 42). Especially in relation to an understanding of why and how conflicts over natural resources erupt, the issue of property rights deserves special attention.

According to Kok et al. (2006: 8), “a large proportion of Africans are dependent on natural resources and the environment to subsist." Continuing, they explain that the latter of these two assets "is the foundation of livelihoods based on subsistence and commercial farming, animal husbandry, trade and mining. These activities are inextricably linked to the availability of natural resources and the sustainable management of those resources" (Kok et al. 2006: 8). The authors stress that natural resources and the environment are different concepts. Natural resource factors are defined as nonrenewable extractable resources such as minerals, oil and diamonds. Environmental factors are categorised as renewable sources of livelihood that allow a person to make a living. Environmental factors such as land, water, fish stocks and timber may not be accessible to all people in a geographical area, and may be degraded by use or mismanagement.

Both Mazor (2009) and Kok et al. (2006) acknowledge the need to relate natural resources to their utility for making a living, but they use fundamentally different concepts of natural resources. Where Mazor (2009) would dismiss the distinction between natural resources and environmental factors since both are linked to people's livelihoods, the distinction serves a specific purpose for Kok et al. (2006). For the latter, it allows the distinction of two categories of motivations for conflicts, also known as the concept of greed (linked to natural resources) and grievance (linked to environmental factors). In addition, they indicate an overlap between greed and grievance similar to an overlap between environmental factors (land, water) and natural resources (minerals, metals, diamonds). In this overlap, factors such as timber, oil and fish feature prominently (see Kok et al 2006: 14). The advantage of this approach is that it recognises specific qualities of the resources and the extent to which these explain certain conflict characteristics. 
Idi Brown (2011) discusses the natural resource curse theory and builds upon another categorisation of natural resources, namely point source resources and diffuse resources such as agriculture, fisheries and livestock. She claims, "countries in [Sub Saharan Africa] with rich endowments in oil, precious metals, diamonds and other minerals are notorious for their bad institutions, bleak growth rates and dismal development outcomes. On the other hand, countries with more diffuse resources tend to exhibit a more inclusive and cooperative environment with less corruption and more stable growth rates" (Brown 2011: 2).

We have noted a variety of partially contradictory approaches to conceptualising natural resources in academia as well as wider society. For reasons of order, it may be helpful to make a classification of natural resources based on their origin, stage of development, and renewability. Following these three major aspects, several subclassifications can be created:

1 For origin, it is biotic (e.g., forests, animals, birds and fish but also coals and oil) and abiotic (land, water, air, heavy metals including gold, iron, copper, silver, etc.). The biotic and a-biotic divide is, as we will highlight below, a major cause of confusion.

2 Considering their stage of development, natural resources may be referred to as potential resources, those that exist in a region and may be used in the future; actual resources, those that have been surveyed, are being used in present times, and have had their quantity and quality determined; reserve resources, part of an actual resource that can be developed profitably in the future; and stock resources, those that have been surveyed but cannot be used due to lack of technology e.g., hydrogen).

3 The third aspect of natural resources is renewability:

- Renewable resources are restocked naturally. Some of these resources, like sunlight, air, and wind, are continuously available and their quantity is not noticeably affected by human consumption. Yet many renewable resources do not have such a rapid recovery rate, these resources are susceptible to depletion by over-use.

- Non-renewable resources are those that form over extremely long time periods. Minerals are the most common resource included in this category. From the human use perspective, resources are non-renewable when their rate of consumption exceeds the rate of replenishment/recovery such as fossil fuels. ${ }^{8}$

4 Point source and non-point source resources. Whereas point-source resources are lootable, non-point sources such as farmlands are not that easily taken away (but their produce may be: see also below).

From the above overview of the use of the concept of natural resources in academic and non-academic literature we conclude that a thorough understanding and clear

\footnotetext{
${ }^{8}$ Some resources actually naturally deplete in amount without human interference, the most notable of these are the radio-active elements such as uranium, which naturally decay into heavy metals. Of these, the metallic minerals can be re-used by recycling them. But coal and petroleum cannot be recycled.
} 
typology of the natural resources discussed is a basic necessity and general condition for a thorough and meaningful analysis of conflicts over these natural resources. As a single classification is highly unlikely, scholars should at least indicate their understanding and use of the concept in detail. Let us now turn to the concept of conflicts before we hone in on natural resources and conflicts in Africa.

\subsection{WHAT ARE CONFLICTS?}

The Oxford Dictionary (2013b) defines a conflict as "a serious disagreement or argument, typically a protracted one." Academic definitions are manifold, but let us briefly present some of these views, irrespective of whether they are directly applicable to natural resource use. According to Stephen Robbins (nd) conflicts are "all kinds of opposition or antagonistic interaction between two or more parties." A conflict is usually based on scarcity of resources, power, or social position, and differing value systems. Robbins, a management scholar, distinguishes three phases in the history of conflict theory: traditionalist (19th century up to 1940), behaviourist (1940/50 onwards) and interactionist (1970s onwards). The philosophy towards the acceptance of conflicts in an organisation has changed from zero, to unavoidable, to actually stimulating some kind and level of conflict as it is argued to improve the output and professionalism of the organisation.

Conflict is a major factor in processes of change and transformation. Hence Peil and Oyeneye (1998: 290) remark, "more generally, conflict theorists argue that the pressures for change in society are ubiquitous, as various interest groups struggle for power and resources. Out of conflict, society changes its perceptions about others." The conflict transformation theory argues that parties shift position, set out new goals, new players and new interests come to the fore. Conflict transformation is therefore "a process of engaging with and transforming the relationships, interests, discourses and, if necessary, the very constitution of society that support conflict" (Lederach 2005: 4).

Said et al. (2009) report five ways of dealing with conflicts, ranging from 'avoidance', 'accommodation', 'competition or aggression', to 'compromise' and 'collaboration or problem-solving'. The latter is considered to be the best approach to both resolving a conflict and maintaining relationships in a community. It is acknowledged, however, that this is a lengthy and challenging process. Help may nevertheless come from three sides: customary, national and collaborative systems of conflict management. As we will argue later, however, the geographical scope is broader than is suggested by these three terms. Whether the approach by Said et al. is of value for conflicts over natural resources involving different players holding different levels of financial power, knowledge and political strength, requires further scrutiny.

\subsection{AFRICAN SCHOLARS AND NATURAL RESOURCE CONFLICTS}

Frerks (Chapter 2) summarises the various and changing natural resource conflict discourses that have prevailed over the years. In this section we will turn to some African scholars who have contributed to the debate on natural resources and conflicts. Obi (1997) has criticised some of the modernist neo-Malthusian approaches that fail to 
account for the commodification of resources in Africa and the role played by others, notably international players. "The primary cause of conflict is the dissonance between the modes of production in which Africa is immersed, while population pressure is a secondary source of environmental stress" (Obi 1997: 9-11). Obi is close to suggesting that pre-capitalist societies are resource conflict free by nature. His focus on the west is equally questionable as, in a globalised world, there is a wide range of extra forces active on the African continent (see Box 4.1), including Asian countries (China, India, Malaysia, S. Korea), Brazil, and some African countries (e.g., South Africa, Libya). We should not a priori lump all resource conflicts together and suggest they all have global and commodifying strings attached.

\section{Box 4.I: Intensification of International Players in the Natural Resource Arena}

Increasingly, the latest wave of globalisation, which jump-started after the fall of the Berlin wall, has intensified and widened the multitude of claims in an arena that is no longer local per se. Enabling western consumers to continue a certain level of well-being, i.e., driving cars, enjoying adventurous holidays in far-away countries, roasting beef, eating off-season vegetables and sending flowers to their beloved ones, has an impact on natural resources in developing countries, notably on land and water. Many transnational corporations or newly constructed business ventures have signed contracts to lease land for agricultural purposes. Lately, other players, namely from the Middle East and Asia, as well as hedge funds and other portfolio holders searching for profitable investments, have joined the search for land and water, especially in Africa. These resources are used to produce soya, rice, maize, flowers, oil palm and biofuel to fulfil a demand arising from western, and increasingly eastern, hemisphere consumers.

These new land acquisitions (mostly by way of long term leases, but free hold purchases are also known) sometimes result in arrangements that directly affect the local population's access to natural resources such as trees and grazing pastures. In other instances, water resources are depleted or diverted away over time (Rutten 2008). This also means that a Code of Conduct entailing a single check at the time of purchase of the resource is not good enough, nor is the implementation of legal instruments as a single weapon of defence to improve the resilience of the local agricultural sector. Technological solutions to promote sustainable agriculture, including soil enrichment and revolutionary water harvesting techniques for both the original and especially the new large-scale players, are also needed. Finally, but certainly not least, political and economic power will further determine the outcome for the poorest groups in society. If these mitigation measures fail, open conflict may erupt.

Another African scholar, Gufu Oba, used Homer-Dixon's (1999) resource scarcityviolence model to analyse the drivers of conflicts between ethnic groups that shared the pre-colonial ethnic frontiers of trans-Jubaland/Wajir and competed over water sources during the colonial period in the Northern Frontier District (NFD) of Kenya from 1903 to 1939. Oba (2011) concludes that pre-colonial ethnic conflicts were not induced by 
resource scarcity. Rather, extended periods of peace punctuated by conflicts were associated more with social and political relations. By contrast, the colonial period, with far more restrictive resource access to wells and the grazing lands, resulted in structural changes in resource scarcity. Colonial resource governance was incapable of preventing the threat of migrant pressures for resident populations. Residents were finally displaced and former alliances were broken up. The competition resulted in violent conflicts due to structural changes that altered rights to resources. Oba (2011: 528) argues that "political drivers, in the form of administration of frontiers and control of population movements, and particularly through the transfer of resources from one group to others, created structural resource scarcity." He terms this a 'policy of resource scarcity', and attributes resource governance to the triggering of ethnic conflicts (Oba 2011). In spite of this, Oba (2011) does not reject the Homer-Dixon model. Indeed, transformations in rights, e.g., adjudication of land transforming customary into statutory rights over land, have triggered many conflicts. However, other causes are as important now as in the past (see Box 4.2).

\section{Box 4.2: Natural Resource Conflicts Now and in the Past}

Post-colonial Kenya is littered with rights-related conflicts (e.g., Kajiado District group ranches and the Tana Delta 2001 land adjudication (Kagwanja 2003; Martin 2007; Rutten 2008). Maasai along the Kenya/Tanzania border belonging to the same Matapato section have resource conflicts over access to wells, pastures and schools. Property rights adjustments on the Kenyan side, blocking access to pastures for the Tanzanian Maasai are responded to by denying access to the wells located in Tanzania (although these officially belong to the Kenyans). In reaction, Kenyans block Tanzanian Matapato children as they cross the border to attend Kenyan primary schools.

The Maasai struggled among themselves in the past as well. In the 19th century, prior to the arrival of the British colonisers, the Maasai experienced fierce internal conflicts. These so-called Iloikop Wars were struggles over stock grazing and water points according to Waller (1976: 532). Yet these conflicts were also geared towards breaking the political hegemony of the Laikipiak Maasai. Several other sections and related Maa-speakers, such as the Samburu, joined hands to diminish the Laikipiak supremacy, which came to a complete eradication of this sub-group around the 1870s. This also marked the end of Maasai control over most of their traditional grazing areas in today's Kenya, stretching over a large area as far as the Coast and North of Kenya.

The cause of conflicts - pasture, water and cattle - is also central in the reasoning of Witsenburg and Roba (2007), who, after analysing rainfall data, cattle raids and casualties in northern Kenya, claim conflicts are more severe during the wet season than during a drought. In other words, it is not scarcity but instead an abundance of natural resources that triggers conflicts. Referring to their findings, which appear to challenge Homer-Dixon's framework that violence can be associated with scarcity of resources, Oba (2011: 505) suggests that the violence they observed may "be explained by factors 
that change property regimes of resources such as that enforced by 'new legislation'." Unfortunately Oba (2011) does not further clarify this contention.

We acknowledge that abundance can also trigger conflicts. However, in our view abundance conflicts are not so much between the direct users of these resources, but more likely between players from different backgrounds - e.g., an outsider elite versus a local community whereby certain resources are captured in the hope of huge future profits. One such example is the practice of grabbing land in anticipation of the arrival of international players in agriculture or mining activities. Other issues seem to be at stake that explain the findings of Witsenburg and Roba (2007). First, there are some methodological problems that need to be addressed. These include their definition of drought years, and the use of rainfall/drought years as a unilateral proxy for resource scarcity, while disregarding geographical and temporal variety of the annual totals. For example, using rainfall data for the area of conflict exclusively does not grasp the situation the intruding party might have experienced in their area of origin. In other words, the cause of the conflict, resource scarcity, was possibly across the border in Ethiopia and not in northern Kenya. To grasp the full picture of motives and mobility patterns, more information is needed for each of the clashes as presented by Oba (2011). Similar methodological uncertainties exist with respect to the use of population data for an area that hardly has any reliable data, at least not up until the 1960s. Moreover, without a clear picture of who was fighting and killing who and for what reason, especially if the attackers originated from other districts or countries for which no data of resource availability is provided, we are left in a mathematical exercise that foremost seems to tell us that in periods of abundance of grass and water in a particular area conflicts are higher. Yet abundance of grass and water are synonymous with scarcity of cattle, the ultimate missing link between natural resources and food availability for human beings.

The overview presented by Witsenburg and Roba (2007) does not clarify whether the raids and killings were committed over ownership and usufruct of grazing or water resources, or whether they are an attempt to capture animals to restock one's own herd. As the authors themselves indicate in reference to some of the pastoralists interviewed, it does not make sense to raid livestock in times of stress as the animals are too weak to trek over long distances and the risk of animals dying as a result of continuous drought or lack of resources in the raiders' home area is too high. Witsenburg and Roba's (2007) observation that average and wet years after a dry year do not show an increase in violence makes one wonder if that is good enough to claim that the wet years are not years for restocking. Taking total annual rainfall is far too rudimentary. It would instead be better to look at the occurrence of cattle raids in rainfall periods following a serious drought. Finally, conflicts are mainly reported as interethnic fights, yet it is known that several African (pastoralist) communities are split along (sub)clan and section (geographical) lines. These groups fight over resources at times as well. Often these internal conflicts are a mixture of resource capture and political leadership twists. Did the archival material allow for recognition of the latter type of conflicts and were these subsequently left out of the equation as being not resource linked? ${ }^{9}$

\footnotetext{
${ }^{9}$ Conflicts, even if they start as 'genuine' resource conflicts might develop a political angle in the course of the conflict when leaders misuse the opportunity to settle scores for a variety of reasons, including political ones. The August/September 2012 upheaval in the Tana delta in
} 
Other explanatory factors that will impact on the rise or decrease of violent conflicts besides the amount of rainfall or availability of other resources, should, for the whole period under review, also be addressed:

1 The availability of institutions, rule of law, conflict mitigation, and police or military forces with relation to stock thefts.

2 Loss of livestock due to diseases.

3 Eagerness to diversify the herd composition (e.g. Turkana eyeing camels to replace cattle).

4 Cultural reasons: young men going for cattle raids to be able to pay a bride price (and changes in the amount needed to pay - South Sudan experienced conflicts recently after becoming independent and young men now eager to settle and build a family).

5 Availability of other weapons to fight (small arms, including AK 47s) as opposed to less harmful spears. Imbalances between fighting groups may especially have resulted in violent outcomes.

6 Increased numbers of youngsters partaking in schooling may have diminished the numbers of warriors and as a result the casualties.

All of the variables above, and likely other more specific reasons, impact upon the occurrence and level of conflicts and incidents. At the very least, the suggestion that abundance of water and grass means more conflicts is blurring the more common reason for raids: lack of cattle and restocking necessity. Land and water, both of which are non-lootable resources, can only be won either by invading and gaining, de facto or de jure, control over these sources as described by Oba (2011). This kind of resource capture is mostly the result of naturally outnumbering other ethnic groups, pushing aside or assimilation strategies.

On top of the aforementioned factors, it needs to be recognised that most of northern Kenyan pastoralists have increasingly reached structurally lower levels of wellbeing. This is among other factors caused by higher population numbers, certainly in comparison to the slowly increasing and fluctuating levels of livestock productivity (quantity and quality) over the last century. Northern Kenyan pastoralists are known to have seen their heads of livestock per person dwindle with peaks and troughs to structurally lower levels.

Finally, provisional results from on-going fieldwork in northern Kenya by the authors has shown that according to 118 Turkana pastoralists interviewed, conflict is most likely in the dry season $(53 \%)$ and not the wet season $(14 \%)$. However, a substantial number $(30 \%)$ indicated that conflicts occurred in both seasons. Although this does not means that the reason behind the conflict is the same throughout the year. Interestingly, $47 \%$ mentioned that in the dry season people co-operate as compared to $22 \%$ in the wet season, with $9 \%$ in both seasons.

Kenya that took the lives of some 110 people in a series of attacks was explained by a mixture of reasons ranging from herder/farmer planned wildlife conservation, land titling, (international) land acquisition and election politics. 


\subsection{POLITICS AND NATURAL RESOURCE CONFLICTS: THE EAPCC CONFLICT CASE}

In addition to the problematic interpretations of natural resource conflicts mentioned above, it is also worth illustrating the effects of potential intermingling of economic battles for political power and economic wealth on the struggle to claim natural resources. What may at first glance clearly appear to be a natural resource conflict may actually have much deeper and historic causes that need to be understood and exposed in order to be able to understand the real underlying factors.

A clear case in point is the conflict in Kenya concerning marble and gypsum. On 23 January 2012, a group of young Maasai stopped a lorry carrying marble in the small town of Isenya, Kajiado County. The driver of the Kenya Marble Company, a subsidiary of the East Africa Portland Cement Company (EAPCC), of which the main factory is located in the neighbouring Kamba dominated Machakos County some $30 \mathrm{~km}$ further to the north on the way to Nairobi, was told to unload his freight. The Maasai explained to the driver that his freight was mined some $60 \mathrm{~km}$ further south towards Namanga from the Mile 46 Quarry that belonged to the Maasai and should no longer be transferred to the factory for further treatment. The driver had no option but to drop the marble alongside the road. Other lorries experienced the same problem. Another Portland quarry in Kajiado (Kibini) saw its feeder road blocked so that no limestone could be brought to the Athi River Cement factory. Are we witnessing a natural resource conflict here or is something else at stake?

In the years preceding this conflict, the EAPCC was transformed from a parastatal into a private company, despite the Government maintaining a $27 \%$ stake. Since November 2010 and November 2008 a new managing director and chairman of the board of directors both from the Maasai community and affiliated to the PNU party of President Kibaki, had been in office, respectively. Since late 2011, their position was challenged by two Kamba ministers (Minister for Water and Irrigation and Assistant Minister for Youth Affairs) originating from the neighbouring Machakos County.

The motivation for the Kamba ministers' action is said to have been triggered by the upcoming implementation of a new administrative set up in Kenya that was itself brought about by the New Constitution (2010). Accordingly, power is to be devolved to the newly formed counties that will derive their benefits for a substantial part from revenues raised in each of these counties. Thus, for those counties that have mines, wildlife parks or a conglomerate of industries within their boundaries, the future looks bright. For less well-endowed counties, assistance will need to be sought from national levels. The Water Minister is said to have eyed control over the EAPCC as it is claimed to be operating within the Machakos County boundaries. The Kamba, however, had no control over the company's management whatsoever. Accusations of misuse of funds and other malpractices against the Maasai management had initially resulted in them being sacked. A court later ruled to reinstate the two Maasai officials. At the work floor tension was also building between the Maasai and Kamba employees. Cars belonging to the Maasai were damaged by Kamba workers, and Maasai employees in responsible positions were blocked from accessing the work premise by the Kamba workers.

Instigated by their leaders, the wider Maasai community grouped together to discuss how they should react to the situation. It was concluded that, first, the Maasai officials should be re-instated; second, the damage to the cars should be paid for; 


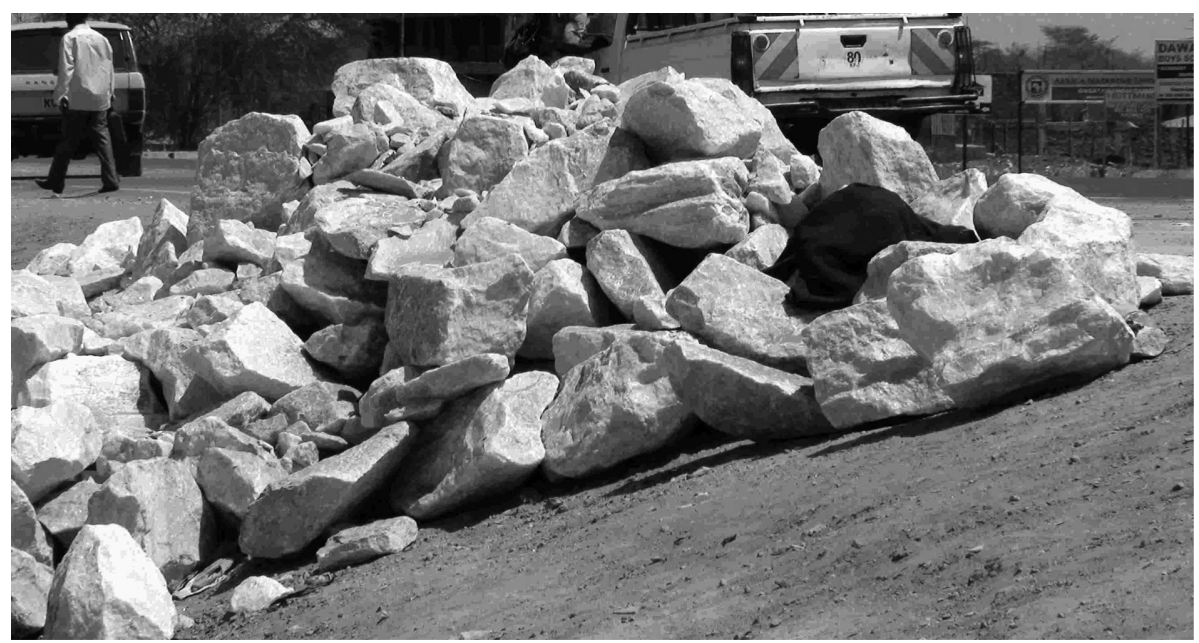

Figure 4.I Natural resource conflict: marble offloaded by the local community (@ M. Rutten).

and third, the original boundary separating the two counties should be re-established. This last condition was surprising, but ultimately the result of the Maasai digging into the archival records. In doing so, they learned that the original boundary between the Maasai and Kamba in the Athi region was secretly tampered with around 1965 without their prior knowledge. The Maasai claim that the then Kamba spokesmen, Paul Ngei, had approached President Jomo Kenyatta and requested the boundary be altered so that the factory of EAPCC would be on Kamba territory. He had reasoned that these Maasai have a wealth in wildlife (Amboseli National Park and Maasai Mara National Reserve), and minerals (Magadi Soda, Kenya Marble and Kibini limestone) among others, while the Kamba had nothing of the sort. Apparently Kenyatta agreed, albeit at a cost. The Kamba should hand over the area of Oldonyo Sabuk to Central Province, the province from which the President hailed.

The Maasai youngsters insisted that if their demands were not met, the Kamba could keep the factory building, but then seek raw materials themselves elsewhere; Kajiado County would no longer provide them. On January 9th the court ruled that the two Maasai officials should be re-instated. However, on February 10th, President Kibaki fired one of them once again and replaced him with another Maasai. Five days later, the High Court made it clear that this was an illegal move as the government was no longer a majority shareholder. The EAPCC conflict is a clear example of how politics, expectations of wealth and natural resources intermingle and feed into the different positions stakeholders take in a conflict of this nature.

\subsection{THE NATURAL RESOURCES - CONFLICTS FRAMEWORK}

The above deliberations will have clarified that there is a serious need to construct a framework that will assist in the disentangling of the various elements and drivers in 
the conflict-natural resources nexus. To start, there is a need to put aside the above confusion concerning natural resources and instead follow a more function-oriented categorisation of natural resources.

Figure 4.2 presents an analytical scheme that has been adapted from another model developed by Slootweg and Mollinga (2010) in the context of the Millennium Environmental Assessment that aimed at conceptual clarity for ecosystem services. Slootweg and Mollinga (2010) aim to clarify linkages and interactions between three subsystems, namely the biophysical, societal and resource management subsystems. Their model was considered to be a firm base for the model presented here, one that aims to bring conceptual clarity in natural resources and conflicts. To this end, we have added relevant information, such as the variety in natural resources, stakeholders and three key geographical levels (local to global) where resources are managed. Additionally, Peter Veit's listing of the four main power relationships in the field of resource allocation has also been added (see Chaudry and Lynch 2002).

It is worth noting further that the Slootweg and Mollinga (2010) model is the outcome of a range of improvements made to earlier models that increasingly grasped new thinking on how best to model the relationship between human beings and the (natural) environment. It has moved from a simple listing of functions of nature to a framework that differentiates the provision of goods and services - provisioning services (such as food and water), regulating services (such as regulation of floods, drought, land degradation, and disease), cultural services (such as recreational, spiritual and other nonmaterial benefits), and supporting services to maintain the other services (such as soil formation and nutrient cycling). It also recognises carrying services, which refer to the fact that a certain amount of space and substrate is needed for all living organisms in accordance with their particular environmental requirements.

In addition, supportive services are necessary for the production of all other ecosystem services. They differ from other services in that impacts on people are indirect and slow. "For example, soil formation processes usually play on a time scale that humans cannot oversee, and yet they are closely linked to the provision service of food production. Biodiversity is said to provide an 'insurance' service as the very diversity itself insures ecosystems against declines in their functioning" (Slootweg and Mollinga 2010).

In short, the service providing ecosystems are essential for human well-being. Functions will differ in accordance with region-specific and personal factors of the stakeholders grouped in the societal subsystem. These specific characteristics will determine the values stakeholders (including future demands) attach to the environmental services. Three broad groups of values are differentiated: social values, financial and economic values, and ecological values. Social values refer to the quality of life in its broadest sense and include food, safety, health and others. A specific social value is the claim for ecosystem services based on human rights values (e.g., water as a human right). Financial and economic values are related to both direct consumption (e.g. timber) and the inputs to the production of other goods and services (e.g. water for irrigation). Ecological values refer to the value that society places on or derives from the maintenance of the earth's life support systems (e.g., biodiversity for future generations; and ecosystems (e.g. mangroves serving as breeding grounds for fish supporting and economic activity elsewhere (fisheries)). 


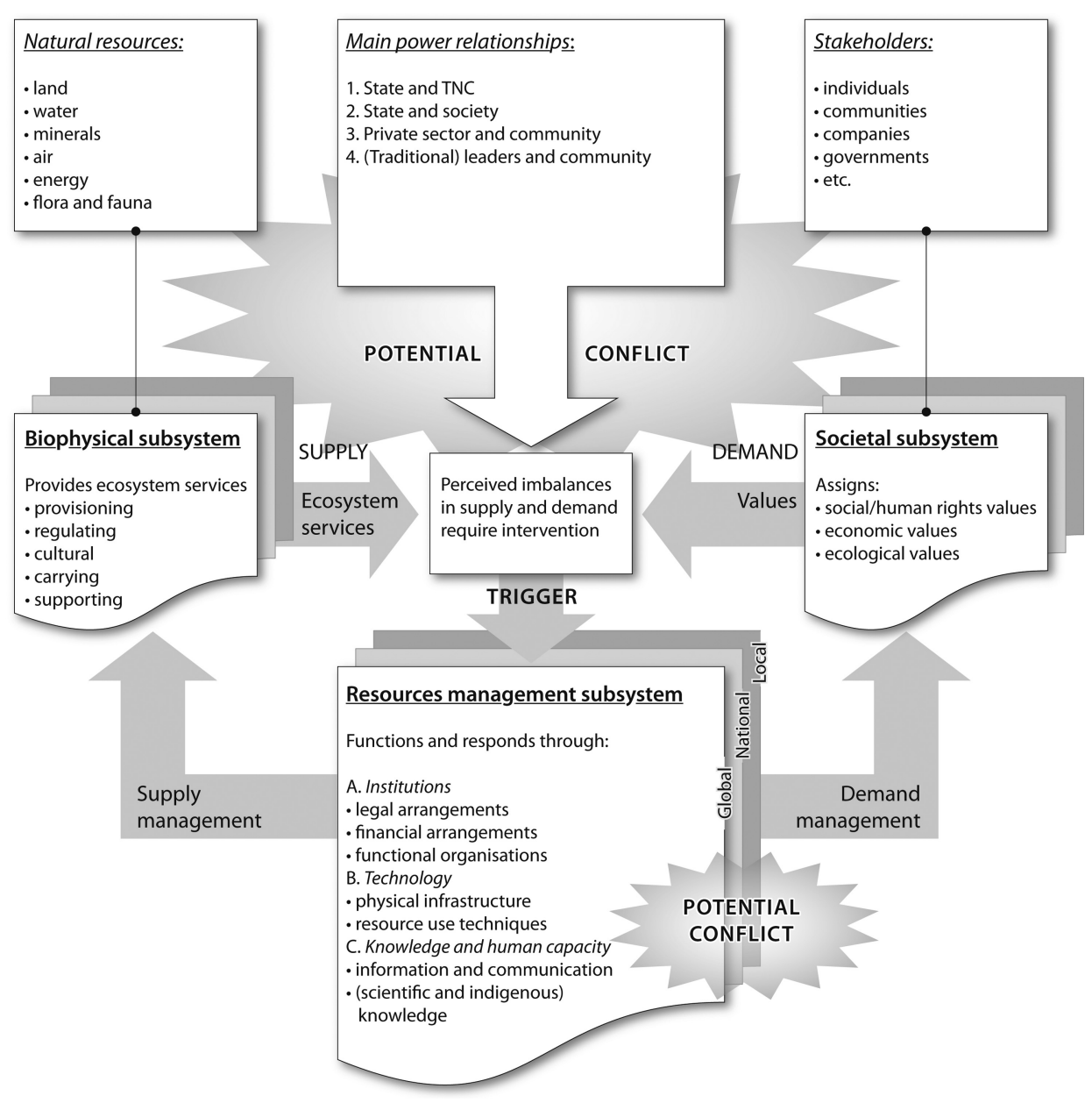

Figure 4.2 Conceptual Framework Natural Resources-Conflicts Nexus.

In most cases a single ecosystem service will support different stakeholders. Consequently, different and even opposing values can be attached. Even within a single stakeholder, e.g., the government, one might come across varying or even opposing views concerning the value of a natural resource. For example, a Ministry of Agriculture might differ in opinion towards the best (economic) use of a fertile, well-watered, area with the Ministries of Wildlife, Tourism or Livestock.

The information gathered for the EAPCC conflict case is used to fill the relevant cells of the conceptual framework (Figure 4.3). It helps us list the key stakeholders and resources that play an active role in the conflict. It underlines, for example, the need to differentiate between various authoritative (sub)sections within the country: president, judges, administrators, politicians, and local leaders. Interestingly the EAPCC case shows power struggles, including signs of a mature democracy when the High Court 


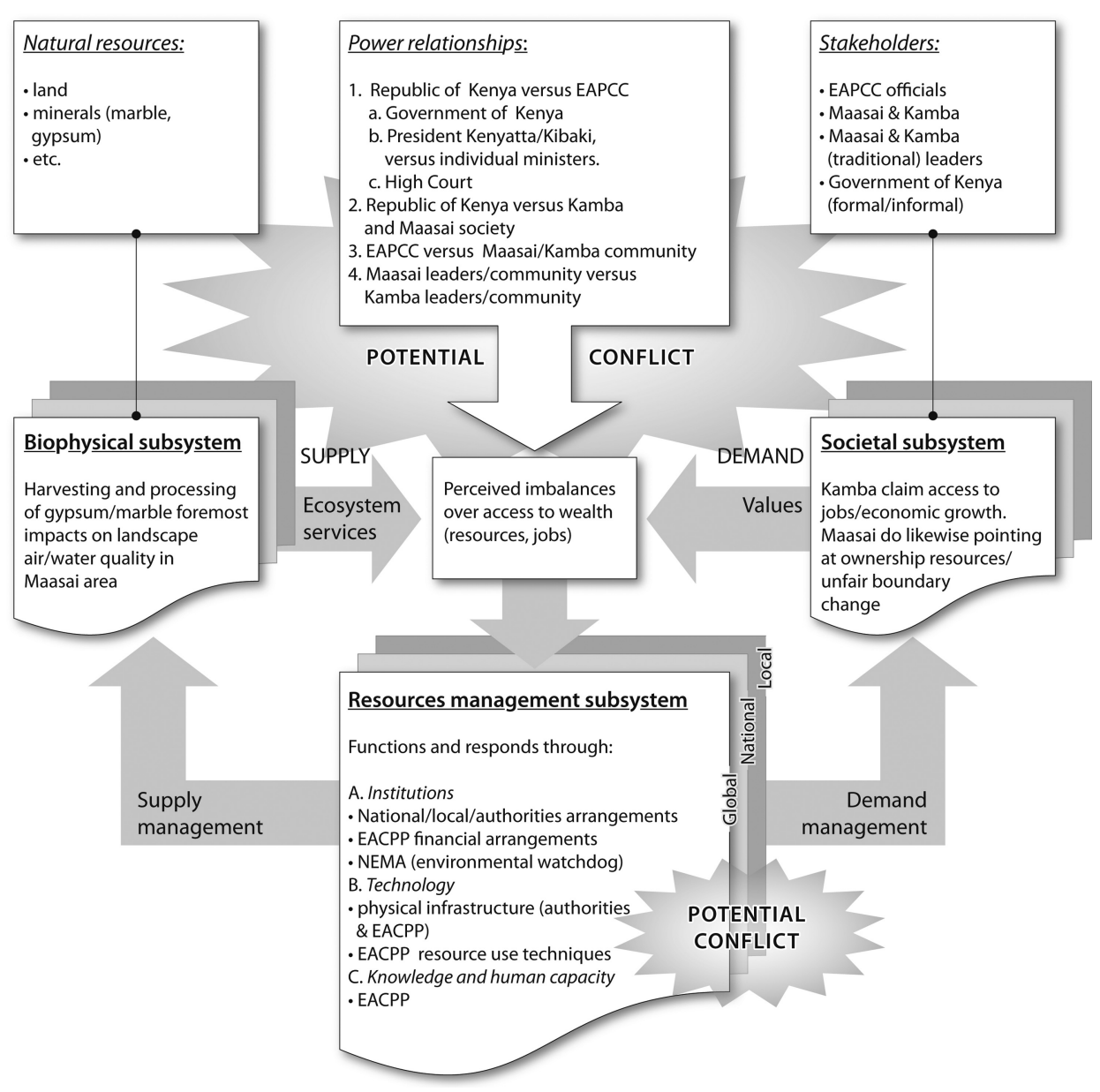

Figure 4.3 Framework Marble/Gypsum - Conflicts In southern Kenya (Kamba and Maasai).

ruled against a President Kibaki's decree to interfere in the appointment of key officials. This option for justice was not available to the Maasai during the times of President Kenyatta when he apparently made a secret deal with a Kamba politician over a shift of a boundary, adding land to the Kamba territory without the Maasai knowing.

This historical dimension is as important as the recognition of which natural resources are at stake, where these resources are located and or mined (which is the geographical dimension), and whether other elements (jobs created through these resources) play a role. Potential environmental problems, such as dangerous quarry pits, air pollution, destruction of topsoils, and noise from blasts, among others, can be identified. However, these are not the key issues at stake. The economic value of the social subsystem is central in this conflict over natural resources. The scheme also helps us to establish the geographical scale of the conflict, which in this case was situated at local/regional and national levels. Finally, having disentangled all these players and 
actions the model helps to pinpoint where counteractions are needed to resolve the situation and overcome tensions.

Within the context of the CoCooN Initiative Kenya programme, fieldwork will be conducted in four river basins in Kenya. Empirical studies in these regions aim to contribute to a testing of the framework. In addition, three central hypotheses will serve as a guideline for these studies:

1 Increased diversification of household economies leads to intensified occurrence of conflicts;

2 Sudden changes in resource availability cause conflicts;

3 The absence of (effective) institutions allows for more conflicts over natural resources.

These hypotheses will be tested by studying a wide variety of natural resource users, including pastoralists, small-scale farmers, fishermen, large scale foreign and local commercial agriculturalists, foreign NGOs involved in housing projects, eco-tourism entrepreneurs, and government-driven Water User Associations. Attention to reconciliation efforts through both traditional and government instigated Peace Committees is also part of the research plan. Finally, the political dimension will be given special attention to better understand at which moment of an evolving conflict this element is of crucial importance either to fuel or stop the process.

\subsection{CONCLUSION}

Understanding natural resources and conflicts requires a thorough analysis of the biophysical and societal subsystems, a clear definition of the type of natural resource and the various ecosystem services provided, the values attached by several stakeholders, the management system put in place at several geographical levels, and the key power relationships that are at stake in the resource allocation arena. Finally, a historical analysis review will add to a thorough understanding of the causes and effects of conflicts over natural resources. The variety of disciplines involved in the study of struggles over natural resources has contributed to conceptual confusion. Based on the certified framework that presents the linkages between ecosystem services and society, we have added geographic dimensions of management, acknowledging the globalised dimension of institutions, technology and knowledge, and key power relations.

\section{REFERENCES}

Barrow C. 1999. Environmental Management: Principles and Practice. Routledge Environmental Management Series.

Bob, U. and S. Bronkhorst. 2010. Environmental Conflicts: Key Issues and Management Implications. African Journal on Conflict Resolution 10, no. 2: 9-31.

Brown, I. 2011. The Paradox of Plenty: The Political and Developmental Implications of Natural Resources in Sub-Saharan Africa. Africa Portal, Backgrounder no.10 (September 2011). 
Chaudry, S. and O. Lynch (eds). 2002. Amplifying Local Voices, Striving For Environmental Justice - Proceedings of the African Public Interest Law and Community-Based Property Rights Workshop, Arusha, Tanzania, 1-4 August, 2000.

Derman, B., R. Odgaard, and E. Sjaastad (eds). 2007. Conflicts Over Land \& Water in Africa. Oxford: James Currey.

Dietz, A. J. 1996. Entitlements to Natural Resources - Contours of Political Environmental Geography. Utrecht: International Books.

Frerks, G. 2007. Linking Environment and Conflict, Building Blocks for a Knowledge Innovation and Research Strategy. The Hague/Wageningen: Wageningen University, BUZA, NWO.

Homer-Dixon, T. 1999. Environment, Scarcity, and Violence. New Jersey: Princeton University Press.

Kagwanja, P. 2003. Globalizing Ethnicity, Localizing Citizenship: Globalization, Identity Politics and Violence in Kenya's Tana River Region. Africa Development XXVIII, no. 1 and 2: 112-152.

Kok, A., W. Lotze and S. Van Jaarsveld. 2006. Natural Resources, the Environment and Conflict. Durban, South Africa: African Centre for Constructive Resolution of Disputes (ACCORD).

Lederach, J. P. 2005. The Moral Imagination: The Art and Soul of building. New York: Oxford University Press.

Martin, P. 2007. Conflict and its Socio-Economic Impact in Garsen Division, Tana-River District. Master diss., Moi University.

Mazor, J. 2009. A Liberal Theory of Natural Resource Property Rights. PhD diss., Harvard University.

Mehta, L., M. Leach, P. Newell, I. Scoones, K. Sivaramakrishnan, and S. A. Way. 1999. Exploring Understandings of Institutions and Uncertainty: New Directions in Natural Resource Management. IDS Discussion Paper 372, Sussex.

Montani, G. 1987. Scarcity. In The New Palgrave: A Dictionary of Economics, ed. J. Eatweel, R. Palgrave, M. Milgate, and P. Newman. London: MacMillan.

NRC. 2010. The Natural Resource Charter, November 2010, www.natural resourcecharter.org.

Oba, G. 2011. Colonial Resource Capture: Triggers of Ethnic Conflicts in the Northern Frontier District of Kenya, 1903-1930s. Journal of Eastern African Studies 5, no. 3: 505-534.

Obi, C. 1997. Economic Adjustment and the Deepening of Environmental Conflict in Africa. Paper for The Nordic Africa Institute.

Oxford Dictionary. 2013a. http://oxforddictionaries.com/definition/english/natural\%2B resources.

Oxford Dictionary. 2013b. http://oxforddictionaries.com/definition/english/conflict?q=conflict.

Peil, M. and O. Oyeneye. 1998. Consensus, Conflict, and Change: A Sociological Introduction to African Societies. Nairobi: East African Educational Publishers.

Perelman, M. 1975. Natural Resources and Agriculture under Capitalism: Marx's Economic Model. American Journal of Agricultural Economics 57,4:701-04.

Robbins, S. nd. "Conflict management" and "Conflict Resolution" are Not Synonymous Terms. http://www.realmarcom.com/documents/conflict/robbins_conflict.pdf

Rutten, M. 2008. Why De Soto's Ideas Might Triumph Everywhere But in Kenya: A Review of Land-Tenure Policies Among Maasai Pastoralists. In Inside Poverty and Development in Africa: Critical Reflections on Pro-Poor Policies, ed. M. Rutten, A. Leliveld and D. Foeken. 83-119, Leiden: Brill.

Rutten, M. 2010. Key Turning Points in Kenya's History of Land Governance: A Synoptic Historical and Geographical Tour in Seeking answers to the Country's Biggest Question. Draft paper for RUZIVO/ASC workshop November 2010, Harare.

Said, M., I. Naini, and C. Douglis. 2009. Sustaining Communities, Livestock and Wildlife: A Guide to Participatory Land-Use Planning. Rome: FAO. 
Slootweg, R. and P. Mollinga. 2010. The Impact Assessment Framework. In Biodiversity in Environmental Assessment Enhancing Ecosystem Services for Human Well-Being, ed. R. Slootweg, A. Rajvanshi, V. Mathur, and A. Kolhoff, 87-125, Cambridge: Cambridge University Press.

USAID. 2002. Nature, Wealth, and Power - Emerging Best Practice for Revitalizing Rural Africa. Discussion paper prepared by USAID Environment \& Natural Resources Team of the Sustainable Development Office in collaboration with CIFOR, Winrock, IRG, WRI, Washington DC.

Waller R. 1976. The Maasai and the British 1895-1905 the Origins of an Alliance. The Journal of African History 17:529-53.

Wikipedia. 2013. Natural Resource. http://en.wikipedia.org/wiki/Natural_resource\#cite_note-5

Witsenburg, K. and A. W. Roba. 2007. The Use and Management of Water Sources in Kenya's Drylands: Is There a Link Between Scarcity and Violence Conflicts. In Conflicts over land \& water in Africa, ed. B. Derman, R. Odgaard, and E. Sjaastad, 215-38, Oxford: James Currey. World Resources Institute. 2005. The Wealth of the Poor: Managing Ecosystems to Fight Poverty. Washington DC: WRI. 


\title{
Analysing the role of politics in groundwater management - research in Ethiopia, Palestine and Yemen
}

\author{
Ebel Smidt ${ }^{1}$,Taye Alemayehu' ${ }^{2}$,Adel Al Weshali ${ }^{3}$, Karen Assaf ${ }^{4}$, \\ Abdullah Babaqi ${ }^{5}$, D. Abdel Ghafour ${ }^{6}$, Rozemarijn ter Horst ${ }^{7}$, \\ Frank van Steenbergen ${ }^{8}$, Kifle Woldearegay ${ }^{9}$ \& Omar Zayed ${ }^{10}$
}

\begin{abstract}
Ethiopia, Yemen and Palestine are two countries and a nascent state that face different challenges concerning access to groundwater. Common problems range from groundwater depletion caused by excessive pumping, a lack of information on groundwater resources, and obstruction of access and the denial of water rights by other parties. These challenges may appear unrelated at first glance, but they are in fact linked by the importance of the political arena in removing barriers and furthering development. This chapter presents the Groundwater in the Political Domain research project and analyses the functioning of the 'political black box' with regard to groundwater governance in these three country settings. The authors argue that the role of politics is crucial, but differs also because of the nature of the state. Palestine and Yemen can best be characterised as fragile states, while Ethiopia is a democratic state in development with elements of an autocratic state. An enabling environment, triggered by progress in politics, institutions, or the socio-economic domain, is suggested to help actors develop themselves and the resource. Another lesson from the analysis is to allow the narrative of the cases to take into account the interaction between the resource, the different users and the researchers.
\end{abstract}

Keywords Groundwater, politics, black box, governance, conflict, cooperation, institutions, entropy, Ethiopia, Palestine, Yemen.

\footnotetext{
${ }^{1}$ Corresponding author

PhD Researcher at Delft University of Technology, Netherlands (Corresponding author: smidt.sg@inter.nl.net).

${ }^{2} \mathrm{PhD}$ Candidate at Ethiopian Institute of Water Resources, Addis Ababa University, Ethiopia.

${ }^{3}$ Associate Professor at the Faculty of Agriculture, Sana'a University, Yemen.

${ }^{4}$ Arab Scientific Institute for Research and Transfer of Technology of Palestine.

${ }^{5}$ Professor of Chemistry and Director of the Water and Environment Center at Sana'a University, Yemen.

${ }^{6}$ Principal Hydrogeologist and Water Resources Expert at Palestinian Water Authority.

${ }^{7}$ Consultant at Ter H2orst: Water Projects.

${ }^{8}$ Consultant at MetaMeta.

${ }^{9}$ Department of Earth Sciences, Mekelle University, Ethiopia.

${ }^{10}$ Principal Geologist, Hydrogeologist and Water Resources Expert at Palestinian Water Authority.
} 


\section{I INTRODUCTION}

Ethiopia, Yemen and Palestine are two countries and a nascent state that face different challenges concerning access to groundwater. Common problems range from groundwater depletion caused by excessive pumping, a lack of information on groundwater resources, and obstruction of access and the denial of water rights by other parties. These challenges may appear unrelated at first glance, but they are in fact linked by the importance of the political arena in removing barriers and furthering development.

The Groundwater in the Political Domain project (GP-Project or GPP) that is funded by the Netherlands CoCooN programme (see chapter 1, this volume) aims at learning lessons from the interaction between politics and groundwater governance and management. The project employs inductive methods of research; letting the specific field situations in the three countries provide their own context for data gathering analysis and action based research strategies. It is assumed that the combination of an inductive, fieldwork-based methodology and a reflective scan of existing theories will lead to new theoretical insights.

The challenge is to better understand the complexity surrounding groundwater use and management, and to identify opportunities to intervene in and engage with the political domain as has successfully been done in the technical, institutional and socio-economic domains over the last decades (van der Gun 2012; Wijnen et al. 2012; Smidt and Satijn 2013). Attention for local experience and knowledge has grown as well, and good governance and institution building have become a main focus of international policy (United Nations 2012). The political domain, however, remains largely ignored in contemporary groundwater management. Despite the fact that politics clearly plays a crucial role, it is still largely a black box. By highlighting the political domain, we hope to gain an understanding of this last piece of the groundwater puzzle. Despite it being a vital part of the context of groundwater management, barriers exist between the political domain and groundwater management (figure 5.1). Theoretically one might argue that politics belongs to the institutional domain (defined as the organizational field). However, for the sake of practical policy development, it makes more sense to separate the two. This holds true in large part because the political domain deals with decision making on policies and budgets of institutions. The technicalities of groundwater management are considered tools that can be used or not depending on the interaction between the political, socio-economic and institutional domains.

Of course, we do not intend to state that politics is everything. As one of the actors in the Palestinian water sector cautioned: 'Don't forget politics, but put it in the right perspective'. This chapter is motivated by the quest for these perspectives on the relation between groundwater management and the political domain.

The framework that is developed and will be discussed in this chapter consists of general theories of conflict and water management that are flexible enough to allow for "surprises" (unforeseen outcomes) and are specific enough to be applicable in the three quite different cases. This chapter will present our view on the concepts that are central to the discussions: groundwater as a resource (section 2), the relation between conflict, cooperation and the political black box (section 3), the field situation in the three countries (section 4), the role of politics and different type of states (sections 5 and 6), factors of change (section 7) and lessons learned thus far concerning possibilities for intervention and engagement, and its theoretical framing (section 8). 


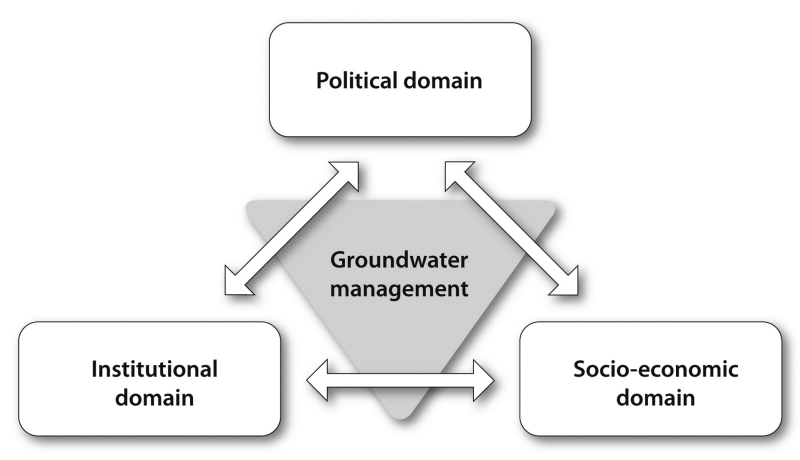

Figure 5.I The context of groundwater management.

\subsection{GROUNDWATER AND MANAGEMENT OF COMMONS}

Groundwater is an archetypal example of a commons. It is accessible by many and the knowledge of the resource is often limited. At present, an estimated $70 \%$ of the world's population depends on groundwater for its basic water services. In $51 \%$ of countries, groundwater withdrawal tops $100 \mathrm{~m}^{3}$ per capita annually. Groundwater has created the fragile miracles of accelerated agricultural production in important rural economies in South Asia, China, North Africa and the Middle East. In large irrigation systems in South Asia and North Africa, 30-50\% of the water used by farms comes from groundwater, creating so-called conjunctive management systems. Other than surface water development, much of the groundwater development is done by private, individual initiatives. In several areas, groundwater is also the resource that still provides the means to overcome drought or climate change, particularly if groundwater development is combined with the recharge and retention of rainwater, run-off and flood water. Despite all of these achievements, there are numerous groundwater disasters - areas with lowered groundwater tables, unbalanced economic and ecological systems, and groundwater quality getting out of hand due to intrusion, upconing or pollution (Wijnen et al. 2012).

Both the promise and the problems have garnered attention for managed groundwater development. Yet, by and large, effective groundwater management is not common in spite of the interests at stake. Groundwater management makes appearances on the political agenda as a captive resource (the greening of) or an area of concern (water security) and competition (race to the bottom). The development of groundwater has created institutional responses (van der Gun 2012). However, effective real-world management of groundwater through regulating usage, protection of quality or systematic replenishment of the water buffer is rare, especially in low-income countries (Wijnen et al. 2012).

Groundwater as a resource is unique in a number of aspects:

- Groundwater is more widespread than surface water and the largest non-frozen source of fresh water.

- Physical boundaries of groundwater reserves generally do not match with administrative boundaries. 
- It is invisible - there is always an information problem between users; who is using what and how much is left?

- Depending on the local hydrogeology, extraction by one user will often affect groundwater availability for other users.

- Depending on the depth of the water bearing strata, groundwater can be accessed individually or in relatively small groups.

- It is most commonly perceived by the users as 'local' - which contributes to a tendency of local water managers to elude central regulation or control and therefore stimulates local autonomy in management and governance while the effects of the local management might not be in agreement with regional or national objectives.

- The locality of the resource makes it difficult to create awareness of the effects of groundwater use on other users of the same reservoir.

- Groundwater can be replenished through natural and manmade recharge, making it a renewable resource in principle.

Hardin (1968) introduced the idea of the tragedy of the commons, focusing on how the commons will suffer from overuse by individual users in the absence of property rights. It is interesting to note that later research on the management of the "commons" has provided more insight into the mechanisms that cause the tragedy and, more importantly, mechanisms that can prevent it (Ostrom 1999; Ostrom et al. 1999; Dietz et al. 2003). Properly stimulating and rewarding co-operators and frustrating and penalising free-riders can create enough internal authority to compensate for the intrinsic weakness of external authorities (Vollan and Ostrom 2010). A closer analysis of these external authorities is still needed as it provides more understanding of the underlying causes of conflict and provides opportunities to generate alternative solutions. The role of politics is very important in this respect as this domain has the power to either obstruct or facilitate the development of the resource.

In general, it might be helpful to compare nature with a factory that uses renewable and depletable natural assets (Collier 2010; Low 2010), and include the interaction between the human system and ecosystems by analysing the ecosystem services (Costanza et al. 1997). Groundwater can be both types of assets, renewable or nonrenewable. If groundwater management fails, the resource can turn into lost assets. The use of groundwater is expected to increase and therefore the challenge of safeguarding a good balance between the role of groundwater in the short and long term interest of the human system and the ecosystem becomes larger. The resource is valuable in classical economic terms as well, in large part because we let our access to and dependency on the resource be determined by the market. If the dependency dwindles, the cost lowers. In the case of water, however, it is more likely that we become more dependent on it as our economies develop. This is due to the fact that economies need water to thrive, especially emerging economies, and good water will become scarce as dependency, use and pollution increase. Moreover, societies become more dependent on water when water and other governance regimes, which are resilience factors that aim at proper management of commons, are weak or even absent.

A governance regime is the set of implicit or explicit principles, norms, rules and decision-making procedures around which actors' expectations converge (Krasner 1983). Governance regimes can differ greatly, reflecting the resource differences in quality, quantity and the number of actors and governance levels involved. The sets of 
principles, norms and rules are formed within several of the regime's arenas. Actors in the governance regime meet within these arenas and create the principles and norms. This happens at every governance level (from the international to the individual level) and the activities on these levels are linked. An example at the international level is the formation of the Convention on the Law of the Non-Navigational Uses of International Watercourses and the formulation of the Draft Articles of the Law on Transboundary Aquifers, which aims at setting up rules for a governance regime in which fair and equitable use and the principle of no significant harm are paramount (United Nations 1997; Smidt and Satijn, 2013). This example further shows how difficult it can be to establish a working regime with many different actors. Moreover, the regimes are influenced heavily by the political, socio-economic and institutional domain within which they are placed. Water governance takes place on different levels in a society, and in different spaces of governance. Feitelson and Fischendler (2009) recognise five different spaces of governance: the household, community, national, basin and economic level. These different spaces of governance form different arenas in which actors face one another. These spaces are interlinked and often defined by political structures.

\subsection{CONFLICT AND COOPERATION}

When we discuss conflict over resources, it is important to keep an eye on the complete picture. Resources are part of the natural environment, and the human environment is contingent on both. Influence and feedback mechanisms ensure that both the human and natural system have a large impact on each other (Costanza et al. 1997). The differences in the importance of resources for the human system and their importance in the ecosystem also have a large influence on conflict. While oil is most important in the human system and has little importance for sustaining the ecosystem, water is of paramount importance to sustaining both systems. However, most people are more aware of international and violent conflicts over oil than they are of conflicts over water (Smidt and Satijn 2013). The latter do not lead to international wars, but they do cause tensions, contribute to local conflicts, and result in considerable loss of life and goods on a local scale. ${ }^{11}$ This example demonstrates that resource management conflicts differ greatly, whether the conflict is competitive, manipulative or inspired by factors unrelated to the resource itself. This makes a broad theory of resource conflicts an impossible feat. It is nevertheless useful to view the mechanisms at work and recognize them, especially with regard to the political domain. Optimisation of cooperation is the primary focus of literature on transboundary water management, common pool resources management, and international and inter-organisational relations. Cooperation generally means working together. In practice, it may refer to the

\footnotetext{
${ }^{11}$ Price and monopolised access to resources are key factors that determine the risk of war for a resource. There is currently an international discussion about the possibility of 'water wars'. By facilitating the development of cheap desalinisation techniques and higher energy efficiency in transportation of water, the risk of international conflicts for water will be minimised. Uncertainty arises when water is part of a conflict that is rooted in the domains of politics and religion. The GPP's contribution to this dispute will be to link knowledge available within the water sector (Wolf et al. 2005; Zeitoun et al. 2010) to other sectors like public health (viz. de Jong, 2010) and as called upon in integrative studies (Steenbergen and El Haouri 2011; Smidt and Satijn 2013).
} 
exchange of data and information ("technical cooperation"); to the conclusion of formal agreements (whether the agreement is implemented and solves any problems or not); to cooperation on minor issues; and to cooperation in addressing the root causes of problems (Zeitoun et al. 2010).

Conflict may refer to a difference in views, (perceived) interests and underlying values between two or more actors (substantive conflict). However, it may also refer to a problematic relation between actors (relational conflict). This may range from slight feelings of unease and tension, to a total stop of communication and even acts of violence (Zeitoun and Mirumachi 2010). The two types of conflicts do not necessarily go hand-in-hand. Decreasing per capita water availability is likely to increase competition over scarce water resources and hence substantive conflicts, but it will only lead to relational conflicts if the current relations are not strong enough to handle these differences.

Conflict is often seen as the opposite of cooperation: more conflict means less cooperation and vice versa. The relationship between conflict and cooperation is, however, probably more complex than a simple opposite position would suggest. In practice, the prevalence or absence of both conflict and cooperation exist on a vast continuum. For example, cooperation on minor issues may take place, while concomitantly root problems are not addressed and underlying conflicts remain. In situations of power imbalance, the stronger party could adopt this strategy in order to depoliticise the situation, appease the weaker party, maintain the status quo, and perpetuate inequality. The weaker party may adopt this strategy for pragmatic reasons, because they are not strong enough to affect any fundamental change, but any agreement reached will be insufficient and unstable (Zeitoun et al. 2010).

It is also important to avoid seeing cooperation as an 'ideal state'. There are many forms of cooperation that perpetuate inequality or resource degradation. Similarly, conflict is not necessarily unproductive or counterproductive; it can take many shapes and even facilitate a transition to a situation of resource management that is better balanced. There are situations in which conflict and cooperation exist more or less in parallel, creating interdependencies, structural changes and new dynamics provides room for new explanations and policy improvements.

Focusing on conflict and cooperation alone might close our eyes to options where neither conflict nor cooperation exists. Accepting this as a benign situation per definition would be naïve. The case of no cooperation and no conflict is fine as long as there are no underlying problems. However, in groundwater management, as in most governance systems, there often are underlying problems. We call the situation where no action is undertaken despite underlying problems a void. Voids do not automatically have a positive or negative effect, but they can be signals of a tacit suppression of conflict by a strong party that benefits from inaction, or signals of a general lack of institutional capacity and social capital. Addressing this situation and uncovering its background is therefore preferable.

In addition to the discussion of these mechanisms, we would like to add the following four considerations to the existing theoretical perspective: (1) how are these different conflicts and examples of cooperation affected by the larger political context; (2) how can these examples add to knowledge of this political context, often considered a black box; (3) how are voids left to persist or solved - especially when they are reflecting larger problems; and (4) how can we further contribute to the mutual interdependency of cooperation and conflict. Recalling that groundwater issues are locally 
grounded, the discussion here is essentially one of local versus more central levels. In our case studies, the dilemma between centralisation and decentralisation is obvious. In Yemen, for example, the lack of central governance leads to local catastrophes. In the Palestinian case, the bigger picture is tilted and only some small incidental local successes are allowed or possible, consequently giving rise to the question of creating a critical mass of local cases. Finally, in Ethiopia local basic operational problems stand in the way of proper groundwater management.

\subsection{CASE STUDIES: GROUNDWATER MANAGEMENT IN ETHIOPIA, PALESTINE AND YEMEN}

The project's work is focused in three different countries: Ethiopia, Palestine and Yemen. At first glance, the cases are seemingly unrelated. However, as we delve deeper, we can see many similarities or learning possibilities. The groundwater issues in all three countries will be laid down in this section. References to visual impressions are given in Box 5.1 .

\section{Box 5.1:Visualising the experiences}

Stories and analysis form an image of the challenges people in Yemen, Ethiopia and the Palestine face. Video material provides additional opportunities for communicating the reality in these areas. The GPP-consortium has noticed the importance of sharing experiences from the field. We cannot take the reader physically to Yemen, Ethiopia and Palestine, but impressions can be found at (all sites accessed September 10, 2013):

\section{General GPP-videos}

http://www.thewaterchannel.tv/en/videos/categories/viewvideo/599/groundwater/ groundwater-in-the-political-domain

http://www.thewaterchannel.tv/en/videos/categories/viewvideo/577/groundwater/ groundwater-in-the-political-domain

\section{For Ethiopia:}

http://www.thewaterchannel.tv/en/videos/categories/viewvideo/1320/groundwater/ groundwater-in-ethiopia

\section{For Palestine:}

http://www.thewaterchannel.tv/en/videos/categories/viewvideo/1514/

transboundary-water-management/cocoon-water-in-qalqiliya-palestine

For Yemen:

http://www.thewaterchannel.tv/en/videos/categories/viewvideo/1375/groundwater/ disappearing-groundwater-and-desertification-in-coastal-yemen http://www.thewaterchannel.tv/en/videos/categories/viewvideo/1330/ecosystem/ cocoon-projects-research-activities-in-yemen 


\section{Ethiopia}

In Ethiopia, poverty is combined with plenty. Inequitable distribution of resources stretches right down to the accessibility of water resources throughout the country. Although the government plans to do more, water resource development, especially groundwater development, is modest at best in Ethiopia. Initial estimates of the availability of groundwater have been low - the official figure stands at $2.6 \mathrm{BCM}^{12}$ of available groundwater. However, such figures are now generally accepted as inaccurate, representing a mere fraction of the resource that is actually available.

In the last three years, expectations of the scope for groundwater development have risen steeply. Increasingly groundwater is politically 'discovered' as a full complement to the development of surface water. The 'discovery' of the groundwater resource enables the country to unlock the agricultural potential of areas far away from main rivers, including the Abbay / Blue Nile. In an area that often depends on food aid, this development is of incredible importance. Taken together, the current manifestations of various plans are very ambitious. Uncertainty remains with respect to the resource and the availability of some of the assumed resources still needs to be established.

The Ethiopian component of the research focuses on the Raya-Kobo valley, an area with high groundwater potential within the Baro-Akobo basin, but also the scene of the horrific 1984 famine. Research is on-going on poverty alleviation approaches through safety net programs and economic growth through small-scale irrigation. In the Raya-Kobo valley, the groundwater resource is now partly developed, and the government plans to do more. Many of the constructed wells were not operational for about 3 years, while some of the newly government-constructed wells are often damaged by villagers. The project team had no idea why the villagers targeted these wells. Investigations revealed that suspicions that private investors would use the wells played a key role. In Ethiopia, people do not own their farmland. Instead, it belongs to the state. In the region where the wells were being damaged, the government's plans were not made clear to the communities in the study areas and this created fear and anger among the population. Another development in groundwater irrigation in the Raya-Kobo valleys is the emergence of young and more educated entrepreneurs, aptly named "change agents," who are involved in small-scale irrigation by leasing land from farmers (Kumsa 2011).

Among the twelve basins in Ethiopia, Baro-Akobo basin covers only $6.9 \%$ of the total area $\left(76,102 \mathrm{~km}^{2}\right)$. It does, however, contain the second largest area irrigable land $(734,500 \mathrm{ha})$, the second highest hydropower potential $\left(48.1 \times 10^{9} \mathrm{kwh} / \mathrm{yr}\right)$, and has the third highest amount of runoff $\left(11.81 \times 10^{9} \mathrm{~m}^{3}\right)$ (Selkhozpromexport 1990; Tams 1997). Despite its small size, it has very prominent and unique hydrological characteristics. This basin is home to one of the few remaining high rainforests between 2000 and $3500 \mathrm{~m}$ altitude and more than 40 species of mammal wildlife (ETV Documentary, March 2012). Moreover, the basin's trans-boundary nature and its importance to South Sudan and other downstream countries give the basin considerable geopolitical importance. This research is therefore aimed at addressing current and future water development challenges by conducting applied groundwater hydrological research in

\footnotetext{
${ }^{12}$ BCM: Billion Cubic Metres
} 
the Lower Baro-Akobo Basin where little is known about the functioning of the groundwater buffer in the predominant wetlands. This basin has been selected because of its high economic importance and its hydrological and economic dynamism.

Existing studies suggest that the Baro-Akobo basin is among the most vulnerable basins of Ethiopia. The lack of reliable hydrological and environmental monitoring data with high temporal and spatial resolutions are some of the major obstacles to designing development projects, observing possible changes in the hydrologic system and monitoring the environment to ensure sustainable use of the natural resources. Dissecting the black box of the interrelationship between technical, institutional and political issues is the first step in the Ethiopian leg of the project.

\section{Palestine}

Water use in Palestine depends almost exclusively on groundwater resources. The spectrum of problems for the water authorities, the public water supply and sanitation utilities, and the private sector ranges from a) a rapidly changing hydrological regime linked to riparian over-pumping, which could be associated with climatic change; b) a lack of technical and financial means to investigate the hydrological regime, and control and manage the water system; c) a lack of institutional and organizational capacity; and d) an unequal power balance concerning control over the transboundary water resources shared by Israel and Palestine, which has resulted in a lack of access to the resources for the Palestinians. As recently outlined by Amnesty International from a human water rights point of view (Amnesty International 2009), the latter factor is extremely dominant.

Most groundwater reservoirs under the West Bank are shared with Israel. Since the occupation in 1967, Israel has built a system of military orders to control the water resources and prevent the Palestinians from developing their water resources. Although the Oslo agreements of 1993 and 1995 inaugurated the Palestinian Water Authority and a Joint Water Committee, the changes in power distribution in groundwater management between Israel and the Palestinians are, at the very least, disputed by the Palestinians. Moreover, the creation of the Joint Water Committee has not prevented the systematic overuse and pollution of the groundwater resources. Procedures for drilling new wells through the Joint Water Committee are lengthy and the results have thus far been unpredictable. This holds true especially for the $83 \%$ of the land coverage of the West Bank that is under Israeli military rule. Due to the separation wall, gaining access to land and wells is practically impossible for many Palestinian farmers. Such endeavours have therefore only further contributed to a future vision for the region in which water supply will heavily depend on desalinized water with all of the political and economic implications (Assaf 2004; Galema 2012; Smidt et al. 2013).

Within the West Bank, the Palestinian Water Authority selected the Qalqiliya Governorate as a case study. In this governorate, groundwater is available, but often not accessible due to the wall that separates many villages from each other. The response studies performed in Palestine give insight into the adaptive power of the farmer's cooperatives in the Governorate of Qalqilya (Galema 2012). Farmers have lost large tracts of their lands due to the construction of the wall and surrounding Israeli settlements, but by introducing more intensive forms of agriculture they have managed to continue 
farming and sustain their livelihoods. Of course, their ultimate goal is to recover their lands. In practical terms, however, their largest concern is the improvement of the marketing position of their products and a decrease in their production costs. Both the Palestinian Authority and the international community can provide support. Currently, an action plan is being prepared for the second phase of the project.

Based on all of the above, one can see that Palestine does have water resources from a geological, geographical and hydrological point of view. However, Palestine cannot utilise these resources due to the current political situation, especially the extraction practices of the Israelis both within the West Bank and along the Israeli side of the West Bank's Green Line. Additionally, it is extremely important that the water resources that are being utilised in Palestine are protected from contamination. Since Palestinians have no access to the waters of the Jordan River Basin, the onus is on the groundwater resources that are being used and that need to be protected. The increasing consumptive use of water due to population growth and the extreme need for development results in the full use of existing resources and accentuates the pressing need for new sources and efficient use of the existing resources.

The Palestinians do, however, need to be observant. Increasing industrialisation and economic growth without pollution prevention inevitably leads to more hazardous waste generation. Economic utilisation of water and pollution control are basic tools to avoid irreversible deterioration of water sources that will impair the future development of existing and potential areas. Every cubic meter of water deemed unusable due to poor quality or improper utilisation is in reality a direct loss in the water supply for all Palestinian user sectors (Assaf 2004b).

Rational water management in Palestine should be founded upon a thorough understanding of all the types of water available and its movement. A major objective should be to view hydrological processes in relation to the environment as well as human activities, emphasising the multi-purpose utilisation and conservation of water resources to meet the needs of economic and social development throughout the area. Water management, especially in this semi-arid area, should strive towards the formulation and implementation of a sustainable socio-economic development policy with corresponding regulations and guidelines (Assaf 2004a).

\section{Yemen}

In some cases dating back roughly 2000-3000 years, Yemen's water rights systems have long defined the usage of groundwater at the base of the Arabian Peninsula. The old rules dictate that the right to water usage is determined by land ownership; people have the right to use the groundwater that flows under their land. These rules stem from times when upstream users used a marginal quantity of the groundwater flow, leaving ample resources to their downstream neighbours. Today, however, water is scarce, and with everyone trying to use as much as possible, those residing downstream are losing their drinking water. Groundwater use and the correspondent drop in the water tables have been the main elements in the water debate in Yemen for the last twenty years. In recent years, a number of doomsday scenarios were predicted. While the problems are undeniable, the gloomy predictions have yet to materialise. This does not mean that groundwater problems are not serious. One can, for example, point to real 
disaster spots - areas abandoned as falling groundwater tables undermined the resource base - causing considerable drama in, for instance, coastal Tihama and Al Munjelis. What was once a lush and important date growing region has gradually become a barren dune area, forcing local inhabitants to turn to marginal economic activities like fishing. Largely responsible for the desertification in this area is the construction of an upstream dam that prevents groundwater recharge for the Al Munjelis area (Taher et al. 2012).

The response to severe groundwater threats in Yemen have come in the form of intensive study and institutional development in the shape of the National Water Resource Authority, its branch offices and the announcement of the National Water Law. Yet, despite all of these initiatives, effective groundwater management or any significant action on the ground have yet to be realised. While there have been checks and balances in local conflicts between users, these have yet to result in substantial improvement in groundwater governance regimes. The GP study aims at contributing to these improvements by making different interests like upstream and downstream interests more transparent. Specific topics to be considered in this are the role of conflict in catalysing cooperation, the vigour of local governance and the role of formal regulation, and adaptation to extreme scarcity. A video series has been completed for dissemination among farmer groups and local players to stimulate debate on groundwater conflict and cooperation.

\subsection{THE ROLE OF POLITICS}

Politics is regarded either as 'what politicians do' or as 'activity through which people make, preserve and amend the general rules under which they live' (Heywood 2004: 4-5). A division has to be made between general politics and politics as practised by those appointed or elected. The decision-making processes can be analysed at different levels, from international to local. However, the political decision-making process is often considered to be a black box. Many theories exist about what happens inside this box and how decisions are made (e.g. the stream model, garbage can model, barrier model) (Tromp 2007). So too, the political black box is further influenced by historical, economic and social factors, among many others, that exist outside of the box (GP Consortium 2012).

Political theories of natural resource management have several important themes, but two themes are recurrent: 'political interest' and 'political will' (Mollinga 2008). Political interest describes the positions of those that can influence or have political power as having an interest in the way resources are allocated and used. Political will describes the agenda of the political leadership and their engagement in resource management. This political will can be seen as something that can be influenced by lobbyists and agenda setting, and is therefore more flexible than political interest. There are two different dimensions behind these two themes: the state (and those persons that are close to the centre of power) as a player and the state as a guardian (taking care of public interest in a selective and sometimes limited way). Though the balance between the two dimensions is different for various broad types of state or enabling environments, as will be discussed later, they nevertheless co-exist and are interdependent. 
Connecting individuals within the political spheres can give actors from outside access or leverage to the political system. These connections can have either a professional or personal background. They also enable an exchange of knowledge. Moreover, the better the connection between the individuals within the political sphere, the higher the chance that the issue is addressed within the political system (Mollinga 2010).

Different concepts help to clarify political interest and political will. In political interest it is important to first understand the force field of interests that make up the political power and then to see how these are linked to the manipulation of allocation or use of natural resources. The process of granting concessions and deciding on investment is generally not a black box, even in less democratic countries. Another important and useful question is how differences in knowledge, information, negotiation skills, organization, etc. can function as manipulative instruments and examples of soft power mechanisms (Zeitoun et al. 2010). Depending on their relative importance for social, political and economic purposes, there is also a large difference in the degree to which different resources influence this process. As Witsenburg and Roba (2007) explain, the cooperation for certain resources might appear unlikely, but may sometimes occur unexpectedly.

'Span of control' is an important concept to understand political will. Though there is a tendency to suggest that politics is all-pervasive or that 'everything is political', this is not necessarily the case. There are two factors that set the boundaries. The first factor is that some issues and options are within the control of the political leadership, whereas others are beyond it. A grey area exists between these two extremes. The position of a state in this grey area differs. The second factor is that 'there is only so much' that a political state can be involved in. It cannot be engaged in every issue, let alone control it. As we will discuss later, the reach of what it can be involved in differs. There may also be intervening factors - issues that because of their urgency or appeal take precedence. These issues include perceived insecurity, secessionist movements, terrorism or issues that have strong actors as mediators. Fourthly, exploitation and allocation are generally easier in resource development and hence more attractive to a state in the short run than resource regulation and management. This is further explained by a lack of (good) governance and control (Wolf et al. 2005). An example of this is the success China has in leasing fertile land in parts of Africa despite food scarcity. It is important to overcome short-term thinking and work towards long-term safeguarding of the resource for future generations.

Opening the 'political black-box' requires a detailed analytical approach that first considers which decision-making is part of the political domain and, secondly, examines how decision-making in politics functions and is influenced by power distribution, perceptions, and strategic and tactical decision making.

\subsection{A TYPOLOGY OF POLITICAL STATES}

The political state of a country is directly related to the ways in which political interest and political will take shape, as well as the ways in which governance deals with conflicts - at times even encouraging them - supports cooperation and leaves certain (burning) issues in a void. Consequently, these aspects differ greatly from country to 
country, and the type of political state is one of the most important factors influencing the decision-making processes, including those that concern water management.

We distinguish between four types of political states:

- Autocratic states (Wittfogel 1959) - centred on (often personalized) leadership either balancing different interest groups or maintaining control through security and force. There can be many types of autocratic states. Linz, for instance, identifies six different types (Tromp 2007: 333).

- Democratic states - where a broad range of public interests in the country is articulated and balanced. ${ }^{13}$

- Exclusive states - where there is an officially defined distinction between different groups, e.g. on the basis of race, religion or ethnicity and power is in the hands of one group only (in case of exclusive democracies) or where leadership has its powerbase in and favours one group (exclusive autocratic states).

- Fragile states - where the basic balance in power and representation is lost and power shifts are the order of the day.

This is a broad generalisation, one that is meant to see and predict patterns. At this point it is also important not to equate democracy with elections as elections occur in many forms and in many polities. Similarly, it is important to analyse and understand rather than judge; democratic or autocratic forms for instance may be the reflection of the structure of society or the stage of development it is in. Palestine and Yemen can best be characterised as fragile states, while Ethiopia is a democratic state in development with elements of an autocratic state.

The way these different states deal with political interests, political will and the management of conflicts, voids and cooperation is given in table 5.1.

\subsection{FACTORS OF CHANGE}

The question how do things change - in particular how do they change for the better is vital to our research. Equally important is the question of whether political actions can improve management over resources like groundwater. These questions, in turn, lead to others: should we use terminologies that inevitably include normative or ethical aspects or restrict ourselves to more or less quantifiable parameters such as fewer confrontations, more cooperative actions, higher organizational order, and increased sharing of information? Will understanding the mechanisms of change also imply the ability to steer changes? These questions are deeply rooted in the social sciences and touch on fundamental philosophical issues concerning our views of evolution, history, information, reality and the function of time. By zooming in and out of different scale events, between normal and more extreme occurrences in a qualitative and descriptive approach, one may gain understanding of the coherence of facts, even without the

\footnotetext{
${ }^{13}$ Including 'the developmental state' - i.e. Ethiopia, but also Vietnam, China - autocratic or democratic (Mollinga and other papers from Water Alternatives theme number on Water, Politics and Development, 2008).
} 
Table 5.I State types and the management of conflicts, voids and cooperation.

\begin{tabular}{|c|c|c|c|c|}
\hline & $\begin{array}{l}\text { Politic power and } \\
\text { resource use }\end{array}$ & $\begin{array}{l}\text { Political will and } \\
\text { resource } \\
\text { management }\end{array}$ & $\begin{array}{l}\text { Dealing with } \\
\text { conflict, void and } \\
\text { cooperation }\end{array}$ & $\begin{array}{l}\text { Attention for role } \\
\text { of local actors in } \\
\text { governance }\end{array}$ \\
\hline Democratic & $\begin{array}{l}\text { Resources use } \\
\text { for at least short } \\
\text { term public } \\
\text { interest }\end{array}$ & $\begin{array}{l}\text { Broader agenda } \\
\text { setting } \\
\text { process - but } \\
\text { short term/own } \\
\text { interest may } \\
\text { prevail }\end{array}$ & $\begin{array}{l}\text { Certain degrees } \\
\text { of accountability } \\
\text { Violent conflicts } \\
\text { disliked }\end{array}$ & $\begin{array}{l}\text { Large degree of } \\
\text { attention for local } \\
\text { arena, actors are } \\
\text { given the chance to } \\
\text { cooperate with the } \\
\text { political domain }\end{array}$ \\
\hline $\begin{array}{l}\text { Exclusive } \\
\text { states }\end{array}$ & $\begin{array}{l}\text { Certain groups } \\
\text { systematically } \\
\text { excluded/ } \\
\text { marginalized } \\
\text { from use }\end{array}$ & $\begin{array}{l}\text { Hidden agendas } \\
\text { overrules natural } \\
\text { resources } \\
\text { management }\end{array}$ & $\begin{array}{l}\text { Discrimination } \\
\text { and } \\
\text { disempowerment } \\
\text { embedded }\end{array}$ & $\begin{array}{l}\text { Large differences in } \\
\text { influence of local } \\
\text { actors }\end{array}$ \\
\hline Autocratic & $\begin{array}{l}\text { Access to } \\
\text { resources } \\
\text { monopolized }\end{array}$ & $\begin{array}{l}\text { Small span of } \\
\text { control? } \\
\text { 'Difficult' natural } \\
\text { resource } \\
\text { management } \\
\text { left unaddressed } \\
\text { irrespective of } \\
\text { their importance }\end{array}$ & $\begin{array}{l}\text { Formal } \\
\text { institutions are } \\
\text { isolated from } \\
\text { power or } \\
\text { used by it } \\
\text { Conflict may be } \\
\text { fomented } \\
\text { State monopoly } \\
\text { on violence }\end{array}$ & $\begin{array}{l}\text { Local actors are } \\
\text { means to express } \\
\text { central power }\end{array}$ \\
\hline Fragile & $\begin{array}{l}\text { No state } \\
\text { monopoly on } \\
\text { important } \\
\text { resources }\end{array}$ & $\begin{array}{l}\text { No span of } \\
\text { control } \\
\text { Political attention } \\
\text { diverted away } \\
\text { from resource } \\
\text { management }\end{array}$ & $\begin{array}{l}\text { Little recourse } \\
\text { to formal } \\
\text { institutions } \\
\text { Catch as catch } \\
\text { can situations } \\
\text { No state } \\
\text { monopoly on } \\
\text { violence }\end{array}$ & $\begin{array}{l}\text { Often large } \\
\text { influence and } \\
\text { power for local } \\
\text { actors and } \\
\text { complicated } \\
\text { relations between } \\
\text { local actors and } \\
\text { central power }\end{array}$ \\
\hline
\end{tabular}

implementation of quantitative tools like statistical data analysis. In doing so, the theoretical framework further develops itself. Patterns of cooperation and conflict may emerge for particular cases. Another extreme may be the absence of patterns or pure randomness. Our assumption, however, is that clear patterns will manifest themselves as self-similar patterns in system dynamics, visible at different scales, that evolve overtime into new patterns. Changes appear both as a result of gradually evolving processes and as the product of rapid processes occurring at the tipping points of systems or when the system crosses boundaries (Meerts 2011).

We have asked ourselves if mainstream social theories, views of societal changes and views of physical changes can be combined in any way. A very important concept that connects physical and societal change views - and also confuses many debates - is entropy. In classical physics, entropy is the amount of energy that is not available for work anymore like the rest heat of a motor dissipated over the environment. Due to 
its dissipative nature entropy became associated with chaos. The second law of thermodynamics, which describes the increase of entropy or chaos in a closed system, was translated in more popular terms. For example, natural processes, and even evolution, tend towards an increase in chaos. As evolution also produces more and more complex ordered systems, the term negentropy was introduced to describe the driving force behind evolutionary change. When the concepts of entropy and negentropy became increasingly useful in information theories in the late 1940s, the quest for applications in social theories commenced as well. The application to the latter resulted in more confusion than it did find concrete results. ${ }^{14}$ In this study, the entropic and negentropic elements of conflict and cooperation, especially in fragile states and young democracies like study areas, will be further analysed. The concept of void will be analysed from the point of view of a local optimum in entropy in a closed system that can only be overcome by an external or new source of energy, be it in the form of innovation, economic or political development. ${ }^{15}$

Change can come from all the spaces of governance as well as the interactions between them. An enabling environment, either triggered by progress in politics, economics or the social domain, helps actors develop themselves, the resource and inspire others (ter Horst 2012). This can best be explained through an example. During our work in Ethiopia, we discovered agents of change. With the assistance of a national program, young men from the city rented a piece of land in the country side and started to grow crops using drip irrigation as a new technology. The owner of the land was then hired as a seasonal labourer, on hand to tend to the planted crops. The yield appeared high due to the new techniques and crops used, inspiring others to replicate the practice. In this area, these changes are very important as the people often depend on food aid. These agents of change worked in a political context that stimulated these processes and the results are well perceived by the local communities, hence the change process is embedded both at micro and macro level. In terms of spaces of governance, it can be stated that the top-down and bottom-up processes are reinforcing each other in this particular example. Where agents of change in different spaces of government are interfering, patterns of change can originate and be propagated efficiently and effectively. The overall political context in Palestine and Yemen is much more complicated. Hence, internal and external agents of change face more difficulties and require creative strategies to find appropriate spaces of change.

Agents can be national, but also local - focusing on states is important, but how this translates to the local level is most important, as this is where the resource is used. In our research we have moved to the more practical stages of political action plans where changing positions of stakeholders is a key issue (see figure 5.2). Outcomes of the analysis will further shape the theoretical framework.

\footnotetext{
${ }^{14} \mathrm{See}$ http://www.preposterousuniverse.com/blog/2013/01/29/social-entropy/ and http://en .wikipedia.org/wiki/Social_entropy (accessed September 10, 2013).

${ }^{15}$ The concepts of entropy and negentropy and its relationship with groundwater management are further explored in the upcoming special issue of the International Water Governance Journal on Anarchy: the "dark" side of water governance? (Smidt et al. forthcoming).
} 


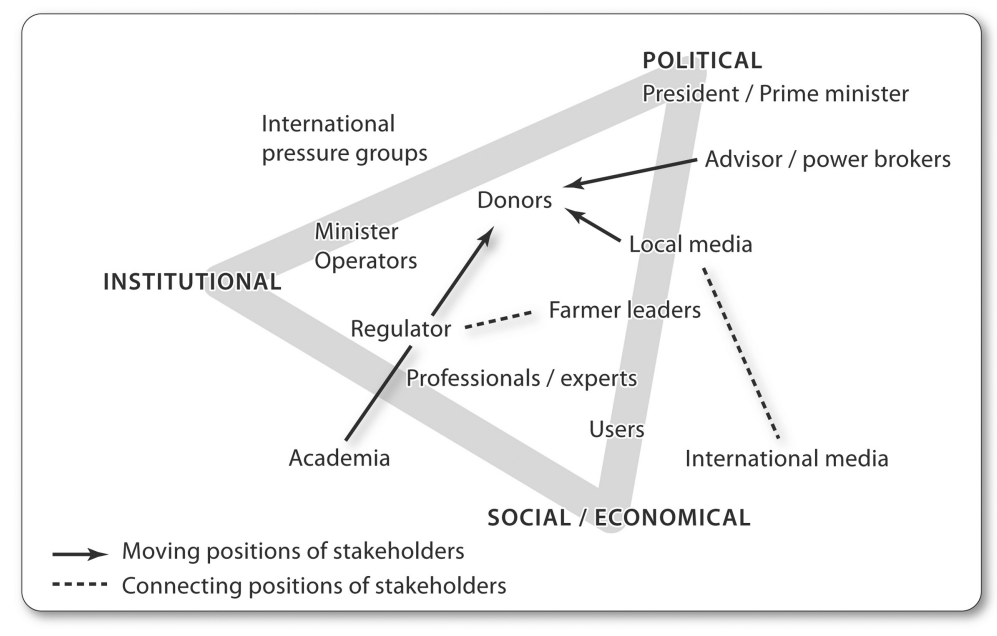

Figure 5.2 Moving (solid lines) and connecting positions (dotted lines) of stakeholders in the GPP context.

\subsection{CONCLUSION AND DISCUSSION}

The building blocks from the socio-economic, institutional and political domains explained in this chapter all lead to a better understanding of the complexity of groundwater management and the governance regimes in the different field situations. Theoretical work on governance regimes and its levels and scales, the relation between conflict, cooperation and the political black box, the role of politics and different types of states, and factors of change is useful and needs further development in order to fully grasp the complexity of the data from the three case studies. One of the main lessons to be learned is to allow the narrative of the cases to take into account the interaction between the resource, groundwater in our case, the different users and the researchers. This process is dialectical by nature and is considered special enough to be dealt with in further analysis from a hydrolectical point of view ${ }^{16}$ (Linton, 2010; Smidt et al., in prep.). In conjunction with the considerations in this chapter, such a framework offers guidance for a theoretical understanding of what is happening in the field.

In addition to these theoretical building blocks, some important practical leads have been identified that help to further develop the interaction between theory and action-based research in the project:

1 Describing and comparing patterns of the interaction between conflict, cooperation and change is considered the main challenge of the present work. Existing practical and/or theoretical pattern descriptions can be useful, but the cases themselves will deliver the specific patterns. The narrative will be as important as the

\footnotetext{
${ }^{16}$ Hydrolectics assumes a dialectical water-mankind relation as in 'water is what we make of it'.
} 
analysis. The Groundwater in the Political Domain project will test intervention strategies, following changes in the negotiation scene and the development of new dynamics of change as new players are brought in and perspectives of stakeholders are shifted from within or outside the political black box. Dissecting the political black box and not being afraid of seeing the human actors behind the large political puppets is therefore essential.

2 Change implementation includes negotiations between stakeholders. Boundaries in negotiations are needed on the one hand and can prevent 'thinking out of the box' on the other. In the development of any framework, attention will be given to these boundary effects (Meerts 2011).

3 Water frameworks to translate risk factors related to political violence and war into multi-level preventive interventions can profit from work done in the public health domain. More coordination of the work done in different sectors is needed and the integration of findings will be useful. The presentation of the GPP-results at the 6th WWF in Marseille in the context of existing solutions for water conflicts in a variety of situations is a useful start for the development of intervention strategies.

Much remains to be done in the project. At the field level, the project aims at initiating more cases studies - shifting towards other distinct groundwater hotspots in each of the three countries (up scaling). In Ethiopia, the project will work on regional groundwater conflicts around fast growing urban areas, in particular in the Oromyia Special Zone around Addis Ababa, and also venture into conflicts around groundwater in pastoralist areas, a direction that follows on from the recommendations received during local stakeholder consultations. In Palestine, the project will start to work in other water scarce areas and translate the findings in a national analysis, while in Yemen the idea is to focus on three more areas, taking on board governance around urban areas and fortifying the findings with economic analysis where possible, with the aim of reflecting this in briefs for policy makers and politicians.

Lessons learned from the field studies are incorporated in governance issues at country level and strongly linked to international debates. This will be done by contributing to policy studies in Ethiopia, Palestine and Yemen, preparing policy briefs and having systematic meetings, including using informal opportunities to raise points. In Palestine this will also be done by cooperating with the MYWAS-WEAP project team, which analyses the economic effects of different political and water allocation strategies, thereby assisting the preparation of water negotiations (Smidt et al. 2013). The GP project will contribute to the scenario determination and the feedback mechanism for different political and stakeholder levels. Contributions to international debates and framework developments will continue, especially with regard to the debate on groundwater governance at global level and at the Dutch national level. The international groundwater governance is brought together in a Framework for Country Action that is supported by FAO, IAH, GEF, UNESCO-IHP and World Bank. In this project a Vision and Framework for Country Action will be developed, and will most likely be followed by an international code of conduct for country groundwater governance. The analysis of the narratives from the three case analyses is supportive to this process.

Gradually the project will be able to develop more explicit methodologies that can be applied in other situations as well. The execution of political action plans in 
2013 will help to better understand what is happening inside the political black box and how the linkages between the socio-economic domain (including the patterns of groundwater use) and the institutional domain function. A great deal has already been learnt. As a result of the case work, there is a better understanding of (1) how national level political systems actually work and how they affect priorities for groundwater management and local processes of allocation, regulation, investment and facilitating access; (2) what the remit of the political systems is - in other word what gets 'politicized' and how and where are the boundaries of the political 'ability to act' (a concept as important as the 'will to act'); and (3) how 'voids' come to exist and what perpetuates them (i.e. areas where the resource is degrading but nothing happens in terms of conflict or cooperation). The integration of these elements forms the challenge of linking existing knowledge with innovative research and experimentation.

\section{REFERENCES}

Amnesty International. 2009. Troubled waters - Palestinians denied fair access to water. United Kingdom: Amnesty International Publications.

Assaf, K. 2004a. “The Need for Joint Management and Monitoring of the Water "Usage” Cycle: The Israeli-Palestinian Case with an International Perspective" In Management of Shared Groundwater Resources, ed. E. Feitelson and M. Haddad, 75-82. Ottawa: International Development Research Centre.

Assaf, K. 2004b. "Water as a human right: the understanding of water in Palestine." Global Issue Papers 11.

Bai, Z. G., D. L. Dent, L. Olsson, and M. E. Schaepman. 2008. Global assessment of land degradation and improvement. 1. Identification by remote sensing. Report 2008/01 (GLADA Report 5). Wageningen: International Soil Reference and Information Centre.

Collier, P. 2010. The Plundered Planet. Why We Must-and How We Can-Manage Nature for Global Prosperity. Oxford: Oxford University Press.

Costanza, R., R. d'Arge, R. De Groot, S. Farber, M. Grasso, B. Hannon, K. Limburg et al. 1997. The value of the world's ecosystem services and natural capital. Nature 387, no. 6630: 253-260.

Derman, W., R. Odgaard, and E. Sjaastad (Eds.) 2007. Conflicts over land and water in Africa. Oxford: James Curry.

Dietz, T., E. Ostrom, and P. C. Stern. 2003. The struggle to govern the commons. Science 302, no. 5652: 1907-1912.

Feitelson, E. and I. Fischhendler. 2009. Spaces of water governance: The case of Israel and its neighbors. Annals of the Association of American Geographers 99, no. 4: 728-745.

Folke, C., T. Hahn, P. Olsson and J. Norberg. 2005. Adaptive governance of social-ecological systems. Annu. Rev. Environ. Resour.30: 441-473.

Galema, F. M., 2012. Wielded water. An analysis of the effects of the Palestinian - Israeli water regime on water governance and agriculture in Qalqiliya, the West Bank. MSc Thesis, WUR/TUD.

GP Consortium. 2012. CoCooN-Integrated Project. Groundwater in the political domain, 1 st \& 2nd Report. Sana'a, Yemen.

Gray, B.1989. Collaborating: Finding common ground for multiparty problems. Vol. 329. San Francisco: Jossey-Bass.

van der Gun, J.2012. Groundwater and Global Change: Trends, Opportunities and Challenges. UN WWAP 4WWDR Side Publications Series No. 1. Paris: UNESCO.

Hardin, G. (1968). The tragedy of the commons. Science, 162, 1243-1248. 
Heywood, A. 2004. Political theory: an introduction. Basingstoke: Macmillan.

Johnson, V., I. Fitzpatrick, R. Floyd, and A. Simms. 2011. What is the evidence that scarcity and shocks in freshwater resources cause conflict instead of promoting collaboration?CEE review: $10-010$.

Jong de, J.T.V.M. 2009. Het tij van biologie en cultuur: een Nederlands perspectief. Paper presented at the 25th Anniversary Conference Mikado, April 23rd, 2009.

Krasner, S. D. (1983). International regimes. Ithaca NY: Cornell University Press.

Kumsa, A. 2011. Pathways to Greater Food Production: Lessons from Ethiopia. Paper presented at the Water for Food Conference 2011, Nebraska.

Lieshout, van M., A. R. P. J. Dewulf, M. N. C. Aarts and C. J. A. M. Termeer. 2011. Do scale frames matter? Scale frame mismatches in the decision making process of a 'mega farm' in a small Dutch village. Ecology and Society 16, no. 1.

Linton, J. 2010. What is water?: the history of a modern abstraction. Vancouver: UBC Press.

Low, B. S. 2010. Sustainability and sources of wealth. Science 329: 904.

Meerts, P. 2011. Boundaries in Bargaining: A Multidimensional View. Group Decision and Negotiation 20, no. 2: 155-164.

Millennium Ecosystem Assessment. 2003. Ecosystems and Human Well-being: A Framework for Assessment. Washington: Island Press.

Mollinga, P. P. 2008. Water, politics and development: Framing a political sociology of water resources management. Water alternatives 1, no. 1: 7-23.

Mollinga, P. P. 2010. Hot water after the Cold War-Water policy dynamics in (semi-) authoritarian states. Water Alternatives 3, no. 3: 512-520.

Ostrom, E.1990. Governing the commons: The evolution of institutions for collective action. Cambridge: Cambridge University Press.

Ostrom, E. 1999. Coping with tragedies of the commons. Annual review of political science 2, no. 1: 493-535.

Ostrom, E., J. Burger, C. B. Field, R. B. Norgaard, and D. Policansky. 1999. Revisiting the commons: local lessons, global challenges. Science 284, no. 5412: 278-282.

Rutten, M. and M. Mwangi. Ignoring another inconvenient truth? Challenges in managing Africa's water crisis. ASC Infosheet 5. Leiden: Africa Study Centre.

Sado, E.V. and B.F. Carswell. 1987. Surficial Geology of Northern Ontario [map]. 1:1,200,000. Ontario Geological Survey Map 2518. Toronto: Ontario Geological Survey.

Selkhozpromexport. 1990. BaroAkobo Basin Master Plan Study of Water \& Land Resources of Gambela Plain (Draft). USSR, Moscow, Ethiopian Valleys Development Studies Authority. Volume IV: 198.

Steenbergen, F. van and N. El Haouari. 2011. The Blind Spot in Water Governance: Conjunctive Groundwater Use in the MENA Countries.

Smidt, E. and B. Satijn. 2013. Groundwater governance: a decisive factor in resilience strategies. Den Haag: Water Governance Centre.

Smidt, E., I. van der Molen, L. Boerboom, and R. Ter Horst. 2013. The changing role of water in the Israeli-Palestinian conflict (in Dutch). Internationale Spectator no. 3: 42-47.

Smidt, E. et al. forthcoming Hydro-entropy as a tool to understand the complexity of hydropolitics: theory and application on the Israeli-Palestinian water distribution," Special Issue in the International Water Governance Journal - Anarchy: The Dark side of Water Governance? no. $1 / 14$.

Taher, T., B. Bruns, O. Bamaga, A. Al-Weshali, and F. van Steenbergen. 2012. Local groundwater governance in Yemen: building on traditions and enabling communities to craft new rules. Hydrogeology Journal 20, no. 6: 1177-1188.

Tams, U. 1997. Baro-Akobo River Basin Integrated Development Master Plan Study. Natural Resources. Addis Ababa, Ministry of Water Resources. Annex 2: 170.

Ter Horst, R. 2012. Facing barriers. The analysis of water governance in the West Bank, Palestinian Territory. MSc Thesis, University of Amsterdam - GPP Project. 
Tromp, B.2007. De wetenschap der politiek. Amsterdam: Amsterdam University Press.

Turton, A. 2010. The politics of water and mining. In The Politics of Water: A survey, ed. K. Wegerich and J. Warner. London: Routledge.

United Nations. 2012. We can end poverty 2015. United Nations. Accessed July 2, 2012, http://www.un.org/millenniumgoals/

United Nations. (1997). Convention on the Law of Non-Navigational Uses of International Watercourses. Retrieved from http://untreaty.un.org/cod/avl/ha/clnuiw/clnuiw.html, August 13, 2012.

Vollan, B. and E. Ostrom. 2010. Social Sciences: Cooperation and the Commons. Science 330, no. 6006: 923-924.

Wijnen, M. B. Augeard, B. Hiller, C. Ward and P. Huntjes. 2012. Understanding and Improving Groundwater Governance (draft report). Water Papers: World Bank.

Witsenburg, K. M. and W. R. Adano. 2005. The use and management of water sources in Kenya's drylands: Is there a link between scarcity and violent conflicts? In Citizenship, identity and conflicts over land and water in contemporary Africa, ed. R. Overgaard and E. Sjaastad. London: James Currey.

Wittfogel, K.A. 1959. Food and society in China and India: human nutrition, historic and scientific. New York: International Universities Press.

Woldie, N. T. K. 1996. Geological Map of Ethiopia. T. C. a. W. H. MengeshaTefera [map]. Addis Ababa: Ethiopian Institute of Geological Surveys.

Wolf, A. T., A. Kramer, A. Carius, and G. D. Dabelko. 2005. Managing water conflict and cooperation. State of the World 2005: Redefining Global Security: 80-95.

Zeitoun, M. and N. Mirumachi. 2008. Transboundary water interaction I: Reconsidering conflict and cooperation. International Environmental Agreements: Politics, Law and Economics 8, no. 4: 297-316.

Zeitoun, M., N. Mirumachi and J. Warner. 2010. Transboundary water interaction II: The influence of 'soft' power." International Environmental Agreements: Politics, Law and Economics 11, no. 2: 159-178. 


\title{
Harms, crimes and natural resource exploitation: A green criminological and human rights perspective on land-use change
}

\author{
Damián Zaitch',Tim Boekhout van Solinge' \& Gudrun Müller²
}

\begin{abstract}
This chapter claims that a 'green criminological' perspective can be used fruitfully for conceptualizing and researching the exploitation of natural resources and, more specifically, the processes of land use change and land grabbing that take place in many countries (closely connected, for example, to the expansion of agrofuel monocultures, deforestation for timber, the construction of mega-hydroelectric dams, or increased large-scale commercial mining activities). This perspective offers the possibility of simultaneously focusing on three interrelated issues. First, if criminal offences are involved, we can analyze who the perpetrators are, how illegal mechanisms operate and why these illegal practices take place. Second, this perspective can reveal the victims, as well as identifying the social and environmental harms surrounding the exploitation of natural resources. Finally, a green criminological approach also focuses on the 'rights' that are being violated (whether constitutional, human, environmental, social, etc.), the social initiatives to defend them (communities affected, NGO's), and the measures and interventions taken (or not) by private, state or international actors to guarantee, protect and enforce them. After presenting what a green criminological perspective would imply for the study of land-use change, the article finishes by briefly focusing on two particular cases being researched in Colombia and Brazil.
\end{abstract}

Keywords Land-use change, green criminology, human rights, Brazil, Colombia.

\section{I INTRODUCTION}

The aim of this chapter is to present and discuss a green criminological perspective and human rights based approach (HRBA) for studying the exploitation of natural resources and, more specifically, the process of land-use change and land grabbing taking place in Latin America. To that end, we will use the ongoing LAR project, ${ }^{3}$ in which the authors are involved, as an illustration of how these two approaches can be applied in practice. The LAR project aims to describe and explain the conditions,

\footnotetext{
${ }^{1}$ Willem Pompe Institute for Criminal Law and Criminology, Utrecht University, Netherlands (Corresponding author: D.Zaitch@uu.nl)

${ }^{2}$ FIAN (Food First Information and Action Network) International, Dutch Section, Amsterdam ${ }^{3}$ Information about the Lands and Rights in Troubled Waters (LAR) project can be found at http://www.landsandrights.blog.com
} 
nature and effects of land-use change in the Cauca (Colombia) and Tapajós (Brazil) basins. This land-use change is closely connected to the explosive expansion of sugar cane and soy monocultures in Cauca and Tapajós respectively, growing deforestation, the increased commercial large-scale exploitation of mineral resources in both areas, and the development of mega-projects using water resources such as hydroelectric power plants. Both cases present different forms of conflict, social and environmental harms, and human rights violations.

Although the LAR project involves researchers from various disciplines, including legal scholars, environmental biologists, anthropologists, sociologists, geographers, social workers and activists, it mainly adopts innovative methodologies and critical perspectives from the growing field of green criminology in combination with a HRBA. The LAR project seeks to promote a HRBA to development by strengthening organizations and communities in their claim for rights and environmental justice. It aims to learn from the conflicts, identifying actors and understanding mechanisms behind the production of social and environmental harm and human rights violations. It seeks to strengthen environmental and human justice, pressing for participatory public policies 'from below' with respect to extractive industries, land rights and water management. In the LAR project, the HRBA and green criminological perspectives are combined with challenging and innovative research methodologies such as ethnography, social cartography and participatory action research.

Issues around land-use change and the exploitation of natural resources have traditionally been addressed by economists, social geographers, political and environmental scientists, and, particularly, development specialists. Human rights activists have increasingly been engaged in conflicts, debates and campaigns surrounding landuse change and land grabbing, but these issues are equally a fertile soil to be tackled by criminologists, in particular green criminologists. As we will explain in this chapter, green criminologists essentially study global and local environmental harms and crimes from a criminological perspective, focusing on the interplay between corporate or individual perpetrators, environmental victims, criminal justice responses (laws, regulations, law enforcement) and broader social developments (Beirne and South 2007; White 2008; 2011).

A green criminological perspective offers the possibility of simultaneously focusing on three interrelated issues. Firstly, the perspective allows us to analyze who the perpetrators of criminal or harmful behaviour are, how legal/illegal mechanisms operate and intertwine at micro and macro levels, and why these practices take place. Secondly, such a perspective can reveal who the victims are and which social and environmental harms can be identified when it comes to the exploitation of natural resources. Finally, this perspective also pinpoints the 'rights' being violated (whether constitutional, human, environmental, social, etc.), the social initiatives that defend them (communities affected, NGOs), and the measures and interventions that are put in place (or not) by private, state or international actors to guarantee, protect and enforce those rights. In this way, the framework of the LAR project is establishing fruitful cooperation between green criminologists and human rights defenders.

Although the ideas and associations that average readers establish with criminology vary a great deal, they usually revolve around police investigations, street crime, serial killers or criminal risk profiling. We will first briefly explain how various concepts and discussions have emerged within criminology in the last sixty years that are 
useful for understanding the processes tackled here. Before focusing on the specific contribution of a HRBA and green criminological perspective to the study of conflicts related to the exploitation of natural resources, we will introduce the concepts of corporate and governmental crime, criminalization, and the notion of harm. We will subsequently try to show how this theoretical framework is being applied in the LAR project's two concrete cases. Finally, some discussion points will be presented for further debate.

\subsection{CRIME, HARM AND CRIMINOLOGY}

Traditionally, criminology's central focus of study has been crime, law-breaking behaviour and the responses to it (Walklate 2007: 5). Defined in this way, criminology can be considered an 'object' discipline, finding its epistemological grounds in so-called 'mother' disciplines, particularly social sciences (mainly sociology and psychology) and law. Moreover, such a demarcation of criminology's study terrain appears to imply that the law, and particularly criminal law, is used as the reference point (norm) in defining which behaviour is criminal and which is not. Laws, however, are variable in time some acts are legal at one point in time and illegal in another-as well as in place -what is legal in one system of law is illegal in another. Since what is considered a 'crime' differs in time and place, many criminologists consider crime to be a social construct. The social problems or behaviours that are criminalized (defined and treated as a crime in a given time and place) are a matter of cultural practices, social constraints and political (power) relations. Even acts that are seemingly generally condemned, such as theft, rape or murder, are tolerated or even stimulated in some situations, such as during war and other armed conflicts. Property laws and law enforcement, for example, are very selective and mainly reflect the interests of those owning property or powerful enough to seize it. A landless peasant unlawfully trespassing a fence might be criminalized and sent to prison, while a large entrepreneur in the same area unlawfully grabbing land (by faking titles, corrupting officials or using 'security' personnel) might be seen by the authorities as an agent of 'progress and development'. Hence, two criminal acts of the same kind can be dealt with in a totally different way.

If crime is a social construct, the question is whether criminology should limit itself to study harmful behaviour that has been defined as a crime. The discussion is very old in American criminology. In his pioneering work, Swedish-American criminologist Thorsten Sellin (1938) argued that conduct norms embodied in criminal law impose 'artificial boundaries' on the discipline. Thus, in order to find more scientifically valid and accurate crime causation theories, criminologists should really focus on the extralegal conduct norms of various social groups in society. He set cultural phenomena, beyond legally defined or officially recorded crime, at the basis of the study of criminal conduct.

It was the American sociologist Edwin Sutherland (1940; 1983) who really broadened the object of criminology with his path-breaking concept of 'white-collar crime'. Despite much discussion about how inclusive the concept should be, white collar crime can be broadly defined as "illegal or unethical acts that violate fiduciary responsibility of public trust committed by an individual or organization, usually during the course 
of legitimate occupational activity, by persons of high or respectable status for personal or organizational gain" (Helmkamp, Ball and Towsend 1996: 351). Sutherland (1940; 1983), and all scholars after him studying this phenomenon, found that one of the intrinsic characteristics of white collar crime is that it entitles behaviour that is not primarily dealt with by criminal courts (he found it only in $17 \%$ of the cases of law breaking), but more often by administrative and civil law and regulations. It constitutes 'socially injurious acts' (in fact more harmful than petty crime or crimes from the lower classes). While criminal law mainly deals with criminals of low status, the transgressions of highly respected individuals (in the course of their occupation) or companies are not considered and treated as real crimes by the law, the general public or many criminologists.

A third main source for expanding the scope of criminology comes from the 'social constructionist' or 'labelling approach' to crime that was developed in the 1960s by sociologists such as Howard Becker (1963). Considering the variety and changeability of 'crime', criminology should also be concerned with understanding the processes by which certain behaviours come to be defined as criminal (Walklate 2007: 5). Laws are the result of norms, morals and the influence of so-called 'moral entrepreneurs' (Becker 1963), persons seeking to influence a group to adopt and enforce a certain norm. Some moral entrepreneurs are more successful than others in getting the necessary support for having particular forms of harmful behaviour condemned in a formal way by means of criminalization.

Which actors have sufficient power and possibilities to have certain behaviours that they consider undesirable or harmful to be criminalized? Becker notes that a 'moral crusade' by the so-called moral entrepreneurs is usually more successful when they have influential positions - i.e. they belong to the upper social strata of society. Some actors, usually those in more socially privileged positions, have better access to the criminal justice system than others. These premises and questions have profound implications for the study of crimes and harms regarding the exploitation of natural resources, as they might highlight how processes of criminalization do or do not take place.

Taking Sellin's $(1938)$ and Sutherland's $(1940 ; 1983)$ criticism of the restrictive, legalistic understanding of crime further, Herman and Julia Schwendinger advocate that we should assess the criminality of acts according to their infringement of basic human rights (Schwendinger \& Schwendinger 1970: 117). With human rights as the main criterion for defining crime, they perceive criminals as those individuals, social relationships or social systems that deny others the fulfilment of rights "absolutely essential for the realization of a great number of values [...] in many spheres of life" (Schwendinger and Schwendinger 1970: 136-137). This notion of crime as a human rights violation is an important input to a HRBA within or complementary to a criminological approach to harms and crimes in natural resource exploitation.

This expansion in the criminological notion of crime to include other forms of law or norms breaking, or to talk about crime when human rights are being violated, is an essential prerequisite when thinking and researching about so-called 'crimes of the powerful' (Pearce 1976). Building upon Sutherland's (1940; 1983) concept of white collar crime, this notion takes the concept further and frames it in a political economy approach to crime, focusing on the interactions between society's class structure and struggles, ruling class ideology, the state, and the functions of the criminal justice 
system in global capitalism. Despite their remarkably harmful nature, 'crimes of the powerful' are not always defined as criminal offences, but most often encompass a mix of legal, unethical, illegal and criminal practices by powerful actors.

There are four interrelated subcategories of 'crimes of the powerful' that are particularly interesting for the theoretical perspective taken here. First, we use the notion of 'corporate crime', which refers to illegal offences and harmful acts committed by officers and employees of corporations to promote corporate interests (Clinard and Quinney 1973; Clinard and Yaeger 1980; Pearce and Snider 1995; Pearce and Tombs 2002; Friedrichs 2004; Passas and Goodwin 2004). Various forms of crimes and harms committed by enterprises or corporations extracting or exploiting natural resources, from fraud and tax evasion to safety violations, pollution or even murder, are widely discussed and researched by these authors and highly applicable to both cases tackled by the LAR project.

The second subcategory, 'governmental crime', is used as a blanket term for the whole range of crimes committed in a governmental context, whether by state agencies and officials on behalf of the state (state crime) or by officials and politicians for direct personal benefit (political white collar crime) (Friedrichs 2004: 116; Cohen 2001; Ermann and Lundman 2002; Green and Ward 2004). Governmental crime might be committed by individuals or organizations for economic or political gain, and includes actions defined as criminal by national or international law (e.g. genocide, war crimes, corruption, bribery, etc.), as well as 'crimes of omission', in which state negligence produces clear and severe harm. These 'crimes of omission', which might not (yet) constitute criminal offences, are particularly relevant (and prevalent) in the realm of economic, social and cultural rights violations, and, as we will further argue from a green criminological perspective, in the field of crimes and harms against nature.

Drawing on the intersections of corporate and governmental crime, a third notion in our project worth exploring is that of 'state-corporate crime' (Friedrichs 2002; Kramer, Michalowski and Kauzlarich 2002; Michalowski and Kramer 2006). Statecorporate crime is defined as "illegal or socially injurious action that occurs when one or more institutions of political governance pursue a goal in direct cooperation with one or more institutions of economic production or distribution" (Michalowski and Kramer 2006: 15). Many of the illegal practices and harmful behaviours in the exploitation of natural resources in the two regions tackled by LAR originate or manifest in the intersection between the state (officials) and mining, energy or agro-business companies.

Fourth and last, another concept to be used and applied is that of 'organized crime'. This is a far more problematic and vague concept since most forms of crimes are organized, certainly those committed by powerful actors for financial gain. Despite the hundreds of definitions and the vast literature accumulated on this matter, we feel that a critical, relational concept of organized crime can be useful to describe and analyze the connections and overlaps between illegal enterprises, groups or networks involved in the production and distribution of illegal goods of services (from mafia-like organizations to unorganized ad-hoc networks or groups), and wider legal networks and structures (state, legal economy and society) at both local and global levels (Chambliss 1989; Ruggiero 1996; 2000; Friman and Andreas 1999; Paoli 2002; Siegel et al. 2002). Illegal drugs (coca cultivation and cocaine trafficking), non-state 
violence (armed protection or response), wildlife trade, money laundering and arms trade are just a few examples of the illegal goods and services encountered in the regions studied. The violence perpetrated by 'pistoleros', paramilitary forces or some individual actors in the regions dealt with by the LAR project often has ramifications for or overlaps with some of the violence deployed by organized crime in the protection and regulation of illegal businesses such as cocaine production and trafficking.

These illegal businesses, and the actors involved in them, therefore often overlap or have close connections with political or economic actors that deal with the exploitation of natural resources in conflict regions. Moreover, it is interesting to note that illegally exploited resources (e.g. illegal timber) generally end up as legal products in the global economy, showing a parasitic or symbiotic relationship between the illegal 'underworld' and the legal 'upperworld' (Passas 2002).

Before examining the added value of green criminology to the study of conflict and natural resources, we present a final relevant contribution to expand the boundaries of criminology beyond legalistic notions of crime, the so-called 'social harm perspective' (Hillyard et al. 2004; Hillyard and Tombs 2004; Pemberton 2004; 2007). Social harm theorists actually propose abandoning the 'myth of crime' and criminology's fixation with individual notions of responsibility and intent altogether (Hillyard and Tombs 2004). In contrast, they emphasize placing 'social harm' at the center of the debate, focusing on the social origin of harm and the centrality of indifference (omission, negligence, denial) in the production of harm (Pemberton 2004). Instead of making sterile distinctions between criminal and non-criminal harms (that says very little about the seriousness of harms and a lot about differential power to criminalize behaviour), social harm theory actually makes no distinction between crimes, outcomes of the market economy, accidents, mistakes, war, disease, or any other form in which harm manifests itself. This approach has interesting policy implications, as any policy should be directed to minimizing (social) harms and suffering, both of which are always the result of various combinations of legal and illegal behaviours, mechanisms and happenings, be they intended or unintended.

Far from constituting diverging theories or paradigms, the approaches presented above all have two or three basic ideas in common: crime is socially constructed; criminalization reflects power relations; and criminology should focus on harms and not only on crimes. Moreover, they all have gradually contributed to the development of a critical criminological perspective of the crimes of the powerful. It is within this critical perspective that the expanding field of green criminology offers the most promising prospects for tackling the crimes concerning natural resource exploitation.

\subsection{GREEN CRIMINOLOGY}

Green criminology explicitly takes the concept of harm as a point of departure: harm against environments, humanity and other animals (Beirne and South 2007; White 2010). While the harm concept, as explained above, is not new to criminology, green criminology has widened the concept of victimization. As such, green criminology transcends criminology's traditional anthropocentrism to include nonhumans such as (other) animals or eco-systems within the parameters of what is considered a victim of harmful behaviour (White 2008). Green criminology usually departs from an 
eco-centric perspective, regarding humans as part of eco-systems, with human and environmental victimization strongly interconnected. Green criminologists conceive humans as both threats and potential defenders of sustainable environments, applying notions of human and environmental rights and justice.

Until recently, the plundering of the earth's natural resources has not been thought of as a crime. The earth and its resources are being wasted and overexploited, a practice in which numerous crimes, violations, unethical practices and irregularities are perpetrated against the environment. Criminologist Nigel South (2009) therefore proposed to label such acts as 'green crimes', a term he broadly defines as crimes against the environment.

An equivalent of green crime is eco-crime, or ecological crime, as Reece Walters (2006) explains in, The Sage Dictionary of Criminology. Walters's (2006: 146) definition of eco-crime encompasses "acts of environmental harm and ecological degradation," which can either be illegal and/or harmful behaviour, including threatening, damaging or destroying the natural environment. Some authors consider legal acts that are environmentally harmful, such as feeding animals with antibiotics, bio-prospecting and patenting traditional medicines and genetic material, or expanding the monocultures of agro-fuels, as part of eco-crime as well. Walters (2006) emphasizes, however, that a definitive definition of the term does not exist (yet), not uncommon in a new area of research. He concludes that green criminology is a useful paradigm for analyzing both sociological and legal definitions of eco-crime. It "provides an umbrella under which to theorise and critique the emerging terminology related to environmental harm" (Walters 2006: 147).

As a concept, environmental crime existed long before green criminology emerged in the early 1990s. Both criminological concepts certainly have some overlap, but whereas environmental crime is a traditional concept of legally defined crimes against nature, green criminology embraces the concept of social and environmental harm as its point of departure. Although some of those harms are also formally defined as crimes, with harm as its point of departure, the scope of green criminology is larger than that of environmental crime.

Piers Beirne and Nigel South have further developed the concept of green criminology in two edited volumes (South and Beirne 2006; Beirne and South 2007). Green criminology does indeed seem to be an appropriate umbrella term for the various subjects that are discussed in these books, which now form the basis of this new criminological research area. In their book, Issues in Green Criminology, Beirne and South argue that green criminology "should be a harm-based discourse that addresses violations of what some have variously termed environmental morality, environmental ethics, and animal rights“ (2007: xiv). Green criminology, they continue, "will try to uncover relevant sources and forms of power, including the state's willingness or reluctance to construct certain forms of harm as crimes, as well as social inequalities and their ill effects" (Beirne and South 2007: xiv).

In quite a number of countries, especially in the Global South, a substantial or large part of natural resource exploitation is illegal. This is true, for example, for much of the logging and some of the mining in tropical Africa, America and Asia (Boekhout van Solinge $2008 \mathrm{a}-\mathrm{c} ; 2010 \mathrm{a}-\mathrm{b})$. That a substantial part of this natural resource exploitation is illegal and thus technically a crime (and in some cases a misdemeanour), is often forgotten or not explicitly stated. 
The harm principle as it is used in green criminology (Beirne and South 2007; Sollund 2008; Kangaspunta and Marshall 2009; White 2010) applies fittingly to land-use change and land conflicts in tropical regions. In the first place, these processes cause human harm. Several communities in the areas under study are directly threatened by changing land use. They are threatened, chased away or choose to leave their communities as the forests around them disappear. Likewise, they are evicted or watch as their land is grabbed from them. This includes traditional, afro-descendent, indigenous, peasant and river populations, most of which can be found in both of the areas in which the LAR project operates.

In addition to humans, many non-humans are threatened by tropical deforestation. This is due to the fact that tropical rainforests contain more than half of the planet's biodiversity. In the words of well-known biologist Edward Wilson, who introduced the term biodiversity:

The headquarters of global diversity are the tropical rainforests. Although they cover only about six percent of the land surface, their terrestrial and aquatic habitats contain more than half of the known species and organisms. They are also the leading abattoir of extinction, shattered into fragments that are then being severely adulterated or erased one by one. (Wilson 2002: 59)

One result of this annuitization of nature is the "accelerating extinction of natural ecosystems and species" (Wilson 2002: 150). Wilson explains that the "damage already done cannot be repaired within any period of time that has meaning for the human mind," and subsequently poses the question, "Why, our descendants will ask, by needlessly extinguishing the lives of other species, did we permanently impoverish our own?" (Wilson 2002: 150).

More recently, Rob White (2011) has carefully formulated an eco-global criminological agenda that combines an orientation towards ecology and justice (eco-justice) with global studies (White 2011: 19). Environmental harm is also best seen here in terms of justice, based on notions of human or social (environmental rights and justice), ecological (ecological citizenship and justice) and animal rights (species justice), as well as egalitarian concerns (White 2011: 23). This strong link between socio-environmental harms (victims) and justice (rights) is explicit from a green criminological approach and forms one of the theoretical pillars of the LAR project. Any attempt to enhance or realize any form of environmental justice in practice (by dealing with harm created by land-use change, with issues concerning social inequality, access to territory and water, etc.) should start by recognizing and protecting economic, social, cultural and environmental rights that are violated in the process of exploiting natural resources for the benefit of few.

\subsection{THE HUMAN RIGHTS-BASED PERSPECTIVE}

In addition to a green criminological approach, a human rights-based approach is applied within the LAR project, particularly by the human rights organization FIAN International. A HRBA is founded on the conviction that each and every human being, by virtue of being human, is a holder of certain rights. By definition, human rights are universal, interdependent, indivisible and interrelated, and seek to protect human 
dignity (UN 1948). They are derived from the needs and aspirations of ordinary people. They empower each human being and their communities with entitlements and enforceable claims vis-á-vis their own and other governments. Human rights explicitly address power imbalances; at the very core of the human rights idea is the will to resist oppression (Monsalve 2012).

Stemming from the Universal Declaration of Human Rights (UN 1948), two sets of human rights have been defined and recognized at the international level. The first of these are civil and political rights (ICCPR 1966), including for example the right to self-determination, physical integrity, liberty and security, equality before the law and fair trial, political participation, and the right to not being discriminated. The second set pertains to economic, social and cultural rights (ICESCR 1966), which include labor rights, the right to social security, family life, an adequate standard of living (including the right to food, water and housing), health, free education, and to participation in cultural life. The social, economic and political processes caused by land-use change and land grabbing challenge many of these rights of local communities and individuals, if they are not already overtly violated.

The human rights framework offers a variety of standards and instruments of international law that have been agreed upon by the international community in order to guarantee and protect the rights of every human being "without distinction of any kind, such as race, colour, sex, language, religion, political or other opinion, national or social origin, property, birth or other status" (Principle of Non-Discrimination, UDHR 1948). All human rights declarations, conventions and their respective General Comments set a minimum standard for a human life in dignity. States party to these treaties have committed themselves to complying with the obligation to protect human rights in their own countries and beyond their national borders. As a consequence, the responsibility for the compliance with human rights is or is becoming a transnational and global issue, which increases with the pace of economic and financial globalization. The recently adopted, Maastricht Principles on Extraterritorial Obligations of States in the area of Economic Social and Cultural Rights (ETO Principles 2011), are a response to the urgent need to tackle human rights violations caused by transnational actors.

When conducting case studies of conflicts regarding land-use change and landproperty change in the context of the LAR project, a HRBA focuses in the first place on the relationship between the rights-holder (individual person or group), the dutybearer (state) and, in certain cases, third actors involved in the conflict (companies, etc.). It identifies violations of human rights of a victimized group and analyzes a state's compliance with its human rights obligations. Civil and political human rights (ICCPR 1966), as well as economic, social and cultural rights (ICESCR 1966), impose three different types of obligations on states: the obligations to respect, protect and fulfil.

First, the obligation to respect requires states to refrain from interfering negatively with the enjoyment of rights. Thus, the right to housing or the right to territory is violated if states engage in, for example, arbitrary forced evictions. The obligation to protect requires states to try and prevent violations of such rights by third parties. Thus, the failure to control the extraction of water by a private company may amount to a violation of the right to water and the right to food of surrounding communities that consequently lack access to drinking water or irrigation water for their crops. The obligation to fulfil requires states to take appropriate legislative, administrative, budgetary, judicial and other measures towards the full realization of such rights. 
Thus, the failure of states to provide essential primary healthcare to those in need may amount to a violation of human rights (Maastricht Guidelines 1997). We see here, as explained before when we discussed the notion of harm, that omission and negligence are clearly viewed as human rights violations.

A human rights based analysis of conflicts over natural resources, as tackled by the LAR project, shows a strong impact on economic, social, cultural and environmental rights of the affected communities, in particular rights to territory, water, food and selfdetermination (FIAN 2010). In international human rights law, several declarations and treaties explicitly protect the access to and use of natural resources as a fundamental source of livelihood. In article 1.2, The International Covenant on Economic Social and Cultural Rights states,

All peoples may, for their own ends, freely dispose of their natural wealth and resources without prejudice to any obligations arising out of international economic co-operation, based upon the principle of mutual benefit, and international law. In no case may a people be deprived of its own means of subsistence. (ICESCR 1966)

Especially in rural areas, access to natural resources and assets is directly linked to the right to an adequate standard of living as defined in article 11.1: "the States Parties to the present Covenant recognize the right of everyone to an adequate standard of living for himself and his family, including adequate food, clothing and housing, and to the continuous improvement of living conditions" (ICESCR 1966). According to this definition, a deterioration of the living conditions of a victim group beneath this minimum standard amounts to a violation of rights if the worsening is a consequence of state action or inaction (lack of control).

In the conflict areas where the LAR project is conducted, indigenous and afrodescendant communities are especially affected by land-use change. The special relation to nature and their ancestral lands is recognized and protected in several human rights documents. Both the C169 Indigenous and Tribal Peoples Convention of the International Labour Organization (ILO 1989) ${ }^{4}$ and the UN Declaration on the Rights of Indigenous Peoples (UN 2007) protect their cultures and livelihoods. They enshrine indigenous peoples' right to access and own (ancestral) land. Furthermore, they guarantee the right to Free Prior Consultation and Informed Consent (FPIC) regarding decisions concerning the governance and use of their lands and territories.

An interesting aspect of the conflicts tackled in the LAR project is that they are mainly a result of large-scale development projects such as hydroelectric dams, extraction of mineral resources and expansion of large-scale commercial agricultural production. The rights, needs and economic priorities of different stakeholders are conflicting, and the result is generally to the detriment of those less economically and politically powerful. However, human rights standards still apply for these situations in order to reduce harm. They are laid down in the UN Basic Principles and Guidelines on Development-Based Evictions and Displacement (UN 2008). ${ }^{5}$

\footnotetext{
${ }^{4}$ Twenty-two states mainly from Latin America, including Colombia and Brazil, have ratified this convention. See http://www.ilo.org/ilolex/cgi-lex/ratifce.pl?C169

${ }^{5}$ Annex 1 of the Report of the Special Rapporteur on adequate housing as a component of the right to an adequate standard of living (UN 2008).
} 
Furthermore, a set of Voluntary Guidelines drawn up by member states of the FAO in order to give guidance to states when implementing the ESC-rights, put a particular emphasis on securing access to productive resources, such as the Voluntary Guidelines on the Right to Adequate Food (FAO 2004). Another important document that should be mentioned in the framework of the LAR project is the very recent, FAO Voluntary Guidelines on Responsible Governance of Tenure of Land, Fisheries and Forests (FA0 2012).

Unfortunately, despite the existence of a large number of internationally adopted declarations, treaties and guidelines, states often fail to effectively implement these treaties in their domestic legal, institutional and administrative systems in order to protect these rights. Therefore, a HRBA puts the attention on both the right-holder and the duty-bearer. It interprets development in the sense of capacity building and empowerment. Right-holders and their representative organizations should improve the capacities and possibilities to claim and enjoy their rights. The duty-bearers (states, institutions) should improve their capacity to meet their obligations towards the rightholders. According to these development objectives, when making and implementing laws, policies or programmes, states should follow seven human rights principles: Participation, Accountability, Non-discrimination and special attention to vulnerable groups, Transparency, Human Dignity, Empowerment, and Rule of Law (PANTHER) (FAO 2006).

Within the LAR project, the HRBA contributes to the research activities by documenting and analysing concrete cases of human rights violations. It translates research findings into capacity building and development activities seeking to improve the situation of rights-holders and eventually to reduce conflict. We will now briefly describe the cases focused on by the LAR project, before discussing how the ideas, perspectives and concepts emerging from green criminology and the HRBA can have an impact on policy.

\subsection{THE COLOMBIAN CAUCA BASIN}

In Colombia, LAR is developing different sub-projects in the region of the Cauca Valley, an area that belongs to the departments of Cauca Valley and Cauca in southwest Colombia. The local governments' 2008 participative enquiry in the region showed that the most important factors causing social and environmental conflicts were: air contamination (burning), water pollution (agro-chemicals), water and soil depletion (desertification), and forced displacement due to industrial sugar cane cultivation and transnational mining activities. These conflicts around land-use change and access to land and resources are being closely followed and documented by LAR's local partners (CENSAT and PCN 2008; CENSAT 2011; Salcedo Fidalgo et al. 2012).

Since the 1990s, increased national incentives and demand for bio-ethanol attracted transnational investors. Sugar cane as a monoculture advanced into protected areas bordering the rivers and human settlements. Along with uncontrolled deforestation, the current situation threatens access to land, water, food and health, resulting in economic and forced displacement. According to the local population, the current situation is the worst in decades. In the department of Guachené, for example, more than $80 \%$ of the arable land is planted with sugar cane. 
Mining expansion for gold (by Anglo Gold Ashanti and the Canadian company Cosigo Resort) in the districts La Toma and Suárez, and possibly also in Buenos Aires and Santander, is another serious problem that is mainly suffered by the AfroColombian communities, whose rights are not respected by the mining corporations. The affected populations are predominantly Afro-Colombians that have historically been excluded from secure access to land and land tenure, and continue to be the ethnic group most affected by (forced) displacement in Colombia (Rodríguez Garavito et al. 2009).

In 2009, Colombia's Constitutional Court mentioned three factors for these conflicts: structural exclusion of Afro-Colombians, expansion of agriculture and mining, and lack of legal and institutional protection. The Constitutional Court drew special attention to the situation of the Afro communities in the municipalities of Buenos Aires and Suárez as emblematic cases. They are a clear example of conflict over territorial rights, communities' loss of social and cultural control, the violation of their right to Consultation with Free Prior and Informed Consent (FPIC), and the absence of registration of ancestral territories that even today remain unrecognized as collective property.

It is important to emphasize that these processes of land-use change involving different natural resources are interrelated through their environmental and social effects and harms. As explained earlier, these complex phenomena might not constitute criminal offences per se, but they are fertile soil for green criminologists for various reasons due to the clear and identifiable human induced social and environmental harms. First, most of the processes that take place in the area studied are accompanied by acts that involve clear criminal offences, some very serious. They include, for example, assassinations or disappearances of, and physical violence and threats against community leaders, activists and anyone who opposes top-down plans by companies or public authorities in the regions. Second, as typical forms of corporate crime, many of these processes involve the violation of administrative and civil law - for example, the systematic breach of labour, safety, environmental or business regulations. Finally, although not considered crimes, most of these mechanisms imply gross human rights violations, including ESC rights such as the rights to food, water and territory.

Examples of LAR activities in Colombia guided by a green criminological perspective include ethnographic fieldwork on access to justice for affected communities, participatory action research reconstructing the social cartography of land-use change in the Cauca Department, a study of the criminalization of environmental protest and conflict, and a comparative study of corporate crime and harms by a transnational gold mining company. Other LAR activities, such as the development of prior consultation tools or the monitoring of state compliance with ESC and indigenous rights, are guided by a human rights based approach.

\subsection{THE BRAZILIAN TAPAJÓS BASIN}

In Brazil, the LAR project focuses on the Tapajós basin in the lower Amazon, an area in the western part of the State of Pará, north Brazil. Land exploitation through mining and agriculture is driving this state's economy. Pará is also the Brazilian state in the Amazon that exports the most timber. 
Pará state has a general reputation of lawlessness. It is by far the Brazilian state where the most conflicts over land use occur (CPT 2009). A well-documented report by Greenpeace (2003) described it as a 'state of conflict'. Land grabbing, human rights violations and conflicts between communities, big landowners and (multinational) companies occur on a regular basis. High-profile murders over land-use, which attracted international attention, have taken place in western Pará. In 2005, American Sister Dorothy Stang, locally a well-known protector of the rainforest and the poor, was killed. She had repeatedly received death threats from loggers and landowners, although in the end it appears ranchers were responsible for the murder. In 2011, a prominent couple of rainforest protectors were also murdered. Their names had been on a hit list for a long time, but the two were refused police protection. This double murder was widely reported in the international press as it occurred on the very same day that the Brazilian House of Representatives voted for a new and controversial Forest Act that allows farmers and ranchers to deforest more (Phillips 2011: 27).

While these murders received considerable international attention, deforestation in the Amazon has led to numerous, mostly unknown cases of conflict, violence and murder (Boekhout van Solinge 2010a; 2010b). Before the murder on rubber tapper Chico Mendes in 1989 (which also garnered much international attention), only ten people had ever been brought to court despite the roughly 1,000 murders that occurred in the Amazon in the 1980s (Phillips 2008: 23). It is estimated that 475 activists were murdered in the state of Pará between 1996 and 2001 (London and Kelly 2007: 139). The Pastoral Land Commission CPT revealed in 2008 that at least 260 people, among them a Catholic Bishop, were living "under the threat of murder because of their fight against a coalition of logger, farmers and cattle ranchers" (Phillips 2008: 23).

In the Tapajós valley in western Pará, several conflicts can be identified: land (especially soy cultivation), water and mining conflicts. Deforestation for soy has only exacerbated the existing conflicts between forest exploiters (cattle, agriculture or mining) and forest inhabitants. The majority of the deforestation is illegal and land tenure disputes are common.

Soy cultivation has increased substantially in the area since 2003, when American soy giant Cargill constructed a soy export harbor terminal in Santarém, the location at which the clear water Tapajós river flows into the muddy Amazon river, some 800 kilometers from the Amazon river's mouth. Large landowners from the south of Brazil buy -often through corruption- or grab land. It is common for farmers to use pistoleros (gunmen), forcing traditional communities to leave (CIMI 2009).

A recently constructed bauxite mine run by the American aluminium corporation Alcoa near the town of Jurutí, also along the Amazon river, has become the subject of yet another conflict. The Federal government has approved deforestation to clear rainforest for the mine, but traditional forest communities have protested, exclaiming that their existence was not mentioned in environmental impact studies. Other conflicts are emerging in the area too, such as one over the planned hydroelectric dams in the Tapajós river.

Activities from a green criminological perspective that have been developed or supported by the LAR project in Brazil include research on the water pollution around soy fields by environmental biologists, the legal/illegal mechanisms and practices behind 
land grabbing, and development initiatives like trainings for community leaders or policy dialogues between civil society and the public prosecution office. A HRBA is reflected in research on the criminalization of environmental and human right defenders, as well as in a study of the legal framework for the exercise of ethnic and territorial rights.

\subsection{CONCLUSION}

This chapter has shown that several criminological concepts and a HRBA can be applied to the issue of conflict and natural resource exploitation. Criminological concepts, such as governmental crime, corporate crime, organized crime and combinations of these concepts, can highlight key aspects of the processes at work in the exploitation of natural resources in the LAR project's two focus areas.

From a green criminological perspective, it is not crime but harm, both social and environmental, that is the point of departure. Green criminological concepts are perfectly suited to conflicts over natural resource exploitation in a number of different ways. Social or human harm can be established by identifying the possible victims of (conflicts over) natural resource exploitation. The environmental or ecological harm can be directly assessed, for example, at the loss of (rain) forest and terrestrial or aquatic biodiversity, or at the levels of pollution. As victims are often not recognised in such a way and hardly have access to the criminal justice system, research results can contribute to local populations being acknowledged as victims of illegal or otherwise harmful natural resource exploitation. Moreover, LAR can also contribute to empowering communities by not only identifying harm, but also establishing which human rights are being violated, how communities can claim them, and how states can respect, protect and fulfil them.

When the (theoretical) concepts of green criminology and the human rights based approach are combined, it can have various policy implications and results. Reducing social harm in this case means increasing access to the criminal justice system and improving the rule of law. Improving the rule of law through increased access to the criminal justice system clearly belongs to the general objectives of the human rights approach. If both could be improved, this would fit under the headings of development and good governance. Reducing environmental harm in this case refers to reducing the environmental impact of land-use change in bio-diverse areas in South America, and stimulating less environmentally harmful and more sustainable land use that respects human rights. This is particularly true in the Brazilian case, where much rainforest is cut for timber and agriculture (mainly soy, but also cattle). This not only affects terrestrial, but aquatic biodiversity as well, as pesticides that are used in agriculture affect the water quality and water life in the Tapajós and Amazon rivers.

Increased knowledge of the phenomenon of harmful natural resource exploitation and the different players involved makes it easier to intervene (more) effectively. Although increased and more just and effective law enforcement could be an option in some cases, harm reduction and crime reduction policies should aim at limiting or removing the (legal or corporate) structures that allow and facilitate exploited resources to be traded (seemingly) legally. 
With regard to the strategies and interventions aimed at limiting crimes and neutralizing criminal organizations, criminological knowledge points to a tougher, less selective and more effective governmental presence and regulation, with a stronger rule of (just) law and more robust participation in policy development by the affected communities. Fighting corruption and collusion is obviously part of a strategy of a resilient rule of law. In the case of corporate crime, a combination of firm regulation and sanctions with an effective strategy of 'naming and shaming' (Braithwaite and Drahos 2002) can offer some hope. In more general terms, labelling certain natural resource exploitation activities or emphasizing the crimes that occur in the process, can already contribute to more awareness about the harms and crimes that are related to natural resource exploitation, and, in doing so, possibly improve the interventions by governments, corporations and NGOs to limit them.

Practically speaking, public and private policies should increase corporate responsibility and professional integrity, limit corruption, increase the rule of law, and promote all initiatives that empower the participation of affected communities in policy making. Combined with true policies of sustainable land use, interventions that help them to claim their rights, and improve their access to justice will contribute to prevent the crimes and harms related to (illegal) natural resource exploitation.

\section{REFERENCES}

Becker, H. S. 1963. Outsiders. Studies in de sociology of deviance. New York: The Free Press.

Beirne, P. and N. South (eds.). 2007. Issues in Green Criminology. Confronting harms against environments, humanity and other animals. Devon: Willan Publishing.

Boekhout van Solinge, T. 2008a. Eco-Crime: the Tropical Timber Trade. In Organized Crime. Culture, markets and policies, ed. D. Siegel and H. Nelen, 97-111. New York: Springer.

Boekhout van Solinge, T. 2008b. Crime, Conflicts and Ecology in Africa. In Global Harms. Ecological Crime and Speciesism, ed. R. Sollund, 97-111. New York: Nova.

Boekhout van Solinge, T. 2008c. The Land of the Orangutan and Bird of Paradise Under Threat. In Global Harms. Ecological Crime and Speciesism, ed. R. Sollund, 51-70. New York: Nova.

Boekhout van Solinge, T. 2010a. Equatorial Deforestation as a harmful practice and criminological issue. In Global Environmental Harm. Criminological Perspectives, ed. R. White, 20-36. Devon: Willan Publishing.

Boekhout van Solinge, T. 2010b. Deforestation crimes and conflicts in the Amazon. Critical Criminology 2010 (18) 4: 263-277.

Braithwaite, J. and P. Drahos. 2002. Zero Tolerance, Naming and Shaming: Is There a Case for it with Crimes of the Powerful? Australian and New Zealand Journal of Criminology 35, no. 3: 269-288.

Chambliss, W. 1989. State-Organized Crime. Criminology 27: 183-208.

CENSAT and Proceso de Comunidades Negras. 2008. Agrocombustibles. "Llenando tanques, vaciando territorios.” Bogotá: CENSAT

CENSAT. 2011. Agua o Minería. Un debate nacional. Bogotá: CENSAT.

CIMI Conselho Indigenista Missionário. 2009. Violência contra os povos indígenas no Brasil. Brasilia: CIMI.

Clinard, M. and R. Quinney. 1973. Criminal behavior systems: A typology. New York: Holt, Rinehart \& Winston. 
Clinard, M. and P. Yeager. 1980. Corporate Crime. New York: Free Press.

Cohen, S. 2001. States of Denial. Knowing about Atrocities and Suffering. Cambridge: Polity Press.

CPT Comissão Pastoral de Terra. 2009. Conflitos no campo Brasil 2008. Goiâna: CPT.

Ermann, M. and R. Lundman (eds.) 2002. Corporate and Governmental Deviance. Oxford: Oxford University Press.

ETO Principles. 2011. Maastricht Principles on Extraterritorial Obligations of States in the area of Economic, Social and Cultural Rights (28 September 2011). Maastricht.

FAO. 2004. Voluntary Guidelines to Support the Progressive Realization of the Right to Food in the Context of Natural Food Security. Rome: FAO.

FAO. 2006. A Primer to the Right to Adequate Food. Rome: FAO.

FAO. 2012. Voluntary Guidelines on Responsible Governance of Tenure of Land, Fisheries and Forests in the Context of National Food Security. Rome: FAO

FIAN International. 2010. Land Grabbing in Kenya and Mozambique. A Report on Two Research Missions - and a Human Rights Analysis of Land Grabbing. Heidelberg: FIAN.

Friedrichs, D. 2002. State-corporate crime in a globalized world. Myth or major challenge? In Controversies in White-Collar Crime, ed. G. Potter, 53-72. Cincinnati: Anderson Publishing.

Friedrichs, D. 2004. Trusted Criminals. White Collar Crime in Contemporary Society. Belmont: Wadsworth (4th edition).

Friman, H. R. and P. Andreas (eds.) 1999. The Illicit Global Economy \& State Power. Lanham: Rowman \& Littlefield Publishers, Inc.

Green, P. and P. Ward. 2004. State Crime. Governments, Violence and Corruption. London: Pluto Press.

Greenpeace International. 2003. State of Conflict. An Investigation into the Landgrabbers, Loggers and Lawless Frontiers in Pará State, Amazon. Amsterdam: Greenpeace International.

Hillyard, P., C. Pantazis, S. Tombs and D. Gordon (eds.). 2004. Beyond Criminology. Taking Harm Seriously. London: Pluto Press.

Hillyard, P. and S. Tombs. 2004. Beyond Criminology? In Beyond Criminology. Taking Harm Seriously, ed. P. Hillyard, C. Pantazis, S. Tombs and D. Gordon, 10-29. London: Pluto Press.

Helmkamp, J., J. Ball and K. Townsend (eds). 1996. Definitional Dilemma: Can and Should There be a Universal Definition of White Collar Crime? Morgantown: National White Collar Crime Center.

ICCPR. 1966. UN International Covenant on Civil and Political Rights (16 December 1966). New York.

ICESCR. 1966. UN International Covenant on Economic Social and Cultural Rights. (16 December 1966). New York.

ILO. 1989. C169 Indigenous and Tribal Peoples Convention (27 June 1989). Geneva.

Kangaspunta, K. and I. Haen Marshal (eds.) 2009. Eco-Crime and Justice. Essays on Environmental Crime. Turin: UNICRI.

Kramer, R., R. Michalowski and D. Kauzlarich. 2002. The Origins and Development of the Concept and Theory of State-Corporate Crime. Crime \& Delinquency 48, no. 2: 263-282.

London, M. and B. Kelly. 2007. The Last Forest: The Amazon in the Age of Globalization. New York: Random House.

Maastricht Guidelines. 1997. Maastricht Guidelines on Violations of Economic, Social and Cultural Rights. Maastricht.

Michalowski, R. and R. Kramer (eds.). 2006. State-Corporate Crime: Wrongdoing at the Intersection of Business and Government. London: Rutgers University Press.

Monsalve Suárez, S. 2012. The Human Rights Framework in Contemporary Agrarian Struggles. Journal of Peasant Studies, iFirst article: 1-52.

Paoli, L. 2002. The Paradoxes of Organized Crime. Crime, Law \& Social Change 37: 51-97. 
Passas, N. 2002. Cross-Border Crime and the Interface Between Legal and Illegal Actors. In Upperworld and Underworld in Cross-Border Crime, ed. P. van Duyne, K. von Lampe and N. Passas, 11-41. Nijmegen: Wolf Legal Publishers.

Passas, N. and Goodwin, N. (eds.). 2004. It's Legal but It Ain't Right. Harmful Social Consequences of Legal Industries. Ann Arbor: University of Michigan Press.

Pearce, F. 1976. Crimes of the Powerful. Marxism, Crime and Deviance. London: Pluto Press.

Pearce, F. and L. Snider (eds.). 1995. Corporate Crime: Contemporary Debates. Toronto: University of Toronto Press.

Pearce, F. and S. Tombs. 2002. States, Corporations, and the 'New' World Order. In Controversies in White-Collar Crime, ed. G. Potter 185-222. Cincinnati: Anderson Publishing.

Pemberton, S. 2004. A Theory of Moral Indifference: Understanding the Production of Harm by Capitalist Society. In Beyond Criminology. Taking Harm Seriously, ed. P. Hillyard, C. Pantazis, S. Tombs and D. Gordon, 67-83. London: Pluto Press.

Pemberton, S. 2007. Social Harm Future(s): Exploring the Potential of the Social Harm Approach. Crime, Law and Social Change 48, no. 1: 27-41.

Phillips, T. 2008. Hundreds of Brazil's Eco-Warriors at Risk of Assassination. The Guardian. 22 December 2008.

Phillips, T. 2011. Death in the Amazon: Brazil accused of protecting trees but not its people. The Guardian. 22 September 2011.

Rodríguez Garavito, C., T. Alfonso Sierra, and I. Cavelier Adarve. 2009. El desplazamiento Afro, tierra, violencia y derechos de las comunidades negras en Colombia. Bogotá: Ediciones Uniandes.

Ruggiero, V. 1996. Organized and Corporate Crime in Europe. Aldershot: Dartmouth.

Ruggiero, V. 2000. Crime and Markets. Essays in Anti-Criminology. Oxford: Oxford University Press.

Salcedo Fidalgo, A., I. Vélez Torres, D. Varela Corredor and S. Rátiva Gaona. 2012. Arreglos estatales, migraciones forzosas y confinamientos: cartografías históricas en la Cuenca Alta del Río Cauca. Bogotá: UNC.

Sellin, T. 1938. Culture Conflict and Crime. New York: Social Science Research Council.

Siegel, D., H. van de Bunt and D. Zaitch (eds.) 2003. Global Organized Crime. Trends and Developments. Dordrecht: Kluwer Academic Publishers.

Sollund, R. (ed.) 2008. Global Harms. Ecological Crime and Speciesism. New York: Nova.

South, N. 2009. The Greening of Criminology. In Criminology: A Sociological Introduction (2nd Edition), ed. E. Carrabine, P. Cox, M. Lee, K. Plummer and N. South, 313-330. Abingdon: Routledge.

South, N. and P. Beirne. 2006. Green Criminology. Aldershot: Ashgate.

Sutherland, E. 1940. White-Collar Criminality. American Sociological Review 5, no. 1: 1-12.

Sutherland, E. 1983. White Collar Crime: The Uncut Version. New Haven: Yale University Press.

Schwendinger, H. and J. Schwendinger. 1970. Defenders of Order or Guardians of Human Rights? Issues in Criminology 5, no. 2: 123-157.

UDHR. 1948. Universal Declaration of Human Rights adopted by the United Nations General Assembly (10 December 1948). Paris: UDHR.

United Nations 2007. Declaration on the Rights of Indigenous Peoples (13 September 2007). New York: UN.

United Nations 2008. UN Basic Principles and Guidelines on Development-Based Evictions and Displacement (Annex 1 of the Report of the Special Rapporteur on adequate housing as a component of the right to an adequate standard of living). New York: UN.

Walklate, S. 2007. Understanding Criminology. Maidenhead: Open University Press.

Walters, R. 2006. Eco-Crime. In The Sage Dictionary of Criminology (2nd Edition), ed. E. McLaughin and J. Muncie, 146-147. London: Sage. 
White, R. 2008. Crimes Against Nature. Environmental Criminology and Ecological Justice. Devon: Willan Publishing.

White, R. (ed.) 2010. Global Environmental Harm. Criminological Perspectives. Devon: Willan Publishing.

White, R. 2011. Transnational Environmental Crime. Toward an Eco-Global Criminology. Devon: Willan Publishing.

Wilson, E. 2002. The Future of Life. New York: Alfred A. Knopf. 


\title{
Property rights, nationalisation and extractive industries in Bolivia and Ecuador
}

\author{
Murat Arsel', Carlos Mena ${ }^{2}$, Lorenzo Pellegrini ${ }^{3}$ \& \\ Isabella Radhuber ${ }^{4}$
}

\begin{abstract}
Since the election of the left-leaning leaders Morales in Bolivia and Correa in Ecuador, there have been highly contested changes regarding the role of the state in the extractive industries of these countries. While the content of these changes differ and have manifested themselves over different timescales and political approaches, they fall within the context of the politically charged and equivocal rubric of 'nationalisation'. In both countries the place of extractive industries in socioeconomic development has been acknowledged as central to understanding the nature of the ongoing changes. While the existing literature has made sweeping generalisations about the character of these new regimes, this chapter aims to bring an empirically grounded analysis of the transformation of property rights structures associated with nationalisation in the extractive sectors of Bolivia and Ecuador. Focusing primarily on the minerals sector, the chapter demonstrates that there have been shifts and swings in the property rights regimes of both countries at the 'operational level'. While these changes have indeed strengthened the role of the state, hence conforming to our definition of nationalisation, the most significant changes relate to changes in property rights at the level of 'collective-choice' rights that concern the future shape of development in these two countries.
\end{abstract}

Keywords Extractive industries, nationalisation, property rights, Bolivia, Ecuador.

\section{I INTRODUCTION}

For the past decade, several Latin American nations have undergone major political and economic changes that have significantly altered their development politics and policies. Taken together, these transformations have opened up debates regarding

\footnotetext{
${ }^{1}$ Associate Professor of Environment and Development, International Institute of Social Studies, Erasmus University Rotterdam, Netherlands (Corresponding author: arsel@iss.nl).

${ }^{2}$ Professor at the School of Biological and Environmental Sciences, Universidad San Francisco de Quito, Ecuador.

${ }^{3}$ Associate Professor of Environment and Development Economics, International Institute of Social Studies, Erasmus University Rotterdam, Netherlands.

${ }^{4}$ Post-Doctoral Fellow, International Institute of Social Studies, Erasmus University Rotterdam, Netherlands and Universidad San Francisco de Quito, Ecuador.
} 
the emergence of a 'New Left' and its ability to build a post-neoliberal development strategy. This phenomenon became evident with the election of new center-left or left governments in Venezuela in 1999, in Argentina and Brazil in 2003, in Uruguay in 2005, in Bolivia in 2006, in Ecuador and Nicaragua in 2007, in Guatemala and Paraguay in 2008, in El Salvador in 2009, and with the recent election of Humala in Peru (Cameron and Hershberg 2010; Levitzky and Roberts 2011; Wehr 2011). While the heterogeneity of the ideologies and political strategies of these leaders and the ongoing nature of the changes make it difficult to effect a coherent assessment, there is an undeniably broad process of political economic realignment in the region.

As a broad characterisation, two main trends can be observed in the development policies of these nations. On the one hand, they have made poverty alleviation and delivery of basic social protection to the marginalised communities a central plank in national development planning. On the other hand, to achieve this goal, they have aspired to make the state and the office of the president significantly stronger with the stated aim of shielding domestic political and economic structures from the detrimental influence of the neoliberal policies dominating the global level. Bolivia and Ecuador are arguably the two most important manifestations of these changes, where both trends have been deeply integrated with the changing dynamics of natural resource extraction. Specifically, the 'nationalisation' of extractive industries figures prominently in these projects as a means of funding ambitious social policies aimed at reducing poverty and inequality. Furthermore, 'nationalisation' serves both as a sphere for the exercise of heightened state power and as a symbol of the re-established sovereignty for the nation. Both the Bolivian and Ecuadorian state have made claims to being 'renewed', and one of the clearest articulations of the revitalisation of these states can be observed in the changing power dynamics between the state and extractive industries.

At a scholarly and political level, these changes have attracted considerable interest. Some observers have dismissed the political and economic changes taking place in these countries as autocratic attempts at power-grabbing (Colburn and Trejos 2010). Others, coming from the left of the political spectrum, have denounced these changes as insufficient at best and functional to the continuation of the neoliberal model at worst (Webber 2010). Concrete assessments that provide evidence regarding both the extent and nature of the changes taking place in the crucial extractive sector are just beginning to emerge (see Pellegrini 2011; Grugel and Riggirozzi 2012; Molero and Paz 2012). Conspicuously absent, however, has been a discussion regarding the meaning of 'nationalisation'. Beyond scrutinizing the empirics of policy transformations, it is necessary to situate the 'left turn' and its ambition of nationalisation within a broader analytical framework of critical studies of conflict and co-operation over natural resources (Arsel and Spoor 2010; Arsel and Buscher 2012).

Before taking on this task, however, we must first answer a seemingly simple empirical question: What exactly is the subject of inquiry when we speak about 'nationalisation'? As we have demonstrated elsewhere (Pellegrini and Dasgupta, 2011; Arsel 2012; Arsel and Angel 2012; Pellegrini 2012; Radhuber 2012), the discourse of nationalisation (and its rhetorical handmaiden, 'sovereignty') has come with sweeping constitutional, legal, social and political changes. In this chapter we focus primarily on property rights, which lie at the heart of what nationalisation is usually understood to entail. While it is difficult to differentiate the if, how and why of nationalisation, due in large part to the fact that the goals, means and outcomes of such a profoundly 
political process are fundamentally intertwined, our main focus is to lay an empirically informed groundwork for understanding exactly which changes have taken place under the rubric of nationalisation. By focusing on property rights, the chapter therefore takes an analytical step backwards from the prevailing debates on nationalisation, its relationship with populism or its role in setting a new path to post-neoliberal development policies. Building on this observation, the aim of this study is to analyse the changes taking place in Bolivia and Ecuador by focusing on the changing property rights structures concerning minerals. We do so by scrutinizing crucial aspects of relevant laws and regulations in terms of the changing role of the state and its relationship with society and nature.

The next section of the chapter provides a brief overview of the Left Turn in Latin America, highlighting the nature and significance of the changes taking place in Bolivia and Ecuador. The chapter then turns to a discussion of nationalisation and property rights, introducing Ostrom and Schlager's (1992) analytical framework, which forms the basis of the two empirically-grounded sections on the changes taking place in Bolivia and Ecuador. The concluding section returns to the question asked on the previous page (what is 'nationalisation'?) and presents a set of reflections on how to theorise nationalisation in the context of the Left Turn in Bolivia and Ecuador.

\subsection{THE LEFT TURN IN LATIN AMERICA}

The turn to the left that marked Latin American politics in the last decade comprises political changes in a number of countries including Argentina, Bolivia, Brazil, Chile, Ecuador, Guatemala, Nicaragua, Paraguay, Peru, El Salvador, Uruguay and Venezuela. By its nature, this turn includes a diverse range of countries and political positions; consequently the meaning of this political shift is vague and this diversity has been articulated in different ways. In this sense, administrations have been divided into populist or social democratic (e.g. Castañeda 2006; cf. Cameron 2009), and a rich body of literature has developed on the significance of the turn (e.g. Meschkat 2008; Cameron and Hershberg 2010; Latin American Perspectives May 2010; Latin American Perspectives July 2010; Burchardt and Wehr 2011; Escobar 2011; Levitzky and Roberts 2011). Here we focus on developments concerning Bolivia and Ecuador, two countries whose social movements have had a crucial influence on the domestic political agenda in the past decade, not only at the societal but also at the state level. These developments have seen both countries taking a plurinational character. In this sense, the administrations of the two countries to some extent incorporated social demands and have set themselves on paths to a radical rethinking of the means and goals of development. Accompanying this ongoing process of reflection are changes to indigenous people's rights and new - often profoundly different - proposals in terms of nature and natural resources management. As a result, these two countries are often considered to be proponents of alternative development models, articulated and enshrined in various policies and legal instruments, which are to be critically scrutinised by empirical research and analysis (e.g. Lang and Mokrani 2012).

Bolivia offers a fertile ground for analysis, because the country has undergone deep transformations especially after the intensified mobilisation of the social movements 
since 2000 which set a new political agenda. The country was traditionally ruled by a conservative establishment and was marked by political instability. The ascendency of the political group 'Movement Towards Socialism' (Movimiento al Socialismo, MAS) with Evo Morales, coming from the indigenous-peasant population - marked a turning point. The MAS - as the name already suggests - is not a traditional political party, but rather a political movement. Its leader, Evo Morales first became known as a trade union leader for coca farmers opposing neoliberal policies and US-sponsored antidrug policies, rather than through electoral politics. The election of Morales and the subsequent changes to the Bolivian state have been hailed as revolutionary by some (Dunkerley 2007), including the government, which gave its policies and initiatives titles such as the 'agrarian revolution', the 'ethical revolution' and the 'educational revolution' (Bolivia. Ministerio de Desarrollo Rural, Agropecuario y Medio Ambiente, 2007). Before becoming Vice-President, Alvaro García Linera argued that the social conditions in Bolivia were not ripe for socialism. Post-election, however, García Linera instead set the development of a 'Andean-Amazonian Capitalism' that could be the basis for a transformation toward socialism in the medium-long term as the primary objective of his government (García Linera 2008). Lately, he has adopted a different discourse that establishes communitarian socialism as the goal of the political process (García Linera 2010). From this point of view, the government's project is going through a phase where a stronger state is transferring resources from the private sector to communitarian organisations.

Ecuador similarly makes for a highly relevant location to observe the actual impact of the Latin American Left Turn. During his first inauguration ceremony in January 2007, the newly elected president, Rafael Correa, called for 21st century socialism that aimed at 'leaving the night of neo-liberal policies behind'. Since then, Correa has enjoyed unprecedented popularity and was re-elected by a landslide in the April 2009 elections. Reconfigurations of nature-society relationships have been portrayed as both the means and ends of the 'Citizens' Revolution' launched by Correa and his political vehicle, the Alianza PAIS. Since assuming power, the Correa government has forced several foreign owned oil companies to leave Ecuador, made changes to the constitution introducing the 'rights of nature', opened up the possibility of extensive mineral extraction (primarily of gold and copper), and made an international proposal to abandon oil extraction in the ecologically significant Yasuni National Park in exchange for approximately US\$3.5 billion. Referring to the dramatic (and often contradictory) political events taking place throughout Latin America, Arturo Escobar asserted that "Latin America is the only region in the world where some counter-hegemonic processes of importance might be taking place at the level of the State at present" (Escobar 2011: 1).

In this context, Bolivia and Ecuador have both been undergoing a highly contested nationalisation process of their extractive industries, and this process cannot be understood simply as a state takeover of private enterprises. It is more accurately described as the increased presence of the state in extractive processes, a presence that can manifest itself in numerous ways, and at different stages and scales. This increased role of the state is concomitant with the recognition and the implementation of new and old rights related to nature, as well as the use and governance of natural resources, including land. In both countries, the overall management of natural resources and the nature-society interactions are now claimed to be oriented towards the achievement of 
the concept of 'buen vivir' (in Ecuador) and 'vivir bien' (in Bolivia), as opposed to the achievement of ever-growing levels of economic wealth (Esteva 2009). These concepts are drawn from Latin American indigenous cosmologies and can be considered the strongest challenge to the Western conceptions of well-being and development that have been articulated in recent years.

\subsection{NATIONALISATION AND PROPERTY RIGHTS}

In the context of Bolivia and Ecuador, nationalisation is a politically-charged concept. While its detractors use it pejoratively to characterise any extension of state activity that interferes with the perceived sanctity of private property rights, its proponents see it as a step towards the achievement of the twin goals of socialism and sovereignty. The diverse use of the word nationalisation creates tensions and challenges around the 'real' meaning of nationalisation and one can easily find references to attempts at nationalisation being 'false' or 'incomplete'.

In this chapter, we study nationalisation by focusing on property rights. After all, the nature of property rights is key to identifying the type of political economic system that prevails in a particular setting. We define nationalisation as a policy measure that increases the sphere of action of the state, ranging from complete take-over of a company or a sector without compensation to the establishment of regulatory powers and/or increases of taxes and royalties by the state. This definition differs from some of the stricter conceptualisation of nationalisation found in earlier literature. Francioni, for example, defines nationalisation as "the compulsory transfer to the State, by virtue of legislative or executive act of a general and impersonal character, of private property or activities" (Francioni 1975: 256). The choice of a quote from nearly three decades ago is not coincidental: little attention has been paid to the concept of nationalisation and its varieties in the recent scholarly literature. This absence can perhaps be attributed to the dominance of the neoliberal doctrine, which has of course emphasised 'privatisation' and much of the recent discussion in academia has therefore focused on this type of property relationship. In this chapter, we build on existing understandings of nationalisation that focus on property rights but reject a binary distinction of the ownership of productive resources by the state or private interests. In other words, the focus is not at a technical level of 'who owns what', though that is certainly part of the overall picture. Instead, the approach adapted here is one that scrutinises the political economy of property relations, because it is through these relations - and the ways in which they are being transformed - that we can apprehend the significance of the ongoing changes in Latin America. Furthermore, by focusing on the emerging property structures that are created by nationalisation processes, we go beyond stale discussions of whether nationalisation has taken place or not. Instead, we contribute to a re-emerging discussion of what nationalisation - both in promise and deed seeks to accomplish, what (perhaps unexpected) shapes it takes and whose interests it ultimately serves.

The complexity of - and diatribes over - the concept of nationalisation are intertwined with the multifaceted nature of property and property rights. In fact, the understanding of nationalisation as an extension of state rights over certain properties immediately raises the question of which rights are changing hands. Here we 
Table 7.I Framework for the interpretation of property rights.

\begin{tabular}{ll}
\hline Rights & Description \\
\hline Access and & Right to physically access the geographical space occupied by the resource \\
withdrawal & and to extract portions of the resource. \\
Management & Right to decide how the resource is going to be accessed and exploited. \\
Exclusion & Right to put limits on the actors who access, withdraw and manage the resource. \\
Alienation & Right to transfer property rights to new holders-through donation, sale, bequest.
\end{tabular}

Source: adapted from Schlager and Ostrom, 1992

introduce a property rights theory developed by the institutional and neo-institutional economics school of thought (e.g. Demsetz 1967; Ostrom 1990) as the theoretical framework for the analysis of policy changes associated with the nationalisation of minerals in Bolivia and Ecuador. In particular, we look at the multiplicity of rights that can be exercised vis-a-vis property. We follow the categorisation of Schlager and Ostrom (1992) and divide property rights into rights to access and withdraw, manage, exclude, and alienate (see Table 7.1).

Access and withdrawal rights refer to the privilege of physically entering the geographical space of the resource, and to the extraction and appropriation of portions of the resource. The management rights refer to the ability to decide how access and withdrawal are exercised. Exclusion rights refer to the faculty of deciding who can exercise rights on the resource. Alienation rights refer to the right of transferring the property rights to new holders. These transfers can happen via donation, sale or bequest.

When taken together, Schlager and Ostrom (1992), consider the aforementioned rights as 'operational'. In doing so, they refer to the ability to exercise a particular right and differentiate from 'collective-choice' rights, which entail the ability to discuss and shape the definition of future rights. As such, collective-choice level rights are broader and go beyond the technical exercise of enforcing a set of rules. By virtue of their longer-term and open-ended nature, collective-choice level rights have far-reaching implications for shaping not only the means of using a particular property, but also the ends that are expected to emerge. In other words, the exercise of collective-choice rights not only deal with how development should take place, but also the direction and nature of development. In the following section, the nationalisation processes taking place in Bolivia and Ecuador are explored through the framework presented here. While the process of nationalisation has been very complex and is riddled with intentionally-created ambiguities in legislation, the section aims to present a linear narrative to render them suitable for evaluation through this analytical lens.

\subsection{BOLIVIA}

Bolivia has rich mineral resources and a long history of extraction and export. It has gone through various cycles of privatisation and nationalisation. The most recent privatisation process culminated in the law of 1997 . Though no generalized nationalisation process took place, subsequent actions have swung the pendulum slightly back 
towards a strengthening of the state. The three major adjustments to the 1997 law that lead to this shift are the decision of the Constitutional Court 0032/2006, the Supreme Decree No 29117, 2007 and the Constitution of 2009.

\subsection{Background}

The Bolivian economy has long been based on the exports of natural resources with various cycles in which different resources - e.g. silver, tin, natural gas, rubber, etc. - have played an important role. This dependence characterises Bolivia as a peripheral state in the capitalist world-system (Wallerstein 2007: 28f.), which is distinguished by highly unequal trade relations. Most added-value emerges in the postextraction phases of refinement, commercialisation and further use, in which most resource-rich countries do not participate (Almaráz 2010: 57). Hence, countries like Bolivia do not succeed in their aspirations of mineral-led development (Allgäuer et al. 2005: 5).

Nationalisation of natural resources and its extraction is not something new to Bolivia. In 1937, Standard Oil was expropriated and the state-owned Yacimientos Petrolíferos Fiscales Bolivianos (YPFB) was created in order to manage the hydrocarbon sector. These measures mark the beginning of the nationalisation process, which culminated in the nationalisation of the tin sector and the creation of the state-owned mining company, Corporación Minera de Bolivia (COMIBOL) in 1952 (Tahbub 2008: 21f.). During the sixties, the pendulum swung towards a short period of liberalisation, marked by an influx of private foreign investment in the mining and hydrocarbon sector. However, the liberalisation process was again interrupted by the nationalisation of Gulf Oil in October 1969 (Wanderley et al. 2010).

The last privatisation period in the 1980s and 1990s was vital for the emergence of the new protest movements that surfaced in 2000 and the subsequent nationalisation processes. This privatisation period in Bolivia also affected the mining sector, and began prior to the so-called 'stabilisation programs' enforced by international mechanisms during the dictatorship of Hugo Banzer Suárez (1971-1978) and the respective changes in the hydrocarbon laws. However, the privatisation measures only hit their peak in 1996. This was exactly ten years after the violent suppression of the miners in the Marcha por la Vida (March for Life) in 1986, when approximately 30.000 demonstrators protested the massive dismissals of miners and the minimisation of the state mining sector. Additionally, the privatisation of the hydrocarbon sector in 1996 was a highly socially contested affair despite its implementation. From then on, the state only administered concessions. A few weeks after this privatisation, the new hydrocarbon law was enacted (Gandarillas 2008: 61f.).

The pendulum swung back towards nationalisation again ten years later, when the hydrocarbon sector was formally nationalised between 2005 and 2007. No nationalisation took place in the mining sector specifically, but the state's role was strengthened by a series of policy measures. Whereas the monetary contribution of the mining sector to the Bolivian state was marginal during the privatisation period, it is currently a strategic source of income, notwithstanding the dependency on international markets and cyclical tendencies (Wanderley et al. 2010). The rising importance of the mining sector for the Bolivian economy is evinced by data from the export sector. This data shows that between 2001 to 2004 the exports from the manufacturing sector 
constituted the largest share of exports, with USD 697 million out of a total value of USD 1.226 billion in 2001 (the contribution of the mining sector was USD 189 million and the hydrocarbon sector USD 287 million). By 2010, hydrocarbon had become the largest contributor to exports, with USD 2.942 billion out of USD 6.871 billion (the share of mining was USD 1.852 billion and manufacturing USD 1.779) (Bolivia Presidency of the Republic. Mensaje e Informe 2010). While the annual contribution of the mining sector to the state coffers was only USD 11 million between 1985 and 2005, these incomes are estimated around USD 230 million annually between 2006 and 2008 (García Linera 2008: 11f.).

\subsubsection{The current legal mining regime}

Bolivian government officials have been announcing a new mining law since the enactment of the Constitution of 2009. The Constitution states that current concessions would expire and new contracts must be established within one year of the election of the Executive and Legislative, both of which took place in December 2009 (Bolivia. Constitution 2009. “Transitional Provisions," Eighth, III). Accordingly, the government announced that it aims to make adjustments in the sector, confirming the state as the owner of natural resources and amending the tax and royalties system. Various government officials further declared that this new law, which has yet to be submitted to parliament, will oblige all companies in the sector to shift to new contracts, eliminate private concessions, revert all territories that do not fulfil the socio-economic function to the state, and distribute royalties to the communities where extraction is taking place (FmBolivia 2010).

The Ministry of Labour made further details available in 2011: the new mining law would reestablish the state-owned mining company COMIBOL and consolidate five decentralised state companies: the Empresa Boliviana de Recursos Evaporíticos, the Empresa Minera Huanuni, the Empresa Boliviana de Oro y Piedras Preciosas, the Empresa Metalúrgica Vinto and the Empresa Metalúrgica Karachipampa. The control over the benefits, however, would remain in the hands of the national mining company in order to reinvest them. Finally, by privileging prospection and exploration, the mining frontier would be intentionally expanded (Página Siete 2011). However, the new mining law has yet to be made public.

As a result, the latest mining law, known as the Mining Code, dates back to 1997. The Constitution from 2009 is the most recent legal framework on mining that can currently be analysed. There are a number of other frameworks that must also be considered: Supreme Decree 28901 of 2006, which renationalised the mining company Huanuni; Supreme Decree 29117 of 2007, which declared the entire national territory as federal mining reserve; Supreme Decree No 29459 of 2008, which defines the mining company Huanuni as a national public and strategic company; and Supreme Decree No 861 of 2011, which approved an increase of the miners' salaries in Huanuni. Even though they are not equally situated in the legal hierarchy, all of these legal initiatives have had a significant political impact. In the following section, the mining law from 1997 shall be compared to the Supreme Decrees from 2006 and onwards, as well as the Constitution from 2009. Special emphasis will be placed on the ownership and the role of the state. 


\subsubsection{A comparative analysis of legislations and legal decisions}

The Mining Code of 1997 is based on the liberal model of the Supreme Decree 21060 of 1985. The decree not only eliminated the smelting monopoly and installed free trade and exports of minerals, but also liberalised prices and labour recruitment (OBIE 2008: 3). In 1986, the Supreme Decree 21298 further eliminated the federal mining areas that extended to almost $80 \%$ of the entire Bolivian territory, which were supposed to be exploited by the Corporación Minera de Bolivia (COMIBOL). Hence a significant reduction of the size of COMIBOL began to take place, and during the early $1990 \mathrm{~s}$ COMIBOL was limited to the administration of joint venture contracts. In 1993, all properties of COMIBOL were tendered and its concessions were assigned to the private sector. As a result, the state-driven mining activity was reduced to a minimum and the period of mining concessions began (OBIE 2008: 3).

\subsubsection{Mines, ownership and the role of the state}

The Mining Code of 1997, which established the concession regime, defines the original domain of the State as all minerals in their natural state, regardless of origin and form, whether under or above ground. The code positions the state as the direct and sole owner of all minerals that exist within the Bolivian territory, with the exclusive faculty of alienation. Through alienation, the state sells or leases the right of management, exclusion, or both. Hence the state still enjoys the rights of alienation, but no longer retains control over the rights of access and withdrawal, management, and exclusion (Bolivia. Ministerio de Minería y Metalurgia. Código de Minería, 1997: Art. 1).

According to the law, the State, through the Executive, will grant mining concessions to individual or collective entities, national or foreign, that request these from the Superintendent of Mines (Bolivia. Ministerio de Minería y Metalurgia. Código de Minería, 1997: Art. 2). Article 4 defines mining concession as a property right different from the ownership of the land on which it is constituted. Furthermore, it is a property that can be transferred by inheritance. According to the present law, it can be drawn on mortgage and be subject to any type of contract. Article 10 entitles the mining concession's holder to the real and exclusive right for an indefinite period to the prospecting, exploring, extracting, concentrating, smelting, refining and marketing of all mineral substances that are within the territory, including clearing, slag, tailings and mine waste, or any other metal under the condition of the payment of dues.

According to these articles, the state formally sells or leases only the right of management, exclusion, or both, and thus property rights. However, it is possible to argue that due to the extension of these exclusive property rights, the Code actually provides the concession holder the title of owner of the concession parcel and all the minerals it contains. This right is guaranteed indefinitely as long as the dues are paid in accordance with the law. This means that the state holds full de jure ownership of all minerals within the country until it grants a mining concession, after which the holder of the concession obtains the de facto ownership of the resource and also the proportional capacity of fiscal capturing.

After almost 10 years of legal validity, the Mining Code of 1997 underwent three major adjustments that redefined the type of management for the mining sector. As part 
of the policy measures to increase the state's participation in hydrocarbon and mining production, the adjustment of the Mining Code moved the legislation away from neoliberal precepts towards being more state-centered. Nevertheless, the regimes of these natural resources significantly differ, mainly because a formal nationalisation process took place in the hydrocarbon sector, while only a slight shift towards an increased state participation took place in the mineral sector.

In 2006, the sentence of the Constitutional Court Act no. 0032, 2006 determined that several articles of the Mining Code were unconstitutional as they were contrary to the Bolivian Constitution of 1967 (reformed numerous times). This constitutes the first significant adjustment. The mining legislation essentially recognised the mining concession as a private property right in favor of the holder: the holder could have indefinite ownership over the concession and register it as a credit guarantee, as well as transmit the concession by inheritance. The sentence of the Constitutional Court, however, declared this provision void as it contravenes the Constitution. Hence, the sentence of the Constitutional Court strengthened the state's proprietor rights over the subsoil and all of its content. The sentence indicated that the state was not allowed to grant ownership of the subsoil by way of mining concessions (Moreno Baldivieso 2010). Additionally, the mining company Huanuni was reintegrated into the national mining company COMIBOL in 2006, leading to a violent conflict in October of the same year between the cooperative workers and the workers assimilated by the state company $^{5}$ (Bolivia. Decreto Supremo 28901, 2006).

The second adjustment that significantly modified mining legislation came in 2007 with Supreme Decree No 29117. One year after the Sentence of the Constitutional Court, this Supreme Decree declared the entire national territory as a federal mining reserve, including metallic, non-metallic, precious stones, semi-precious stones, and brines mineralogical resources. In the exercise of its right of ownership of the federal mining reserve, the State was now capable of granting COMIBOL the jurisdiction and authority for exploitation and management, with the exception of the pre-established rights on mining areas granted previously in concession and those under the jurisdiction of municipalities. As a consequence of this decree, granting of new mining concessions was prohibited. Instead of granting concessions, the state proposed a mining regime of shared production contracts and leases (Moreno Baldivieso 2010). The Supreme Decree No 29459 of 2008 then defines the mining company Huanuni as a national public and strategic company. Furthermore, the Supreme Decree No 861 of 2011 approved an increase of the miners' salaries in Huanuni, aiming to prevent the violent conflict that took place in 2006 (Bolivia. Decreto Supremo 29459, 2008).

The third adjustment is of a more fundamental nature than the previous two, and it refers to the further adjustments made through the Constitution of 2009. The latter establishes that all natural resources, including hydrocarbons and minerals, are under the direct, indivisible and perpetual ownership of the Bolivian population. The state, on behalf of the Bolivian people, is in charge of their administration. However, the Constitution recognises the participation of private operators in different stages of the productive chain of the mining sector. This participation should no longer take

\footnotetext{
${ }^{5}$ This was followed by the approval of Supreme Decree 29025 from 2007, which should be valid for only 6 months and declared Huanuni as an emergency zone which should lead to special political measures (Decreto Supremo 29025, 2007).
} 
place though concessions, but instead through the granting of mining rights or mining contracts. In addition, it establishes that the granted mining contracts cannot be transferred, are indivisible, and are not transferable by hereditary succession (Claure Veizaga 2010). From these provisions, one can conclude that within the framework of the 2009 Constitution, the holder of a mining contract is an authorised user with the rights of access and withdrawal, as conceptualised by Schlager and Ostrom (1992).

Article 369 of the 2009 Constitution states that the state is responsible for all minerals in the soil and subsoil, independent of their origin. The groups of nationalised miners, their industrial plants and complexes, and their smelteries belong to the patrimony of the people; they cannot be transferred or ascribed to property of private companies (ibidem: Art. 372).

In summary, whereas the Mining Code from 1997 defined the state's rights of alienation, but not the rights of management, exclusion, and access and withdrawal, three major adjustments have since redefined the type of management for the mining sector towards a more state-centered regime, re-strengthening the state's proprietor rights of the subsoil and all of its content. First, the sentence of the Constitutional Court Act no. 0032, 2006 prohibited the sale and transfer of ownership by concessions. Second, the Supreme Decree No 29117 of 2007 declared the entire national territory as a federal mining reserve and eliminated the regime of concessions, proposing a mining regime of shared production contracts and leases. Third and finally, the framework of the 2009 Constitution defined the ownership of all subsoil resources as that of the people, and the holder of a mining contract only as an authorised user with the rights of access and withdrawal in accordance with Schlager and Ostrom's framework.

These adjustments in the mining regulation and in the property rights regime evince a shift from a more liberal to a more state-centered model, though this shift is much slighter than in the hydrocarbon sector where formal nationalisation took pace. The shift was made possible by the context of intense social and political contentions and mobilisations, related to natural resources in general, and the strong demand articulated in social mobilisations to establish national sovereignty over strategic natural resources. Social and especially indigenous movements demanded further societal and state rights over the natural resources as part of a specific political project. This shift was finally possible as part of the socially demanded democratisation process towards a plurinational state.

\subsection{ECUADOR}

Modern mining has a much briefer history in the Ecuadorian context. Most of the extraction in recent decades has been carried out by small, often informal entities operating with varying degrees of legality. Following the World Bank's policy advice Ecuador joined the other Latin American countries in reforming their mining codes in order to encourage foreign investment in the sector in August of 2000 (De Echave 2007). The principal objective of the new approach was to make the mining sector more attractive for multinational companies seeking to explore and exploit mineral resources. To that effect, the mining law included a number of provisions to relax regulation and reduce taxation (De Echave 2007). 
According to Carlos Espinosa, President of the Ecuadorian Chamber of Mines, representing pro-mining economic concerns, the mining law of the 2000s was a progressive law that benefitted the country in two ways: the abolition of royalties curtailed corruption by default, and international investment would come to the country (Santacruz 2007). Others, however, argue that the law was too permissive, that it undermined indigenous people's rights, and that it would engender conflict (Ortiz 2011). In fact, few constraints for companies were enforced by self-regulatory systems without any penalties for non-compliance (De Echave 2007). Indeed, the World Bank reviewed the cases of mining in Peru, Tanzania and Indonesia (where regulations were remarkably similar to the ones in Ecuador) and concluded that, "In spite of the World Bank's efforts to improve the social and environmental performance of extractive sectors, the expansion of these sectors within structural reform programs has resulted in unnecessarily high social and environmental costs, and in some cases, the exacerbation of macroeconomic vulnerabilities" (2010: 5).

\subsection{A comparative analysis of the 2000 and 2009 mining acts}

In this section we provide a comparison of the mining acts of 2000 and 2009, together with the provisions on mining contained in the new Constitution enacted in 2008 . We will start by describing the legislation approved in 2000 and then contrast it with the changes that have occurred since 2006.

The mining law of 2000 eliminated all existing royalties on extracted values, and mining companies started to pay for licenses according to the number of years they held concessions and the number of hectares in the concession. Apart from the simplicity of the rule and its attractiveness for investors, the rationale of this measure was to avoid collusion between the mining companies and state officials in charge of estimating the value of extracted resources. In addition, concessions were afforded an extension for up to 30 years, but were eligible for renewal. Taken together, these provisions meant that mining concerns could operate in the country for long periods of time and that the Ecuadorian government would only receive minimal revenues from these activities (Varela 2010). Furthermore, when the Correa administration initiated a study on the state of concessions in 2007, a preliminary report showed that this mining law had allowed for concessions to be granted very liberally, even within national parks. As a result, nearly 4,000 mining concessions were under investigation (Arteaga and Jijón 2007).

A major breakthrough in this situation came with the approval of the new constitution in 2008. The new Constitution explicitly states that strategic sectors, including non-renewable natural resources, especially mineral resources, are under exclusive state control and management. The National Plan for Mining Development 20112015 (Ecuador. Plan Nacional de Desarrollo del Sector Minero 2011-2015), a plan operationalizing the constitutional provisions in the mining sector, establishes the importance of its role by stating that its purpose is to make the mining sector more important in the economy, contemplating clear procedures to promote exploration and exploitation (Plan Nacional 2011: 43).

Despite his anti-neoliberal and anti-multinational domination rhetoric, the Correa administration remained wayward about its stance on mining from the beginning. In fact, when Correa took office in 2006, mining stock prices of companies operating 
in Ecuador dropped and fear of "nationalisation" of extractive industries potentially associated with expropriation of property was widespread (Santacruz 2007). By 2008, after years of mixed signals and ambiguous statements, it became clear that the Correa administration was interested in mining exploitation and welcomed foreign corporations for large-scale mining exploitation (e.g. Denvir 2008; Denvir and Riofrancos 2008). The Ministry of Mines and Petroleum (MMP), under Galo Chiriboga's leadership, complied with the Assembly's mandate to draft a new mining law that would attract large-scale investment and guarantee substantial state revenues at the same time. Among its highlights were: openness to large-scale and open-pit mining; establishing the state as the main actor in charge of carrying out Corporate Social Responsibility projects; royalties ranging between $5 \%$ and $8 \%$ depending on the size, investment and value of reserves of the concession; and the switch from a "mining title" to an "exploration contract" for companies. The provision for a Windfall Tax envisions charges for as much as $70 \%$ of profits (Santacruz, August 15 2008). In spite of opposition from social movements, the new mining law was finally approved on January 14th, 2009, with an overwhelming majority of 50 to 15 in the National Assembly.

\subsubsection{Mines and ownership}

In terms of the domain of the state over mines and deposits, the mining acts of 2000 as well as 2009 begin by establishing that the Ecuadorian state is the owner of all mineral wealth in the country. Despite this shared provision, the two laws contain several differences that emerge from the perspective of property rights theory by means of looking in detail at the entitlement of specific rights. These legal provisions stipulate that collective-choice level decisions are in the hands of the state. At the operational level, however, several bundles of rights are transferred to the private sector. Mining titleholders do not participate in any of the decision-making processes for management of their concessions, such as the organisation and granting of permits and concessions. Instead, the state is in charge of this process based on applications and a tendering process. Thus, titleholders may not decide who gets to participate or not on a tender, who has access to mining activities, or who has rights of access and withdrawal of substances. Similarly, the state has the authority to request certain management and exclusion provisions, such as labour. Under both mining acts, $80 \%$ of a company's workforce must be comprised of Ecuadorian employees. In the 2009 mining act, on the other hand, artisanal mining is strictly regulated with a chapter for "special regimes" dedicated to stipulate its rules. To begin with, the 2009 law provides a clear, legal definition for what constitutes artisanal mining: mining that is carried out through individual, family or associative work, with the sole purpose of being used as a means of subsistence. In addition, access to mining for artisanal purposes is restricted to specific areas designated by the state, and an application process and requirements have been established in order for the Ministry to grant artisanal miners permits to conduct their work. Importantly, one of the special restrictions imposed on artisanal mining is that no foreign capital can finance its operation. Failure to comply with these rules means that citizens would be engaging in illegal mining, and specific penalties are accordingly stipulated. These regulations amount to the establishment of exclusion rights in terms of restricting both the geographical areas and the individuals that can become artisanal miners. Furthermore, in both mining acts discussed here, the laws 
allow the state to authorise the exploitation of mineral resources to natural or legal persons, whether local or foreign, by granting them mineral rights and duties. These legal provisions essentially transfer access and withdrawal rights.

In spite of the similarities between both mining laws, one major point of departure between the two legal instruments relates to the power and scope of the state's role in the extractive industry. In the 2009 law, the state essentially acquires a more prominent role and has an enlarged oversight of the sector. With that goal in mind, the 2009 mining act also established a series of regulations aimed at restructuring the bodies governing and overseeing mining. Thus, the Ministry of Non-Renewable Natural Resources was established and separate entities to direct and regulate mining and oil affairs were also created: the Agency for Mining Control and Regulation, the National Institute for Geological, Mining and Metallurgic Research and the National Mining Company (known as ENAMI for its Spanish acronym).

\subsubsection{Mining and land ownership issues}

One of the most important property rights granted to all parties participating in mining activities under the Mining Acts of 2000 and 2009 is that, as concession titleholders, their rights of ownership are distinct and independent from the ownership of land on which the concession is located, even if both belong to the same person. This is an especially sensitive issue, because many of the mineral concessions of interest are located in areas settled by indigenous communities. This is for example the case for Intag in the Northern Highlands, as well as Zamora Chinchipe in the Southern Amazon, where Shuar Indigenous communities reside. In terms of the property rights framework, where rights correspond to duties, these regimes have essentially established a series of limits to the property rights over territories by indigenous people and farmers, who now have de facto duties to respect mining rights superimposed on their lands.

On the other hand, both the 1998 and 2006 Constitutions, as well as the Mining Acts of 2000 and 2009, contain laws and regulations for the protection of indigenous people's rights, which includes the right to their ancestral land. For example, both Constitutions ratify the ILO Convention 169 on the right to prior and informed consent. Likewise, in Article 57 of the current constitution, Indigenous people's communities and nationalities are recognised, and collective rights in order to conserve their land are guaranteed. Furthermore, the constitution declares indigenous peoples' lands as "inalienable and indivisible" and establishes that indigenous groups may not be displaced.

The Mining Act of 2009 does include a chapter dealing with "Social Management and Community Participation" to address mechanisms for citizens' right to information and consultation that apply to all communities affected by mining, independent of ethnicity. In fact, the law names the State as the responsible actor for providing information and arranging the necessary processes for participation and consultation. Article 90 calls for the compulsory consultation of communities and nationalities that may be affected by mining activities, and Article 91 names the Ministry of the Environment as the entity responsible for managing any complaints for social, cultural or environmental damages derived from mining activities.

In spite of these advances, Article 87 of the current mining law also stipulates that, "In the event that a consultation process results in the majority of opposition 
from the respective community, the decision to develop the project will be adopted by resolution of the Sectorial Ministry." Thus, although communities that may be affected by mining have the right to be informed and consulted, their opposition to a project does not necessarily result in a legally recognised resolution or action. Ultimately, local people still do not have the power to decide whether mining extraction can take place in their territory or not.

The new law further contradicts some of the provisions of the constitution and the international agreements mentioned above. The mining rights include the freedom of prospecting, but the rights to informed consultation only begin at the stage when a concession is already granted. In practice, a community can only oppose a project at a very late stage and the State has the ultimate power to decide whether a mining project takes place or not. Moreover, if the land ownership and mine ownership (or title) are distinct and independent of each other, this means that when easements are established, the lands in question are divisible, even if they are communal lands of Indigenous peoples going against their Constitutional rights. Thus, taken together, these laws suggest that the scenario for communities is more likely to be one in which companies are allowed to begin mining in their territory at any time and if they do not agree with these activities, they are not entitled to prevent it.

\subsection{TOWARDS A THEORY OF NATIONALISATION AND CONFLICT IN BOLIVIA AND ECUADOR}

Emerging from the above narratives of 'nationalisation' in Bolivia and Ecuador are several insights into the way these processes need to be theorised. It is important to ask where the 'nation' lies within the concept of 'nationalisation' and what implications the construction of plurinational states have. While the theoretical framework provided by Schlager and Ostrom (1992) suggests that this needs to be located first and foremost in property rights, the evidence presented here problematises such a straightforward conceptualisation. 'Nationalisation' has not resulted in take-over of property rights and the displacement of foreign corporations by economic entities owned or operated by the state, nor even by individuals who are nationals of these countries. Instead, 'nationalisation' has left enough space for foreign corporations to enter into various forms of agreements - concessions, joint ventures, etc. - that are blessed by the state. Such arrangements have not only been made within the legal remits of new constitutions that reinforced the sovereignty of these nations over their nature and natural resources, but they have in fact been used to demonstrate their effectiveness. In other words, a theory of nationalisation needs to move beyond simplistic notions of ownership and control by 'the nation', even more so in states that are or should be transformed into plurinational states.

As the preceding discussions of the changes taking place in Bolivia and Ecuador demonstrate, the signifance of the ongoing 'Left Turn' in Latin America can be found not in its shifting articulations of property rights at the operational level, but instead at the level of collective action. In other words, the relationship between nationalisation and property rights cannot strictly be located at the level of ownership, but must be considered within broader political economic dynamics concerning decisions on development politics and processes. Specifically, the changes at hand, even when they 
deal with the relatively mundane and arcane language of concessions, windfall taxes, etc. are about the ways in which collective decisions are being contested and made regarding the future shape of development in Latin America and beyond. As it has also been argued here, these changes are intimately linked to the demands of indigenous communities, as well as other groups who have been pressing their demands for radical reformulation of societal visions. To the extent that these demands have been successful, they have left an imprint on the legal design of these states - be it the shift towards a plurinational state (Radhuber 2012), granting of rights to nature (Arsel 2012), or the incorporation of civil society's demand for a post-petroleum future (Arsel and Angel 2012).

The process of contestation in which the 'nation' begins to exercise different forms of control over natural resources by using the capabilities of a strengthened 'state' is also a period of societal rethinking of the relationship between 'the nation' and 'the state'. The numerous conflicts that have emerged in Bolivia and Ecuador over extractive industries - the ongoing struggle against large scale mining in the south of Ecuador and the Tipnis road in Bolivia being just two examples - are not simply conflicts over the preservation of environmental quality or distribution of economic rents. The changing nature and significance of collective-choice rights in these new regimes make these conflicts sites in which the relationship between state and society is being contested. Therefore, nationalisation is transforming the state itself and not just its relationship with economic processes.

This is not to argue, however, that ownership is irrelevant to the study of nationalisation. Rather, the evidence coming from Bolivia and Ecuador demonstrates that it is also important to ask what is being claimed by representatives of the nation in the process of nationalisation, and furthermore what this nation actually constitutes. Thus, the focus on the stream of benefits arising from resources extraction and the associated bundles of rights must be coupled by due attention to their distribution. In fact, these rights and the new limits to their exercise that are in the hands of the State in Bolivia and Ecuador are crucially matched by changes in royalty systems and tax rates. First, these distributional changes provide new legitimacy to extraction and to the state, and are a cornerstone of the political projects of President Morales and President Correa. Second, at least at the level of ambition if not in concrete practice, new legal frameworks require that new state incomes need to be explicitly used for the further construction of plurinational states (see for example Radhuber 2012; 2013 ; 2014).

Such a position is underscored by the long and abusive history of extractive processes that have and continue to take place in these two countries, where foreign entities or their comprador associates essentially funnel 'national' wealth away from those who often own (e.g. indigenous communities) or operate (e.g. poor and marginalised classes) them. These new processes of 'nationalisation' have thus focused first and foremost on controlling the value generation process, whether through profit-sharing agreements, higher taxation, windfall taxes or other mechanisms, and aimed at financing not only social policies, but also the state transformation processes towards plurinational states.

Considered in this manner, a theory of nationalisation needs to engage with one further implication that emerges from the Bolivian and Ecuadorian examples. Nationalisation cannot be considered as a fixed moment in time that conveniently marks preand post-nationalisation phases. Instead, nationalisation, as the preceding empirical 
evidence demonstrates, is a contingent and situated historical process. The 'before' and 'after' approach risks obscuring the complex and accumulative political processes that have culminated in the current 'Left Turn' era and that is characterised by augmented state power. In fact, the process of nationalisation can be seen as a perfectly rational strategy that should be implemented, and often is implemented independently of political leanings, when the state is capturing only a fraction of the revenues generated by resource extraction (Berrios et al. 2011). A theory of nationalisation would thus first need to focus as much on explanations of continuities as it does on breakages in historical patterns. Secondly, it always has to be seen in close relation to the political project that actually motivates the nationalisation process, assuming, according to Polanyi, that economic structures must always be embedded in broader societal structures. Doing so necessitates a move beyond simplistic arguments that 'nothing has changed' or 'these are old wines in new bottles', and instead grappling with the specificities of potential forms of political and economic control over nationalised industries and the related political or transformation process.

\section{REFERENCES}

Allgäuer, A., I. Radhuber and S. Rosales (in cooperation with ETESA and INTERSOL). 2005. Mujeres cuidadoras de las minas en el Sumaj Orcko. Estudio de sus condiciones de vida. Potosí: Cimagraf.

Almaráz Paz, S. 2010. Obra completa. La Paz: Plural Editores.

Arsel, M. 2012. Between Marx and Markets? The State, the "Left Turn" and Nature in Ecuador. Tijdschrift Voor Economische en Sociale Geografie 103, no. 2: 150-63.

Arsel, M. and B. Büscher. 2012. Nature ${ }^{\mathrm{TM}}$ Inc.: Changes and Continuities in Neoliberal Conservation and Market-based Environmental Policy. Development and Change 43, no. 1: 53-78.

Arsel, M. and N. A. Angel. 2012. "Stating” Nature's Role in Ecuadorian Development: Civil Society and the Yasuní-ITT initiative. Journal of Developing Societies 28, no. 2: 203-27.

Arsel, M., and M. Spoor (Eds.). 2010. Water, environmental security and sustainable development: conflict and cooperation in Central Eurasia. Central Asian Survey 29, no. 3: 359-79.

Arteaga C. and D. Jijón. 2007. "Interview with Galo Chiriboga, Ecuadorian Minister of Mines and Petroleum." Ecuador Mining News. September 10, 2007.

Belmonte, $\mathrm{M}$ and N. Vargas. "Refundarán Comibol con cinco empresas estatales mineras." Página Siete. April 6, 2011 http://www.paginasiete.bo/2011-04-07/Economia/Destacados/ 8Eco01070411.aspx (accessed March 29, 2012)

Berrios, R., A. Marak and S. Morgenstern. 2011. Explaining hydrocarbon nationalization in Latin America: Economics and political ideology. Review of International Political Economy 18, no. 5: 673-97.

Bolivia. Ministerio de Desarrollo Rural, Agropecuario y Medio Ambiente. Plan de desarrollo sectorial. Revolución agraria y forestal. (La Paz), 2007.

Bolivia. Ministerio de Economía y Finanzas Públicas. Memoria de la Economía Boliviana 2010. (La Paz), 2011. http://www.plataformaenergetica.org/sites/default/files/mem_econ_ bol_2010.pdf (accessed May 24, 2011).

Bolivia. Ministerio de Minería y Metalurgia. Código de Minería Law 1777 17/03). 1997. http://bolivia.infoleyes.com/shownorm.php?id=532 (accessed: March 23, 2012)

Bolivia. Presidency of the Republic, Constitution of the state. (La Paz), 2009. 
Bolivia. Presidency of the Republic, Decreto Supremo (Supreme Decree) 861, (La Paz), May 1, 2001. http://www.gacetaoficialdebolivia.gob.bo/edicions/view/251NEC (accessed February 2, 2012)

Bolivia. Presidency of the Republic, Decreto Supremo (Supreme Decree) 29117. (La Paz), May 1, 2007. http://www.lexivox.org/norms/BO-DS-29117.xhtml (accessed: March 21, 2012)

Bolivia. Presidency of the Republic, Decreto Supremo (Supreme Decree) 28901. (La Paz), October 31, 2006. http://www.lexivox.org/norms/BO-DS-28901.xhtml (accessed: March 23, 2012)

Bolivia. Presidency of the Republic, Decreto Supremo (Supreme Decree) 29025. (La Paz), February 7, 2007. http://www.lexivox.org/norms/BO-DS-29025.xhtml (accessed February 2, 2012)

Bolivia. Presidency of the Republic, Decreto Supremo (Supreme Decree) 29459, February 27, 2008. http://www.lexivox.org/norms/BO-DS-29459.xhtml (accessed February 2, 2012)

Bolivia. Presidency of the Republic, Mensaje e Informe 2010. (La Paz), January 22, 2011.

Brand, U. and C. Görg. 2003. Postfordistische Naturverhältnisse. Konflikte um genetische Ressourcen und die Internationalisierung des Staates. Münster: Westfälisches Dampfboot.

Cameron, M. A. and E. Hershberg. 2010. Latin America's Left Turns. Politics, Policies and Trajectories of Change. Boulder: Lynne Rienner Publishers.

Cameron, M. A. 2009. Latin America's Left Turns: beyond good and bad. Third World Quarterly 30, no. 2: 331-48.

Castañeda, J. G. 2006. Latin America's left turn. Foreign Affairs 85, no. 3: 28-43.

Chávez, P., D. Mokrani, and L. Tapia. 2008. Document presented at the conference "Coloquio Poder y Cambio en Bolivia 2003-2007”, PIEB Programa de Investigación Estratégica en Bolivia, La Paz.

Claure Veizaga, R. 2010. Régimen Jurídico del Litio en Bolivia. Carta Informativa Legal 11 No. 40 (May 2010): 2. http://www.emba.com.bo/PDF/CIL_Mayo_2010.pdf (accessed March, 2012)

Colburn, F. D. and A. Trejos. 2010. Democracy Undermined: Constitutional Subterfuge in Latin America. Dissent 57: 11-15.

De Echave, J. 2007. Governance and Extractive Industries in Ecuador, Peru and Guatemala: the Mining Case, FOCAL Annual Report. http://www.focal.ca/pdf/indigenous_Peru_ De \% 20Echave_Gobernabilidad \%20industrias \% 20extractivas \% 20Ecuador \% 20Peru \% 20 Guatemala_2007_e.pdf (accessed March, 2012)

Demsetz, H. 1967. Toward a theory of property rights. The American Economic Review 57, no. 2: 347-359.

Denvir, D. and Riofrancos. 2008. T., How Green is the Latin American Left? A Look at Ecuador, Venezuela and Bolivia. Upside Down World. http://upsidedownworld.org/main/content/ view/1203/1/ (accessed March, 2012)

Denvir, D. 2008. Wayward Allies: President Rafael Correa and the Ecuadorian Left. Upside Down World. http://upsidedownworld.org/main/ecuador-archives-49/1396-wayward-alliespresident-rafael-correa-and-theecuadorian-left (acessed March, 2012)

Dunkerley, J. 2007. Bolivia: Revolution and the Power of History in the Present. Journal of Latin American Studies 41, no. 2: 402-404.

Ecuador. Ministerio de Recursos No Renovables del Ecuador. Plan Nacional de Desarrollo del Sector Minero 2011-2015. (Quito) 2011.

Ecuador. National Constituent Assembly 2007. Republic of Ecuador Constitution. (Quito), 2008.

Escobar, A. 2011. Latin America at a crossroads: Alternative modernizations, post-liberalism, or post-development?. Cultural Studies 24, no. 1: 1-65.

Esteva, Gustavo. 2009. Más allá del desarrollo: la buena vida. América Latina en Movimiento 445: $1-5$. 
FmBolivia, 2010. "Nueva ley minera obliga a cambiar contratos y elimina concesiones." FmBolivia, Radio Online. December 16, 2009. http://www.fmbolivia.com.bo/noticia20375nueva-ley-minera-obliga-a-cambiar-contratos-y-elimina-concesiones.html (accessed March $29,2012)$

FmBolivia. 2012. "Trabajador minero de Huanuni juró como Viceministro de Minería." FmBolivia, Radio Online.March 16, 2012. http://www.fmbolivia.com.bo/noticia79643trabajador-minero-de-huanuni-juro-como-viceministro-de-mineria.html (accessed March 21, 2012)

Francioni, F. 1975. Compensation for Nationalisation of Foreign Property: The borderland between law and equity. Int'l \& Comp.LQ 24: 255-83.

Fundación Milenio. 2011. Informe de Milenio sobre la Economía. Gestión 2010. April 2011, no 30. http://www.kas.de/wf/doc/kas_22705-1522-4-30.pdf?110812150512. (accessed March 2, 2012).

Gandarillas González, Marco. 2008. El cuarto oscuro de la privatización. In Nacionalización de los Hidrocarburos en Bolivia, ed. M. Gandarillas, M. Tahbub, G. Rodríguez, 59-97. Barcelona: Icaria.

García Linera, Álvaro. 2008. "El Nuevo Modelo Económico Nacional Productivo” Revista de Análisis. Reflexiones sobre la Coyuntura no. 2. June 8, 2008. http://www.vicepresidencia .gob.bo/IMG/pdf/revista_analisis_2.pdf

García Linera, Álvaro. 2010. "El socialismo comunitario.” Revista de Análisis. Reflexiones sobre la Coyuntura no. 5. February 7, 2010. http://www.vicepresidencia.gob.bo/IMG/ pdf/revista_analisis_5.pdf

Grugel, J. and P. Riggirozzi. 2012. Post-neoliberalism in Latin America: Rebuilding and Reclaiming the State after Crisis. Development and Change, 43 (1): 1-21.

Lang, M. and D. Mokrani. 2012. Más Allá del Desarrollo. Quito: Fundación Rosa Luxemburgo/ Abya Yala.

Latin American Perspectives 37, May 2010.

Latin American Perspectives 37, July 2010.

Levitsky, S. and K. M. Roberts. 2011. The Resurgence of the Latin American Left. Baltimore: JHU Press.

Meschkat, K. 2008. Verfassungsprozesse und soziale Konflikte in den Andenländern: neue Entwicklungen in Bolivien und Ecuador. Heinrich Böll Stiftung. Die Grüne politische Stiftung. http://www.boell.de/downloads/Verfassungsprozesse_Bolivien_Ecuador_Meschkat .pdf (accessed December 18, 2011)

Molero, R. and M. J. Paz, 2012. Development strategy of the MAS in Bolivia: Characterization and initial results.Development and Change. 43, no. 2: 531-556.

Moreno Baldivieso, R. 2010. Perspectiva del régimen minero en la Constitución. Carta Informativa Legal (Year 12) 11 (40) http://www.emba.com.bo/PDF/CIL_Mayo_2010.pdf

OBIE (Observatorio Boliviano de Industrias extractivas). "Concesiones Mineras: Política minera del gobierno reforzará el liderazgo del capital transnacional.” El Observador. Boletín Informativo del Observatorio Boliviano de Industrias Extractivas no.5. October, 2008. http://plataformaenergetica.org/obie/system/files/obie_5_0.pdf

Ortiz, P. 2011. Extractive Capitalism, Mining and Rights: Can They Live Together? Íconos. Revista de Ciencias Sociales. 39: 11-23.

Ostrom, E. 1990. Governing the Commons: The Evolution of Institutions for Collective Action. New York: Cambridge University Press.

Pellegrini, L. 2011. Forest management and poverty in Bolivia, Honduras and Nicaragua: reform failures? European Journal of Development Research 23, no. 2: 266-283.

Pellegrini, L. 2012. Planning and natural resources in Bolivia: between rules without participation and participation without rules. Journal of Developing Societies 28, no. 2: 185-202. 
Pellegrini, L. and A. Dasgupta. 2011. Land reform in Bolivia: the forestry question. Conservation and Society 9, no. 4: 274-285.

Prada, R. 2012. Horizontes del Estado Plurinacional. In Más Allá del Desarrollo, ed. M. Lang, and D. Mokrani, 159-185. Quito: Fundación Rosa Luxemburgo/ Abya Yala.

Radhuber, I.M. 2008. El poder de la tierra. La Paz: Plural Editores.

Radhuber, I.M. 2014: El Estado plurinacional en Bolivia. EL papel de la política de presupuestos y de recursos naturales (Working Title). La Paz: Oxfam/PLURAL (forthcoming).

Radhuber, I.M. 2012. Indigenous Struggles for a Plurinational State: An Analysis of Indigenous Rights and Competences in Bolivia, Journal of Latin American Geography, Volume 11, Number 2, 167-193.

Radhuber, I.M. 2013. Der plurinationale Staat in in Bolivien. Die Rolle der Budget- und Ressourcenpolitik. Münster: Westfälisches Dampfboot (forthcoming)

Reuters. "Bolivia inaugurará con Suiza Glencore cambio de contratos." Reuters América Latina March 20, 2012. http://lta.reuters.com/article/businessNews/idLTASIE82J0A120120320 (accessed March 20, 2012)

Revista Minera. "Bolivia: Nueva Ley Minera obligará a empresas a reinvertir parte de sus utilidades en el país.” June 18, 2010. http://revistaminera.wordpress.com/2010/06/18/ bolivia-nueva-ley-minera-obligara-a-empresas-a-reinvertir-parte-de-sus-utilidades-en-el-pais/ (accessed: March 23, 2012)

Santacruz, S. "Ecuador's Attractive Mining Law May Raise Fees.” Ecuador Mining News, June 18, 2007. www.ecuadorminingnews.com

Schlager, E. and E. Ostrom. 1992. Property-Rights Regimes and Natural-Resources - a Conceptual Analysis. Land Economics 68, no. 3: 249-262.

Tahbub, M. 2008. Una introducción necesaria. In Nacionalización de los Hidrocarburos en Bolivia, ed. M. Gandarillas Gonzales, M. Tahbub, and G. Rodríguez Cáceres, 17-29. Barcelona: Icaria.

Tahbub, M. 2008. Las nacionalizaciones petroleras del siglo XX. In Nacionalización de los Hidrocarburos en Bolivia, ed. M. Gandarillas Gonzales, M. Tahbub, and G. Rodríguez Cáceres, 29-59. Barcelona: Icaria.

Varela M. 2010. Las actividades extractivas en Ecuador. Ecuador Debate no. 79. Conflictos del extractivismo, (April): 127-150 http://www.ecuadordebate.com/wpcontent/uploads/2010/04/Ecuador-debate-79.pdf

Vega Camacho, O. 2010. Al sur del Estado. In: El Estado. Campo de lucha, ed. A. García Linera, R. Prada, L. Tapia, and O. Vega Camacho, 129-165. La Paz: CLACSO / Comuna/ Muela del Diablo.

Villegas Quiroga, C. 2004. Privatización de la industria petrolera en Bolivia. Trayectoria y efectos tributarios. La Paz: CIDES-UMSA/ CEDLA/ FOBOMADE/ DIAKONIA. Plural Editores. Second edition.

Wallerstein, I. 2007. World System Analysis: An introduction. Durham/ London: Duke University Press. Fifth edition.

Wanderley, F., L. Mokrani and A. Guimaraes. 2010. Las políticas hidrocarburíferas en Bolivia: La difícil articulación entre las dimensiones técnico-económica y político-simbólica. Umbrales. 20: 71-100.

Webber, J. 2010. From rebellion to reform. Bolivia's reconstituted neo-liberalism. International Socialist Review, no. 73 (September-October). http://www.isreview.org/issues/73/featbolivia.shtml

Wehr, I. 2011. Einleitung: Zur problematischen Koexistenz von Demokratie und eklatanter sozialer Ungleichheit in Lateinamerika. In Soziale Ungleichheiten in Lateinamerika. Neue Perspektiven auf Wirtschaft, Politik und Umwelt, ed. Wehr and Burchardt, 9-28. Baden-Baden: Nomos. 


\title{
Engaging Legal Systems in Small-Scale Gold Mining Conflicts in Three South American Countries
}

\author{
Marjo de Theije ', Judith Kolen ${ }^{2}$, Marieke Heemskerk ${ }^{3}$, \\ Celine Duijves ${ }^{4}$, Mariana Sarmiento ${ }^{5}$,Alexandra Urán ${ }^{6}$, \\ Ingrid Lozada ${ }^{7}$, Helcías Ayala ${ }^{8}$, Jorge Perea ${ }^{9}$ \& \\ Armin Mathis $10, \mathrm{II}$
}

\begin{abstract}
This chapter addresses the relationship between engaging legal systems and the incidence of conflicts in small-scale gold mining. We concentrate on the conflicts that are the result of claims made by different stakeholders in their attempt to gain access to gold-rich soils and rivers and the revenues thereof. Each of the countries studies here - Suriname, Colombia and Brazil - have a complex set of laws, rules and regulations with regard to territory and natural resources. However, in many smallscale gold mining regions, the role of the state in implementing mining legislation and exercising authority has been marginal. Incompatibilities in the legal system and the lack of state laws form an important obstacle to the effective formulation and implementation of public policies for small-scale mining activities, and cause conflict in the respective local settings. By comparing the three cases, we make an inventory of the different legal systems, how these are interrelated and how people make strategic choices between them. This is what we call "engaging legal systems": the laws and regulations that interact in a situation of legal pluralism, and the users of the laws and regulations who relate to the different legal systems. We argue that the lack of state authority can be an important reason for the engagement of different legal systems. However, engaging legal systems are a common phenomenon in small-scale gold
\end{abstract}

\footnotetext{
${ }^{1}$ Researcher at Centre for Latin American Research and Documentation and Associate Professor at VU University, Amsterdam, Netherlands (Corresponding author: M.E.M.deTheije@cedla.nl.)

${ }^{2}$ Researcher at Centre for Latin American Research and Documentation, Netherlands.

${ }^{3}$ Consultant at Social Solutions Suriname.

${ }^{4}$ Consultant at Social Solutions Suriname.

${ }^{5}$ Independent Consultant in Environmental Policy and Management.

${ }^{6}$ Associate Professor at University of Antioquia, Colombia.

${ }^{7}$ Executive Director at Fundación Amigos del Chocó, Colombia.

${ }^{8}$ Instituto de Investigaciones Ambientales del Pacifico, Colombia.

${ }^{9}$ Community Leader, Miner and Activist from Chocó, Colombia.

${ }^{10}$ Associate Professor at Federal University of Pará, Center for Advanced Amazon Studies (UFPA/NAEA), Brasil.

${ }^{11}$ The authors of this chapter are all part of GOMIAM, a consortium that studies smallscale gold mining from a comparative, multi-disciplinary and multi stakeholder perspective. GOMIAM aims to contribute to the elaboration of adequate public policies regarding smallscale gold mining and the communities affected by the mining activities, thereby enhancing the sector's environmental, social and economic sustainability in Bolivia, Brazil, Colombia, Peru and Suriname.
} 
mining regions, even when state mining legislation exists. Understanding engaging legal systems is a prerequisite for the formulation of more adequate policies and the mitigation or solution of conflicts.

Keywords Small-scale gold mining, engaging legal systems, legal pluralism, conflict, Brazil, Colombia, Suriname.

\section{I INTRODUCTION}

This chapter addresses the relationship between legal pluralism and the incidence of conflicts in small-scale gold mining in the Amazon. Economic growth and crisis, environmental concerns, and the social consequences of the extraction of natural resources all contribute to the importance of mining in the 21 st century. Gold mining is currently one of the most rapidly expanding industries in the world. The price of gold started rising a decade ago and has quadrupled in less than ten years. Large and mid-scale extraction by international mining corporations has significantly benefited national economies. Small-scale gold mining has attracted a large number of individuals who see opportunities for social and economic development. It is estimated that such activities support the livelihoods of over 100 million people in more than fifty countries (Spiegel and Veiga 2007), while employing a total of 15 million directly (ICMM, CASM, and CommDev 2010).

Gold mining is also one of the most important economic activities in the Amazon region. In Suriname, for example, it supports the livelihoods of an estimated 60,000 people (12\% of Suriname's population) (Hammond et al. 2007; ICMM, CASM, and CommDev 2010). In Colombia, approximately 15,000 families live off small-scale mining (Defensoría del Pueblo Colombia 2010), and in Brazil the sector employed around 200,000 miners in 2010 (Sousa et al. 2011.). By small-scale gold mining we refer to mining that is labour-intensive, poor in technology, mostly outside the formal legal frameworks of nations and often out of sight of national policies. Some small-scale mining is artisanal and manual, occasionally using no more than a pump to push water. In other forms, miners use excavator machines, multiple pumps and grinding mills. This mining is still called small-scale because the working units operate independently and are solely comprised of the number of people necessary to have all of the machinery running, usually four to six men.

The expansion of the small-scale gold mining sector in the Amazon countries is characterised by migrating mining populations, deforestation, uncontrolled release of mercury, the deterioration of soils and riverbeds, inefficient mining operations that are not based on thorough prospection, and dangerous working conditions. With unprecedented numbers of people entering the small-scale gold mining industry, gold mining also causes many conflicts between different populations, and between miners, communities and the state. These conflicts are the result of the unauthorised occupation of land, conflicting claims on the access to gold-rich soils and rivers, or equally conflicting claims by different stakeholders on the revenues of the mineral wealth. Although small-scale gold mining is an important economic sector, one in which many poor people find a living, public policies are not adequate to deal with conflicting claims. In all countries, the sector remains rather uncontrollable; it takes place in remote parts 
of most countries and is outside the direct influence of state administrations. In each of the study sites, Brazil, Colombia and Suriname, national governments encounter difficulties regulating small-scale gold mining activities within their borders. Conflicts between different stakeholders form an important obstacle to the effective formulation and implementation of public policies for the small-scale gold mining sector.

We concentrate on the conflicts that are the result of competing claims made on the access to gold and its revenues. Legal and political conditions form the root cause of these conflicts. Barreto (2011) reasons that many of the problems that are usually ascribed to small-scale mining are actually rooted in the marginalisation of the sector, itself arising from obstacles to legalisation. Small-scale gold mining communities are often described as uncontrolled, wild, informal, or even illegal and criminal (Spiegel and Veiga 2007; Theije and Heemskerk 2009; Tschakert 2009; Sousa et al. 2011). This, however, does not mean that regulatory legal systems are absent in mining areas. By contrast, complex sets of laws, rules and regulations exist and function as parallel legal orders. In the legal anthropological literature, the mixing and mutual influencing of different legal orders, changing behaviour and thinking is called interlegality (Simon Thomas 2009).

In this chapter we develop the notion of engaging legal systems to analyse and compare the circumstances under which legal pluralism causes, helps mitigate or facilitates the management of mining-related conflicts. The next section provides theoretical considerations about legal pluralism and the notion of engaging legal systems. We subsequently analyse the interplay between different legal systems, such as national laws, unwritten miner's laws and customary community regulations in and around mining areas, in specific regions of Brazil, Colombia and Suriname. In the last section we will compare the different study sites and argue that gaining a comparative and deeper understanding of conflicts and their possible solutions is a precondition for policies that aim for responsible mining. This discussion is relevant, because legalisation of small-scale mining is seen as a necessary public policy to enhance the environmental, economic and social sustainability of the gold mining industry (cf. Barreto 2011).

\subsection{ENGAGING LEGAL SYSTEMS}

Legal pluralism is defined as the presence of "more than one legal order or mechanism within one socio-political space, based on different sources of ultimate validity and maintained by forms of organization other than the state" (Benda-Beckmann 2002: 37; cf. Griffiths 1986). In discussing small-scale gold mining, we use 'engaging legal systems' to emphasise that different systems exist and are meaningful for different groups of people, have authority for different groups of people, stand in relation to one another, and interact. As we will demonstrate in this chapter, 'engaging' also implies that these legal systems are in dialogue with each other. Mining-related conflicts can be caused or mitigated by adopting this dialogue. The different legal orders are usually the formal legal system of the state, and other - sometimes called informal - orders, such as customary law, local laws pertaining to specific ethnic groups or religious laws, or regulations related to specific activities. State law frequently does not formally recognise the existence of other legal orders, such as customary law or local law. This type of legal pluralism is called real, factual (de facto) legal pluralism (Simon Thomas 
2009) or social, empirical legal pluralism (Hoekema 2005: 4). Official or formal (de jure) legal pluralism indicates a situation whereby the existence of multiple legal orders is reflected in national law. When looking at processes of engaging legal systems, the distinction between de facto and de jure legal pluralism is essential. Hoekema argues that "the moment local law is recognised formally as partner in the national legal order, conditions for interlegality may change" (2005: 4). When addressing questions of interlegality the legal systems themselves become the focus of the research.

The concept of engaging legal systems fits in a social scientists' approach, which understands law broadly as the cognitive and normative orders that are produced and reproduced in a social field. Social scientists stress that in such fields, individuals and groups can make use of more than one law to rationalise and legitimise their claims, decisions or behaviours. ${ }^{12}$ Falk Moore (1973:720) argues that such social fields are semi-autonomous, by which she means that "it can generate rules and customs and symbols internally, but it is also vulnerable to rules and decisions and other forces emanating from the larger world by which it is surrounded" (Moore 1973: 720). Legal pluralism should therefore be understood "not as a plurality of separate and bounded cultural systems, but rather as a plurality of continually evolving and interconnected processes enmeshed in wider power relations" (Sieder quoted in Simon Thomas 2009: 24). It implies that two or more legal systems operate in a social field at the same time, and may appeal to people's values in different (sometimes conflictive) ways in similar cases.

As our interest goes to the relationship between conflict and legal systems, we will not exhaustively elaborate on the various ways in which one can classify legal systems. Instead we turn to the question, when do law and rights become an issue in conflicts about small-scale gold mining? Most of the time the root of the mininginduced conflict has to do with claims for access and rights to the mineral or revenues derived from its mining. Such claims are legitimised with reference to legal orders, be they formal, customary or otherwise. The reigning mining rules are lived and created by active agents who are constantly negotiating their own position within the social field of small-scale mining. The conflicts arise when different actors base their claims in different legal orders, or when legal orders clash or engage in conflicting ways. This leads us to studying the engagement of different legal orders that operate in a mining related conflict, how miners make use of these orders, and how engaging legal orders either cause or mitigate conflict.

Other conceptual distinctions are insightful here, such as the distinction made between illegal (prohibited by law) and illicit (socially perceived as unacceptable) practices (Van Schendel and Abraham 2005). Accordingly, for example, it is illegal to mine gold without an exploitation concession in most countries, but in many countries it is licit and socially accepted that many people do. The illicit is subject to change, in time, place and between states. Some actors may be involved in the contestation of the illicit practice, especially when the legal boundaries are fuzzy, as is often the case in weak states who take no effort to enforce the mining law, or when a mining law is absent.

\footnotetext{
${ }^{12}$ This notion of choice is often linked to the concept of "forum shopping" in anthropological studies of legal pluralism. "Forum shopping refers to the choice one of the parties makes between two or more legal systems and their authorities that are empowered to consider the case at hand" (Simon Thomas 2012: 93).
} 
This creates a need for regulatory systems and space for customary and informal legal orders to arise.

In Suriname most gold is mined in irregular situations. That is, without mining titles. Although the law does not permit it, national entrepreneurs sublet part of their concessions to migrant miners. A whole set of informal rules and regulations then takes effect to organise this subletting of mining plots. These informal arrangements exist outside of the national formal law, but not outside of local rules and laws. It shows that formal law is not the only regulatory system in mining regions and that parallel legal systems co-exist and can be effective. It is important to understand where and when different legal systems interact. Under which circumstances are these engagements constructive or do they cause conflict, and for or between whom? In research on small-scale gold mining, it is interesting to look for elements of customary law that have become part of a newly developed and dynamic local law. It might, however, be as plausible to assume that many customary rules are gradually being infringed or adjusted to fit into a dynamic and quickly changing mining setting.

Whatever legal systems are in effect, it is important to note that they are seldom static. Such a conception does not do justice to the complex process of negotiation, positioning and creation by individuals and groups of people. The individual stakeholders in the mining sector engage with rules and rights, and the different legal systems may be adapted to some extent. But these systems also engage with and therefore influence each other, precisely because they exist together. Of course, this is not only the case with small-scale gold mining rights. In other regions and sectors, customary law, local law and traditional law are all terms referring to sets of rules that have been accepted and used by local communities, and have to be taken in consideration in the study of engaging legal systems. The merit of the legal pluralism approach is that it forces us to concentrate on the empirical reality behind a particular legal order and its effects on people's claims and rights in relation to the natural resources. Taking the local as a starting point for analysis helps us understand the dynamics of rule-making and norms, and discover the roots of conflicts as well as strategies to mitigate such conflicts.

In the Amazon, small-scale gold mining is often considered illegal and informal because they fall outside the scope of national mining laws. Additionally, there are no clear regulations about the "property" of the mineral resources. The property rights over the resources include the rights to use resources, but also the rights to take decisions and regulate control. Meinzen-Dick and Pradhan (2001: 10-17) argue that the implications of legal pluralism for natural resource management lie in an alternative way to view property rights and resource users' relationship with natural resources. Rather than seeking a single definition of property rights, it is better to recognise the multiple and often overlapping bases for claims, and to regard property rights and the uses of natural resources as negotiated outcomes.

In the following sections, we analyse how legal systems engage in the context of small-scale gold mining in the Amazon, under which circumstances these engagements are constructive or cause conflict, and for or between whom. We will provide three cases, each with different legal systems operating on the local level, engaging in particular ways with particular results. The comparison of these cases will illustrate that the study of the different legal orders that exist in the mining practice of gold miners in Suriname, Colombia and Brazil gives insight into the conflicts on different scales. 


\subsection{THE CASE OF NIEUW KOFFIEKAMP (SURINAME)}

In Suriname the tribal village Nieuw Koffiekamp did not find protection of its interests in national law when the government granted their territory to a multinational mining company. The absence of adequate national legislation for small-scale mining, in combination with the customary legal system of the Ndjuka Maroon community, gave rise to many years of negotiation between the company, the government, the community authorities and local small-scale miners. After years of protests, small-scale gold miners from the Ndjuka community succeeded in acquiring the informal right to mine on the multinational's concession. Their formal rights remain elusive, however, and they have to renegotiate their position time and again.

Nieuw Koffiekamp is a Maroon community of about 500 people in the rainforest of Suriname, some $100 \mathrm{~km}$ south of Suriname's capital city of Paramaribo. Maroons are tribal peoples of African descent who live in the rainforest. They have their own languages, cultural traditions, religious and leadership structures, and customary laws and regulations that have developed over almost three centuries. About $20 \%$ of the Surinamese population is Maroon, and in the inlands they are by far the largest group. The Ndjuka are one of the six Surinamese Maroon tribes. The Ndjuka of Nieuw Koffiekamp claim exclusive and inalienable rights to the village grounds and surrounding lands that they use for productive activities, such as subsistence agriculture, hunting, fishing, timber harvest and small-scale gold mining. They base their claims in the customary law and written agreements that were part of the peace treaties between the colonial government and the Ndjuka, established in the 1760s. However, these rights to land and natural resources are not recognised by the contemporary formal law.

In the interior of Suriname, customary law was not contested until recently. The Maroon groups generally agree about the boundaries between clans and tribes, and about who has the right to use certain natural resources in their own territory and on the lands of others. For example, one may generally hunt and collect forest products for own use in an area claimed by another clan, but for commercial activities one needs the permission of tribal authorities. In the case of gold mining, it is common practice that an operation owner pays a tribute to the tribal authorities in the villages, usually some percentage of the earnings. This rule also applies to non-Maroon outsiders, such as Brazilian miners who have been coming to the country's gold fields in large numbers since the 1990 s - they usually pay $10 \%$ of the produce to the village elders.

In 1994, the Suriname state granted the Canadian exploration firm, Golden Star Resources, exclusive rights to the 17,000 hectare Gros Rosebel concession that overlaps the Nieuw Koffiekamp territory. This precipitated two conflicts: first, the village was located centrally in the concession and the villagers were never consulted or even informed (Heemskerk and van der Kooye 2003); and second, a considerable number of small-scale gold miners were active in the area, the majority of whom came from outside of Nieuw Koffiekamp. Tensions increased when Golden Star Resources asked the miners to leave the concession (Healy 1996). By formal law the company had the right to send the miners away, and even the right to mine under the village. However, in an effort to avoid humanitarian problems, the government and the company tried to negotiate. The commencement of negotiations was followed by alternating periods of peace and conflict. By the end of 1994, in an effort to settle the conflict for good, 
the government promised the Nieuw Koffiekamp gold miners an area of 8,000 ha outside of the concession. As a precondition, all small-scale miners would leave the Gros Rosebel concession. The Ndjuka miners from the Nieuw Koffiekamp community objected, however, because the selected zone was too far from the village $(18 \mathrm{~km})$ and situated in the traditional territory of another Maroon tribal group, the Matawai (Brana-Shute et al. 2001).

The opposing interests of government, company, small-scale gold miners and Nieuw Koffiekamp villagers continued to clash. In the following years, conflicts between the small-scale gold miners and the company erupted in various forms and degrees of intensity (Commissie voor Nieuw Koffiekamp 1996; Healy 1996; BranaShute et al. 2001). In 1995, Nieuw Koffiekamp residents complained that they were intimidated and fired at by company guards and police units, allegations that were substantiated by Suriname's main human rights organisation (Healy 1996). In response, the villagers built roadblocks to prevent access to the company plant. This incident motivated the establishment of the Commission for Nieuw Koffiekamp, composed of representatives of the national government, village authorities, and tribal leaders with the purpose of achieving a compromise (Healy 1996). The Commission drafted an agreement, which stated that the community lands of Nieuw Koffiekamp would be demarcated, presumably as a first step towards the legal recognition of the tribal land rights. Furthermore, the gold miners of Nieuw Koffiekamp would obtain an alternative mining concession, outside the Gros Rosebel property, and suspend mining activities on the company concession. Gold miners from other villages were excluded. The Nieuw Koffiekamp gold miners initially approved of the draft agreement and withdrew their machines from the concession. However, when both the government and the company failed to respond to the agreement and thus did not live up to promises of demarcation and alternative mining grounds, the gold miners restarted mining at the company concession (Healy 1996; Brana-Shute et al. 2001). They legitimised their behaviour by arguing that this was their tribal land and hence they, not the company, were the rightful owners of its resources. This illustrates how the Nieuw Koffiekamp community operates as a semi-autonomous social field (Moore 1973: 55), engaging different legal orders to counter emerging threats.

Today, the legal rights to the former Golden Star Resources concession are owned by mining multinational Iamgold, which operates locally as Rosebel Gold Mines N.V. The earlier conflicts have not been resolved, but the Nieuw Koffiekamp community and the large-scale mining company have meanwhile managed to create a peaceful coexistence. The initiation and maintenance of this ceasefire have largely been facilitated by the self-organisation of the Nieuw Koffiekamp gold miners. Through gold miners' organisation Makamboa, the Nieuw Koffiekamp miners now collectively negotiate with the company. Makamboa counts about 50 machine owners and some 500 workers among its members. Among its main accomplishments is that the associates may mine within the boundaries of the Rosebel Gold Mines concession, as long as they comply with certain requirements. These requirements include the exclusion of migrant miners and sex workers, and clearance of defined industrial zones where the company is active.

In 2010, an agreement was signed between the Mediation Board/Ministry of Natural Recourses, District Commissioner, Rosebel Gold Mines, a representative of Police and Makamboa. This agreement does not explicitly mention the right of the 
Nieuw Koffiekamp gold miners to mine on the Gros Rosebel concession, even though the gold miners interpret it as such. It only states that 25 registered groups of Makamboa members and their mining equipment will obtain badges, and that "Rosebel Gold Mines is willing to consider reasonably how it can assist Makamboa logistically to develop legal activities in the triangle area/exploration as discussed in the meeting" (Agreement 2010, emphasis added). The purpose of the "badges" and the exact meaning of "willing to consider" remain undefined. According to the company, Rosebel Gold Mines cannot formally allow small-scale gold miners to mine on its concession because the national mining law states that only the national mining authority can extend mining permits. According to observers, the wording was intentionally kept vague because the company does not want to sign a binding agreement that would prevent the expulsion of small-scale gold miners at some later date. During the negotiations, local government officials played a mediating role, but did not actively intervene in the wording of the agreement, which now functions as an informal local law. Through this agreement the government and the company tolerate the activities of Nieuw Koffiekamp gold miners on certain lands around their village without legitimising them and recognising their customary land rights.

In their negotiations with the government and the mining multinational, the Makamboa gold miners have formed their own semi-autonomous social field. They recreate customary tribal law to claim the rights to the mining grounds, but blend the Maroon rules with additions based on the legitimation they receive from the negotiations with the company and state representatives. The group has developed and enforces its own rules regarding who are and who are not "Koffiekamp miners," the obligations of miners, and sanctions for those who do not comply. One of these obligations suggests that associated miners who work within the Rosebel Gold Mine exploitation concession have to pay a percentage of their earnings to Makamboa. Makamboa, in turn, hands this money to the Nieuw Koffiekamp women's organisation, which deposits it in a bank in the capital city. The community members collectively determine the money's final destination. Thus far, the miners' "taxes" have contributed to the extension of the elementary school, and the construction of a clinic, government offices, a recreation centre and a modern air-conditioned meeting hall for the village.

A pressing new problem is that, with the current exorbitant price of gold, the company may assert its legal right to exploit gold deposits near and underneath the village. The mining multinational is already moving closer to the village of Nieuw Koffiekamp than was previously foreseen. Dynamite blasting is disturbing the community members and producing cracks in the cement walls of the school and houses. If the situation worsens, villagers may have to leave.

The developments of the past two decades demonstrate that, when confronted with invaders of their homelands, the Nieuw Koffiekamp community members have enhanced their skills to engage with different legal systems. They engage with the available legal systems and recombine them for their own purposes and in their own way. Nieuw Koffiekamp inhabitants base their right to mine for gold on their tribal status and the related customary law system. Despite their strengthened position vis-à-vis the mining multinational, the Nieuw Koffiekamp community and its gold miners remain vulnerable. Due to the fact that customary tribal laws have no national legal backing and because most arrangements with the company are based on oral agreement, the community continues to risk losing its homelands. 
There is another legal order that increasingly plays a role in the conflict: transnational norms and laws. Both the Nieuw Koffiekamp community and its miners, and Iamgold are well aware of the fact that the sympathy of the international community is normally with tribal peoples; no one roots for Goliath. In this setting, international human rights laws shape negotiations between small-scale gold miners, who justify their behaviour on the basis of tribal customary laws, and the mining multinational, which is backed by a legal mineral agreement with the Suriname government. The mining company's decision to allow local tribal gold miners on the concession was not motivated by altruism. In the watchful eye of the international community, the forced expulsion of tribal peoples would reflect poorly on the company. A compromise that allows the multinational to mine profitable deposits while (temporarily) giving permission to small-scale gold miners to mine the top-layer is in its own best interest. The Maroons have international laws and regulations on their side. However, it has yet to be seen to what extent World Bank development guidelines, UN regulations, the American Convention on Human Rights, and international Best Practices guidelines for large-scale mining companies, can compete with national laws and - even more so - the lure of a pot of gold.

The story of the Nieuw Koffiekamp mining community suggests that the engagement with different legal systems has been effective in mitigating the conflict over access to land and gold. For the company, the incorporation of customary laws of local miners and communities into (informal) company policy can help reduce conflict between local gold mines and a mining company. The Nieuw Koffiekamp community, and especially the miners' organisation Makamboa, have also engaged with other legal orders than the customary law, using formal law ${ }^{13}$ to defend their position in the concession. In the establishment of this workable - mostly unwritten - agreement between the company and small-scale gold miners, the role of the state and formal legislation has been marginal. The one exception to this is that the mining concession has been given on the basis of state law, creating the foundation of the current conflict.

\subsection{THE CASE OF CHOCÓ (COLOMBIA)}

The legal situation is very different in the Colombian region of Chocó. In this region, the collective land rights of the Afro-Colombian population are officially recognised and there is de facto legal pluralism. The local Afro-Colombian communities have been granted collective land titles and artisanal mining rights that are governed by so-called Community Councils. The communities have no rights to the subsoil however, and the Ministry of Mines has granted mining titles within the collective titles to outsiders. The area is abound with illegal mining. This region possesses some of the most important reserves of gold and platinum in the country and mining activities have taken place for more than 200 years. Both large-scale and small-scale miners have interests in the deposits, including the producers of so-called artisanal "green" gold. At the moment, there are no large companies involved in exploitation, but there are hundreds of

\footnotetext{
${ }^{13}$ In this context international normative law also plays an important role. In another writing the authors will pay attention to the question how the miners' organization Makamboa engages with international normative orders to negotiate their position in this territory.
} 
small-scale mining operations. Notwithstanding the de facto legal pluralism and collective land rights of the Afro-Colombian people, there are many conflicts over the land and the access to gold rich soils.

The formal legal situation is not sufficient to organise the small-scale mining sector. In response to the contradictions over the use of natural resources, communities and miners have developed informal norms to cope with the situation. Such informal arrangements contribute to a state of de facto legal pluralism and to engaging legal systems. The parties, however, are different than in the case of Suriname: AfroColombian artisanal miners, Community Councils, mechanised migrant miners from outside the region, municipal administrations and illegal armed groups. Although they are not necessarily mining at the moment, large-scale mining companies are also actors within, because they have interests in the region and have been granted mining titles by the Ministry of Mines.

The preservation of cultural and ecological diversity are guaranteed in the Constitution of Colombia. Law 70 of 1993 assigned and recognised collective land rights of Afro-descendants and also established locally elected Community Councils as local authorities. Law 21 established mechanisms for protecting the cultural identity and rights of these communities through free prior and informed consent (FPIC) requirements. Although ethnic communities therefore have the right to self-determination, their internal laws cannot contradict the constitution or any other law that has national reach (Lugo 2006: 212). Additionally, environmental law 93 mandated government agencies to work with indigenous and black communities in the conservation and sustainable use of the resources in the region. To this end an environmental authority (Codechoco) was created.

Artisanal mining has developed inside legally recognised mining areas of the AfroColombian communities, and this type of mining does not require additional mining titles or licences. Miners use simple technologies as well as small dredges and pumps. Within these collective titles, the Community Councils are the official managers of natural resources and are free to allow artisanal miners to work. Artisanal mining is mainly done on the collective land titles of Afro Colombian communities. There are some specific agreements between the miners and the community, as the collective land titles are locally divided among families. In some cases, after covering the production costs (pay for fuel, food and cook), 50 percent of the profits go the owner of the motor or the Afro-Colombian landowner, while the remaining 50 percent is divided equally among the different workers. In other cases, after costs are covered, what remains is divided equally among the total number of "posts": one for each worker, one for the equipment, one for the engine and one for the landowner. These last three items are usually owned by a single person who is typically the head of the production unit. Depending on the location of the mine, different mining methods are used. The most traditional and smallest artisanal miners do not use chemicals - mercury and arsenic for beneficiation.

The artisanal miners of Condoto and Tadó have consolidated responsible social and environmental practices in alliance with NGOs (Amichocó and ARM). Some of these miners have certified their own practices with the fairtrade/fairmined label in order to obtain a premium for their products. This type of mining causes a low environmental impact and there are no conflicts with the local communities. The lack of state recognition for this form of small-scale gold mining is, however, an obstacle to 
further development of the sector in the Afro-Colombian communities. According to the state's definition, there is no place for elaborate techniques in artisanal mining, as only panning is considered. This definition rejects the complexity of artisanal mining and obscures their practices, making the communities more economically vulnerable and invisible. Moreover, there is an expectation that traditional communities remain static in their artisanal mining practices, which prevents them from increasing their productivity and income.

Mechanised miners are typically from outside of the Chocó region and use heavier equipment including excavators. Unlike artisanal miners, these miners are required by law to have mining titles, a concession agreement and an environmental licence from the national mining department (Ingeominas) and the regional environmental authority (Codechoco). This requires proof of financial and technical viability of the mining operation, as well as a detailed environmental management plan. Most of them do not fulfil these legal requirements and are therefore considered illegal. Some of these miners have ties to guerrilla and paramilitary groups and narco-traffickers. They establish agreements with the municipal administrations that authorise their mining activities, despite not having legal mining titles. Municipal administrations charge approximately USD 900 for the construction of the mine and a monthly fee of USD 250 while it is operating. Such agreements also establish a set of minimal environmental management conditions that may include the prohibition of mining operations during the weekends in order to avoid visible water pollution on these days. This is important for communities, because the weekends are the time for families to enjoy the river. Sometimes municipal administrations require miners to allow members of the community to pan in their mines. There are two reasons for this: (1) it is a means of generating income for community members, and (2) it creates acceptance of mining activities among the local community. The competition between the artisanal miners and mechanised miners is one source of conflict in the Chocó gold fields.

Apart from the "authorisations" from municipal authorities, the mechanised miners have to make agreements with the Afro-Colombian landowners, the families that derive their private land titles from the collective land rights of the community. Typically in this situation, miners have already made arrangements with municipal mayors, the public officials who are in charge of administering land use. Municipal administrations have an important influence on how mineral resources are exploited, because in practice they are the main local environmental authority and the main regulatory entity. They are the entity responsible for developing municipal land use plans, as well as granting land use permits. It is worth noting that, in contrast to national and regional environmental authorities, municipal authorities also have policing authority, a jurisdiction that allows them to decide whether or not measures will be taken to close down mines. Depending on the conditions of the land, the Afro-Colombian landowners' capacity to negotiate, and how promising the deposit looks, mechanised miners must pay them between $10 \%$ and $15 \%$ of the total production. In other cases they pay a rental fee based on the same criteria. Sometimes landowners will set environmental management requirements such as backfilling intervened areas. These requirements are however not always met, and the landowning families do not have the means to enforce the tenants.

Local Community Councils, who are the administrative bodies of the AfroColombian collective titles, also have agreements with mechanised miners that work 
inside their collective territory. Like municipal mayors, local councils charge a percentage of the monthly production, usually $1 \%$. However, miners typically ignore local Community Councils and only establish agreements with the landowners and municipal Mayors directly. Community Councils may have made agreements with the migrant mechanised miners to find financial compensation for the environmental damage caused, but this is not enforced. Finally, illegal armed groups in the area will charge approximately USD 700 for every excavator or $15 \%$ of the total production. If miners do not comply, their lives are at risk.

Another cause of the conflict that occurs in the regions is derived from the fact that collective land titles overlap with National Forest Reserves - where all mining, mechanised and artisanal, is prohibited. These reserves contradict the right and the tradition that black communities have to artisanal mining. Furthermore, despite the mining prohibition established by the Ministry of Environment in these National Reserves, the regional environmental authority has in the past taken measures that act as though miners legally work in the Reserve. They required the mechanised miners to develop an environmental compliance plan to decrease their negative environmental impact, and also establish a procedure for the forfeiture of the machinery being used in case they would not comply with the rules. This way, mining in the forest Reserve has become legitimised, even when it is outside formal state law.

In sum, next to the de jure legislation, there is a whole set of de facto agreements that organise small-scale mining in Chocó that ensures that artisanal and mechanised miners and local communities can coexist. Miners and local communities engage with different legal systems in such a way that a system of regulating norms for the mining sector has emerged. These informal norms have legitimised mining practices through agreements between the most important stakeholders, such as the municipal administrations, landowners, community councils, illegal armed groups, mechanised miners and artisanal miners. The ensuing legal system provides some sort of social stability in the absence of national governmental control, as well as economic resources to local artisanal miners and panners who operate in the the mechanised miners' pits. These informal arrangements are not, however, beneficial to local communities as a whole. Mining rents go to some individual Afro-Colombian landowners, and to outsiders and the local natural environment is heavily impacted by the mechanised approach.

The Chocó region abounds with latent and manifest conflicts. Municipal authorities allow mechanised miners to operate within collective territories without consulting Community Councils. Similarly, Afro-Colombian landowners who are part of Community Councils do not consult the traditional authorities of the collective title. In the end, traditional authorities are not being recognised, which jeopardises their legitimacy in the decision-making arena. The collective rights of the communities are violated in the agreements set around small-scale gold mining.

\subsection{The Case of Tapajós (Pará, Brazil)}

Of our three cases, Brazil has the most elaborate set of laws and regulations for smallscale gold mining. In addition to national and federal laws, environmental regulations and the Pará state laws also define land use. On top of all that, there is a sophisticated customary miners' law. Conflicts in this case are not caused by the confrontation 
between a formal legal system and an informal, local or customary legal system, but instead between the federal Brazilian and Pará state legal systems.

The modern cycle of small-scale gold mining in the Brazilian Tapajós region, a tributary of the Amazon in the Southwestern part of the state of Pará, started in 1958 with the discovery of the first gold deposits. Migrant miners from other regions in Brazil, but also from neighbouring countries such as Guyana, moved into the region to explore and exploit the mineral-rich soil. The lack of state presence in the region gave the social actors involved in the gold extraction the liberty to auto-organise their own regulatory framework for the exploration and exploitation of the mineral resources. One of the bases of this unwritten miners' law is the social consensus that the property rights on land and the mineral resources it holds belong to the miner who has first discovered the gold deposit and started its exploration (Cleary 1990). Other miners are allowed to explore parts of a territory at the discretion of the mining area's owner, who usually charges a flat fee of $10 \%$ of the gold production.

Property rights are recognised in the sense that they can be bought and sold, and over time owners have registered their properties and acquired documentation. In addition to the regulation of property rights, the mining law also contains social norms regarding the work relations of the mining process. The work regime is known by the small-scale gold miners as sociedade (partnership), and means that the workers' remunerations are linked to the production of the mine (Mathis 1995: 9). The workers' part is generally $30 \%$ of the physical gold production, but this percentage is lower in the case of mechanical excavators or the use of crushers (both of which make the work less arduous). Although this working regime is not in accordance with the Brazilian working legislation, all parties involved consider the system to be fair. The fact that the worker has a share in the outcome of the extraction process creates a stabilising mechanism as the owner and the worker have the same interest in the production. The mining region of Tapajós was legalised 25 years after its discovery, in July 1983, when the Ministry of Mines and Energy created the Reserva Garimpeira, the Tapajós small-scale gold mining reserve.

The regulatory framework of mining in Brazil includes the Mining Code (Decree Law 227 of 28.02.1967) and legislation concerning environmental licensing procedures, but also specific devices that deal with small-scale mining and its regulations. The Mining Code defines all mineral deposits as an asset of the state, which has the right to grant licences for research through the Federal Mining Agency (DNPM Departamento Nacional de Produção Mineral) or grant the mining rights by the Ministry of Mines and Energy (MME). The code establishes different legal regimes for the exploitation of mineral resources. Small-scale mining is acknowledged as a viable economic sector. The Mining Code also provides the possibility of declaring certain areas for exclusive use by small-scale miners through the implementation of smallscale mining reserve areas, like the Reserva Garimpeira of Tapajós. The combination of formal legislation and miners' law was the basis for a small-scale mining economy and society where, at its height in the 1980s, 100,000 people found a living. Several mining camps developed into villages over time, and now places like Creporizão, Creporizinho, Cabaçal and Água Branca have schools, medical posts and a local police force.

From 1989 onwards, the pressure from the Federal and State governmental institutions grew and, through a series of regulations, small-scale gold mining became 
subjected to a mining permit (PLG) issued by the Pará state environmental agency after approval of the DNPM. It can be granted to either a Brazilian citizen on an individual basis or to cooperatives. The holder of a mining permit is held responsible for the environmental damages caused by mineral extraction, and must therefore be in the possession of an environmental licence (Sousa et al. 2011: 744). The introduction of the formal mining permit resulted in the formalisation and bureaucratisation of the miners' law agreements on the property of gold fields and access to mining grounds.

In 2005, a new federal government intervention limited the use of land alongside the main road that borders the Reserva Garimpeira, the BR 163. Although the objective of these measures was to avoid illegal timber logging, small-scale mining activities were affected because the federal government formally declared large parts of the Reserva Garimpeira as a protected area for nature conservation. The Reserva Garimpeira was, however, never cancelled, a reality that symbolises the discordant stances regarding mining in areas of conservation between different state representative bodies. Apart from nature conservation, there are also protected areas for the indigenous population in the region, where no mining permits are allocated. Nevertheless, in both the indigenous territories and areas reserved for nature conservation, small-scale mining is frequently practised without the proper licences. In the case of the indigenous territory, it is common for a local tribal community to allow garimpeiros to mine their land in exchange for $10 \%$ of the gold production. Such agreements follow the pattern of the miners' law, and continue to be the way to deal with the interests of different populations in the gold fields. The interventions of the state were incorporated in the existing legal system. In the case of nature reserves, enforcement of legislation by the Federal agencies is hindered by the sheer size of the territory and distance to the urban centres. From the point of view of the miners, they are still working in the Reserva Garimpeira, and as such they feel entitled to work there.

International prospector companies and mid-scale mining companies who gain access to the land and its minerals are the new players in Tapajós. These companies are equally affected by nature conservation policies at the expense of mining. However, they are better equipped to obtain the required permits from state agencies, including the environmental licences. Interestingly, they also comply with customary miners' law. The entrance of these companies in Tapajós generally occurs without conflict, because they respect the customary land property system. Prospecting firms give financial compensation for the land used, and in the event that economically viable deposits are discovered, the landowner will transfer his customary mining rights to the mining company. He will in turn receive a percentage of the gold production revenues. Economic difficulties faced by the owners of mining areas make them receptive to such offers. In the same line, medium-scale mining operations allow traditional small-scale miners to work on their property with a traditional working relations and payment-system. The relationships established in these new economic arrangements are based on the same principles as the customary agreements in miners' law.

Despite new legal frameworks, small-scale mining is still the main economic sector in the Tapajós Reserva Garimpeira. Approximately 20,000 miners currently work in the region and they produce about 20 to $30 \mathrm{~kg}$ of gold per day. The vast majority 
of these garimpeiros act in a "not legalised" way - which means they do not have permission from the National Mining Agency (DNPM) and proceed without license from the state environmental agency. This lack of legalisation is due in part to the DNPM protracted licensing process. More than 19,500 requests for permissions for small-scale mining in the Tapajós region await an administrative decision. In 2007, DNPM began to accelerate the processing of these permit applications. Recently (in February of 2010) the DNPM handed out 2,083 permits.

In addition, small-scale miners report other obstacles in obtaining the required licences. Distance is a problem faced by small-scale miners, as the offices of the Federal and State authorities are located in Itaituba, Santarém and Belém, at least a 1-, 2or 3-hour journey by plane respectively. Furthermore, miners must hire a geologist for the compulsory environmental impact study and plan for recovery of the mined area. Such requirements are very costly and time-consuming. As a result many people continue to work without all of the documents in place, sometimes even facing the risk of imprisonment or the confiscation of machinery and equipment. At the same time, however, proper enforcement of the law proves to be difficult for the responsible authorities.

\subsection{CONCLUSION}

Each of the three study sites in the small-scale gold mining regions has shown that people are creative agents when it comes to using and mixing, at times simultaneously, different legal systems. We have furthermore seen examples of how legal systems that exist together, engage with and thus influence each other. It helps us understand how mining cultures and efforts of authorities to manage conflicts surrounding small-scale mining work out. The engaged legal systems reveal conflicts between stakeholders at different levels, but also show how legal systems may engage with each other to avoid, mitigate or resolve conflicts. A comparative, deeper understanding of legal pluralism in small-scale gold mining allows for the development of mining policies that are relevant to miners and reflect the daily realities of small-scale gold miners. At present, state efforts to regulate small-scale gold mining are often confronted by resistance and incompliance on the part of miners. Likewise, customary rights are not only disrespected by authorities, but also by contenders of access to the gold rich soils. It is our contention that legal systems and related policies that incorporate customary rules, local law, and miners' law have greater chances of conflict solution. This conclusion is also drawn in other situations of legal pluralism, where researchers have, for example, found that it is a resource for the co-management of fisheries (Jentoft et al. 2009).

The three cases are different in scale and historical context. The Suriname case is specific due to its discussion of the confrontation between a small Maroon community and a large-scale mine (the only one in the country). The Colombia case stands out because the legal pluralism is part of the formal laws of the country, although in the local practice the jurisdictions of the different systems clash and have different weight in the decision-making processes of municipalities and Community Councils. The Brazilian case shows how a customary system, in this case the miners' law in Tapajós, is complemented by a whole series of formal regulations and laws. New 
conflicts arise because these formal regulations and laws do not only legitimise existing agreements, but also create new obstacles and internal contradictions.

The engagement between different legal systems is important in all three cases. A lack or inadequacy of national legislation gives rise to informal regulations and more authority to customary law. In Suriname, the important role of customary law can be attributed to the inadequacy of the Mining Law for small-scale mining, and its weak enforcement. Customary law of the Maroons is not recognised de jure, but in the part of the national territory where the small-scale gold miners work, it is respected and is the rule by which the access to the gold is organised. In Colombia, de jure legal pluralism exists through the recognition of the Afro-Colombian communities, including land rights (but not rights to the subsoil!). In relation to small-scale mining, however, the plural system causes confusion because the jurisdictions of the Community Councils and municipalities are not always respected. In Brazil, the mining and environmental laws are well developed, but in the Tapajós mining region customary miners' law continues to be the basis for many agreements, relationships and rules.

These differences become even more visible when we focus on the land rights and the construction of property. In all three case studies, we have seen that the right to the gold bearing location and its exploitation is very much defined by tribal or ethnic claims, and in the case of Brazil, the claimant who discovers the place and the gold. In Brazil, this traditional ownership is easily changed into official property, legitimised by federal state legislation. Maroons in Suriname do not have formal land rights, but the villagers of Nieuw Koffiekamp have been in a cat and mouse game with the government and the licensed large-scale companies for almost thirty years, because it is believed that relocation of the community will encounter much resistance. The Afro-Colombian communities present the only example of full de jure land rights, but in practice their collective decision-making power in relation to small-scale mining is jeopardised by municipal authorities and individual land owners.

Researching legal pluralism is essential in a project about conflicts in small-scale gold mining, because formalisation of the activity is often considered the first step to resolving the many social, economic and environmental conflicts that come with it. By formalisation we mean the acknowledgement of small-scale gold mining as an economic activity within the formal laws of a country, which ideally result in improved monitoring and governance of the sector. What can we conclude with respect to the effect of engaging legal systems on mining related conflicts? The only case where we actually see conflicts caused by the operation of different legal systems is Colombia. The Community Councils, municipal authorities, artisanal miners and mechanised miners make use of different sets of norms, which may clash and in turn result in social tensions. In Suriname, the informal respect for customary claims does not resolve the conflicting interests, but it does help to manage them. In both countries, formalisation of small-scale gold mining may contribute to the mitigation of some of the conflicts, especially if it entails a legal order where the specific character of the small-scale mining communities is addressed. In Brazil, the conflict is not between different systems of legality, but within the different and contradicting layers of state law. The legal orders create a complex system of demands, and the small-scale gold miners get trapped in the bureaucratic mill of the state. The case in the Tapajós region serves as a starting point for the discussion whether formalisation of small-scale gold mining really is the way to a conflict-free, sustainable economic activity. 


\section{REFERENCES}

Barreto, L. 2011. Analysis For Stakeholders on Formalization in the Artisanal and Small-Scale Gold Mining Sector Based on Experiences in Latin America, Africa, and Asia. Medellin: Alliance for Responsible Mining (ARM).

Benda-Beckmann, F. von, K. von Benda-Beckmann, and J. Spiertz. 1998. Equity and legal pluralism: Taking customary law into account in natural resource policies. In Searching for Equity: Conceptions of Justice and Equity in Peasant Irrigation., ed. R. Boelens, and G. Dávila, 57-69. Assen: Van Gorcum.

Benda-Beckmann, von F. 2002. Who's Afraid of Legal Pluralism? Journal of Legal Pluralism 47: 37-82.

Benda-Beckmann, von F. 2001. Legal pluralism and social justice in economic and political development. IDS Bulletin 32, no. 1: 46-56.

Brana-Shute, G., C. Healy, A. Edgardo, and C. Reis. 2001. Peace and democracy in Suriname. Final report of the special mission to Suriname (1992-2000). Organization of American States. Unit for the Promotion of Democracy.

Cleary, D. 1990. Anatomy of the Amazon gold rush. Iowa City: University of Iowa Press.

Commissie voor Nieuw Koffiekamp. 1996. Verslag aan de Minister van Natuurlijke Hulpbronnen en Granman Aboikoni, 10 juli 1996.

Couso, J., A. Huneeus, and R. Sieder. 2010. Cultures of legality: Judicialization and political activism in Latin America. Cambridge: Cambridge University Press.

Defensoría del Pueblo Colombia. 2010. La minería de hecho en Colombia. Bogota, Colombia.

Griffiths, J. 1986. What is legal pluralism? Journal of Legal Pluralism 24: 1-55.

Hammond, D. S., V. Gond, B. de Thoisy, P. Forget and B. de Dijn. 2007. Causes and consequences of a tropical forest gold rust in the Guiana Shield, South America. Ambio 36, no. 8: 661-70.

Healy, C. 1996. Natural resources, foreign concessions and land rights: A report on the village of Nieuw Koffiekamp. Paramaribo: Organization of American States (OAS), Special Mission to Suriname, Unit for the Promotion of Democracy.

Heemskerk, M., and R. van der Kooye. 2003. Challenges to sustainable small-scale mine development in Suriname. In The socioeconomic impacts of artisanal and small-scale mining in development countries, ed. G. Hilson, 661-678. Leiden: A.A. Balkema.

Hoekema, A. J. 2005. European legal encounters between minority and majority culture: Cases of interlegality. Journal of Legal Pluralism 51: 1-28.

ICMM, CASM, and CommDev. 2010. Working together. How large-scale mining can engage with artisanal and small-scale miners. Washington: IFC, World Bank.

Jentoft, S., M. Bavinck, D. Johnson, and K. Thomson. 2009. Fisheries Co-Management and Legal Pluralism: How an Analytical Problem Becomes an Institutional One. Human Organization 68, no. 1: 27-38.

Lugo, J. P. V. 2006. La jurisprudencia como campo de reflexión de la diversidad cultural: Apropiación jurídica de nociones culturales. Universitas Humanística 62: 205-38.

Mathis, A. 1995. Garimpos de ouro na Amazônia: Atores sociais, relações de trabalho e condições de vida. Papers do NAEA 37. http://www.ufpa.br/naea/novosite/paper/78.

Meinzen-Dick, R. S. and R. Pradhan. 2001. Implications of legal pluralism for natural resource management. IDS Bulletin 32, no. 4: 10-7.

Moore, S. F. 1978. Law as process: An anthropological approach. London, Henley and Boston: Routledge \& Kegan Paul.

Moore, S. F. 1973. Law and social change: The semi-autonomous social field as an appropriate subject of study. Law \& Society Review 7, no. 4: 719-46.

Simon Thomas, M. 2009. Legal pluralism and interlegality in Ecuador. The La Cocha murder case. Cuadernos del Cedla Vol. 24. Amsterdam: Centre for Latin American Research and Documentation. 
Simon Thomas, M. 2012. Forum Shopping. The Daily Practice of Legal Pluralism in Ecuador. In Andeans and Their Use of Cultural Resources. Space, Gender, Rights \& Identity, ed. A. Ouweneel. Cuadernos del Cedla Vol. 25. Amsterdam: Centre for Latin American Research and Documentation.

Sousa, R., M. Veiga, D. van Zyl, K. Telmer, S. Siegel, and J. Selder. 2011. Policies and regulations for Brazil's artisanal gold mining sector: Analysis and recommendations. Journal of Cleaner Production 19: 742-50.

Spiegel, S.J., and M.M. Veiga. 2007. Report on the policy and governance initiative. Enhancing multi-stakeholder approaches to address mercury, small-scale gold mining and the institutional dynamics of change. Viena: UNIDO/ UNDP.

Theije, M. de, and M. Heemskerk. 2009. Moving frontiers in the Amazon: Brazilian small-scale gold miners in Suriname. European Review of Latin American and Caribbean Studies 87: 5-25.

Tschakert, Petra. 2009. Recognizing and nurturing artisanal mining as a viable livelihood. Resources Policy 34: 24-31.

Van Schendel, W., and I. Abraham. 2005. Illicit flows and criminal things: States, borders, and the other side of globalization. Bloomington: Indiana University Press. 


\title{
Theorizing participatory governance in contexts of legal pluralism - a conceptual reconnaissance of fishing conflicts and their resolution
}

\author{
Maarten Bavinck', Merle Sowman ${ }^{2}$ \& Ajit Menon ${ }^{3}$
}

\begin{abstract}
Many coastal fisheries, including those of South Asia and South Africa, are characterised by high levels of social conflict, environmental deterioration and fragmented governance. The REINCORPFISH research project analyses the conflicts occurring in the fisheries of these two regions and promotes a governance process that recognises the existence of (a) multiple actors, and (b) legal pluralism. More importantly, it strives to further a governance style that does justice to fisher interests and builds from the bottom up. The present chapter provides a conceptual framework for analyzing such processes within the context of interactive governance theory (Kooiman 2003; Kooiman et al. 2005). The starting point is the perspective of collective action that explains why and how individuals and groups, who rely heavily on specific natural resources, develop autonomous institutions for their management. Legal pluralism and political ecology theories provide tools for analyzing the roles and conflicting interests of other institutional actors, such as state agencies, in resource management, and the positive and negative - interactions between various legal systems. The resulting framework is applied to investigate and compare the nature of fishery conflicts across the two regions and identify, from a theoretical perspective, the bottlenecks and chances for effective, participatory governance.
\end{abstract}

Keywords Conflict, governance, legal pluralism, South Asia, South Africa, fisheries.

\section{I INTRODUCTION}

This chapter, which deals with capture fisheries in the South, has two starting points: the notion (1) that fisheries conflicts in the current age are substantially different than in the past, and (2) that such conflicts are as much about fisheries as they are about the governance frameworks that act upon them. It stresses the perspectives of fishery underdogs - the populations of small-scale fishers who inhabit the coastal zones of Asia, Africa, Latin America and some parts of the North. Small-scale fisheries are contrasted with large-scale, industrialised fisheries. Points of departure are the increasing value of

\footnotetext{
${ }^{1}$ Associate Professor, University of Amsterdam, Netherlands (Corresponding author: J.M. Bavinck@uva.nl).

${ }^{2}$ Associate Professor, University of Cape Town, South Africa.

${ }^{3}$ Associate Professor, Madras Institute of Development Studies, Chennai, India.
} 
seafood products on the one hand, and the ongoing deterioration of marine resources on the other, both of which are held to increase the chances of conflict occurring. We will argue that conflict reduction is likely to coincide with the integration of a governance framework and its upturning. We suggest that the result - participatory governance of a particular variety - will have greater chances of being legitimate, defusing strife and achieving environmental sustainability.

This chapter examines two regions of contemporary fishery conflict - one in South Asia and the other in South Africa - in a historical and comparative perspective. This study is the focus of a new research and action project funded by the Netherlands Organisation for Scientific Research (NWO) and the Dutch Ministry of Foreign Affairs. ${ }^{4}$ We presume that the conditions that pertain to these two geographical regions are at least to some degree generalisable to other parts of the world.

The first section below provides the main elements of our theoretical perspective, highlighting inputs from interactive governance, legal pluralism and political ecology. We leave collective action theory, which explains the genesis of fisher law before the advent of industrialisation, market globalisation and state involvement, to Section 3. Use is also made of the notions of endogenous versus exogenous, and symmetrical versus asymmetrical conflict developed by Rapoport (1974).

Our historical perspective is stylised and ideal-typical. It builds upon Max Weber's conception of the term 'ideal type' as a conceptual tool to facilitate comparisons between societal phenomena. As Gerth and Mills point out, Weber "felt that social scientists had the choice of using logically controlled and unambiguous conceptions, which are thus more removed from historical reality, or of using less precise concepts, which are more closely geared to the empirical world" (1948: 59-60). Following from his interest in global comparisons, he chose to consider 'pure cases', constructed as ideal types. It is important to realise that, despite their exaggerated nature, ideal types have a sound base in reality. Rather than replicating the details of each particular manifestation of a societal phenomenon, ideal types "serve as guides in a filing system" (Weber 1954: xxxviii) - they are distilled images constructed for analytical purposes. In Section 4 the chapter moves on to investigate the impact of a century of fisheries modernisation, ${ }^{5}$ both in the practice as well as the governance of fishing. Modernisation is coupled with the entry of new fishing interests, as well as new contenders for coastal and marine resources. These developments are paralleled by the advent of new governing actors, such as state governments and international organisations, and new bodies of hard and soft law (Birnie and Boyle 2002), which often have a broader perspective than fishing alone. The end result is a bundle of novel fishing problems and a complex condition of legal pluralism, where fishing is governed from various non-integrated loci of authority at different scale levels. The shift of power

\footnotetext{
${ }^{4}$ The project entitled 'Reincorporating the excluded: providing space for small-scale fishers in the sustainable development of fisheries of South Africa and South Asia' (acronym REINCORPFISH) commenced in 2010 and will continue until 2015.

${ }^{5}$ For the purpose of this chapter we distinguish two major types: small-scale and industrial fisheries. We associate small-scale fisheries with "the most labor intensive, technically simple, and low-cost fishing methods" (Johnson et al. 2005:79), while industrial fisheries generally have converse characteristics. Johnson (2006) and Johnson et al. (2005) present a thoughtful analysis of these categories and the intermediate fisheries types that are emerging.
} 
from fishing communities to more distant governors is argued to have resulted in the marginalisation of small-scale fishers and the exacerbation of conflict.

Subsequent sections explore and provide a comparative analysis of the present condition of conflict and governance in South Asia and South Africa and offer proposals for the ways forward, notwithstanding the political ecology constraints that might obstruct change.

\subsection{A THEORETICAL PERSPECTIVE ON CONFLICT AND ITS RESOLUTION}

We define fishing conflicts broadly as confrontations between groups or categories of people regarding fishing activity and its management. As capture fishing takes place in a common pool resource, users may disagree over the use of sea and coastal space, or over allocation (who takes what fish). More indirectly, disagreements may focus on marketing (as changes in supply often result in changes in landing prices), fishing technology (which is considered harmful to the marine environment, and/or to other users) and on rules that govern the fishery.

Interactive governance theory locates fishing conflicts in three realms: the Systemto-be Governed (SG), the Governing System (GS) and Governing Interactions (GI). In the case of primary sector activities, a SG consists of a natural sub-system (the marine ecosystem) and a social sub-system (the social organisation of fishing, processing and marketing) that are linked through the act of fishing. Governance is the "whole of public as well as private interactions taken to solve societal problems and create societal opportunities" (Kooiman and Bavinck 2005:17), and is exercised through GS and GI. Needless to say, every SG has some kind of GS (although the GS is not necessarily complete, legitimate or effective), and the latter may be governmental or non-governmental (market, civil society) in nature. The nature of the interactions between the GS and SG co-determine the governability of the system and it is within these interactions that conflict can be acute. These interactions take on different forms, or modes. Kooiman (2003) distinguishes between three ideal-typical modes of governing: self-governance, hierarchical governance and co-governance. We return to the latter mode - co-governance - that is particularly relevant to our topic below.

Although conflicts frequently centre on physical interferences between two individuals or groups of people, they arise for various reasons, including demographic changes, inequitable power relations, competition over natural resources, changing government priorities, structural injustices and institutional failure (Bennett et al. 2001). Research from several cases, however, suggests that conflict is frequently rooted in ideas of entitlement (Bavinck 2005). This takes us to the GS-level, where varying ideas of rights exist. The critical questions are: Does this person have the right to fish here in this particular manner? Who decides who can gain access to the fishery and what criteria are used to guide such decisions? Different ideas about rights thus also become a locus of conflict. Rights may take the form of norms and conventions, or of working rules (Bromley 2006). A body of such regulations, for which we apply the term law, constitutes a legal system. In terms of interactive governance theory, legal systems belong to the steering mechanism, or GS. Weber (1954) recognised, however, that to make law work, one also needs 'a staff of people': the law-makers, the enforcers 
and the arbiters (see also Pospisil 1971; Bavinck and Woodman 2009). The latter are the 'governors' of the societal system at hand - those who interact to 'solve societal problems and create societal opportunities'.

Legal pluralism is a condition that applies when various legal systems are applicable to an identical situation (Vanderlinden 1972), such as a disagreement regarding fishing practice. Power differentials play an important role in deciding the outcome of such differences. For example, in situations where business elites are supported by the state, their collaboration may favor a set of rules that maintains the status quo. Referring again to Weber, we define power in the limited sense of "the possibility of imposing one's will upon the behavior of other persons" (1954: 323). Domination is the condition by which one legal system overrules another or assumes a privileged status in practice. ${ }^{6}$ We will argue below that participatory governance is concerned with reversing patterns of domination, and increasing the power of primary stakeholders the fishers - over the governance process.

Figure 9.1 refers to three ideal-typical legal systems, coinciding with local, national and international scale levels. Real life situations of course vary from this simplistic schema. We have also numbered the legal systems in the sequence in which they have generally arisen, starting from local and moving to national and international. The assumption is that local law frequently remains more important than national and international law (although here too there may be differences).

We made reference above to power and domination shaping the way in which particular legal systems are prioritised and often imposed on others. Understanding why particular legal systems are privileged, however, requires examining how priorities with regard to resource allocation are determined. Political ecology emphasises that the allocation of fisheries resources is determined in the realm of politics and that actors with more political and economic power are able to shape policy choices. We shall see below that in the case of both South Africa and South Asia, the movement toward a more commercially-driven fisheries was because these fisheries, often supported by the state, were able to impose their writ on small-scale fishers. The other dimension of political ecology of importance is its focus on how the allocation of resources affects different people unequally; in our cases the small-scale fishers are adversely affected by more commercialised fisheries.

What political ecology does is suggest that inequalities within society might hamper initiatives that aim at improving the sustainability (ecological, socio-cultural and economic) of the SG. Particular fishers might not want to change the GS because the present system supports their interests. However, political ecology also recognises that people contest systems that undermine their livelihoods and customary rights, and that spaces may be created to do so. The challenge is therefore to find such spaces or opportunities (Isaacs 2003; Ribot 2004).

\footnotetext{
${ }^{6}$ Weber (1954:328) defines domination as: the situation in which: the manifested will (command) of the ruler or rulers is meant to influence the conduct of one or more others (the ruled) and actually does influence it in such a way that their conduct to a socially relevant degree occurs as if the ruled had made the content of the command the maxim of their conduct for its very own sake. Looked upon from the other end, this situation will be called obedience" (italics in the original).
} 
This brings us to the notion of participatory governance, or, in the parlance of interactive governance, the co-governance mode. Participatory governance is commonly founded on the principle that people have the right to participate in decisions that affect their lives. This principle is advocated in a number of international policy instruments that have been adopted by various governments worldwide (e.g., Principle 10 of the Rio Declaration, 1992; the Convention on Biodiversity, 1992; WSSD, Johannesburg Plan of Implementation, 2002; the Aarhus Convention, 2001). These calls for participation have led to experimentation with various forms of resource management that involve users in decisions and management actions, thereby shifting the locus of power from the 'governors' to a more equitable power-sharing relationship (Jentoft and McCay 1995; Pomeroy and Carlos 1997; Berkes et al. 2001; Hauck and Sowman 2003; McConney et al. 2003; McClanahan and Castilla, 2007; Pinkerton 2009). A key focus of such governance approaches the establishment of appropriate institutional arrangements to manage such socio-ecological systems, including putting in place procedures to resolve conflicts, negotiate compromises and build consensus (Charles 2007; Jentoft 2007; McClanahan et al. 2009; Pinkerton 2009). Increasingly, evidence from research on participatory forms of governance suggests that such approaches are more likely than top-down, technocratic approaches to lead to sustainable outcomes (Pomeroy 1995; Hauck and Sowman 2003; Defoe and Castilla 2005; Kooiman et al. 2005; McCalanahan and Castilla 2007). However, determining the most appropriate mode of governance - who should participate, when and how such participation should take place, and what level of involvement would be most appropriate - depends on a variety of factors, not least of which is the capacity at the local level to take on governance functions.

\subsection{COLLECTIVE ACTION AND THE ORIGIN OF FISHING LAW}

Fishing is one of the world's oldest occupations, having developed in many coastal zones in the era that human societies relied heavily on hunting and gathering. As early fishers depended on opportunities provided by their immediate environments, they evolved different fishing technologies and practices. Von Brandt's (1984) Fish Catching Methods of the World - a standard work for those interested in the vocation - testifies to the breadth of human ingenuity as it has evolved over the ages.

Until a century ago, fisheries in most parts of the world, although integrated into markets, were geographically, economically and politically marginal to the rest of society. This might well have been a mutual kind of arrangement - whereas seafood was seldom crucial to society and states generally had little interest in the people who carried out the profession, fishers themselves may well have practiced 'the art of not being governed'. 7

\footnotetext{
${ }^{7}$ This is the title of a influential book by the political scientist and anthropologist James Scott on the tribal population of Southeast Asia. Scott (2009) suggests that fisher peoples have often practiced the same 'art'.
} 
How then were such fisheries originally regulated? Being marginal, governments if they existed - generally evinced little interest, ${ }^{8}$ and fishers had to regulate themselves, if at all. This, however, is probably what they had being doing from the start. After all, as Benda-Beckmann note, "resource allocation is never unstructured because continuity in the production of basic goods is never unimportant" (1995: 1; Dalton 1967). As fishing carried out on a regular basis produced the 'basic goods' necessary for immediate sustenance or for trade, we may assume that fisher societies developed their own rules for proper behavior, as well as ways to implement them. ${ }^{9}$ Economics in rural societies never being completely separated from other spheres such as family, religion, and politics, meant that fishing regulations became part of more comprehensive yet monoistic legal systems, presided over by traditional authorities who - unlike most outsiders - were knowledgeable of the intricacies of the profession. In terms of interactive governance theory, this generally amounted to self-governance.

Collective action theory (Ostrom 1990; 2007), which has drawn attention to the fact that users of common pool resources will, under certain conditions, develop appropriate management arrangements, lends support to the view of self-governance. Proponents of the collective action approach have made substantial effort to determine the circumstances under which this may or may not arise, and how such ventures can be suitably nested. Evidence of collective action in resource management has been found in contemporary fisheries systems around the world (Kurien 1987; Ruddle and Satria 2010). Anthropologists have also 'discovered' social strictures that are not covered by the term resource management as it is commonly understood, but do act to regulate fisher's lives. These include, for example, the taboos that often prevail in fishing societies (Malinowski 1992; Van Ginkel 1987; Colding and Folke 2000; Cinner and Aswani, 2007).

How do conflicts over fishing manifest themselves in self-governed societies such as the one described above? Rapoport's (1974) taxonomy, which distinguishes endogenous from exogenous conflict, is a useful pointer. Endogenous conflicts are those wherein the conflicting units "are part of a larger system that has its own mechanisms for maintaining a steady state, which may include mechanisms for controlling or resolving conflict” between the units (Rapopport 1974: 175). To clarify, Rapoport (1974) provides the example of a state in which two citizens conflict. The state (the larger system) has means to prevent the conflict from exceeding certain bounds (such as through the application of force) and institutions to resolve the conflict (courts, etc.). Exogenous conflicts, on the other hand, take place between units that belong to different systems and lack a joint facility for control or resolution. Following this line of thought, Bavinck (2011b), writing about the fishing wars that occur between fishers of two neighboring states of India, concludes that conflicts which involve people within the boundaries of the self-governing fisher system are better contained and addressed than those that involve parties from different institutional systems, where there are no joint mechanisms for conflict resolution within its boundaries. The latter type of conflicts are potentially more explosive and possibly of longer duration.

\footnotetext{
${ }^{8}$ Here again there are exceptions, such as for high value sea products such as pearls, chanks etc. ${ }^{9}$ Anthropological studies of primitive societies in which fishing plays an important economic role testify to the regulated nature of such activity (e.g. Malinowski 1922; Radcliffe-Brown 1922; Firth 1946).
} 
We return to Rapoport's (1974) taxonomy in the next section that deals with the consequences of the industrial revolution in fishing. We also draw attention to a second distinction, symmetrical and asymmetrical conflict.

\subsection{INDUSTRIALISATION, GLOBALISATION AND THE REFASHIONING OF GOVERNANCE}

The isolated and relatively small-scale fisheries of the pre-industrial world changed dramatically in the 20th century through processes internal and external to the fisheries. The latter was caused by the rise of new interests in the coastal and inshore zone as the result of urbanisation, industrial development, mineral exploitation, coastal tourism and environmental conservation, to name but a few (Cicin-Sain and Knecht 1998). These interests created new claims to coastal space and resources that impinged on fishing interests. Nevertheless, it is the former that constitute the focus of this chapter.

Industrialisation and globalisation affected capture fisheries internally (Platteau 1989; Thorpe and Bennett 2001; Bavinck 2011a). Phase 1 commenced late in the 19th century and was centered in Europe, North America, Japan and, to an extent, South Africa (Croeser et al. 2006). Post-colonial governments were among those initiating phase 2 in the South, mainly in the period after WWII. The technology in both phases was identical, and consisted of engine-driven harvesting technology, new gear types, refrigeration and large-scale infrastructure (such as harbours). Markets developed alongside increases in production, with most landing sites currently connected to national and international markets. Seafood now constitutes one of the world's most traded agricultural commodities (World Bank 2008).

The absolute increase in wealth that occurred in tandem with the industrialisation of fisheries is indicated first of all by the growth of overall fish production. FAO figures suggest that global fish catches (inland and marine) increased four and a half times in the period 1950-2008 from 20 to 90 million metric tonnes (FAO 2011). In the North, this growth had of course set in much earlier. McEvoy (1986: 126) estimates that while the California's fishing population remained roughly stable between 1899 and 1925 , catch in this state increased tenfold.

Production increases are not necessarily accompanied by increasing income, but here again the figures are revealing. Delgado et al. (2003) suggest that increases in world production in the period since WWII were paralleled by rising consumer demand and a long and virtually uninterrupted increase of prices. Confirming this trend, the World Bank (2008:8, figure 8) calculates that the real export unit value (US\$/tonne) of fishery products in the world more than doubled between 1976 and 2004.

The net result of these developments has been, to make use of Butcher's (2004) terminology, a 'great fish race' and the pushing back of the oceanic wilderness (cf. Smith 1994; 2000). For many capture fishers who tapped into world markets and were able to upgrade their activities, this has brought about a 'golden age'. As is to be expected, this has not been true for all: the distribution of economic benefits from fishing is severely skewed, and poverty occurs next to riches (Eide et al. 2011).

One of the clear manifestations of varying opportunities is found in countries of the South, where a division between modern and small-scale fishing fleets has led to many conflicts between them (Platteau 1989; Bavinck 2005). These conflicts arise because of 
the competition for similar resources, technical interferences (the operation of active and passive gears in the same sea space) and increasing state support for industry at the expense of developing small-scale fisheries (McGoodwin 1987; Platteau, 1989; FAO 2003). The steady deterioration of fish stocks and marine environments acts to exacerbate such conflicts of interest.

The manifold changes in and around the fisheries precipitated new governance arrangements. As fisheries became worthy of attention, they drew in outside investors with their own perspectives of rights and regulations. Governments claimed coastal territory, capitalised on fisheries development, and drew up modernisation plans and regulatory legislation. In recent decades, there has also been a flurry of international effort to curb unwanted fishing practice. The end result of which has been the integration of the marginal fisheries of the past into a widening governance framework consisting of multiple layers and different societal origins.

What have all these changes meant for the incidence and character of fishing conflicts? In comparison with the pre-industrial era, we argue that conflicts in the SG have intensified (as the economic stakes have become higher and resources decline), widened (with hitherto distinct fisher groups now meeting on the same fishing grounds), and expanded (with the rise of competing interests). Furthermore, where the state has supported the growth of industry at the expense of the small-scale sector, interactions between SG and GS have become more conflictual.

The development of legal pluralism too has impacted on the manifestation of conflict. Following Rapoport's (1974) distinction introduced earlier, we argue that endogenous conflict has frequently been replaced by exogenous conflict between parties adhering to different legal systems. In some contexts, the expansion and increasing economic and political power of the industrial sector has relegated the small-scale fisheries sector to the margins and fueled 'illegal' fishing activities. However, for these now marginal fishers and fishing communities, harvesting resources is not only a means of livelihood, but also an element of cultural identity. Thus the ongoing harvesting of resources in spite of the imposition of formal rules is considered legitimate in terms of customary systems (Jentoft and McCay 2003; Cinner and Aswani 2007; Hauck 2011). This has consequences for the intensity and duration of fishing conflicts, as well as their resolvability. After all, as Jentoft et al. argue: "the stronger the pluralism, the greater the information problem, the greater the problems of enforcement, and the more likely the violation of rules" (2009: 29).

The development of legal pluralism also coincides with another dimension discussed by Rapoport - the difference between symmetrical and asymmetrical conflict. Symmetrical conflicts include opponents of comparable weight, while asymmetrical conflicts juxtapose parties that "may be widely disparate or may perceive each other in different ways" (1974: 176). Our analysis of longer-term trends in the fisheries suggests that asymmetrical conflicts have generally increased. This is true first of all in the SG, which has diversified in terms of capacity and strength. Small-scale fishers now ply the same fishing grounds as fishers on board semi-industrial trawlers and modern factory ships, and the conflicts between them are highly unequal in nature. Within the GS asymmetry has too come about, with national and international governing actors and institutions gaining weight at the expense of local governing systems. This shift has coincided with the removal of the centers of governing activity away from the coasts and the fishers themselves to centralised locations, where fishing interests also 
have to be balanced against other concerns. Far more than in the past, fisheries are now steered from city offices, by people who often have little notion of the practice of fishing and of the socio-cultural dimensions that are embedded in these lifestyles.

The following sections illustrate the changes that have taken place in world fisheries, and the intractability of fishing conflicts in contexts of legal pluralism and asymmetrical power equations. The cases from South Asia and South Africa also indicate ways forward. These are to be found in the bridging of legal pluralism and in a reduction of asymmetry, i.e. a re-devolution of authority to the fisher level.

\subsection{SOUTH ASIA (PALK BAY)}

South Asia has a rich and old fishing tradition. There are a variety of specialised fishing castes and fishing techniques, and a large marine fishing population spread out along its coastlines (Bavinck et al. 2013). The Palk Bay, which adjoins the coast of southeast India and northwest Sri Lanka, is a case in point. It is a shallow and circumscribed sea known for its biodiversity and rich fishing grounds, and bordered on both sides by a string of old trading (and smuggling) posts and fishing settlements (Venkataraman 2004). The fishing population shares a language (Tamil) and a history of interaction (Suryanarayan 2009).

Our knowledge of the pre-industrial era of fishing in the Palk Bay, which roughly coincides with the Independence of India (1947) and Sri Lanka ${ }^{10}$ (1947), is still patchy. Our present knowledge is as follows. On the Indian side, at the time of Independence, the kingdoms of Pudukottai and Ramnad had been integrated into the colonial administration. The region was isolated and quite marginal to the economy and politics of the nation, and infrastructure was generally lacking. The only fisheries of some consequence - situated more in the adjacent Gulf of Mannar than in the Palk Bay - were those for pearl and chank (Hornell 1950; Roche 1984; Bayly 1989). These seasonal fisheries were connected to particular locations and involved limited numbers of people. Due to their economic value, however, they were strictly regulated by the colonial government under the Indian Fisheries Act of 1897. Other fisheries - including the beachseine fishery that took place in locations where sandy beaches were available, particularly in the vicinity of the temple town Rameswaram - were probably regulated according to fisher law. The fishing population - constricted by limited local markets, bad transport facilities and limited means for preserving catches ${ }^{11}$ - was low in number and of varying castes and religions. Caste and religious councils played an important role in the regulation of societal affairs at the local level, including the mediation and regulation of fishing conflicts. These probably revolved largely around the use of fishing techniques and fisher migration.

\footnotetext{
${ }^{10}$ Sri Lanka was earlier known as Ceylon. The name change to Sri Lanka took place in 1972. We consistently refer to Sri Lanka irrespective of the historical period, in order to avoid confusion for the reader.

${ }^{11}$ The colonial government - aiming to maximize tax revenues - also took charge of salt production. In the absence of cooling technology, salt was an important ingredient for the preservation and thus trade of fish over longer distances.
} 
A broadly similar pattern pertained in pre-industrial fisheries along the northwest coast of Sri Lanka. At the time, the Jaffna peninsula was already well populated, offering a local market as well as transport opportunities to Colombo. The same was true for Mannar Island, which constituted a throughway for Indian labourers working in the plantation sector of central Sri Lanka. The long stretch of coastline between these two points, however, was covered with jungles and therefore sparsely inhabited. Beachseining took place in suitable locations and the plots, or paadu, were assigned by government. ${ }^{12}$ As in India, however, the colonial government seems to have displayed little interest in marine fishing - with the exception of the pearl fishery - leaving the majority of practices to fishers themselves to regulate.

Following Independence, the governments of India and Sri Lanka both launched extensive modernisation programs for the marine fisheries (Amarasinghe 2005; Bavinck and Johnson 2008). The main ingredients hereof in Sri Lanka were new technologies for fishing - outboard engines, nylon nets, and inboard engine boats ( 3.5 ton boats/multi-day craft) for driftnet fishing and longlining - as well as preservation (cooling/freezing). The same technological mixes found their way to Indian fishers along the Palk Bay, with one crucial difference: whereas the Indian government explicitly sought to promote trawling for fish in coastal waters, the Sri Lankan government promoted passive fishing methods, such as gillnetting. This different emphasis has had major implications for fisheries conflict in the Palk Bay.

The modernisation drive was remarkably successful: in both countries the level of catches rose leaps and bounds. The integration of seafood producing regions, such as the Palk Bay, into national and international markets also resulted in higher beach-level prices, which generally increased the attractiveness of fishing. Immigration therefore occurred along both coastlines, increasing population pressure (Bavinck 2011c).

The civil war, which commenced in Sri Lanka in 1983 and terminated only a quarter century later in 2009, severely impacted the fisheries in northern Sri Lanka. Not only was the shoreline depopulated, but security regulations often brought fishing to a standstill. It was only with the cessation of the war and the lifting of some control measures that regular fishing activity commenced once more. However, Sri Lankan small-scale fishers are now troubled by Indian trawlers that ply the inshore waters of northern Sri Lanka in search of shrimp and sea cucumbers (Sathyapalan et al. 2007; Scholtens et al. 2012). The incursions by Indian trawlers have resulted in an ongoing series of conflicts at sea in which Indian boats have been captured and crewmembers allegedly killed. On the other hand, Sri Lankan fishers have suffered heavy losses to equipment and livelihoods.

The 'fishing war' that is currently taking place is a complex phenomenon. It is clear, however, that it would not have achieved this intensity were it not for the integration of fisheries into the global market, and the economic value seafood products have come to represent. New technologies - such as trawling - have brought about new risks for gear interferences, such as trawlers cutting the nets of small-scale fishers. The perceived decline of marine resources as a consequence of fishing has given the conflict a particularly bitter flavor.

\footnotetext{
${ }^{12}$ Other than in southern Sri Lanka, where beachseining was organized at a community level (Alexander 1982), the beachseine fisheries of the north were generally owned by single families who employed wage labour (Bavinck 1984; Stirrat 1988)
} 
The current conflict over fishing in the Palk Bay cannot be satisfactorily understood with reference only to newly developing economic competitions and environmental declines. As was argued in Sections 2 and 3 above, fragmented and asymmetrical governance frameworks too make a substantial contribution to conflict. Legal pluralism has become a major factor in the Palk Bay, precipitating a shift in the nature of strife - in Rapoport's (1974) language - from endogenous to exogenous, and from symmetrical to asymmetrical.

In the decades following Independence, the governments on both sides of the bay have manifested themselves as claimants over marine territory and the human uses to which it is put. India and Sri Lanka have also entered into talks to redefine the maritime boundary between them. The 1974 Maritime Boundary Agreement established the geographical coordinates hereof, with India 'ceding' the small island of Kachchativu to Sri Lanka (Suryanarayan 2005). On the Sri Lankan side, the national government assumed the prerogative over inshore fisheries, whereas in India it was the state government of Tamil Nadu. Both governments have been engaged in developing bodies of fishing law which are distinct, and differentially rooted, from fisher law. Fisheries departments take charge of their enforcement.

The national governments on both sides, however, are in charge of defense and foreign affairs. With fishers being regarded as potential saboteurs and smugglers, interests other than fishing have come to play a role in the fisheries of the Palk Bay. The navy and the coast guard, in particular, occupy key positions. As part of their control over coastal and marine activities, these agencies - independently or via their respective Fisheries Departments - have implemented elaborate systems of personal identification and craft registration. One obvious distinction is that of Indian or Sri Lankan citizenship. Each is linked to a specific geographical territory on either side of the maritime boundary. Transgressions of the boundary are in principle not permitted.

As a consequence of the natural movements of fish, fishers in South Asia have never been as concerned about territorial boundaries as governments have (Bavinck 2001). Rather, the working rule in fisher society has been one of reciprocal access to fishing grounds, provided migrants (those coming from outside) follow the rules imposed by locals (those regarded as local right holders). From this perspective, national citizenship is not an issue - there is thus substantial evidence of the historical movement of fishers back and forth across the Palk Bay, making use of broadly accepted ideas of rights and responsibilities. In the event of violations or contested behavior, leaders of the fishing parties in question would act to find a mutually acceptable solution. Conflicts of this kind were therefore endogenous to the social group and their legal system.

As in other parts of the world, however, the introduction of trawling has created a new situation (Bavinck 2005). Trawl fishers have generally not been accepted as legitimate entrants to customary fishing grounds, in part because of the vast superiority of their technology. Rather than subscribing to the tenets of traditional fishing law, which, while emphasizing reciprocal access, recognises territorial rights, trawl fishers in South Asia have also established their own organisations and made their own rules for fishing. These emphasise a regime of complete open access that contrasts sharply with the notion of reciprocal access under specific conditions. The fishing wars that have taken place in India between the emergent class of trawl fishers and the many small-scale fishers has resulted in a variety of forms of accommodation across legal systems. Government agencies played an important role in whatever arrangements 
came about. The most important arrangement to have been realised on the Indian side of the Palk Bay is the so-called '3- and 4-day rule', which divides the days of the week between small-scale and trawl fishers (Bavinck 2003). This rule, which was drawn up by the civil administration for the protection of law and order, is not to any fisher party's complete satisfaction, but accepted nonetheless. It is maintained through a rare joining of governance forces on the Indian side, which includes civil administration, navy, coastguard, fisheries department, and the organisations representing small-scale and trawl fishers. The implementation of the ' 3 - and 4-day rule' has not resolved conflicts between the two sub-sectors completely, however. Substantial strife continues to take place in Indian waters on the days that trawling is permitted. As Indian trawl fishers are particularly active on the Sri Lankan side of the Palk Bay, small-scale fishing there is particularly affected. Many small-scale fishers in northern Sri Lanka currently refrain from fishing at all on days in which Indian trawlers are known to arrive, and protests - including petitions to the Indian authorities and occasional boat captures are mounting (Scholtens et al. 2012).

\subsection{SOUTH AFRICA}

South Africa's coastal environment is a highly productive, diverse and dynamic system that provides food and livelihoods for thousands of coastal dwellers and supports a thriving industrial sector, mainly in the south western region of the country. Extending from the Namibian border in the north west of the country to Kosi Bay in the east, this $3000 \mathrm{~km}$ coastline is flanked by the cold, nutrient-rich waters of the Benguela current on the west coast and the warm nutrient-poor waters of the Agulhas current on the east coast. Similar to the Palk Bay region, relatively little is known about the fishing activities of indigenous inhabitants prior to the industrialisation of the fishing industry by British colonists in the early 1890s. Archival records suggest that the early indigenous people of these coastal regions were largely nomadic pastoralists and herders, who also engaged in shore-based harvesting of shell-fish and certain line fish species (Parkington 1977; Deacon and Deacon 1999). There is also evidence of a small, artisanal boat-based fishery along the west coast of South Africa from about the 1600 s (Sunde et al. 2011). During the 1800s following the abolition of slavery, many freed slaves and their families settled along the Cape coast. This together with the rising demand for fish from the colonial government led to the emergence of a number of fishing settlements along this coast (Van Sittert 1992).

The industrialisation of the South African fisheries, in particular the deep sea trawling and crayfish industries, can be traced back to the early 1900s under British rule. From 1902 until the start of the Second World, the development of the industry was largely financed by British capital (Croeser et al. 2006). It was not until the Great Depression of the 1930s that the South African government could challenge British control over the industry, reorganise the fisheries and implement access restrictions. By the mid-1930s, the authority to manage fisheries shifted from the provinces to the national government as the latter attempted to gain a measure of control over the rapidly expanding commercial fishing sector (Van Sittert et al. 2006). The promulgation of the Sea Shore Act in 1935 recognised the President as the 'owner of the sea shore and the sea', and ensured that the state retained control over management of 
marine resources. During this period, various legislative mechanisms were introduced, as well as the individual quota system, which further entrenched white monopoly over valuable marine resources. The state provided funding for infrastructure development, while the Fisheries Development Corporation, established in 1944, provided support for the post-war modernisation efforts, including funds for the upgrading of private fishing vessels (Van Sittert 2002). During this post war expansion period there was an increase in international interest in the fisheries sector while competition with foreign vessels, especially for hake resources, escalated. It was only with the proclamation of the Economic Exclusive Zone (EEZ) in 1977 that South Africa was able to restrict foreign vessels from fishing in its waters and this situation has been successfully maintained until the present.

As the industry developed along the Cape coast, local artisanal fishers were increasingly restricted from access to traditionally harvested resources and were instead employed in wage labour in the fishing industry - working on boats or in the factories along the west coast. By the 1960s, fisheries were a highly politicised sector and rights were granted based largely on political patronage (Van Sittert 2002).

A different scenario evolved along the east coast of South Africa, where harvesting of inshore resources by indigenous people was largely regulated by African customary law (Sunde et al. 2011), despite regulations restricting access and use. In these areas, there was limited interference by the colonial and later the apartheid governments in the allocation of access rights and management of resources. This was largely due to the remote and inaccessible nature of vast stretches of the east coast, and the relatively low value of coastal resources found along these coasts. Furthermore, during the Apartheid era, large stretches of the eastern seaboard were declared 'homelands'. ${ }^{13}$ In these traditional authority areas, rights to access marine resources were inextricably linked to relations of land tenure and social relations within the community (Sunde 2011). There is a dearth of literature on the customary systems that governed access to and use of marine resources but what is becoming clear from research in the land sector and more recent work on coastal resources (Sunde 2011) is that despite state regulations, customary systems were the de facto legal system operating during the 20 th century in many parts of the country (Sunde et al. 2011).

In general, the state did not interfere with customary systems governing the fisheries in the 'homeland' areas except in conservation areas where heavy fines were imposed for any transgressions. Where conflicts arose, they were addressed internally through sophisticated conflict resolution mechanisms that existed within these customary systems (Kapfudzaruwa and Sowman 2009; Sunde et al. 2011). In the case of the industrial sector, conflicts were handled through the legal systems set up in the Sea Fisheries Act. In the Benguela region, strict implementation of state rules effectively limited customary fishing activities and led to the erosion of local customary fishing systems, although there is evidence that fishers continued to fish outside the state system (Sunde, in prep). Conflict across the sectors in this region was minimised through imposition of draconian legislation, confiscations and heavy fines. Thus a de facto plural legal system based on vastly different philosophies, values and norms operated

\footnotetext{
${ }^{13}$ 'Homelands' is the term used to refer to the areas reserved for residence for African persons during Apartheid.
} 
in South Africa. Where conflict erupted between resources users from different governance regimes, state law prevailed and the norms and standards applied were skewed in favor of industry and state.

As the political struggle reached its peak in the 1980s and early 1990s, fishers increasingly engaged in 'illegal' fishing activities. In certain sectors, such as the abalone fishery, 'protest fishing' became common place as a means of challenging the lack of access to resources (Hauck 2009). As the struggle for political recognition by the majority swept the country, fishers became more vociferous in their demands and more brazen in terms of challenging fishery state law. Furthermore, the lack of legitimacy of the state system and failure of the state to recognise and respect local customary systems meant that conflicts (which were largely between fishers and the state) became increasingly asymmetrical during the 1980s and 1990s. The state continued to support big industry and push ahead with expansion of its conservation program and local fishers engaged in 'protest fishing'.

Following the democratic elections in 1994, South Africa embarked on an extensive law reform program. This process was guided by the new South African Constitution (1996), which was underpinned by a set of human rights principles contained in the Bill of Rights (Witbooi 2006). All organs of state were required to align their policies, laws and implementation actions to these fundamental rights, as well as other relevant Constitutional provisions. Thus by 1994, following industrialisation, decades of institutionalised racism and privatisation of the marine commons, the new ANC-led government was faced with a immense challenge of transforming an industry where ownership of marine resources was vested in a handful of white-owned companies. This process took place in a complex policy environment that included balancing the opportunities created by South Africa's reintegration into the global economy and the adoption of neo-liberal economic policies with the socially-orientated policies of the Reconstruction and Development Programme (RDP).

There were great expectations amongst poor coastal fishing communities that the new democratic government would deliver on its promise of "upliftment of impoverished coastal communities through improved access to marine resources" (ANC 1994: 104). However, despite participation of various sectors in deliberations regarding a new fisheries policy, representatives from historically disadvantaged communities were not well represented. Instead the deliberations were dominated by the large-scale fishing industry that had formed an alliance with organised labour and jointly pressed for the allocation of long term individual rights. This alliance was strongly opposed to state interference in the redistribution of resources to traditional fishers (Nielsen and Hara 2006). The three year law reform process culminated in the promulgation of the Marine Living Resources Act (1998), which sought to achieve three broad objectives: sustainability, equity and economic stability. Transformation of the industry was another key requirement of the Act, although no clear guidance was given on how this should be achieved (Section 2 ( $\mathrm{j}$ ) of the MLRA). A further provision that signalled the government's commitment to a new fisheries dispensation was the recognition of subsistence fishers as a legal category of fishers and the declaration of coastal areas for their exclusive use (Section 19).

Analyses of the fisheries reform process 10 years after the end of apartheid suggest that the achievements have been mixed at best (Van Sittert et al. 2006). There has certainly been transformation in the industry in the form of enhanced access to 
resources to historically disadvantaged individuals (HDIs), as well as the involvement of 'black' ${ }^{14}$ South Africans in the industry through share transfers, joint ventures and affirmative action appointments (van Sittert et al. 2006). Nielsen and Hara (2006), however, regard the transformation process as 'window dressing' in large part because the main fisheries remained in control of a small number of companies. With respect to the allocation of rights to the subsistence sector, aside from the province of Kwa-Zulu Natal along the north eastern coastal region of South Africa, very little progress has been made (Sowman 2006). This can partly be attributed to institutional inadequacies (Sowman 2006), but also to the narrow definition of subsistence in the MLRA, which failed to recognise the thousands of fishers that had historically engaged in artisanal fishing activities along the coast.

Failure to formally recognise the small-scale fishers and adequately cater for them resulted in mass action (Sunde 2003; Isaacs 2006); increased disregard of formal rules and regulations (Hauck and Kroese 2006; Hauck 2008; Sowman et al. 2011); and finally to legal action by a group of fishers against the DEAT Minister (George K and others vs. The Minister of Environmental Affairs and Tourism 2004). Mobilisation of the fishers was supported by Masifundise, a non-governmental organisation (NGO) that is focused on empowering coastal fishers to claim their rights to marine resources and support from the Legal Resources Centre. A key argument underlying this case was that government's failure to allocate rights to this group of fishers had violated their fundamental Constitutional rights, resulting in significant socio-economic hardship. A ruling by the Equality Court in May 2007 required the Minister responsible for fisheries to develop a policy that would address the needs of this hitherto excluded group and immediately provide 'interim relief' through access to marine resources until such time as the policy was finalised.

Following the Equality Court Ruling in 2007, a National Summit involving fishers from across South Africa was held to discuss concerns regarding the management of the sector. An outcome of this meeting was the appointment of a National Task Team (NTT) that included representatives from government and fisher communities, researchers, NGOs and Community-Based Organisation (CBOs) to develop a smallscale fisheries policy that would address the socio-economic rights of this group of fishers and ensure equitable access to resources. While the process of formulating the draft policy has been lengthy and difficult due to the very different perspectives of the many stakeholders involved, the principles, objectives and management approaches articulated therein indicate a fundamental paradigm shift in fisheries governance in South Africa. Thus the Equality Court ruling together with support from NGOs and a more informed and empowered fisher group provided the space for bottom-up participatory processes to take place.

The paradigm shift has multiple dimensions. Firstly, the final draft policy (DAFF 2010) recognises the rights and needs of small-scale fisheries and affords them legal protection. Secondly, it requires that these fishers be granted preferential access to marine resources, especially where such communities have historically depended on marine resources. Other key principles that signal a shift in approach include the

\footnotetext{
${ }^{14}$ 'Black' is a generic term used in South Africa for those ethnic groups identified by apartheid policy as 'Indian,' 'African' or 'Coloured.'
} 


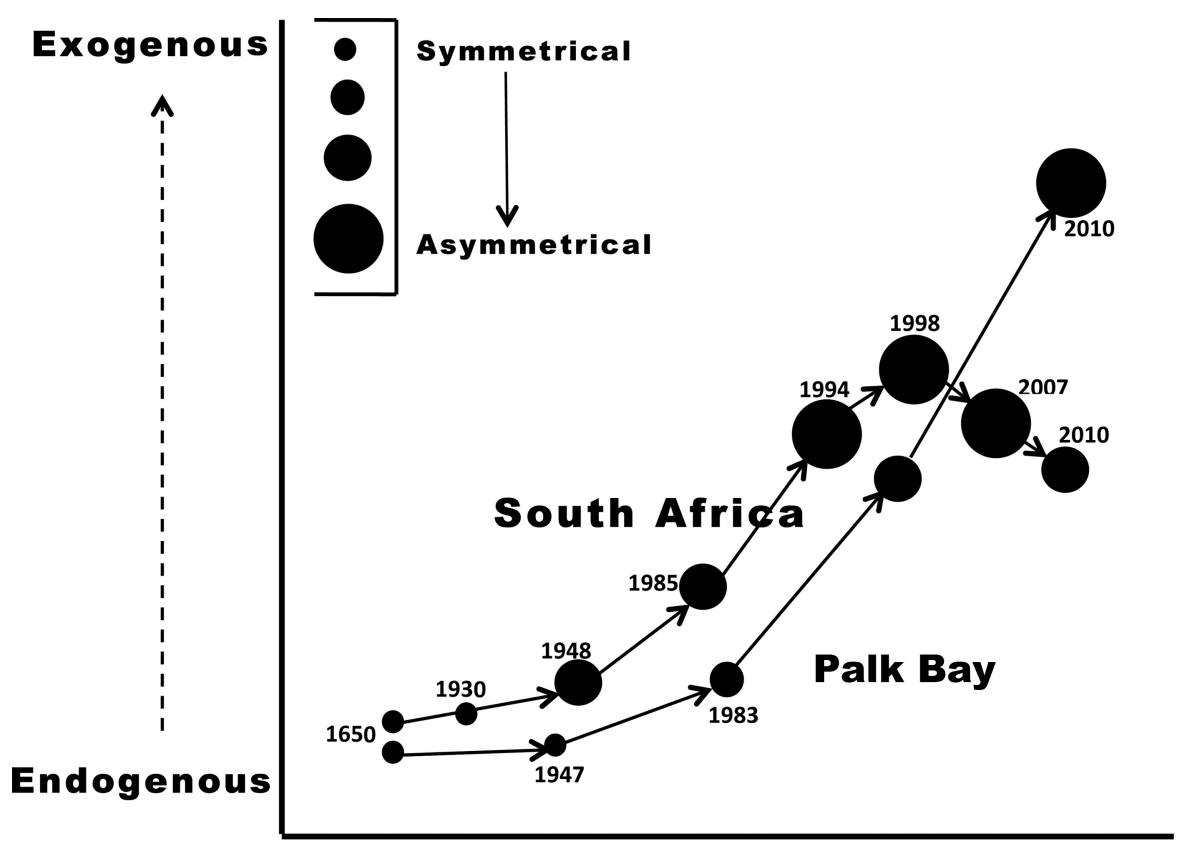

Monoistic

Pluralistic

Figure 9.I Trends of conflict and legal pluralism in South Asia and South Africa compared.

recognition of customary practices and law, promotion of a community-orientated approach, adoption of co-management, promotion of gender equity and the devolution of decision-making powers to local level institutions. The policy also requires dispute resolution mechanisms to be established locally. Although the policy has not yet been formally endorsed by Cabinet, Jaffer and Carstens (2011) have already heralded it as a victory for the fishers of South Africa.

\subsection{COMPARATIVE FRAMEWORK}

Figure 9.1 is an attempt to visualise key trends emerging in terms of fisheries conflicts in the two investigated regions. While there is evidence to suggest that the nature and intensity of conflict has followed similar trends since the advent of industrialisation, these two regions are on different trajectories. For definitions of key concepts we refer to Section 2 above.

In the case of Palk Bay, two trends emerge from the detail of fishing history since Independence: a fragmentation of legal regimes and governance arrangements through the entry of new governing agencies, and centralisation. The latter consists of the movement of influence over fishing from the shores to other loci of power. Both trends have 
bearing on the nature, intensity and duration of fishing conflict. The advent of legal pluralism in fishing has meant that conflicts, which were originally understood and addressed through a single legal prism, now have multiple interpretations. In terms of Rapoport (1974), they have shifted from being endogenous to exogenous conflicts. The relations between the conflicting fishing parties, but also between the governing actors involved, have also become asymmetrical. Trawler fishers enjoy more physical power than small-scale fishers do, and governments ultimately overrule fisher authorities. The fact that governments are further removed from the scene of conflict, and have a wider range of interests than fishing alone, affects the handling of the conflicts that occur. Whereas fishing conflicts in the Palk Bay scarcely had repercussions beyond its shorelines, they now reverberate at various societal scale levels. As a consequence, there are multiple contradictory interferences that impede effective resolution.

The conflicts that occur between Indian trawl fishers and small-scale fishers in Sri Lanka currently attract the most attention. Three types of governing interactions address these conflicts: interactions taking place (1) between government agencies, (2) between fishers, and (3) between fishers and government agencies. Building upon agreements on the International Boundary Line, concluded in 1974 and 1976, the governments of India and Sri Lanka installed a bilateral Joint Working Group (JWG) in 2005 for the purpose of finding an answer to the issue of border crossings (Suryanarayan 2009). Three JWG meetings have since occurred, but without any substantial results. Foreign policy and security interests play a complicating role. So too does the involvement of Tamil Nadu, which has other perspectives on the situation than does the central government.

Meanwhile, starting in 2004, NGOs initiated a dialogue between the fisher parties of India and Sri Lanka, with representatives travelling in both directions. An agreement between trawler fishers and small-scale fishers from the two countries was actually reached in August 2010 but not effectuated, due to a lack of governmental support. According to the agreement, trawl fishing in Sri Lankan waters would be phased out within a period of a year (Stephen et al. 2013).

Finally there have been repeated interactions between fisher organisations and governments in each of the two countries about the problems at hand. However, political equations and a strong distrust of NGOs seriously hamper this dialogue in Sri Lanka. As the small-scale fishers of the Palk Bay belong to the Tamil minority, which is only marginally represented in the Sri Lankan government, their voices are scarcely heard (Scholtens et al. 2012). The discussions that occur between trawler fisher organisations and government in India are distorted by public opinion that interprets the conflicts as taking place not between fisher parties, but between Indian fishers and the Sri Lankan navy. Recently, with the establishment of a Palk Bay Management Platform in India that includes representatives of fishers and government, a step forward seems to have been taken (pers. comm. V. Vivekanandan). Generally, however, pluralism and asymmetry between parties persist, and there is little evidence that fishing conflicts are close to an end.

In the case of South Africa, a number of trends are evident from the overview of fisheries development over the past century. The first is that post-1940, the state increasingly took control of the management of marine resources and supported privatisation of the marine commons. This, in turn, led to the erosion of customary systems where these two systems were juxtaposed. However, along parts of the east 
coast, fisheries resources continued to be governed under African customary law and conflicts were addressed internally. Thus a plural legal system emerged during the first half of the 20th century characterised by fragmentation of governance systems across the country and a move towards state centered decision-making. This trend has continued with South Africa's re-entry into the global arena, and the involvement of an increasing number of actors and institutions in the development and management of fisheries resources.

The shift to legal pluralism has also had implications for the nature and intensity of conflict, which in terms of the concepts guiding this analysis (Rapoport, 1974) indicate a shift from endogenous to exogenous conflict during the 20th century (Figure 9.1). Furthermore, because of the very different epistemological bases of the two legal systems operating at this time, as well as the norms and rules governing these systems, the relations between the conflicting parties - among fishers from different sectors and between fishers and the state - became increasingly asymmetrical. The lack of legitimacy of the state system among local resource users and the failure of the state to recognise customary systems meant that conflicts became increasingly asymmetrical during the 1980s and 1990s as the state continued to support big industry and push ahead with expansion of its conservation program and local fishers engaged in protest fishing. However, the enactment of the new Constitution (1996), the increased awareness among fishers of their rights and responsibilities, as well as the recent ruling of the Equality Court in 2007, has resulted in a shift to less exogenous and asymmetrical conflict. Different actors are now required to comply with the principles and provisions of the Constitution as stipulated by the courts.

Although the Constitution requires the recognition and respect of customary law, ${ }^{15}$ the application and interpretation of these provisions have only recently been tested in court. ${ }^{16}$ So while the fisheries sector in South Africa is still largely controlled at the center and the power differentials between the fishery actors remains unequal, the new fisheries policy (DAFF 2010) has embraced a set of human rights principles that recognises and protects the rights and socio-economic needs of small-scale fishers. Although the draft policy still requires Cabinet approval, it has been heralded as a victory and suggests a significant shift in approach to fisheries governance in South Africa (Jaffer and Cartsens 2011).

Despite the democratic elections in 1994, a radical law reform process, transformation of the industry and a restructuring within government and the fisheries agency in particular, poor coastal fishers remained marginalised and were not adequately recognised and provided for in the new fisheries dispensation following the end of apartheid. However, through increased access to information, mobilisation of fishers with support from NGOs and researchers, and legal action against the state, fishers have been able to significantly influence this policy process and its outcomes. Although it is too early to assess the impacts of this new policy, it embraces fundamental human

\footnotetext{
${ }^{15}$ Section 211 (3) of the Constitution of South Africa states that the courts are obliged to apply customary law when it is applicable, subject to the Constitution and any legislation that deals with customary law.

${ }^{16}$ Customary law has been recognized as a source of law in several cases by the Constitutional Court of South Africa for example S v Makwanyane and Another 1995 (3) SA 391 (CC) and Alexkor Ltd v The Richtersveld Community, 2004 (5) SA 460 (CC) (Wicomb and Smith, 2011).
} 
rights principles contained in the Constitution and promotes a style of governance that does justice to fisher interests, building from the bottom up.

\subsection{CONCLUDING REMARKS}

This chapter has investigated contemporary fisheries conflicts against the backdrop of the ideal-typical, historical shift from legal monism to pluralism; the latter, we argued, is the result of a substantial redefinition of the fisheries field due to industrialisation and globalisation. In the pre-industrial era, many of the world's coastal fisheries, including those of South Asia and South Africa, were marginal to the economy and to state affairs. Laws that regulated the allocation and use of resources emerged largely from within the fishing population itself, as the consequence of collective action and the development of customary law. Conflicts that took place could generally be dealt with within the framework of a commonly accepted legal system - in the terminology of Rapoport (1974), such conflicts were and are endogenous rather than exogenous in nature. Moreover, these conflicts were of a relatively symmetrical kind, as the conflicting parties occupied a more-or-less equivalent status and power position.

Industrialisation and globalisation fundamentally changed the nature of the fishing game, increasing production and linking formerly isolated regions to common markets. Although all fishers have in some way or other taken part in these processes, some actors have clearly benefitted more than others. The division between small- and largescale fisheries sub-sectors is a conspicuous feature of change in most parts of the world. The conflicts between these fisher categories are partly due to their negative interactions on the fishing grounds, but also to the power differentials that have come about. The fact that large-scale fishers no longer subscribe to existing fisher law but to other legal frameworks, is a substantial source of friction. Having changed in nature from endogenous to exogenous, fishing conflicts are now more explosive, of longer duration, and more difficult to resolve than they were before.

This is one reason why governments have been drawn into the field of fisheries regulation - as fishers themselves proved unable to solve many of the new problems that had come about, state agencies have stepped in, drafting law specifically for this purpose. Behind the background of their involvement, however, lies another factor: the wish to participate in the riches that the fisheries sector has now come to represent. According to this line of reasoning, legal pluralism in fisheries is thus intimately connected to processes of industrialisation and globalisation, which have taken place at various historical intervals across the globe.

Our argument has been that legal pluralism has complicated the fisheries picture, as the various parties refer to different bodies of law. Fishing conflicts, which had previously been endogenous, have now become exogenous, with no consensus about norms, rules and dispute resolution processes. The Palk Bay case illustrates this state of affairs. The fact that state law in this region is fundamentally divided - with governments of India as well as Sri Lanka claiming jurisdiction over marine territory complicates the situation even further. In the case of South Africa, decades of institutionalised racism and oppression of the black majority have also played a major role in shaping the fisheries sector. 
In addition to the fragmentation of law, we have drawn attention to the shift from symmetrical to asymmetrical relations, and to the fact that the focus of law and power has moved away from the coast and the fisheries. Now it is politicians and bureaucrats in Chennai, New Delhi, Colombo and Pretoria who hold keys to the resolution of fishing conflicts in South Asia and South Africa. Their actions, however, are perhaps less informed by the realities of fishing; they also have other concerns that are weighed against the costs and benefits of addressing fishing conflicts.

Although state law has thus become more influential in the fishing field, we have emphasised the continued relevance of fisher law for the resolution of conflict. Not only is fisher law more fine-grained and tuned to grounded realities than state law is, it also generally enjoys more legitimacy. Legitimacy is one of the prime conditions for compliance and enforcement, which in turn are essential to dispute management. There are thus, in addition to ethical concerns, very practical reasons for including fishers and fisher law in whatever comprehensive governance framework comes about.

It is to be remembered, however, that fisher interests and law are no longer homogenous, but instead highly fragmented and asymmetrical. Less influential fisher parties, such as populations of small-scale fishers, frequently require external support in achieving a fair and sustainable outcome. This may come from NGOs, social activists, government agencies and researchers.

Participatory governance is a process, but also an ideal that is seldom easy to achieve. This is certainly true where fisheries are characterised by legal pluralism and asymmetric power relations. Nonetheless, as we have illustrated in this chapter that opportunities for participatory governance have emerged as a result of both ecological pressures on the resource base as well as the introduction of more inclusive governance approaches in both South Asia and South Africa. The REINCORPFISH project hopes to build on these opportunities to contribute to advances in the direction of co-management.

\section{REFERENCES}

African National Congress (ANC). 1994. The Reconstruction and Development Programme (RDP), a policy framework. Johannesburg: Umanyamo Publications.

Alexander, P. 1982. Sri Lankan fishermen - rural capitalism and peasant society. Australian University Monographs on South Asia No. 7. Canberra: ANU.

Amarasinghe, O. 2005. Modernisation and change in marine small-scale fisheries of Southern Sri Lanka. Colombo: Navamaga Printers.

Amarasinghe, O. and M. Bavinck. 2011. Building resilience: fisheries cooperatives in southern Sri Lanka. In Poverty mosaics: realities and prospects in small-scale fisheries, ed. S. Jentoft and A. Eidem, 383-406. Dordrecht: Springer.

Bavinck, M. 1984. Small fry. The economy of petty fishermen in northern Sri Lanka. Free University Press, Amsterdam

Bavinck, M. 2001. Marine resource management. Conflict and regulation in the fisheries of the Coromandel Coast. New Delhi: Sage

Bavinck, M. 2003. The spatially splintered state: myths and realities in the regulation of marine fisheries in Tamil Nadu, India. Development and Change 34, no. 4: 633-657.

Bavinck, M. 2005. Understanding fisheries conflicts in the South - a legal pluralist perspective. Society and Natural Resources 18, no. 9: 805-820. 
Bavinck, M. 2011a. The Megaengineering of Ocean Fisheries: A Century of Expansion and Rapidly Closing Frontiers. In Engineering earth: the impacts of megaengineering projects, ed. S.D. Brunn, 257-273. Dordrecht: Kluwer.

Bavinck, M. 2011b. Governance, Poverty and Social justice in the Coastal Fisheries of India. In Local Governance and Poverty in Developing Nations, ed. N.R.M. Pouw and I.S.A. Baud, 115-136. Routledge Studies in Development and Society, New York: Routledge.

Bavinck, M. 2011c. Wealth, poverty, and immigration - the role of institutions in the fisheries of Tamil Nadu, India. In Poverty mosaics: realities and prospects in small-scale fisheries, ed. S. Jentoft and A. Eide, 173/191, Dordrecht: Springer.

Bavinck, M. and D. Johnson. 2008. Handling the legacy of the blue revolution in India - social justice and small-scale fisheries in a negative growth scenario. American Fisheries Society Symposium 49: 585-599.

Bavinck, M. and G.R. Woodman. 2009. Can there by maps of law? In Spatialising law: an anthropological geography of law in society, ed. F. von Benda-Beckmann, K. von BendaBeckmann and A. Griffiths, 195-218. Farnham: Ashgate Publishers.

Bavinck, M., D. Johnson, O. Amarasinghe, J. Rubinoff, S. Southwold, and K.T. Thomson. 2013. From Indifference to Mutual Support - A Comparative Analysis of Legal Pluralism in the Governing of South Asian Fisheries. European Journal of Development Studies Vol. 25, 4, 621-640.

Bayly, S. 1989. Saints, goddesses and kings - Muslims and Christians in South Indian Society, 1700-1900. Cambridge: Cambridge University Press.

Benda-Beckmann, F. von. 1995. Property rights and common resources. Paper read at Conference on Agrarian Questions, 22-24 May, Wageningen, The Netherlands.

Bennett, E., A. E. Neiland, E. Anang, P. Bannerman, A. A. Rahman, S. Huq, S. Bhuiya, M. Day, M. Fulford-Gardiner and W. Clerveaux. 2001. Towards a better understanding of conflict management in tropical fisheries: evidence from Ghana, Bangladesh and the Caribbean. Marine Policy 25: 365-367.

Berkes, F., R. Mahon, P. McConney, R. Pollnac and R. Pomeroy. 2001. Managing Small-scale Fisheries: Alternative Directions and Methods. Ottawa: International Development Research Centre (IDRC).

Birnie, P, and A. Boyle. 2002. International Law and the Environment 2nd Edition. Oxford: Oxford University Press

Branch, G. M. and B. M. Clark. 2006. Fish stocks and their management: the changing face of fisheries in South Africa. Marine Policy 30: 3-17.

Bromley, D.W. 2006. Sufficient reason: volitional pragmatism and the meaning of economic institutions. Princeton, NJ: Princeton University Press.

Butcher, J. G. 2004. The closing of the frontier - a history of the marine fisheries of Southeast Asia c. 1850-2000. Leiden: KITLV Press.

Charles, A. T. 2007. Adaptive co-management for resilient resource systems: some ingredients and the implications of their absence. In Adaptive Co-Management, ed. D. Armitage, F. Berkes and N. Doubleday, 83-102. Vancouver: UBC Press.

Cicin-Sain, B. and R. W. Knecht. 1998. Integrated coastal management-concepts and practices. Washington DC: Island Press.

Cinner, J. E. and S. Aswani. 2007. Integrating customary management into marine conservation. Biological Conservation 140, no. 3-4: 201-216.

Colding, J. and C. Folke. 2000. The taboo system: Lessons about informal institutions for nature management. The Georgetown International Environmental Review XII: 413-445.

Croeser, D., L. van Sittert and S. Ponte. 2006. The integration of South African fisheries into the global economy: Past, present and future. Marine Policy 30: 18-29.

Dalton, G. 1967. Traditional production in primitive African economies. In Tribal and peasant economies, readings in economic anthropology, ed. G. Dalton, 61-80. Austin, Texas: University of Texas Press. 
Deacon and Deacon 1999. Department of Agriculture, Forestry and Fisheries (DAFF). 2010. Draft Policy for the Small-scale Fisheries Sector in South Africa. Pretoria: DAFF.

Deacon, H. and J. Deacon. 1999. Human Beginnings in South Africa: Uncovering the Secrets of the Stone Age. Walnut Creek, CA: Altamira Press.

Defeo, O. and J. C. Castilla. 2005. More than one bag for the world fishery crisis and keys for co-management successes in selected artisanal Latin American shellfisheries. Reviews in Fish Biology and Fisheries 15: 265-283.

Delgado, C. L., N. Wada, M. W. Rosegrant, S. Meijer and M. Ahmed. 2003. Fish to 2020 supply and demand in changing global markets. In association with WorldFish Centre. Washington DC: International Food Policy Research Institute.

Eide, A., M. Bavinck, and J. Raakjaer. 2011. Avoiding poverty: distributing wealth in fisheries, In Poverty mosaics: realities and prospects in small-scale fisheries, ed. S. Jentoft and A. Eide, 13-26. Dordrecht: Springer.

Firth, R. 1946. Malay Fishermen: Their Peasant Economy London: Kegan Paul, Trench, Trubner

Food and Agriculture Organization. 2003. The Ecosystems approach to fisheries. FAO Technical Guidelines for Responsible Fisheries, No. 4, Suppl. 2. Rome: FAO.

Food and Agriculture Organization. 2011. The state of world fisheries and aquaculture. Rome: FAO.

Gerth, H. H. and C. W. Mills. 1948. From Max Weber: Essays in Sociology. London: Routledge \& Kegan Paul.

Hauck, M. 2008. Rethinking small-scale fisheries compliance. Marine Policy 32: 635-642.

Hauck, M. 2009. Rethinking small-scale fisheries compliance: from criminal justice to social justice. PhD diss., University of Cape Town, South Africa.

Hauck, M. 2011. Small-scale fisheries compliance: integrating social justice, legitimacy and deterrence. In Small-scale fisheries management: frameworks and approaches for the developing world, ed. R. S. Pomeroy and N. Andrew, 196-215. Oxfordshire, UK: CABI.

Hauck, M. and M. Sowman. 2003. Waves of change: coastal and fisheries co-management in South Africa. Cape Town: University of Cape Town Press.

Hauck, M. and M. Kroese. 2006. Fisheries compliance in South Africa: a decade of challenges and reform 1994-2004. Marine Policy 30: 74-83.

Hornell, J. 1950. Seeking pearls and chank shells in Ceylon and Indian waters. In Fishing in many waters, ed. J. Hornell, 182-189. London: The Syndics of the Cambridge University Press.

Hulme, D. and M. W. Muphree. 2001. African Wildlife and Livelihoods: The Promise and Performance of Community Conservation. Oxford: James Currey.

Isaacs, M. 2003. Understanding the social processes and the politics of implementing a new fisheries policy, the Marine Living Resource Act 18 of 1998, in South Africa. PhD diss., Cape Town: University of Western Cape.

Isaacs, M. 2006. Small-scale fisheries reforms: expectations, hopes and dreams for "a better life for all." Marine Policy 30: 51-59.

Jaffer, N. and C. Pederson. 2011. A Giant Leap. SAMUDRA no. 60.

Jaffer, N. and C. Pedersen. 2011. A giant leap. SAMUDRA Report 60: 27-30.

Jentoft, S. and B. McCay. 1995. User participation in fisheries management: lessons drawn from international experiences. Marine Policy 19: 227-246.

Jentoft, S. and B. McCay. 2003. The place of civil society in fisheries management: A research agenda for fisheries comanagement. In The fisheries co- management experience: accomplishments, challenges and prospects, ed. D. C. Wilson, J.R. Nielsen and P. Degnbol, 293-307. Amsterdam: Kluwer Academic Publishers.

Jentoft, S. 2007. The limits of governability: institutional implications for fisheries and costal governance. Marine Policy 31: 360-370.

Jentoft, S., M. Bavinck, D. S. Johnson and K. T. Thomson. 2009. Fisheries co-management and legal pluralism: how an analytical problem becomes an institutional one. Human Organization 68, 1: 27-38. 
Johnson, D. 2006. Category, narrative, and value in the governance of small-scale fisheries, Marine Policy 30: 747-756.

Johnson, D., M. Bavinck and J. Veitayaki. 2005. Fish capture. In Fish for Life: Interactive Governance for Fisheries, ed. J. Kooiman, M. Bavinck, S. Jentoft and R. Pullin, 71-92. Amsterdam: Amsterdam University Press.

Kapfudzaruwa, F and M. Sowman. 2009. Is there a role for traditional governance systems in South Africa's new water management regime? SA Water 35, no. 5: 683-692.

Kooiman J. 2003. Governing as Governance. Sage Publications: London

Kooiman, J. and M. Bavinck. 2005. The governance perspective. In Fish for Life: Interactive Governance for Fisheries, ed. J. Kooiman, M. Bavinck, S. Jentoft and R. Pullin, 11-24. Amsterdam: Amsterdam University Press.

Kooiman, J., M. Bavinck, S. Jentoft, and R. Pullin (eds.). 2005. Fish for Life: Interactive Governance for Fisheries. Amsterdam: Amsterdam University Press.

Kurien, J. 1988. Studies on the role of fishermen's organizations in fisheries management. The role of fishermen's organizations in fisheries management of developing countries (with particular reference to the Indo-Pacific region). FAO Fish. Technical Paper 300: 29-48.

Malinowski, B. 1992 (1922). Argonauts of the western Pacific: An account of native enterprise and adventure in the archipelagos of Melanesian New Guinea. London: Routledge and Keegan Paul.

McClanahan, T. R. and J. C. Castilla (eds.). 2007. Fisheries Management: Progress towards sustainability. Oxford: Blackwell Publishing.

McClanahan, T., Castilla, J., White, A. and O. Defeo. 2009. Healing small-scale fisheries by facilitating complex socio-ecological systems. Reviews in Fish Biology and Fisheries 19, no. 1: 33-47.

McConney, P., R. Pomeroy and R. Mahon. R. 2003. Guidelines for coastal resource comanagement in the Caribbean: communicating the concepts and conditions that favor success. Barbados: Caribbean Conservation Association.

McEvoy, A. F. 1986. The fisherman's problem - ecology and law in the California fisheries 1850-1980. Cambridge: Cambridge University Press.

McGoodwin, J.R. 1987. Mexico's Conflictual Inshore Pacific Fisheries: Problem Analysis and Policy Recommendations. Human Organization 46, no. 3: 221-232.

Nielson, J. R. and M. Hara. 2006. Transformation of South African industrial fisheries. Marine Policy 30: 43-50.

Ostrom, E. 1990. Governing the commons: The evolution of institutions for collective action. Campbridge: Cambridge University Press

Ostrom, E. 2007. A diagnostic approach for going beyond panaceas. Proceedings of the National Academy of Sciences 104, no. 39: 15181-15187.

Parkington, J. 1977. Soaqua: hunter-fisher-gatherers of the Olifants River valley Western Cape. The South African Archaeological Bulletin 32, no. 126: 150-157.

Pinkerton, E. 2009. Partnerships in Management. In Fishery managers' guidebook: management measures and their application 2nd Edition, ed. K. Cochrane K and S. Garcia, 158-173. Oxford: John Wiley \& Sons.

Platteau, J.P. 1989. The dynamics of fisheries development in developing countries: a general overview. Development and Change 20, no. 4: 565-599.

Pomeroy, R. 1995. Community-based and co-management institutions for sustainable coastal fisheries management in Southeast Asia. Ocean and Coastal Management 27: 143-162.

Pomeroy, R. and M. Carlos. 1997. Community-based coastal resource management in the Philippines: a review and evaluation of programmes and projects 1984-1994. Marine Policy 21: 445-464.

Pospisil, L. 1971. Anthropology of Law. A Comparative Theory. Harper and Row: New York.

Radcliffe-Brown, A. R. 1922. The Andaman islanders - a study in social anthropology. Cambridge: University Press. 
Rapoport, A. 1974. Conflict in man-made environment. Harmondsworth, Middlesex: Penguin. Rheinstein, M. 1954. Introduction. In Max Weber on Law in Economy and Society, ed. M. Weber, xxv-lxxi. Cambridge: Harvard University Press.

Ribot, J. C. 2004. Waiting for Democracy: The Politics of Choice in Natural Resource Decentralization. Washington, DC: World Resource Institute Report.

Roche, P.A. 1984. Fishermen of the Coromandel - the social study of the Paravas of the Coromandel. New Delhi: Manohar Publications.

Ruddle, K. and A. Satria (eds.). 2010. Managing Coastal and Inland Waters: Pre-existing Aquatic Management Systems in Southeast Asia. Dordrecht: Springer Publishing Company.

Sathyapalan, J., J. Srinivasan and J. Scholtens. 2007. Fishing Fleet Reduction and its livelihood implications: a case study of Palk Bay resource users in the east coast of Tamil Nadu, India. Amsterdam: Amsterdam Centre for Maritime Research.

Scholtens, J., M. Bavinck and A. S. Soosai. 2012. Fishing in dire straits - a Sri Lankan perspective on trans-boundary incursions of Indian trawlers in the Palk Bay. Economic and Political Weekly 47, no. 25: 87-95.

Scott, J. C. 2009. The art of not being governed - an anarchist history of upland Southeast Asia. Yale: Yale University Press.

Smith, H. D. 1994. The development and management of the world ocean. Ocean \& Coastal Management 24: 3-16.

Smith, H. D. 2000. The industrialization of the world ocean. Ocean \& Coastal Management 43, millennium essay: 11-28.

Sowman, M. 2006. Subsistence and small-scale fisheries in South Africa: a ten year review. Marine Policy 30: 60-73.

Sowman, M., P. Fielding, M. Hauck, S. Williams, K. Neethling and T. Phillips. 2008. Effective sustainable livelihood options for fishers in three coastal communities. Report prepared by the Environmental Evaluation Unit, University of Cape Town, for the National Environmental Advisory Forum of the Department of Environmental Affairs and Tourism, Pretoria, May 2008.

Sowman, M., M. Hauck, L. van Sittert and J. Sunde. 2011. Marine Protected Area Management in South Africa: New Policies, Old Paradigms. Environmental Management 47, no. 4: 573-583.

Stephens, J., A. Menon and M. Bavinck. 2013. Brothers at sea: Transboundary fisher dialogue and the 'politics of scale' in Palk Bay fisheries 33 (2): 141-161.

Stirrat, R. L. 1988. On the beach: fishermen, fishwives and fishtraders in post-colonial Lanka. Oxfordshire, UK: CABI.

Sunde, J., 2011. Dwesa-Cwebe scoping report. Unpublished report. Cape Town: Environmental Evaluation Unit, University of Cape Town.

Sunde, J. 2003. Access and rights to the "marine commons" in South Africa: Perspectives, lessons and possibilities for future action. South Africa: Masifundise Development Trust.

Sunde, J., M. Sowman, H. Smith and W. Wicomb. 2011. Emerging proposals for governance of tenure in small-scale fisheries in South Africa. Paper prepared for the Governance of Tenure for Responsible Capture Fisheries A UN/FAO Fisheries and Aquaculture Department Initiative.

Sunde, J., Sowman, M., Smith, H. and W. Wicomb. 2013. Emerging proposals for governance of tenure in small-scale fisheries in South Africa. FAO Land Tenure Journal. FAO, Rome, Italy.

Suryanarayan, V. 2005. Conflict over fisheries in the Palk Bay region. New Delhi: Lancer Publishers.

Suryanarayan, V. and R. Swaminathan. 2009. Contested Territory or Common Heritage? Thinking out of the box. Madras: Ganesh and Co. Publishers.

Thorpe, A. and E. Bennett. 2001. Globalisation and the sustainability of world fisheries: a view from Latin America. Marine Resource Economics 16: 143-164. 
Vanderlinden, J. 1972. Le pluralisme juridique, essai de synthese. In Le pluralisme juridique, ed. J. Gilissen, 19-36. Brussels: l'Université de Bruxelles.

Van Ginkel, R. J. 1987. Pigs, Priests and other Puzzles: Fishermen's Taboos in Anthropological Perspective. Ethnologia Europaea 17, no. 1: 57-68.

Van Sittert, L. 2002. "Those who cannot remember the past are condemned to repeat it": comparing fisheries reforms in South Africa. Marine Policy 26: 295-305.

Van Sittert, L., G. Branch, M. Hauck and M. Sowman. 2006. Benchmarking the first decade of post-apartheid fisheries reform in South Africa. Marine Policy 30: 96-110.

Venkataraman, K. and M. Wafar. 2004. Coastal and marine biodiversity of India. Indian Journal of Marine Sciences 43, no. 1: 57-75.

Von Brandt, A. 1984. Fish catching methods of the world 3rd edition. Farnham: Fishing News Books Ltd.

Weber, M. 1954. Max Weber on Law in Economy and Society. Cambridge: Harvard University Press.

Wicomb, W. and H. Smith. 2011. Customary communities as 'peoples' and their customary tenure as 'culture': what we can do with the Endorois decision. African Human Rights Law Journal 11, no. 2: 422-446.

Witbooi, E. 2006. Law and fisheries reform: Legislative and policy developments in South African fisheries over the decade 1994-2004. Marine Policy 30: 30-42.

World Bank. 2008. The sunken billions - the economic justification for fisheries reform. Washington DC: Agriculture and Rural Development Department, World Bank and FAO. 



\title{
An Analytical Framework For Assessing the Impacts of Jatropha Curcas on Local Livelihoods
}

\author{
Joleen A. Timko'
}

\begin{abstract}
In spite of claims promoting the attributes of Jatropha curcas, there are many misconceptions, unsubstantiated claims and research gaps that need to be considered, particularly given the projected expansion of Jatropha cultivation across the tropics. It is thus an opportune time to assess the impacts of Jatropha from the perspective of rural livelihoods. The analytical framework presented in this chapter is intended to assist those at the local level in assessing the potential impacts of Jatropha (or other biofuel) projects. Three key lessons emerged from recent case study investigations into the socio-economic impacts of Jatropha in Ghana and Ethiopia - local consultation about potential biofuel projects is imperative, land alienation and decreases in the size of household landholdings must be minimised or mitigated, and Jatropha must have positive household-level socio-economic impacts. These form the basis of the analytical framework as the key criteria that local people could use to assess the potential impacts of Jatropha cultivation, production, and usage on their livelihoods. A detailed review of the relevant published and grey literature focused specifically on Jatropha, but drawing on more general biofuel-related literature as necessary, has identified the potential indicators in the framework. Wherever possible, conflicts and potential avenues for cooperation around Jatropha have been identified. This framework should be of use in other locations to assess Jatropha-related impacts, and could be amended to assess the livelihood impacts of other types of biofuels as well.
\end{abstract}

Keywords Jatropha, socio-economic impact, livelihoods, Africa, Ghana, Ethiopia.

\section{IO.I INTRODUCTION}

In recent years, biofuels from plant oils have rapidly emerged as a major issue for agricultural development, energy policy and natural resource management. The enthusiasm of African governments for biofuel development over the past few years has accompanied the hope that these fuels would provide new market opportunities and economic benefits (Amsalu and Kinfu 2013). Biofuels are thus presented as a sustainable source of higher income for farmers in Africa and are promoted as a means to

\footnotetext{
${ }^{1}$ Research Associate, University of British Columbia, Vancouver, Canada (Corresponding author: joleen.timko@ubc.ca).
} 
improve rural livelihoods, reduce poverty and stimulate rural development. In spite of the potential of biofuel plantations to reinvigorate Africa's rural areas through job creation and income generation, apprehension about the negative environmental and social impacts of large-scale commercial biofuel production remains (Acheampong 2013). Indigenous farming systems, local communities and the biodiversity they manage are pushed aside in favour of the increased fuel needs of the industrialised world (Gebremedhine 2008). At the same time, there are concerns that large-scale biofuel development could cause rising food prices, land grabbing, ecological damage, wildlife destruction and disruption of rural livelihoods (Amsalu and Kinfu 2013). Many countries do not have the legal or procedural mechanisms in place to protect local rights, or to take into account local interests, livelihoods and welfare. Even where legal requirements for community consultation are in place, the involvement of local communities in the negotiation process is not guaranteed. Insecure use rights on state-owned land, inaccessible registration procedures, vaguely defined productive use requirements, legislative gaps, and compensation limited to loss of improvements like crops and trees (thus excluding loss of land) all undermine the position of local people (Cotula et al. 2009).

Africa has become an important target producer of the necessary feedstocks for biofuel production. In particular, land has been acquired for production of Jatropha curcas as a feedstock for biofuel production in Ghana and Ethiopia. Jatropha curcas, commonly called the physic nut, now grows pantropic even though its native range is tropical America (Achten et al. 2007). Jatropha is a plant with many attributes and considerable potential (Openshaw 2000). It has been promoted for its numerous woody by-products, such as pruning waste and fruit hulls that can be combusted locally as a fuel source (Achten et al. 2010), and those by-products of use in micro-industries, such as the manufacturing of soaps and candles. Jatropha is thought to help prevent soil erosion caused by rainwater, reclaim degraded lands, and act as a living fence to exclude browsing animals (Openshaw 2000; Achten et al. 2007; Achten et al. 2008; Achten et al. 2010). It is also of great interest to the global biofuel industry as a feedstock. Trends around the world indicate a shift towards Jatropha as a viable and sustainable alternative to traditional biodiesel feedstocks, such as palm and soya (KnowGenix 2007). In 2008, Jatropha was planted on an estimated 900,000 ha globally, of which 760,000 ha (85 percent) were in Asia, followed by 120,000 ha in Africa (mostly in Madagascar and Zambia, but also in Tanzania and Mozambique), and 20,000 ha in Latin America (Brittaine et al. 2010). It is postulated that over half of the land in Africa is suitable for Jatropha cultivation (Jingura et al. 2011).

In spite of claims promoting Jatropha's attributes, there are many misconceptions, unsubstantiated claims and research gaps that need to be considered, particularly given the projected expansion of Jatropha cultivation across the tropics. After all, Jatropha is still a wild plant; many of its basic properties are not thoroughly understood and the environmental effects have yet to be investigated (Achten et al. 2008). A number of dubious claims surrounding Jatropha suggest that it will enhance socio-economic development while reclaiming marginal and degraded lands; is drought tolerant; is a high yielding crop; grows well under saline conditions; and does not compete with food production. Yet there is very little, if any, evidence to substantiate these types of claims. There is a lack of information about Jatropha's potential yield under sub-optimal and marginal conditions (Jongschaap et al. 2007; Ariza-Montobbio et al. 2010a; Brittaine 
et al. 2010), as well as the long-term impacts of large scale Jatropha projects on soil quality and the environment (Weyerhauser et al. 2007).

Given the recent expansion of industrial Jatropha projects amidst a lack of information about the socio-economic impacts of such projects and plants, it is an opportune time to assess the impacts of industrial Jatropha plantations from the perspective of local livelihoods. The analytical framework presented in this chapter is intended to assist those at the local level in assessing the potential impacts of Jatropha (or other biofuel) projects. This chapter is divided into three sections. Following this introduction, the second section of this chapter presents the analytical framework and its origins. Each of the three criteria form a sub-section in order to explore the indicators and sub-indicators associated with it. The third and final section offers brief concluding remarks by emphasizing the numerous opportunities for cooperation on Jatropha-related projects.

\section{I0.2 THE ANALYTICAL FRAMEWORK}

Recent case study investigations of the socio-economic impacts of Jatropha in Ghana and Ethiopia have revealed that local respondents were not consulted about the establishment of Jatropha plantations. Partly because of this, they suffered a decrease in household landholdings and subsequent livelihood impacts on household socioeconomic status, food security, fallow periods, and fodder availability (Timko et al. 2013). The three key lessons - the importance of local consultation, the risks associated with land alienation and decreases in the size of household landholdings, and household-level socio-economic impacts - form the basis of the analytical framework as the key criteria that local people could use to assess the potential impacts of Jatropha cultivation, production and usage on their livelihoods. Wherever possible, this paper distinguishes between the livelihood impacts that arise from Jatropha at the industrial plantation scale and the community/local scale (including smallholder farmers growing Jatropha for local use, as living fences or in agroforestry systems with Jatropha intercropping). The criteria, indicators and potential sub-indicators are listed in Table 10.1. These are listed in such a way as to indicate the optimum outcome - 'more of each' is the preferred condition in terms of contributing positively to local livelihoods. Wherever possible, recommendations for reducing conflicts and increasing cooperation are given.

The framework in this chapter was developed in two stages. First, an extensive list of potential socio-economic impacts of industrial biofuel projects was deductively identified through a comprehensive review of the relevant published and grey literature focused specifically on Jatropha. Where necessary, the research drew on more general biofuel-related literature. While Jongschaap et al. (2007) outline several potential indicators on this front, the criteria and indicators presented in this chapter are believed to be the most elaborated list of socio-economic impacts of Jatropha at the time of writing. The literature review was completed in January 2011 through a search of CAB Direct, Social Sciences in Forestry and ISI Web of Knowledge, using search terms such as Jatropha, Jatropha social, Jatropha impact, etc. Papers that had as their main focus Jatropha-related production, such as transerification, or biochemical and nutritional evaluations, were eliminated from this review as they were not focused on the social and environmental aspects of Jatropha cultivation, production and usage. 
Table 10.I An analytical framework consisting of criteria, indicators and potential sub-indicators for assessing the impacts of Jatropha cultivation, production, and usage on local livelihoods.

\begin{tabular}{ll}
\hline Criterion & Indicator \\
\hline Local people & Jatropha-related \\
consulted about & knowledge and \\
potential biofuel & information needs \\
projects proposed & of local farmers \\
for their regions & addressed
\end{tabular}

Sub-Indicators

- Local farmers supplied with reliable and unbiased information about Jatropha

- Local farmers informed of where to get further information about Jatropha

- Documents pertaining to proposed Jatropha-related projects translated into local language

- Documents pertaining to proposed Jatropha-related projects presented orally

Processes for conflict resolution (consultation and participation) to reduce conflict, coercion, and corruption enhanced

Local landholdings are maintained/ decreases in size are minimised and mitigated

Traditional access to land and water by local people is maintained

By-products from Jatropha are used locally to support development

Local food security enhanced/Impacts on arable land minimised
- Opportunities exist for local people to be involved in Jatropha projects

- Local perceptions re: trust and cooperation with government/companies are positive

- Well-publicised public consultations about proposed Jatropha projects held in easily accessible locations

- Ample notification about public meetings supplied locally

- Jatropha plantations not sited on contested land

- Full, prior and informed consent (FPIC) sought from relevant stakeholders

- Local perceptions re: trust and cooperation with community leaders is positive

- Community leaders consult constituents regarding proposed Jatropha projects

- Documents pertaining to proposed Jatropha-related projects translated into local language

- Documents pertaining to proposed Jatropha-related projects presented orally

- Companies fulfill commitments to buy back Jatropha produce at remunerative prices

- Government policies support tenure over land for local people

- Compensation for changes in household landholdings is deemed appropriate

- Decentralised and alternative land-holding structures (village trusts, joint ventures, cooperatives) exist

- Outsourcing Jatropha cultivation to local farmers encouraged and practiced

- No displacement of local people from land they previously used

- All proposed land use changes require local consent

- Access routes to traditional watering points or fodder grounds remain open

- No influx of new farmers from other areas under Jatropha cultivation

- Local people use Jatropha for medicinal purposes

- Local people use seedcake/presscake for manure

- Local people use Jatropha as a living fence

- Local people use Jatropha oil for soap/heating/ cooking/lighting/diesel

- Jatropha grown on uncontested land

- Jatropha grown on land not used for food production

- Income from Jatropha used to purchase food locally

- Intercropping Jatropha with food crops practised

- Jatropha does not decrease fodder availability 
Table 10.I (continued)

\begin{tabular}{|c|c|c|}
\hline Criterion & Indicator & Sub-Indicators \\
\hline & $\begin{array}{l}\text { Health risks } \\
\text { associated with } \\
\text { cultivation and } \\
\text { production of } \\
\text { Jatropha are } \\
\text { minimised }\end{array}$ & $\begin{array}{l}\text { - Measures taken to protect human skin in Jatropha } \\
\text { cultivation }\end{array}$ \\
\hline & $\begin{array}{l}\text { Local women } \\
\text { capitalise on the } \\
\text { benefits of Jatropha } \\
\text { systems }\end{array}$ & $\begin{array}{l}\text { - Jatropha-oil stoves used by women locally } \\
\text { - Time spent collecting firewood decreased } \\
\text { - Small-scale Jatropha-related spin-off industries cre- } \\
\text { ated by local women } \\
\text { - Women retain role as knowledge providers regarding } \\
\text { subsistence crops }\end{array}$ \\
\hline & $\begin{array}{l}\text { Local people benefit } \\
\text { economically from } \\
\text { Jatropha }\end{array}$ & $\begin{array}{l}\text { - Jatropha oil available locally } \\
\text { - Jatropha oil locally affordable } \\
\text { - Affordable opportunities for local farmers to engage } \\
\text { in Jatropha projects } \\
\text { - Long-term credit available to local Jatropha farmers } \\
\text { - Labour requirements of Jatropha cultivation manage- } \\
\text { able (affordable, available as required) }\end{array}$ \\
\hline & $\begin{array}{l}\text { Institutions } \\
\text { developed to enable } \\
\text { financing of local } \\
\text { Jatropha initiatives }\end{array}$ & $\begin{array}{l}\text { - Co-operatives enable local involvement in Jatropha } \\
\text { projects } \\
\text { - Mico-credit available to enable local involvement in } \\
\text { - Jatropha projects } \\
\text { Joint ventures enable local involvement in Jatropha } \\
\text { projects }\end{array}$ \\
\hline & \multirow[t]{3}{*}{$\begin{array}{l}\text { Technology } \\
\text { requirements for } \\
\text { Jatropha cultivation } \\
\text { and production } \\
\text { addressed }\end{array}$} & $\begin{array}{l}\text { Cultivation } \\
\text { - Fertilisers available for Jatropha cultivators } \\
\text { - Irrigation available for Jatropha cultivators } \\
\text { - Pesticides/Insecticides available for Jatropha } \\
\text { cultivators }\end{array}$ \\
\hline & & $\begin{array}{l}\text { Processing } \\
\text { - Seed presses manufactured locally } \\
\text { - Seed presses repaired locally }\end{array}$ \\
\hline & & $\begin{array}{l}\text { Usage } \\
\text { - Modified engines/lamps/stoves available } \\
\text { - Modified engines/lamps/stoves affordable } \\
\text { - Modified engines/lamps/stoves repaired locally } \\
\text { - Jatropha oil available locally } \\
\text { - Jatropha oil locally affordable }\end{array}$ \\
\hline & $\begin{array}{l}\text { Impacts on water } \\
\text { resources } \\
\text { minimised }\end{array}$ & $\begin{array}{l}\text { - Water balance in Jatropha-growing regions increased } \\
\text { - Soil erosion in Jatropha-growing regions decreased } \\
\text { - Conflicts over access to water in Jatropha-growing } \\
\text { regions decreased } \\
\text { - Water pollution in Jatropha-growing regions } \\
\text { decreased }\end{array}$ \\
\hline & $\begin{array}{l}\text { Impacts on marginal } \\
\text { and forest lands } \\
\text { minimised }\end{array}$ & $\begin{array}{l}\text { - Local perceptions about 'marginal/wasteland' match } \\
\text { those of government and industry } \\
\text { - Forest cover retained } \\
\text { - No loss of primary forest cover for Jatropha cultiva- } \\
\text { tion }\end{array}$ \\
\hline
\end{tabular}


Second, the framework was inductively refined through in-depth case study investigation into the actual socio-economic impacts of Jatropha projects in Ghana and Ethiopia. This study used primary data from a household questionnaire administered to 399 households (165 in Ethiopia, 234 in Ghana) in 2011. Further discussion of the methods employed can be found in Timko et al. (2013). Questionnaire respondents in Ghana were residents in communities affected by Jatropha cultivation. Approximately $60 \%$ of questionnaire respondents in Ethiopia were residents in communities affected by Jatropha ( $40 \%$ were affected by Castor bean (Ricinus communis). Despite these being different biofuel feedstocks, the experiences of local respondents did not differ by feedstock type, and were common to those affected by Jatropha in Ghana. Hence, criteria and indicators (C\&I) common to both feedstocks are presented as relevant to Jatropha in this chapter. Given the breadth of literature used in formulating the C\&I, this framework may be amenable to assessing the impacts of other types of biofuels in other localities.

It is also acknowledged that although the C\&I discussed in this chapter are a good step towards assessing the socio-economic impacts of Jatropha on rural livelihoods, there are challenges associated with reducing livelihoods in developing countries to just a few variables. The indicators are quite different in scope, ranging from precise measures amenable to quantitative assessment to very broad and diffuse indicators requiring qualitative assessment. Moreover, the notion of 'sustainable livelihoods' is a moving target always subject to negotiation as it is a composite of many ideas and interests, as variable as the regions in which it is being sought (sensu Scoones 1998). Nevertheless, because different people will inevitably have different views as to the priority of indicators, the strength of using a criteria and indicators approach is that the conflicts between these priorities can be highlighted, and trade offs and choices made between them can be made more explicit (Scoones 1998). Hence, opportunities for cooperation can too be made explicit. The remainder of this section explores in detail the potential indicators associated with each of three main criteria in the framework.

\subsection{Local people are consulted about potential biofuel projects}

Case study research in Ghana and Ethiopia demonstrated that local people wanted to be, but had not been, consulted about potential Jatropha projects in their regions (Timko et al., 2013). This section presents two indicators for assessing how proposed Jatropha projects are addressing the issue of local consultation: 1) the Jatropha-related knowledge and information needs of local farmers are addressed; and 2) processes are in place to reduce coercion and corruption, and enhance local participation.

\section{Jatropha-related knowledge and information needs of local farmers addressed}

In order for farmers to be able to make a decision that balances the risks and benefits of Jatropha cultivation, it is imperative that they have access to reliable and accurate information that is supported by evidence. Unfortunately, this rarely happens. In Tanzania, there is a systemic lack of information available to local villagers on specific aspects of the Jatropha cultivation regime (Van Eijck et al. 2008). In cases elsewhere, uneven 
relations of knowledge transfer result in the dependence of farmers on companies for technical expertise and advice in addition to growing material (Ariza-Montobbio et al. 2010a). This can be highly problematic. For instance, many buyers are well aware of the fact that the maximum period that Jatropha seeds can be stored is approximately three months before the level of acidity is too high, while communities may be unaware of this and may be improperly trained to store the seed properly (Ribeiro et al. 2009). In order for Jatropha to make positive contributions to local livelihoods, these gaps in information provisioning must be addressed.

\section{Processes to reduce conflict, coercion and corruption are enhanced}

A number of conflicts have emerged around large-scale Jatropha projects. Successful examples of Jatropha cultivation on a plantation scale are rare, mainly due to low profit margins, low yields and unrealistic expectations (Asselbergs et al. 2006). In Tamil Nadu, companies and NGOs promoting Jatropha were seen as deliberately deceiving rural farmers and as being responsible for a loss of local livelihoods when crops failed, returns on investment did not materialise, and companies refused to buy the produce at remunerative prices (Ariza-Montobbio et al. 2010a; 2010b). Of particular concern regarding large-scale Jatropha projects are the methods used to acquire land. A lack of public participation, disregard for local culture and practices, false promises, corruption, land conflicts, and resource grabs have characterised many land acquisitions in Mozambique (Ribeiro et al. 2009). Several larger-scale initiatives have displayed corruption on behalf of community leaders. In some instances, investors and government officials have bribed community leaders in order to gain community consent without community consultation (Ribeiro et al. 2009). The use of out-grower and other contracted smallholder arrangements have proven to be more equitable than large-scale plantations in terms of land access, and these could represent a positive model for local livelihoods and the environment (Sulle et al. 2009).

Efforts to consult and resolve Jatropha-related conflicts with local people have been found wanting. In Tanzania and Mozambique, processes have been characterised by weak dissemination of community rights and information, little translation of documents into local languages, a lack of transparency, and little to no opportunity for local farmers to be engaged in Jatropha farming (Ribeiro et al. 2009; Mutch 2010). There is a need for processes that enhance community participation in Jatropha-related discussions, particularly before any land has been ceded to these initiatives or decisions have been made about them. This is particularly important in light of the fact that many rural communities lack the resources for and information on legal processes (Ribeiro et al. 2009). Free prior and informed consent, based on secure land tenure of local residents, should be a fundamental requirement, and production on contested land should be prevented (Cotula et al. 2008).

\subsubsection{Impacts on local landholdings and land use are minimised}

Our case study investigation revealed that local respondents were not consulted about potential Jatropha projects in their regions, and were surprised to learn that their 
household landholdings had been reduced because of the arrival of industrial Jatropha plantations. Due to the serious consequences that can accompany reductions in landholding (such as less food security and decreased periods of time to fallow land), it is prudent that local landholdings are maintained, any decreases in size are minimised and mitigated and happen through open negotiation, and that traditional access to land by local people is maintained.

\section{Local landholdings are maintained, decreases in size are minimised and mitigated}

Government policies must support tenure over land for local people in order to prevent land from being acquired (legally or covertly) by Jatropha companies. Moreover, any changes in household landholdings must be determined through negotiation and must be met with compensation that is deemed appropriate by local people. Large-scale acquisitions of land are not necessarily required to support Jatropha cultivation, and consideration for any biofuel project should occur on a smaller-scale, as these may have the best chance of success (Asselbergs et al. 2006). For instance, Diligent Energy Systems in Tanzania owns no land, instead 'outsourcing' the growing in such a way that villagers receive the economic benefits such as money for seeds and cultivation, along with secondary benefits including oil for cooking stoves, lamps, oilseed cake, soap and fertiliser for use on other crops (Mutch 2010). Local people could benefit from this type of system, as well as from policies that promote land ownership and thereby give them increased security (Franken 2009). Projects such as small Jatropha plantations, agroforestry systems with Jatropha intercropping and agro-silvo-pastoral systems can also benefit adopting farmers by enabling them to individually limit their initial investment and control their start-up risk (Achten et al. 2010). Decentralised and alternative land holding structures, such as village land trusts or equity-based joint ventures, could be an effective means of stimulating private investment and allow for greater collaboration between investors and local communities (Sulle et al. 2009). Decentralised approaches can also benefit the cultivation of Jatropha as they rely on the development of agricultural knowledge by local farmers to determine the optimal growing conditions under a range of local conditions (Asselbergs et al. 2006). Cooperatives, one such decentralised approach, have been lauded as they "can provide the scale effects, security and infrastructure needed to balance large-scale producers and processes” (Asselbergs et al. 2006).

\section{Traditional access to land by local people is maintained}

The cultivation of biofuels can result in changes to land access for poor people through two routes: direct and indirect (Cotula et al. 2008). Direct changes occur when land use is transformed into biofuel crop production from other uses, such as farming (Cotula et al. 2008). The acquisition of large areas of land for biofuel production is a concern that threatens access to land, fodder and water by the poor in rural areas where land tenure systems are weak (Brittaine et al. 2010), pushing farmers off their land and deeper into poverty (Green 2009). In Tamil Nadu, for example, 50\% of respondents reported that their access to fodder was directly reduced by their shift to Jatropha (the other $50 \%$ either did not own cattle or were able to obtain fodder or grazing from other lands) (Ariza-Montobbio et al. 2010a; 2010b). In the Kisarawe district of 
Tanzania, a Jatropha project is reported to have involved the acquisition of 9,000 ha of land and the clearance of 11 villages home to 11,277 people (Cotula et al. 2008). At a minimum, any land use changes that are proposed for biofuel expansion should require local consent. All access routes to traditional watering points, fodder groups and the like must remain open for local use.

Indirect changes in land use, also known as 'displacement' or 'leakage,' are triggered by biofuel expansion elsewhere (Cotula et al. 2008). Although information on this type of land use change is lacking in the literature on Jatropha, it is feasible that Jatropha planted on higher-value lands could displace food crops into less fertile areas, increasing the risk of conflicts between the 'new' and 'existing' farmers.

\subsubsection{Household-level socio-economic impacts are addressed}

There are a multitude of ways that Jatropha, when grown locally and at smaller scales such as outgrower schemes, can benefit local people. The use of the term 'Jatropha system' in this chapter refers to the use of Jatropha in an integrated rural development approach whereby Jatropha is used for a variety services, including as a source of oil, living fence, soap production, lighting and cooking, and as fuel for engines (Henning 2004). In this way, a Jatropha system combines ecological, economic and incomegenerating effects, the latter of which is particularly beneficial to women (Henning 1998). This section considers a number of ways in which Jatropha can enhance livelihoods to benefit local people, and how health risks associated with Jatropha cultivation and production can be minimised.

\section{By-products from Jatropha are used locally to support development}

There are several ways in which Jatropha's by-products can be used to enhance livelihoods, reduce conflict and support local development in rural areas:

1 Jatropha has many medicinal properties: the latex from Jatropha, for example, is used to heal wounds, stop bleeding and to stop pain associated with the stings of bees and wasps; fresh stems are chewed to strengthen gums and treat gum disease; the bark has a purgative effect similar to that of the seeds; the root bark is made into poultices and can be taken internally to expel worms and to treat jaundice; leaves are used against malaria and to treat hypertension; and leaf sap is used externally to treat hemorrhoids (Achten et al. 2007; Brittaine et al. 2010).

2 Parts of the Jatropha plant can be used as a biofertiliser when seed cake or presscake that is left over after pressing the seeds to remove the oil is used as an organic manure, thereby decreasing the need for external fertilisers (Green 2009) while having potentially positive impacts on productivity (Rajagopal 2008). As a caveat, however, the use of the seed cake as a fertiliser in edible crop production raises bio-safety questions given the toxicity of the Jatropha plant (Achten et al. 2004).

3 Jatropha oil can be transformed into soap by adding a solution of sodium hydroxide (caustic soda), and this simple technology has turned soap making into a viable 
small-scale rural enterprise in some areas (Brittaine et al. 2010). The competitiveness of this soap in relation to other commercially prepared soaps is however uncertain.

4 Jatropha leaves and weeded undergrowth can be left on fields as mulch to return nutrients back to the soil (Achten et al. 2007).

5 Jatropha has traditionally been used as a living fence to exclude browsing animals (Achten et al. 2008; Achten et al. 2010).

6 Jatropha oil can be burnt as a local source of energy to provide light and cooking heat. However, the cost of producing this oil may be prohibitive as it is usually much more than the cost of kerosene (or purchased fuelwood) and, even if plant oil can be produced at a comparable price to kerosene, rural people may be reluctant to pay for cooking fuel, be it plant oil, wood or kerosene etc., if any form of biomass can be freely collected (Openshaw 2000).

7 Jatropha can be a source of combustible materials such as using wood from annual pruning and coppicing (Achten et al. 2007), or the seed exocarp, nutshell and kernel (Openshaw 2000). However, some consider the Jatropha wood to be too soft and hollow and therefore not a good fuelwood alternative (Brittaine et al. 2010). It is particularly important to extend research on this front given that, in Indian sites where Jatropha has replaced pigeon peas or cotton, the major livelihood impact (apart from the loss of the food or fiber of the crop) is the loss of fuel (an acre of pigeon peas could provide firewood for six months for an average household of five members) (Ariza-Montobbio et al. 2010b).

8 Jatropha can be useful as a source of sticks or poles, and in some places, the live sticks have been used to support vines such as the vanillin plant, which flowers profusely, drawing bees to pollinate these flowers. By extension, Jatropha can be used to support small-scale apiaries (Openshaw 2000).

\section{Local food security is enhanced and impacts on arable land are minimised}

Jatropha is inedible and thus should not compete with food crops for land. However, there are very real concerns about the impacts of Jatropha cultivation on food security in the developing world. The Food and Agricultural Organization (FAO) defines food security as existing when "all people, at all times, have access to sufficient, safe and nutritious food that meets their dietary needs and food preferences for an active and healthy life" (FAO 2010). Biofuels predominantly impact two dimensions of food security: the availability of food (determined by domestic production, existence of food stocks, etc.) and access to food (depends on poverty, purchasing power, food distribution systems, etc.) (Green 2009).

The availability of food can be directly affected through the production of crops that compete with food crops, such as cash crops for export (e.g., cotton) or crops for the production of biofuels. Therefore, assessments of the impacts of Jatropha cultivation must include consideration for the type of land (arable vs. degraded) that is being used. While it is claimed that Jatropha can be grown on degraded lands, thereby reducing competition with food crops, the reality has been quite different. In Mozambique, Jatropha has been planted as a direct replacement for food crops by subsistence farmers (Ribeiro et al. 2009), while in Tamil Nadu, India, $82 \%$ of 
the interviewed households previously cultivated food crops in the plot on which they began Jatropha cultivation (Ariza-Montobbio et al. 2010b). In the latter case, Jatropha has been competing directly with and replacing groundnut, a food and cash crop and source of edible oil (Ariza-Montobbio et al 2010a). The fact that Jatropha cultivation can reduce production costs serves as an economic incentive to plant the crop on arable land (Green 2009). The generation of income from Jatropha production may, however, also help to improve prospects for food security in a number of ways: farmers will be better able to purchase food on the market, and countries with abundant land area but poor in other natural endowments could pursue new development opportunities (Cotula et al. 2008).

There is a large potential for intercropping Jatropha with other food crops as a means to reduce competition for arable land. Intercropping can help to improve the microclimate, decrease soil erosion and provide humus, helping to revitalise the soil and improving the prospects for food production (Openshaw 2000). In Mali, for examples, biofuel producer Mali Biocarburant requires their farmers to plant Jatropha in rows that are five meters apart with food planted in between (Green 2009). In Honduras, the Gota Verde network does not allow peasants to dedicate their land entirely to the cultivation of Jatropha; instead, they promote Jatropha as living fences and in intercropping plantations with maize and beans (Puente-Rodriguez 2010). Intercropping edible crops with Jatropha should, however, only be recommended during the period before Jatropha starts to bear fruit. This is due to existing concerns about the plant's toxicity (Achten et al. 2008). There have been few studies on intercrop yields, plant spacing or optimal management practices (Brittaine et al. 2010), and the Gota Verde network in Honduras continually re-evaluates their intercropping system to enable new recommendations for planting density, facilitating maintenance of the crop and reducing competition over sunlight (Puente-Rodriguez 2010).

\section{Health risks associated with cultivating and producing Jatropha are minimised}

In spite of its known toxicity, very little information was found in the literature about the health risks associated with Jatropha cultivation, production and usage. The above section discusses the need to exercise caution with respect to the intercropping of food and Jatropha plants. Workers who cultivate Jatropha are in close contact with the seeds, oil and seed cake. They must therefore be cautious as accidental intake cannot be fully excluded, and this is potentially serious given that some studies isolated a tumor-promoting phorbol ester in Jatropha oil (Achten et al. 2007; 2008). There are also questions about the health impacts of burning Jatropha oil as a cooking fuel in closed quarters (Achten et al. 2008). More research must be conducted into the health risks that could arise from Jatropha cultivation and usage.

\section{Local women capitalise on the benefits of Jatropha systems}

A sustainable source of energy could be massively beneficial to rural women in terms of enabling mechanised grinding, rice hulling and water collection, among others, thereby saving women a lot of work and time (Henning 1998). However, there have been accusations that these alternative energy systems are not adequately designed to meet women's needs and priorities. In Tanzania, for instance, cooking stoves based 
on Jatropha oil were more expensive than biogas cookers, both of which were considerably more costly than freely available fuelwood (Van Eijck et al. 2008). In order for Jatropha to be considered a positive contributor to local livelihoods, women must receive benefits from it. One such benefit could arise from the creation of small-scale soap-producing enterprises by rural women to bring in extra income. However, the literature review revealed very little in the way of evidence on the impacts of Jatropha cultivation, processing or usage on rural women in developing countries. Most of the literature was either anecdotal or spoke broadly of the gendered impacts of biofuels. The various interactions between women and Jatropha, both positive and negative, require further investigation. In particular, research is required on whether Jatropha results in women losing their roles as the primary provider of food, and as the crucial reservoirs for indigenous knowledge, when cash crops replace subsistence farming, as has been shown with other biofuels (Asselbergs et al. 2006). Likewise, very little information regarding efforts to build the capacities of both men and women around Jatropha initiatives appeared in the literature; more research in this domain is warranted.

\section{Local people benefit economically from Jatropha}

There are several opportunities for local farmers to benefit economically from Jatropha initiatives, and decentralizing the cultivation and production of the crop could result in more local development. UN Bioenergy recognises that having lots of small-scale producers working together to supply larger facilities, as opposed to having one largescale producer, increases the value-added chain and offers a greater contribution to rural development (UN-Energy 2007). In Mali, Mali Biocarburant has kept every stage of the biofuel production process local and capitalised on employment opportunities: farmers who grow the Jatropha sell the seeds to the local farmers union cooperative, and the farmers union presses the seeds, sells the seedcake back to the farmers, sells the glycerol to a local women's cooperative for soap production, and sells the Jatropha oil to Mali Biocarburant to make the biodiesel and distribute it throughout Mali (Green 2009). This could serve as a model for initiatives elsewhere.

Jatropha plantations have however failed to deliver on the majority of claims made about them, resulting in economic hardship and distress for many small farmers. The literature in this domain indicates that, given its yields, prices and production costs, Jatropha cultivation is not profitable and represents a risky enterprise for smallholders (Ariza-Montobbio et al. 2010b; Brittaine et al. 2010). Jatropha can fail to produce local financial benefits in three ways: requiring long-term and high credit commitments that are not realistic for most smallholders, labour-intensive periods, and increasing land prices beyond what local farmers can afford. Each of these is discussed in turn below.

Given the extensive economic costs including initial investments on land preparation and planting, and the annual maintenance costs for weeding, pruning, fertilisers, pesticides and irrigation, Jatropha crops impose a need for long-term credit on small farmers (Ariza-Montobbio et al. 2010b). Pro-industry policies in Tamil Nadu have meant that companies have more to win than to lose; their timeframes are long and the risks are low in comparison to farmers whose timeframes are driven by shortterm need and face greater risk and uncertainty (especially in light of the fact that the gestation of Jatropha at three to five years is long from the perspective of farmers) 
(Ariza-Montobbio et al. 2010a). This hardship is exacerbated when companies abandon the buyback contracts they signed with Jatropha farmers (Ariza-Montobbio et al. 2010b).

Second, Jatropha has high labour requirements that could offer potential job creation in areas with high unemployment (Achten et al. 2007). In Tamil Nadu, the Jatropha harvest season coincides with the non-agricultural season, thereby supplementing the otherwise season-bound livelihoods with employment during periods when the rest of the crops do not provide income (Ariza-Montobbio et al. 2010a). However, an important contradiction in the discourse on Jatropha has been observed: Jatropha is presented by the government as a source for employment generation in rural areas, yet companies are simultaneously attempting to convince farmers that Jatropha is a good way to cope with the reduced availability of agricultural labourers (Ariza-Montobbio et al. 2010b). Further evidence on the labour requirements and costs of Jatropha cultivation is therefore required.

Finally, pressure in the form of policy and market incentives to turn land over to biofuel production could result in raised land values (Cotula et al. 2008). While beneficial to a lucky few, this could result in the displacement of large numbers of poor people from land.

\section{Institutions developed to enable financing of local Jatropha initiatives}

Several types of local institutions can enable local people to access finance more easily, and hence benefit from Jatropha initiatives. Co-operatives seem to be the most commonly mentioned local institution in the literature. They can improve access to markets because of their increased economies of scale in comparison to individual producers, and reduce costs associated with purchasing the equipment and technology required to press the seeds. Co-operatives can also offer farmers an increase in income by spreading profits throughout the community (Green 2009). They do, however, work best in situations where sufficient commitment from and cooperation by the participants is guaranteed (Asselbergs et al. 2006). The joint venture approach is another type of institution that could be used in Jatropha-related financing. In Namibia's Kavango Biofuel Project, for instance, Jatropha production is to be led by local farmers in collaboration with a Namibian company whereby a joint venture is established to run farming activities: the company holds $60 \%$ of the joint venture's shares while the farmer's association holds the remaining 40\% (Cotula et al. 2008). Families are contracted to grow Jatropha on communal land and contribute both communal land and labour, while the company covers capital costs and compensates participating farmers with food and cash for loss of maize and millet (Cotula et al. 2008). The role of micro-credit appears largely unexplored in the context of Jatropha and was only mentioned in one paper in this review. In this case, one Jatropha-NGO linked to a micro-credit facility provided loans to local farmers in Tanzania (Van Eijck et al. 2008). More research on financial institutions in this domain is thus required.

\section{Technology requirements for Jatropha cultivation and production addressed}

Where Jatropha is being cultivated on a larger scale (as opposed to being grown, for instance, as a living fence), fertiliser and irrigation systems will be required. While 
chemical fertilisers provide some of the important nutrients, Jatropha oil cake and other organic fertilisers can be used to complement these and to provide other nutrients (Asselbergs et al. 2006). There may also be a need for pesticides and insecticides as the incidence of pests and diseases is widely reported under plantation monoculture in spite of claims that pests and disease do not pose a significant threat to Jatropha (Brittaine et al. 2010). Irrigation is a key input for profitable Jatropha cultivation, which automatically excludes the poorest farmers and increases demand for water (Ariza-Montobbio et al. 2010b).

Processing Jatropha involves pressing the seeds in order to expel their oil. This is generally done by means of small manual ram-presses or power-operated screw-presses. Hand presses are better suited for small quantities used in soap production and hence are considered more 'pro poor' (Brittaine et al. 2010). Power-driven presses can handle larger quantities of seeds (Van Eijck et al. 2008). However, they are not successful if they are not affordable and capable of being easily repaired by local artisans (Brittaine et al. 2010). While the technology involved is relatively simple, caution is required on two fronts: first, more attention needs to be given to local production of such equipment or training for modification of existing equipment (Asselbergs et al. 2006); second, because Jatropha is poisonous, many processing firms are unwilling to use the same equipment to press both edible and poisonous seeds, and it may therefore be necessary to develop new oil-expelling facilities that are specifically dedicated to pressing Jatropha seeds (Van Eijck et al. 2008).

Given that about $70 \%$ of the energy consumed in southern Africa is in the form of fuelwood or charcoal (Syampungani et al. 2009), the role that a local and sustainable energy source, such as Jatropha, can play in improving livelihoods in Africa is tremendous. "Energy pervades all aspects of development - it creates healthier cooking environments, extends work and study hours through the provision of electric light ... provides power in remote regions to drive cellular communication equipment, and increases labour productivity and agricultural output by making mechanisation possible" (Brittaine et al. 2010: 10). Yet, there appears to be a wide gap in knowledge about how effectively Jatropha can meet local energy needs given that the use of Jatropha oil requires modified engines, stoves and lamps. A lister-type diesel engine is designed to run on pure plant oil using simple technology that can be repaired by local engineers with rudimentary facilities, while Jatropha-oil burning stoves and lamps need further improvement before widespread acceptance can be expected (Brittaine et al. 2010). While maximizing the rural development potential of Jatropha, the viability of domestic energy solutions using Jatropha remains questionable as it may not be competitive at household or community levels when economies of scale and transaction costs are taken into account (Sulle et al. 2009).

\section{Impacts of Jatropha on Water Resources Minimised}

It is important to understand the implications of development and/or industrial projects on natural resources as developmental processes and human health gains are dependent on ecosystem services (Costanza et al. 1997; Daily 1997). There are growing health implications of environmental degradation (Tabor 2002), and global environmental changes pose various risks to the health of human populations (McMichael 2002). However, the delineation of land for biofuel cultivation is a non-trivial task; all land 
plays a role in the socio-ecosystem, and its conversion to Jatropha production could have economic, social, biodiversity and environmental impacts (Jingura 2011).

There are a number of interactions between Jatropha and the water resources at any given site. Jatropha cultivation can have positive impacts with regard to water resources, though these appear to be related to small-scale cultivation, particularly as hedges, rather than at a plantation scale. It is postulated that small-scale Jatropha projects can improve the water balance of a site, including more levelled flows in rivers and streams, through increased evapotranspiration and erosion control, causing a reduction of surface runoff and a higher infiltration capacity (Asselbergs et al. 2006; Achten et al. 2007).

Additionally, however, there are several pressing concerns about the impacts of large-scale Jatropha projects on the water balance of a site. Assessments have shown that the yield of nuts per plant is much greater in irrigated plots than rain-fed plots. This is due in large part to the fact that continuous irrigation determines the number of fruiting periods per year (Ariza-Montobbio 2010a; 2010b). Jatropha plantations therefore have a much higher water footprint than other crops like soybean, sugarcane or maize (Achten et al. 2007). Bearing the importance of irrigation to higher yields in mind, Jatropha could also bias larger-scale production with irrigation infrastructure over small and marginal farmers (Ariza-Montobbio et al. 2010a). Moreover, the use of methanol in biodiesel production process presents further concerns about the possibility of potable water pollution from large biodiesel production (Brittaine et al. 2010). Additional inquiry into the relationship between Jatropha and water resources is therefore needed.

\section{Impacts of Jatropha on Marginal and Forest Land Minimised}

Both marginal land and forests can be important to rural farmers in developing countries, and Jatropha can have an impact on both. With regard to marginal or wasteland, how land qualifies as idle, barren, under-utilised, unproductive, degraded, abandoned or marginal is often politically charged and poorly defined despite the fact that these terms refer to land that provides vital resources for poorer and more vulnerable groups (Cotula et al. 2008; Ariza-Montobbio et al. 2010b). Common property resources defined in this manner often supply important livelihood commodities such as food, fuel, wood, fodder, timber and thatching material for homes and roofing (Rajagopal 2008). Yet the seizure of land from common property regimes is often done in spite of insufficient data regarding the productivity of Jatropha under sub-optimal and marginal conditions (Jongschaap et al. 2007).

Forest lands, like marginal lands, can also be negatively affected by Jatropha. Forest cover has been replaced by other cash crops around the world. For instance, palm oil, another biofuel plant, has resulted in the clearance of 18 million ha of primary forest cover in Indonesia (Cotula et al. 2008). Although it is not yet clear what the impacts of Jatropha on forests might be, it is unreasonable to assume that Jatropha biofuels as an energy source will curtail deforestation. While the collection of firewood results in forest degradation but not in large-scale deforestation (Openshaw 2000), it is ironically agriculture in the vein and scale of Jatropha plantations that is responsible for much tropical deforestation. Further assessments of the impact of Jatropha on forests should also include a focus on changes in biodiversity. 


\section{I0.3 WHAT SCOPE FOR REDUCING CONFLICTS AND ENHANCING COOPERATION ON JATROPHA-RELATED PROJECTS?}

Three key lessons were learned from case study research on large scale Jatropha projects in Ghana and Ethiopia: local consultation about potential biofuel projects is imperative, land alienation and decreases in the size of household landholdings must be minimised or mitigated, and Jatropha must have positive household-level socio-economic impacts (Timko et al. 2013). These three lessons form the basis of the analytical framework for assessing the impacts of Jatropha on local livelihoods that has been presented in this chapter. An extensive literature search helped to identify and refine the indicators listed in the framework (Table 10.1).

It is imperative that Jatropha projects contribute positively to local livelihoods in light of the projected expansion of Jatropha cultivation across the tropics and the conflicts that have arisen from some Jatropha initiatives. Conflicts have arisen in some instances where the crop has been falsely promoted using a number of dubious claims. According to these claims, Jatropha will enhance socio-economic development while reclaiming marginal and degraded lands; is drought tolerant; is a high yielding crop; grows well under saline conditions; and does not compete with food production. Conflicts have also arisen when communities have not benefited from Jatropha production, and when they have been actively excluded from using land and its resources.

There is ample scope for reducing conflicts and engendering cooperation around Jatropha-related projects in ways that enhance livelihood strategies in rural households in developing countries. This can be attained by, for example, ensuring that by-products obtained from Jatropha are used locally for development, by ensuring that the biofuel does not threaten local food security by avoiding negative impacts on the production of fodder for livestock and intercropping Jatropha with food crops wherever possible, by minimizing health risks associated with the cultivation and production of Jatropha, and by meeting the Jatropha-related knowledge and information needs of local farmers. The potential for Jatropha as a local energy source in Africa is enormous, yet there is at present a knowledge gap about how effectively Jatropha can actually meet local energy needs. A good starting point would be to guaranteeing that the various technology requirements for Jatropha cultivation, production and usage are met in ways that benefit livelihoods. This would include local provisioning of fertilisers and irrigation for the cultivation of the plant, presses for producing the oils, and modified engines, stoves and lamps for using the oil.

The potential livelihood benefits of Jatropha are apparent and can be enhanced provided that women can capitalise on the benefits of Jatropha systems, processes emerge to resolve conflicts and enhance participation around Jatropha initiatives, and decentralised approaches enhance local benefits from Jatropha systems. Likewise, Jatropha initiatives can contribute positively to building local financial capital if they guarantee local people benefit economically from Jatropha, and local institutions are developed to enable the financing of local Jatropha initiatives. Finally, Jatropha can help maintain natural resources if the impacts of the crop on both water resources and marginal and forest land is minimised, and traditional access to land for local people is maintained. 
While the package of criteria and indicators for assessing the impacts of Jatropha on rural livelihoods that has been presented in this chapter may appear daunting when taken together, this list is neither an exhaustive inventory of all potential criteria and indicators that could be used, nor is it a standard checklist to be applied in all situations. Rather, it is to be taken as a starting point for open discussions between all actors involved in Jatropha-related projects: government, company representatives, landowners, traditional authorities and local communities. Each of these groups will inevitably have different views as to which are the highest priority indicators. The conflicts between these priorities can therefore be highlighted, and trade offs and choices made between them can be made more explicit (Scoones 1998). This process of dialogue and negotiation would ideally enable opportunities for cooperation to be made explicit too.

\section{ACKNOWLEDGEMENTS}

Funding for the development of this chapter was provided by the Conflict and Cooperation over Natural Resources in Developing Countries (CoCooN) programme of The Netherlands Organisation for Scientific Research (NWO).

\section{REFERENCES}

Acheampong, E. 2013. The effects of biofuel feedstock production on farmers' livelihoods in Ghana: The case of Jatropha curcas. Unpublished paper.

Achten, W. M. J., E. Mathijs, L. Verchot et al. 2007. Jatropha biodiesel fuelling sustainability? Biofuels, Bioproducts and Biorefining 1: 283-291.

Achten, W. M. J., L. Verchot, Y. J. Franken et al. 2008. Jatropha bio-diesel production and use. Biomass and Bioenergy 32: 1063-1084.

Achten, W. M. J., W. H. Maes, R. Aerts et al. 2010. Jatropha: From global hype to local opportunity. Journal of Arid Environments 74: 164-165.

Amsalu, A., and M. Kinfu. 2013. The socio-economic implications of industrial biofuel development in Ethiopia. Unpublished paper.

Ariza-Montobbio, P., S. Lele, G. Kallis, et al. 2010a. The political ecology of Jatropha plantations for biodiesel in Tamil Nadu, India. Journal of Peasant Studies 37: 875-897.

Ariza-Montobbio, P. and S. Lele. 2010b. Jatropha plantations for biodiesel in Tamil Nadu, India: Viability, livelihood trade-offs, and latent conflict. Ecological Economics 70: 189-195.

Asselbergs, B., J. Bokhorst, R. Harms et al. 2006. Size does matter: The possibilities of cultivating Jatropha curcas for biofuel production in Cambodia. Expertise Centrum voor Duurzame Ontwikkeling: Universiteit Van Amsterdam.

Brittaine, R. and N. Lutaladio. 2010. Jatropha: A Smallholder Bioenergy Crop. Integrated Crop Management, Vol. 8. IFAD/FAO: Rome.

Chambers, R. and G. Conway. 1992. Sustainable Rural Livelihoods: Practical Concepts for the 21st Century, Discussion Paper 296. Institute of Development Studies, Brighton, UK.

Costanza, R., R. D'Arge, R. de Groot et al. 1997. The value of the world's ecosystem services and natural capital. Nature 387: 253-261.

Cotula, L., N. Dyer, and S. Vermeulen. 2008. Fuelling Exclusion? The biofuels boom and poor people's access to land. IIED: London.

Daily, G. 1997. Nature's Services: Societal Dependence on Natural Ecosystems. Island Press: Washington, DC. 
Food and Agriculture Organization. 2010. The State of Food Insecurity in the World: Addressing food insecurity in protracted crises. FAO: Rome.

Franken, Y. J. 2009. FACT Position Paper Food Fuels. FACT Foundation: Eindhoven. http://www.jatropha.de/documents/FACT\%20Position \% 20Paper \% 20Food\%20Fuels.pdf (accessed November 12, 2012).

Gebremedhine, B. 2008. Agrofuels Beyond the Hype: Lessons and Experiences from other Countries. In Agrofuel Development in Ethiopia: Rhetoric, Reality and Recommendations, ed. T. Heckett, and N. Aklilu, 67-82. Forum for Environment in partnership with Horn of Africa Regional Environmental Center/Network (HOAREC/N) and Heinrich Boell Stiftung (HBS).

Green, L. 2009. Jatropha as Biofuel: An Analysis of the Possible Implications for Food Security in Mali. Honours thesis. Dalhousie University.

Henning, R. K. 1998. Use of Jatropha curcas L. (JCL): A household perspective and its contribution to rural employment creation. Paper presented at the "Regional Workshop on the Potential of Jatropha Curcas in Rural Development \& Environmental Protection,” Harare, Zimbabwe, May 1998. http://www.jatropha.de/harare98.htm (accessed October 28, 2012).

Henning, R. K. 2004. "The Jatropha System" - Economy \& Dissemination Strategy. Paper presented at the "International Conference Renewables," Bonn, Germany, June 2004. http://www.jatropha.de/.../JCL-economy-strategy-renewables2004.pdf (accessed September 7, 2012).

Jingura, R. M., R. Matengaifa, D. Musademba et al. 2011. Characterisation of land types and agro-ecological conditions for production of Jatropha as a feedstock for biofuels in Zimbabwe. Biomass and Bioenergy. doi: 10.1016/j.biombioe.2011.02.004

Jongschaap, R., W. Corre, P. Bindraban et al. 2007. Claims and Facts on Jatropha curcas L: Global Jatropha curcas evaluation, breeding and propagation programme. Report 158. Plant Research International B.V: Wageningen.

KnowGenix. 2007. Sustainable Biodiesel Feedstock: Jatropha: A Strategic Option. http://www.knowgenix.com/release/Jatropha_PP1_Nov_07.pdf (accessed September 6, 2012).

McMichael, T. 2002. The Biosphere, Health, and "Sustainability." Science 297: 1093.

Mutch, T. 2010. Jatropha biofuels: the true cost to Tanzania. http://www.theecologist.org/ trial_investigations/414648/jatropha_biofuels_the_true_cost_to_tanzania.html (accessed September 6, 2012).

Openshaw, K. 2000. A review of Jatropha curcas: an oil plant of unfulfilled promise. Biomass and Bioenergy 19: 1-15.

Puente-Rodriguez, D. 2010. Biotechnologizing Jatropha for local sustainable development. Agriculture and Human Values 27: 351-363.

Rajagopal, D. 2008. Implications of India's biofuel policies for food, water and the poor. Water Policy 10: 95-106.

Rakodi, C. 1999. A Capital Assets Framework for Analysing Household Livelihood Strategies: Implications for Policy. Development Policy Review 17: 315-342.

Ribeiro, D. and N. Matavel. 2009. Jatropha! A socio-economic pitfall for Mozambique. Justice Ambiental \& Uniao Nacional de Camponeses. http://www.swissaid.ch/global/ PDF/entwicklungspolitik/agrotreibstoffe/Report_Jatropha_JA_and_UNAC.pdf (accessed November 6, 2012).

Scoones, I. 1998. Sustainable Rural Livelihoods: A Framework for Analysis. IDS Working Paper 72. Brighton.

Sulle, E. and F. Nelson. 2009. Biofuels, land access and rural livelihoods in Tanzania. IIED: London.

Syampungani, S., P. W. Chirwa, F. K. Akinnifesi et al. 2009. The miombo woodlands at the cross roads: Potential threats, sustainable livelihoods, policy gaps and challenges. Natural Resources Forum 33: 150-159. 
Tabor, G. M. 2002. Defining conservation medicine. In: Conservation Medicine: Ecological Health in Practice, ed. A. A. Aguirre, R. S. Ostfeld, G. M. Tabor et al., 8-16. Oxford: Oxford University Press.

Timko, J. A., A. Amsalu, E. Acheampong, et al. 2013. A comparative socio-economic impact assessment of industrial Jatropha (Jatropha curcas) and Castor (Ricinus communis) plantations on households in Ghana and Ethiopia. Unpublished paper.

UN-Energy. 2007. Sustainable Bioenergy: A Framework for Decision Makers. http://esa.un.org/unenergy/ (accessed September 15, 2012).

Van Eijck, J. and H. Romijn. 2008. Prospects for Jatropha Biofuels in Developing Countries: An Analysis for Tanzania with Strategic Niche Management. Energy Policy 36: 311-325.

Weyerhauser, H., T. Tennigkeit, S. Yufang et al. 2007. Biofuels in China: An Analysis of the Opportunities and Challenges of Jatropha Curcas in Southwest China. ICRAF Working Paper Number 53. Beijing, China. 



\title{
Challenges in the design of a research and development programme on conflict and cooperation over natural resources
}

\author{
Jan Joost Kessler I, Han van Dijk ${ }^{2} \&$ Wijnand van IJssel ${ }^{3}$
}

\begin{abstract}
Two Dutch agencies, one responsible for research (NWO/WOTRO) and the other for international cooperation (MoFA/DGIS), recently established a new knowledge, research and innovation programme in the area of 'Conflict and Cooperation over Natural Resources', otherwise known as CoCooN. The first set of projects funded by CoCooN is currently underway. This chapter elaborates on the approaches pursued, the design process and the structure of the programme, which aims to contribute to innovation in science as well as developing policy and practice. The authors highlight considerations, expectations and principles, describing the programme's strategic value of creating linkages between different types of knowledge, formal and informal, based on the science and development practice that originates from scientific institutions and development agencies. One expectation is the capacity to better shape the collaboration between research institutions, non-governmental organisations and public institutions, and to do so on equal footing. Other expectations are to put in place functional mechanisms enhancing responsiveness to policy demands, improving knowledge sharing and capacity development (at project and programme level), and strengthening communication and stakeholder engagement. The authors discuss these expectations and related design principles based on preliminary experiences within the programme.
\end{abstract}

Keywords Conflict, natural resources, knowledge, innovation, science, development relevance.

\section{II.I INTRODUCTION}

Two sectoral agencies within the Netherlands have taken the initiative to develop a new funding approach for the effective generation and use of knowledge for development. One of these is the Directorate General of International Cooperation of the Ministry of Foreign Affairs (MoFA-DGIS). In 2006, the Directorate developed a 'knowledge,

\footnotetext{
${ }^{1}$ Aidenvironment, Amsterdam (Corresponding author: kessler@aidenvironment.org).

${ }^{2}$ Senior Policy Officer, Netherlands Organisation for Scientific Research, WOTRO Science for Global Development (NWO/WOTRO).

${ }^{3}$ Directorate General of International Cooperation of the Ministry of Foreign Affairs (MoFADGIS).
} 
innovation and research strategy' that aims to (further) integrate knowledge management and research into the Ministry's development policies and programmes (Ministry of Foreign Affairs 2006). The formulation of this strategy was based on the recognition that poverty reduction and the attainment of the Millennium Development Goals (MDGs) require policy innovation and continuous learning. The other initiating agency is the Netherlands Organisation for Scientific Research (NWO), funding top researchers at universities and institutes, with NWO-WOTRO as the executing division. In 2006, this division was renamed as WOTRO Science for Global Development, and it has since focussed on research for development.

In 2007, mutual interests came together in the field of Conflict and Natural Resources, a priority area in the NWO Conflict \& Security research programme, as well as a priority theme in the Environment and Water Department of the MoFADGIS. This department had elaborated a specific knowledge, innovation and research strategy with the following stated objectives: "To promote innovation in policies and programmes in the field of environment and water that will contribute to poverty reduction and to the achievement of the Millennium Development Goals; and to strengthen institutional capacity to this end in developing countries" (Ministry of Foreign Affairs 2006). The mid-term ambitions were to strengthen knowledge management within the department and the involved embassies, to invest strategically in relevant research, to utilise and direct the available knowledge and capacities towards innovation in policies and programmes, and to assure high-quality implementation and impact. Under the first DGIS policy objective, 'Enhanced security and stability by combating environmental degradation and the destruction of ecosystems', 'Environment and Conflict' was identified as a key area for knowledge management, research and innovation.

The close collaboration with the MoFA-DGIS offered NWO-WOTRO the opportunity to develop a new funding model for research relevant to development. WOTRO had already explored pathways within NWO's standard frame by renewing its funding schemes, such as the Integrated Programmes (call for proposals for integrated programmes 2006-2007) in which interdisciplinarity and stakeholder involvement were introduced as new key features to enhance the relevance and use of research results. The challenge consequently was to further emphasise development relevance, and explore and enhance more transdisciplinary approaches, all the while assuring scientific rigour.

The programme, 'Conflict and Cooperation over Natural Resources in Developing Countries' (in short CoCooN), was developed through a stepwise process. The first step was a workshop in which a range of both northern and southern researchers and other stakeholders in this knowledge area participated. Priorities were defined on the basis of a review of recent policy initiatives on the environment and conflict nexus, as well as conceptual and theoretical debates in the academic literature (Frerks 2007). Best practices in conducting research for development were also collected. The result was a new proposal for a knowledge, innovation and research strategy. In 2009, NWO and the MoFA agreed on the principles of the new funding programme, as laid down in the background document that was developed with inputs from a selected group of workshop participants who served as a reference committee (Netherlands Organisation for Scientific Research 2008). This formed the basis for a competitive call for proposals, in which the aforementioned principles were translated into concrete requirements for submitted applications, and criteria for approval and selection (Netherlands Organisation for Scientific Research 2009). 
The thematic area of 'conflict over natural resources' is complex; it has to deal with (i) the positive as well as negative functions of conflict; ii) the dynamic and longitudinal nature of conflict; iii) influences across different levels of scale; and (iv) the involvement of multiple actors and causes (Netherlands Organisation for Scientific Research 2007). Moreover, such conflicts often have intricate political and institutional dimensions. It is therefore expected that new types of knowledge, trans-disciplinary research, and synergy between research and non-research institutions and stakeholder engagement will be particularly relevant for this thematic area. The programme draws on recent concepts and approaches as developed or described by, for example, ODI-RAPID (ODI 2004) and the International Development Research Centre (IDRC). ${ }^{4}$

The programme explicitly includes attention for cooperation over natural resources as the alternative option to conflict in order to emphasise the focus of the programme on concrete impacts and a positive contribution to development.

The overall objective of the programme is to contribute to evidence-based policy development and practice in the field of conflict and cooperation over natural resources, and to adequately manage, resolve and learn from conflicts over natural resources. This objective was divided into three distinct sub-objectives, to contribute to:

1 Providing society with tools and perspectives for evidence-based policy development and practice in developing countries-the Development perspective.

2 Generating knowledge, high quality research and innovation in the field of conflict and cooperation over natural resources-the Knowledge, research and innovation perspective.

3 Capacity building of organisations, groups and individuals, including researchers, policy makers and other stakeholders at different levels-the Capacity development perspective.

The following section elaborates on the organisation and the expectations of this new programme, as well as the structure and approaches that were adopted. In the subsequent section, some initial observations are presented on whether and how these approaches work in practice.

\section{II.2 ORGANISATION, EXPECTATIONS AND DESIGN PRINCIPLES}

\section{II.2.I Organisation}

Based on general NWO principles, different bodies were assigned the tasks of decisionmaking and providing advice on the new research programme. Decision-making was assigned to a Steering Committee composed of representatives of the funding agencies. Advice was assigned to an International, non-Dutch Advisory Committee. Both governing bodies included members from academia, practice and policy.

Decision-making was especially important in the process of awarding the proposals. From a total of 43 submitted preliminary proposals, 7 were awarded after a

\footnotetext{
${ }^{4}$ http://www.idrc.ca/EN/Programs/Social_and_Economic_Policy/Peace_Conflict_and_Development/, viewed August 2011
} 
competitive procedure that included a preliminary and final proposal stage, as well as peer reviews.

\section{II.2.2 Design of the programme}

The steering committee proposed a set of guiding principles for the design of the programme. They are as follows:

- Demand-driven priorities for knowledge, research and innovation

- Practical use of the research findings

- High scientific quality

- Linkages to on-going regional or thematic programmes

- Development of capacity to innovate

Departing from these principles, a set of more specific design principles was developed for CoCooN projects. These design principles are related to and based on eight major expectations of the CoCooN programme and its projects. The eight expectations either refer to procedural aspects of the programme (project management, operational procedures and systems) or to its expected results and impacts (i.e. contents). The design principles, including structural and procedural elements, aim to ensure that these expectations will be met (Netherlands Organisation for Scientific Research 2009). Table 11.1 summarises the eight expectations and the corresponding programme design principles. As stand-alone features, these principles are not unique. However, the combination of these principles within one programme is quite innovative. The expectations and related design principles are elaborated in the following section.

\section{I.2.3 Definition of expectations and related design principles}

Knowledge and knowledge sharing are the focal points of the programme. The assumption is that considerable knowledge on ways of dealing with conflicts and enhancing cooperation is already available. However, this available knowledge needs to be made more accessible. Such knowledge may be contained in research, but it may also exist in non-research institutions (non-research may include civil society, NGOs, government and private sector). Consequently, two expectations emerge from this central focus.

The first expectation is that the programme will create intensive exchange on different types of knowledge and skills by bringing together different types of institutions within one project team. While the integrated programmes of NWO-WOTRO are traditionally led by a (Dutch) research institution, which collaborates with different stakeholders based on relevance and felt needs, CoCooN projects are to be steered and managed by a consortium. A consortium should consist of representatives of at least four different institutions (or project partners): (i) a southern-based research institute; (ii) a northern-based research institute; (iii) a southern-based non-research institute; and (iv) a northern-based non-research institute. Non-research institutes may include organisations ranging from governmental to non-governmental and private sectors. Given this setting of different knowledge based institutions united within one project, it is expected that the emergent internal project dynamics are aimed at sharing and 
Table II.I Main expectations, related programme design principles and preliminary observations on progress.

\begin{tabular}{|c|c|c|}
\hline Expectation & Design principle & Preliminary observations \\
\hline $\begin{array}{l}\text { I. Creating } \\
\text { intensive } \\
\text { exchange } \\
\text { between } \\
\text { various } \\
\text { sources of } \\
\text { knowledge }\end{array}$ & $\begin{array}{l}\text { - Consortium with different } \\
\text { institutions in each project } \\
\text { - Project management on } \\
\text { an equal footing } \\
\text { - Internal project dynamics } \\
\text { and budget for joint } \\
\text { events }\end{array}$ & $\begin{array}{l}\text { - Project consortia meet requirements } \\
\text { - Hardly any governmental and no private } \\
\text { sector partners involved } \\
\text { - Frequent exchange events within teams } \\
\text { - Bridging the traditional divides between } \\
\text { academics and civic partners takes time }\end{array}$ \\
\hline $\begin{array}{l}\text { 2. Making } \\
\text { existing } \\
\text { knowledge } \\
\text { available and } \\
\text { new types of } \\
\text { knowledge } \\
\text { emerge }\end{array}$ & $\begin{array}{l}\text { - Review to aggregate } \\
\text { existing knowledge as } \\
\text { a start } \\
\text { - Gap analysis (continuous) } \\
\text { - Transdisciplinary focus } \\
\text { - Variety of research forms } \\
\text { (fundamental - fast track) }\end{array}$ & $\begin{array}{l}\text { - Numerous stakeholder meetings/workshops } \\
\text { - Promising reviews done, some to be } \\
\text { published or stored in d-bases } \\
\text { - New approach for conducting research on } \\
\text { the interface of research and development } \\
\text { reported once } \\
\text { - High output level, also in non-academic } \\
\text { domains (e.g. manuals, tools) } \\
\text { - Unclear to what extent output is shared } \\
\text { with a larger community }\end{array}$ \\
\hline $\begin{array}{l}\text { 3. Synergy } \\
\text { between } \\
\text { three sub- } \\
\text { objectives/ } \\
\text { dimensions }\end{array}$ & $\begin{array}{l}\text { - Activities and targets } \\
\text { for each dimension } \\
\text { - Added value by synergy } \\
\text { between dimensions }\end{array}$ & $\begin{array}{l}\text { - Research has the highest priority in this } \\
\text { starting phase } \\
\text { - Compulsory indicators defined for each } \\
\text { dimension } \\
\text { - Log frames revised and detailed }\end{array}$ \\
\hline $\begin{array}{l}\text { 4. Local } \\
\text { demand } \\
\text { articulation } \\
\text { and } \\
\text { ownership }\end{array}$ & $\begin{array}{l}\text { - Local demand articulation } \\
\text { based on good problem } \\
\text { and context analysis } \\
\text { - Stakeholder engagement } \\
\text { and communication } \\
\text { - Flexible budgets to } \\
\text { address emerging issues }\end{array}$ & $\begin{array}{l}\text { - Specific and geographical focused themes } \\
\text { have emerged } \\
\text { - Stakeholder participation in project } \\
\text { activities is a common practice, but } \\
\text { engagement takes more time to get going }\end{array}$ \\
\hline $\begin{array}{l}\text { 5. Uptake of } \\
\text { results in } \\
\text { policy and } \\
\text { development } \\
\text { practice }\end{array}$ & $\begin{array}{l}\text { - Involvement of policy } \\
\text { makers } \\
\text { - Communication on } \\
\text { output dissemination } \\
\text { - Different types of outputs }\end{array}$ & $\begin{array}{l}\text { - Policy makers not (yet) involved in most projects } \\
\text { - In some cases interests of policy makers } \\
\text { raised by early communications } \\
\text { - Several requests for advice from policy makers }\end{array}$ \\
\hline $\begin{array}{l}\text { 6. Capacity } \\
\text { development } \\
\text { as a focus, not } \\
\text { only oriented } \\
\text { at research } \\
\text { skills }\end{array}$ & $\begin{array}{l}\text { - Capacity development } \\
\text { worked out in broad } \\
\text { terms, with targets, } \\
\text { including communication, } \\
\text { knowledge management. } \\
\text { - On-the-job training }\end{array}$ & $\begin{array}{l}\text { - So far focus on research skills (e.g. } \\
\text { involving -mainly Dutch- Master students, } \\
\text { transdisciplinary research training), as well as } \\
\text { consortium and team building (e.g. on } \\
\text { leadership, empowerment) } \\
\text { - Capacity building among / with stakeholders } \\
\text { mostly foreseen for later stages }\end{array}$ \\
\hline $\begin{array}{l}\text { 7. Learning } \\
\text { within the } \\
\text { programme }\end{array}$ & $\begin{array}{l}\text { - Events to stimulate } \\
\text { exchange at programme } \\
\text { level } \\
\text { - Linkages to networks, } \\
\text { platforms and } \\
\text { programmes } \\
\text { - Communication on } \\
\text { international } \\
\text { collaboration }\end{array}$ & $\begin{array}{l}\text { - Some joint activities and events organised at } \\
\text { the level of the programme (kick-off, working } \\
\text { on joint academic publication) but not (yet) } \\
\text { focused at learning } \\
\text { - Joint web-based workspace constructed, } \\
\text { more intensively used for project communication } \\
\text { and less for exchange at the programme level }\end{array}$ \\
\hline $\begin{array}{l}\text { 8. Communication } \\
\text { as a } \\
\text { cross-cutting } \\
\text { focus }\end{array}$ & $\begin{array}{l}\text { - Communication strategy } \\
\text { - Budget for } \\
\text { communication activities }\end{array}$ & $\begin{array}{l}\text { - Communication strategies designed } \\
\text { - Communication in some cases already taken up } \\
\text { - Ut early stages } \\
\text { - Co of new media reported } \\
\text { - Communication mainly one-way (not feed-back } \\
\text { or debate oriented) }\end{array}$ \\
\hline
\end{tabular}


combining knowledge. Thus, knowledge generation, research and innovation are seen as continuous and iterative processes.

The second expectation is that new types of knowledge will emerge as a result of the synergy between different types of institutions and disciplines, as well as the inclusion of northern and southern institutions within one project. New types of knowledge are expected to be the result of transdisciplinary approaches, and may consist of a new combination of procedural and analytical tools (e.g. combinations of stakeholder engagement, actions, communication, feed-back and analysis). To get started, each project holder is recommended to make an overview of existing knowledge, draw conclusions, stimulate feedback and identify gaps. This is expected to generate added value in terms of new knowledge generated. The quality of the transdisciplinary approach is an important criterion for the appraisal of project proposals. The use of a variety of research tools is recommended. The programme also allows for different types of research styles, ranging from fundamental (long-term) to fast-track (short-term) studies. These respond to and match different types of policy demands and policy processes. Fast-track research will basically be oriented towards making existing knowledge available for concrete short-term policy requests. Output dissemination is also one component of the CoCooN communication strategy (Table 11.1).

The third expectation is related to the three sub-objectives of the programme. It is expected that added value will emerge by giving importance to, and creating linkages between the dimensions of: development (in policy and practice); knowledge, research and innovation; and capacity development (both of internal project staff and external stakeholders). This aspect is elaborated in the programme structure by defining expected results and indicators for each of these sub-objectives (or dimensions). In appraising project proposals, equal importance is given to the three sub-objectives and the synergy between them. The challenge is to ensure that project partners also respect this balance throughout the programme's implementation. This requires careful management of each project in order to shape the collaboration between research institutions, non-governmental organisations and public institutions, on equal footing, and avoid situations in which one project consortium partner overrules the others.

The fourth expectation is that projects will identify and focus on problems and themes that are relevant for an adequate response to concrete local demands from policy or practice. Project partners will thus require good problem and context analyses, but also continuous stakeholder engagement and feedback on preliminary project findings. After all, these demands may change over time. The assumption is that alignment with local demands will enhance the use of the project's knowledge by policy makers and other development agents. This aspect has been emphasised in the call for proposals. To enhance demand articulation, ownership and the effective use of results, relevant stakeholders are expected to engage in all phases of the project, from its inception to sharing the results that emerge. Such engagement must be demonstrated in reference to involvement in project preparation, letters of support and linkages to ongoing projects, private enterprises, policy implementation or stakeholder processes. The communication strategy employed by project partners should aim for stakeholder involvement (see below) and continuous interaction between the project and stakeholders. Relevance is enhanced by the fact that project budgets are not allocated for a 5 -year period, but instead only for 2 years. Once the two-year period has elapsed if results and relevance can be demonstrated - additional funding may be acquired. 
Moreover, the funding should be seen as a contribution to the total expected project costs, and it is expected that projects search for and receive additional funding from other interested parties.

The fifth expectation is that the projects will have real impacts on policy and practice. For most research oriented projects, the final objective stops short at the generation of knowledge and the improved understanding of a topic. It is assumed that the research findings will gradually trickle down to policy makers and other development agents. The CoCooN call for proposals, however, asks for explicit outcomes and targets at the level of development and policy change (change of behaviour, adoption of new practices, adjustment of policies, etc.). To ensure these results, active involvement of relevant policy makers and development agents in the design and execution of the project is needed from the earliest phases and onwards. For projects to be able to provide appropriate and timely inputs to bringing about policy changes, it also requires that project partners understand the dynamics and logic of relevant policies.

The sixth expectation refers to capacity development of the research institutions and non-research institutions involved. The capacities aimed for do not only include research skills, but capacities such as knowledge sharing and accessing, as well as communication between research and non-research institutions. It is assumed that in order to have an impact on conflict and cooperation regarding natural resources, knowledge management skills are critical, as are communication and collaboration skills. Capacity development in these fields was expected to not only emerge through training, but additionally, in fact primarily, through 'learning by doing'. This aspect is elaborated as part of the third sub-objective (outputs and outcomes), with explicit requirements to elaborate on capacity building aspects beyond research capacities.

The seventh expectation is that of learning and sharing of experiences beyond the individual projects, at the level of the CoCooN programme (between the individual projects), as well as at regional and international levels, and between the projects and other relevant institutions. The proposals are required to mention the linkages with other relevant international networks, platforms or programmes, and demonstrate how results would feed into these. It is expected that the projects also initiate new ways of learning and regional exchange in order to share findings. This aspect is further addressed as one component of the communication strategy, that of international collaboration (see below).

The eighth expectation is that communication is managed as a cross-cutting focus within each CoCooN project. Each project proposal was therefore required to contain a communication strategy, including communication objectives, products and means of communication. The strategy distinguishes between (i) stakeholder involvement, (ii) international collaboration, and (iii) output dissemination. Communication is not something to be addressed at the end of the project, as is commonly done, but instead from the very onset.

\section{II.3 INITIAL OBSERVATIONS ON PROGRESS}

We will now discuss the extent to which the design principles have been put in practice in order to meet the set expectations and the extent to which these have been implemented thus far. This discussion is based on initial project proposals, as well as the 
Table II.2 Overview of the 7 CoCooN projects and consortia (leadership is underscored).

\begin{tabular}{|c|c|c|c|c|}
\hline \multirow[b]{2}{*}{$\begin{array}{l}\text { Project and } \\
\text { subject }\end{array}$} & \multicolumn{4}{|c|}{ Composition and leadership } \\
\hline & $\begin{array}{l}\text { South } \\
\text { research }\end{array}$ & $\begin{array}{l}\text { North } \\
\text { research }\end{array}$ & $\begin{array}{l}\text { South } \\
\text { non-research }\end{array}$ & $\begin{array}{l}\text { North } \\
\text { non-research }\end{array}$ \\
\hline $\begin{array}{l}\text { I. Small-scale } \\
\text { gold mining }\end{array}$ & $\begin{array}{l}\text { Univ. Federal de } \\
\text { Pará, Brazil }\end{array}$ & $\begin{array}{l}\frac{\text { Centre for }}{\text { Latin American }} \\
\frac{\text { Research \& }}{\text { Documentation, }} \\
\text { NL }\end{array}$ & $\begin{array}{l}\text { World Wildlife Fund, } \\
\text { Guiana/Surinam }\end{array}$ & Solidaridad, NL \\
\hline $\begin{array}{l}\text { 2. Jatropha curcas } \\
\text { in rural land use }\end{array}$ & $\begin{array}{l}\text { Addis Ababa Univ., } \\
\text { Ethiopia; Kwame } \\
\text { Nkrumah Univ. of } \\
\text { Science and } \\
\text { Technology, } \\
\text { Ghana }\end{array}$ & $\begin{array}{l}\text { Univ. of British } \\
\text { Columbia, } \\
\text { Canada }\end{array}$ & $\begin{array}{l}\text { Rural Environmental } \\
\text { Care Association, } \\
\text { Ghana }\end{array}$ & Both Ends, NL \\
\hline $\begin{array}{l}\text { 3. Groundwater } \\
\text { in the Political } \\
\text { Domain }\end{array}$ & $\begin{array}{l}\text { Mekelle Univ., } \\
\text { Etiopia; Sana’a } \\
\text { Univ.,Yemen }\end{array}$ & $\begin{array}{l}\text { Delft Univ. of } \\
\text { Technology, The } \\
\text { Netherlands }\end{array}$ & $\begin{array}{l}\text { Oromia Water } \\
\text { Works Design and } \\
\text { Supervision } \\
\text { Enterprise, Ethiopia; } \\
\text { Palestinian Water } \\
\text { Authority, Palestine } \\
\text { Territories }\end{array}$ & MetaMeta, NL \\
\hline $\begin{array}{l}\text { 4. Lands and } \\
\text { Rights in } \\
\text { Troubled } \\
\text { Waters }\end{array}$ & $\begin{array}{l}\text { Centro de } \\
\text { Estudios Sociales, } \\
\text { Colombia; Univ. } \\
\text { Federal do Pará, } \\
\text { Brazil }\end{array}$ & $\frac{\text { University of }}{\text { Utrecht, NL }}$ & $\begin{array}{l}\text { CENSAT Agua Viva - } \\
\text { Friends of the Earth, } \\
\text { Colombia; Comissão } \\
\text { Pastoral da Terra, } \\
\text { Brazil }\end{array}$ & $\begin{array}{l}\text { Dutch Section } \\
\text { Foodfirst } \\
\text { Information \& } \\
\text { Action Network, } \\
\text { The Netherlands }\end{array}$ \\
\hline $\begin{array}{l}\text { 5. Nationalisation } \\
\text { of extractive } \\
\text { industries }\end{array}$ & $\begin{array}{l}\text { Universidad San } \\
\text { Francisco de } \\
\text { Quito, Ecuador }\end{array}$ & $\frac{\frac{\text { Institute of }}{\text { Social Studies, }}}{\text { NL }}$ & $\begin{array}{l}\text { League for the } \\
\text { Defense of the } \\
\text { Environment - } \\
\text { LIDEMA, Bolivia }\end{array}$ & $\begin{array}{l}\text { HIVOS,The } \\
\text { Netherlands }\end{array}$ \\
\hline $\begin{array}{l}\text { 6. Land acquisition } \\
\text { and dwindling } \\
\text { water resources }\end{array}$ & Moi Univ., Kenya & $\frac{\text { Africa Studies }}{\text { Centre, NL }}$ & $\begin{array}{l}\text { IUCN-World } \\
\text { Initiative for } \\
\text { Sustainable } \\
\text { Pastoralism, Kenya }\end{array}$ & $\begin{array}{l}\text { Cordaid, The } \\
\text { Netherlands }\end{array}$ \\
\hline $\begin{array}{l}\text { 7. Reincorporating } \\
\text { the excluded in } \\
\text { small-scale } \\
\text { fisheries }\end{array}$ & $\begin{array}{l}\text { Univ. of Cape } \\
\text { Town, South } \\
\text { Africa; Univ. of } \\
\text { Ruhuna, Sri Lanka; } \\
\text { Madras Institute } \\
\text { of Development } \\
\text { Studies, India; } \\
\text { Univ. of Jaffna, } \\
\text { Sri Lanka }\end{array}$ & $\begin{array}{l}\text { University of } \\
\text { Amsterdam, NL; } \\
\text { Univ. of Ulster, } \\
\text { United Kingdom }\end{array}$ & $\begin{array}{l}\text { Masifundise } \\
\text { Development Trust, } \\
\text { South Africa; South } \\
\text { Indian Federation of } \\
\text { Fishermen Societies, } \\
\text { India; National } \\
\text { Fisheries Solidarity, } \\
\text { Sri Lanka }\end{array}$ & Cordaid, NL \\
\hline
\end{tabular}

observations and activities that were reported after the first year of implementation of the CoCooN projects. Table 11.1 (third column) gives a summary of these first observations.

First, we present the CoCooN projects and the consortia that have been formed, with an indication of team composition and leadership. Table 11.2 illustrates how the consortia have been formed around subjects dealing with conflicts and natural 
resources with a multi-disciplinary character, and how academic institutions maintain a leading role in most cases.

Most projects commenced in the last quarter of 2010 or the first quarter of 2011 and have mixed teams of researchers and practitioners (mostly representatives of NGOs). Stakeholders are also involved, with varying levels of engagement. Stakeholders in this case primarily concern civic groups and their representatives (NGOs), while private and governmental sectors appear to be absent (thus far).

In most cases, internal working modalities and communication have developed, although this often took more time to develop and manage than initially expected. This holds true especially for bridging the traditional divide between academics and civic partners. It appears that in some cases expectations differ between project partners, especially with regard to working and research modalities and prioritisation of activities. This may be due to the fact that non-research institutes are not familiar with the way research-funded projects should be run, and research institutes 'naturally' tend to take the lead. This has led to different opinions with regard to the priorities in the implementation of the three sub-objectives (at an 'equal level'). Partly as a response to this, the initiative has been taken up by the programme to define a set of indicators for each sub-objective, with a set of targets and compulsory contributions for each indicator to be achieved by each project. This may help to avoid unjustified bias or priorities in the project implementation, and realise synergy between the three sub-objectives.

Capacity development activities are being carried out in all projects. In most cases, these are still directed at the development of research capacity, for example involving Master students, and focussed on the project teams. Capacity development with and among stakeholders is less common, but some promising examples that could be shared more broadly have emerged. The general attitude is that capacity building can only take place once research results have emerged and insights can be shared.

In many projects, the rather traditional and linear research approach remains predominant. This approach is characterised by the following steps: (i) analysis of the problem, (ii) formulation of research questions and sub-projects, (iii) undertaking the research projects, (iv) analysis of the results, and (v) communicating and disseminating the results. In this model (covering 4-5 years), stakeholders are mostly engaged in order to provide information, and in the last phase are informed about the results (and requested for feed-back) with the expectation that it influences policy and practice. The initial expectation within CoCooN, however, was that more circular and iterative forms of research approaches would emerge. This may be true for two of the seven projects, where we observe a quick first loop based on a review of existing and easily accessible knowledge, communication and some initial uptake. In one case, the review of existing knowledge is upfront and has led to a number of publications and considerable policy advice within one year. In the other cases, communication and policy involvement are upfront, and this has led to various presentations, round tables and visuals, and initial influences on policy-makers. These are indeed new forms of undertaking research. Following this first loop of 'research', we would now expect these projects to start a subsequent loop based on an adjusted demand articulation and new research findings.

Aggregating existing knowledge has a prominent place in most projects. It has, however, only been effectively used in one case, as was expected, and resulted in 
subsequent adjustment or precision of the demands and research priorities to focus upon.

Knowledge sharing has received attention in all projects, with joint workshops and peer-reviews of each of the projects' results and articles. This has reportedly been fruitful and enhanced knowledge exchange, capacity building and mutual understanding. Thus far, exchange events have taken the form of physical meetings, but they could also take the form of teleconferences in order to save time (and carbon emissions). The use of a shared virtual working space is instrumental for some projects.

We do not yet observe the results of transdisciplinary research approaches, whereby different knowledge sources and research methods are integrated instead of being used separately. This may, however, require additional time to develop sufficiently. Promises on innovation in the projects do not refer to new insights in transdisciplinary research methods or approaches to deal with conflicts and cooperation, but rather to new tools or methods within the same research paradigm.

Examples of the uptake of results in policy and practice are present but remain rare, a factor that is not entirely surprising at this early stage of the programme. However, the level of involvement of public sector decision makers is considerably low, and the engagement of this group of stakeholders is perceived as difficult to realise.

Exchange events have been organised at programme level, allowing the projects to share ideas and initial findings. These have been enthusiastically visited, which suggests that a real learning community is developing.

\section{II.4 CONCLUSIONS AND REMAINING CHALLENGES}

In creating a structure and funding modalities that allow consortia with research and non-research institutions to collaborate and share responsibilities and knowledge inputs to work at the interface between research and development objectives, the programme and its seven projects are innovative and ambitious. As far as we know, this level of interaction and transdisciplinarity has not often been realised, and we expect that lessons of broader importance can be derived from this experience. This is ambitious, because it requires both research and non-research institutions to fundamentally change their way of 'doing business'. After all, both types of institutions have very different incentive structures and interest groups to which they are accountable. Universities and individual academics are judged on the basis of their "scientific excellence," which is in turn largely assessed in terms of the number of papers they publish in peer-reviewed journals. These journals look for scientific quality and do not primarily judge on the basis of development relevance. Private sector, civil society and public sector institutions are accountable to the general public, their shareholders or their members, and do not put research quality at the forefront. They usually have legitimate interests to achieve concrete development results and consider good science as helpful if it can help improve the quality of development results, but it is not their first concern. While research institutions tend to adopt a linear process from identification of research questions to acquiring convincing responses over a period of several years, non-research institutions tend to work in a less predictable way. They instead need to rapidly respond to contextual changes and stakeholder opinions to which they are accountable. We therefore believe that one overall challenge is to abandon the tradition 
of working along a linear process, replacing this instead with a process that starts with stakeholder engagement, external communication, testing the first research questions and developing visuals to raise awareness. and in doing so involving a broader set of stakeholders in early stages of the project.

We conclude from the initial overview of progress made that the design of the CoCooN programme, through its eight design principles, has already led to promising signs of new types of internal project dynamics and new emerging forms of knowledge management and research intertwined with development outputs. However, in this initial phase, most project teams are still mainly inward-looking. Most attention goes to issues such as team-building, internal communication, fine-tuning, and developing joint research methodologies and tools.

The following can be highlighted as the main challenges that we see ahead:

1 Development of new research forms, especially short loops that provide knowledge and respond to demands by policy-makers at a short notice

2 Developing research approaches that provide relevant development results (e.g. by undertaking pilots, testing new practices, setting in place information systems, etc.)

3 Flexible management of projects, in terms of research priorities (to respond to new opportunities and changes in local demand) and management (internal communication and additional funding)

4 Ways of improving engagement by policy levels and understanding the policy processes that we aim to influence, both for more concrete demand articulation and uptake of project results

5 Ways to develop wider communication and knowledge sharing (in a cost-efficient way)

6 Internal learning linked to (results generated by a) cost-effective monitoring (both on results and management processes)

7 Communication and stakeholder engagement that are not last steps in a linear process of conducting research, but instead are cross-cutting issues within multiple project loops.

We expect that sharing experiences and lessons learned, especially between and beyond the projects, will be intensified in the near future. This will contribute to the development of innovative knowledge, research and innovation approaches in this difficult and delicate field of study.

\section{REFERENCES}

Frerks G. 2007. Linking Environment and Conflict Building Blocks for a Knowledge, Innovation and Research Strategy. Prepared for the BuZa-NWO workshop on Conflict \& Natural Resources, The Hague - 3 October. NWO/WOTRO, The Hague, Netherlands.

Ministry of Foreign Affairs. 2006. Knowledge, Innovation and Research Strategy (KOS), Environment, Water and Poverty Reduction. Ministry of Foreign Affairs, The Hague, the Netherlands.

Netherlands Organisation for Scientific Research (NWO / WOTRO). 2006. WOTRO Strategy Plan 2007-2010. NWO/WOTRO, the Hague, Netherlands. 
Netherlands Organisation for Scientific Research (NWO / WOTRO). 2007. Startnotitie NWO Conflict \& Veiligheid. NWO/WOTRO, the Hague, Netherlands.

Netherlands Organisation for Scientific Research (NWO / WOTRO). 2008. Conflict and cooperation over natural resources in developing countries. A background document. NWO/WOTRO, the Hague, Netherlands.

Netherlands Organisation for Scientific Research (NWO / WOTRO). 2009. Conflict and Cooperation over Natural Resources in Developing Countries -CoCooN- Call for full proposals. NWO/WOTRO, the Hague, Netherlands.

Overseas Development Institute. 2004. Bridging Research and Policy in International Development. Briefing Paper. ODI, London. 


\section{Subject index}

Action component (perspective), 8

Action research, 8, 92, 102

Alienation, 114, 117, 119, 175, 188

Amazon region, 102, 103, 104, $112,122,130,133,141$

Analytical framework, 110, 112, 175-188

Anocracy, 36, 43

Biodiversity, 52, 65, 98, 104, 155, 174, 187

Biofuel, 2, 4, 8, 29, 59, 173-174, 178, 180-181, 182, 184, 187

Bolivia, 3, 6, 21, 109-125

Brazil, 3, 59, 91, 92, 102-104, 110, 111, $129,131,134,140-144$

Capacity development, 26, 101, 193, 195, 198, 199, 201, 202

Climate change, 2, 13, 15, 17, 21, 27, 36, 73

CoCooN programme, 2, 8-9, 13, 28-30, 68, 72, 193, 196, 198, 199, 200, 203

Collaboration, see cooperation

Collective action, 8, 39, 42, 44, 123, 147, $151,152,165$

Colombia, 3, 4, 27, 91, 92, 101-102, 129, 130, 131, 137-140, 144

Commodity tracking, 26

Commons, 73-75, 160, 163

Communication, 76, 186, 193, 198, 199, 201, 203

Competing claims, 3, 29, 52, 131

Conflict, 1, 3, 5, 13-28, 35-48, 51-68, 72, $75-77,84,96,99,100,102,103$, 123-125, 129, 135, 136, 140, 143, 144, $147,149-151,152-154,156,157,159$, $162,163,166,173,179,188-189$, 193-195

armed, 23, 36, 45, 93 causes, 5, 6, 35, 38-39, 74, 130

civilisational, $35,47-48$

internal, 35, 36, 37, 40, 45, 48, 61

sectarian, 37, 47-48

transboundary, 9, 75, 79

Consultation, 87, 100, 102, 122, 123, 173, $174,175,178,188$

Cooperation, 2, 5, 8, 9, 13, 14, 20, 22, 75, 188, 193

technical, 76

transboundary, 8, 75, 79

Crime

corporate, 25, 92, 93, 95, 102, 104, 105

ecological, 97, 98, 112, 138, 181

environmental, 97

government, 93, 95, 112

organized, 95, 96, 104

state-corporate, 95

Criminology, 93-96

green, 92, 96-98

Development, 1, 2, 13, 15, 17, 20, 26, 37-42, 100, 109, 112, 113, 124, 130, 136, 143, 148, 153, 154, 158, 159, 173, 174, 180, 181-182, 193, 194, 195, 198, 201, 203

policy, 18, 80

practice, 193

Ecuador, 109, 119-125

Entropy, 84-85

Environmental conflict, 17, 27, 29, 45, 52, 101,144

Environmental peace building, 19-20

Ethiopia, 3, 4, 61, 71-88, 173, 175, 178 
Fisheries, 1, 4, 57, 65, 143, 147, 150, 152, $153,154,155,156,158,159,161,164$, $165-166$

industrial (trawl), 7, 29, 148, 156, 157-158, 163

small-scale, 4, 147, 149, 150, 153, 154, $156,157,158,161,163,164$

Ghana, 4, 24, 173, 174, 175, 178, 188

Globalisation, 4, 17, 21, 35, 36, 40-41, 48, $59,99,153$

Gold-mining, 129

large-scale, 91, 121, 137, 138

mechanized, 138, 139, 140, 183

small-scale (artisanal), 129, 130, 131, 133, $134,138,140,143,144$

Governance, 4, 7, 13, 14, 15, 18, 20, 21, 22, $27,29,71,75,82,85,86,95,104,144$, 147-165

interactive, 147, 148, 149, 151, 152

participatory, 4, 147-165

Greed, 6, 15, 16, 39, 43, 56

Grievance, 6, 16, 36, 38, 39, 40, 43, 44, 49,56

Groundwater, 71-86, 88

Gypsum, 2, 3, 52, 63, 67

Harm, 91-104

environmental, 3, 91, 92, 96, 97, 98, 102, 104

human, 98, 104

Identity politics, 6,18

Impact, 173-187

assessment, 182, 187

criteria, 24, 139, 175, 178, 189

indicators, 173, 178, 188, 198, 201

socio-economic, 15, 173, 175, 178, 181

Inequality, 16, 36, 39, 41, 42, 48, 76, 98, 110

Institutions, 13, 19, 21, 22, 29, 35, 39, 43, $49,53,54,71,72,76,95,101,114$, $147,152,160,162,165,185,193,195$, 198, 199, 202

Interdependence, 21-22

Jatropha curcas, 173-189, 200

Justice, 49, 92, 94, 98, 147

environmental, 92, 98

social, 98
Kamba, 63, 64, 67

Kenya, 3, 51, 60, 61, 62, 67, 68

Knowledge

formal, 193

informal, 193

sharing of, 193, 196, 202

Land

agricultural, 59

landholding, 173, 175, 180

sale, 114

use, $28,91-104,140,179-180$

Latin America, 1, 28, 91, 111-113

Law, 4, 6-7, 75, 81, 92, 93, 100, 103, 104, 105, 115, 116, 120, 131, 136, 137, 143-144, 149, 150, 151-153, 166

customary, 4, 131, 133, 134, 137, 144, $159,164,165$

formal, 133, 134, 144

state, $21,129,131,137,140,144,160$, 166

Learning, 72, 194, 197, 199, 202, 203

Legal pluralism, 4, 6, 129, 130, 132, 133, $138,143,147,150,162,164$

Legal system(s), 150, 152, 157, 164 engaging, 129-144, 147, 149

Livelihoods, 20, 130, 150, 156, 173, 181, 184,188

Maasai, 60, 63-64, 67

Marble, 2, 3, 52, 63, 64, 67

Millennium Development Goals, 27, 38, 194

Mining, 3, 4, 25, 56, 61, 91, 95, 102, 103, $115,116,117-124,129-144$

Nationalisation, theory of, 3, 123-125

Natural resource, 1, 2, 13, 51, 91, 193

abundance, 6, 42, 43

definition, 53

endowments, 42-44

non-renewable, 57, 120

origin, $5,17,57$

point source, 43, 57

renewable, 19, 53, 57

rent, $24,36,38,42,43,44$

stage of development, 57

Neo-Malthusian approach, 13, 58

Palestinian Territory, 3, 5

Palk Bay, 155-158, 162, 163, 165

Participation, 19, 26, 36, 40, 41, 44, 99, $105,118,121,151,179,188$ 
Peace, 13, 15, 19-20, 22, 23, 28 negative, 36

Phronesis, 9

Policy, 8, 14, 17, 22-30, 72, 87, 96, 104, $160,161,162,164,185,194,195,198$, 199, 201, 202

Political, 3, 5, 6, 7, 9, 16, 19, 21, 27, 40, 43, $44,46,47,48,53,60,72,75,81-83$, $85,86,87,99,110,111,112,113,125$ ecology, 13, 148, 149, 150

interests, $81,82,83$

will, 81, 82, 83, 84

Poverty, 1, 14, 16, 18, 20, 22, 27, 37, 38, 46, $48,78,110,174,180,194$

Power, 3, 5-7, 20, 28, 39, 40, 46, 47, 54, 58, $63,65,66,68,74,76,79,81-83$, 93-94, 96-97, 99, 110, 112-113, 122-123, 125, 132, 144, 148-151, 154-155, 162-166, 182, 186

Privatisation, 21, 40, 113, 114, 115, 160, 163

Property

access and withdrawal, 114, 119

alienation, 114, 117

exclusion, 114, 117, 119

management, 114, 117

rights, 40, 56, 111, 113-114, 117, 122, 123,133

Prospect theory, 45

Rational choice, 38, 42, 47, 49

Research, 2, 8, 9, 21, 29, 30, 35, 71, 92, 97, 101, 102, 104, 184, 194, 196, 198, 199, 201, 202, 203

trans-disciplinary, 195, 198, 202

Resource abundance, 6, 14, 15, 16

curse, $6,14,15,43$

governance regimes, $14,28,29,74-75,86$

scarcity, 13-14, 16, 17, 18, 19, 20, 21, 26, $59,60,61$

variability, 21

wars, 17,18
Rights, 3, 21, 40, 56, 111, 113-114, 117, $122,123,133,134,135,137,138,139$, $141,143,144,157,159,161,164$ economic (social and cultural), 95, 99, 161 environmental, 97, 98, 100 human, 91-105, 137

water, 21, 72, 79

Scale, 16, 35, 51, 67, 86, 91

Science, 13, 14, 28-30, 93, 193, 202

Security, 35, 37, 40, 42, 82, 83, 93, 156, $163,175,180,182,183$

Social contract, 39-40, 43, 48

South Africa, 7, 59, 147, 148, 150, 153, 158-162, 164, 166

South Asia, 20, 73, 147, 148, 155-158, 166

Stakeholder involvement, see participation

States

autocratic, 3, 71, 83, 84

democratic, $3,71,83,84$

exclusive, $3,6,83,84,120$

fragile, 3, 27, 28, 73, 83, 84, 85

Suriname, 129, 130-131, 133, 134, 143, 144

Tools, 72, 80, 147, 195, 198, 202, 203

Trans-disciplinarity, see research, trans-disciplinary

Transparency, 23, 24, 25, 101, 179

United Nations, 15, 23, 26, 100, 137, 184

Violence, 36, 39, 40, 41-42, 46, 47, 60, 76, 96, 102

economies of, 15, 16-17

War, 15, 39

civil, 23, 35, 36, 37, 38, 42-44, 156

risk, 38, 40

World Bank, 16, 23-24, 38, 40, 87, 119, 120, 137

Yemen, 71, 77-81, 87 

Inhabitants of poor, rural areas in the Global South heavily depend on natural resources in their immediate vicinity. Conflicts over and exploitation of these resources - whether it is water, fish, wood fuel, minerals, or land - severely affect their livelihoods. The contributors to this volume leave behind the polarised debate, previously surrounding the relationship between natural resources and conflict, preferring a more nuanced approach that allows for multiple causes at various levels. The contributions cover a wide array of resources, geographical contexts (Africa, Asia and Latin America), and conflict dynamics. Most are of a comparative nature, exploring experiences of conflict as well as cooperation in multiple regions.

This volume finds its origin in an innovative research programme with the acronym CoCooN, steered by The Netherlands Organisation for Scientific Research (NWO/WOTRO) and involving universities and civil society partners in many countries. It presents the conceptual approaches adhered to by each of seven interdisciplinary projects, ranging from green criminology and political ecology to institutional analysis, legal pluralism and identity politics. The volume will be of interest to academics and practitioners concerned with an understanding of conflict as well as cooperation over natural resources. 